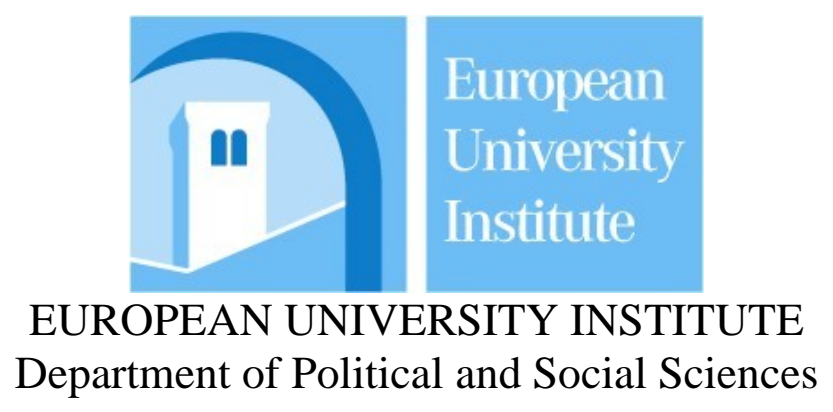

\title{
Statist Cosmopolitanism
}

\author{
Lea L. Ypi
}

Thesis submitted for assessment with a view to obtaining the degree of Doctor of Political and Social Sciences of the European University Institute

Florence, September 2008 


\title{
EUROPEAN UNIVERSITY INSTITUTE \\ Department of Political and Social Sciences
}

\section{Statist Cosmopolitanism}

\author{
Lea L. Ypi
}

Thesis submitted for assessment with a view to obtaining the degree of Doctor of the European University Institute

\section{Jury Members:}

Prof. Peter Wagner, Supervisor, University of Trent and former EUI

Prof. Robert E. Goodin, Australian National University

Prof. Wojciech Sadurski, European University Institute

Prof. Henry Shue, Oxford University

(C) 2008, Lea L. Ypi

No part of this thesis may be copied, reproduced or transmitted without prior permission of the author. 


\begin{abstract}
This research defends a particular version of cosmopolitanism: statist cosmopolitanism. Its point of departure is the current debate in international political theory on the moral standing of boundaries and the scope of distributive equality. Against existing cosmopolitan approaches, it is argued that states have an intrinsic normative standing and constitute the most relevant agents of global justice. Against non-cosmopolitan approaches, it is argued that the defence of compatriot favouritism in the distribution of egalitarian obligations rests on a confusion between motivation and principles in ethical reasoning. More positively, this research claims that the state is not only compatible with the cosmopolitan defence of distributive equality but also necessary for its realization.

The work is divided in three parts. The first part introduces some preliminary observations and illustrates the historical roots of the controversy between statism and cosmopolitanism with particular reference to the Enlightenment. The second part criticizes cosmopolitan and non-cosmopolitan approaches to global justice and defends both cosmopolitanism and the state. It illustrates how the limits of cosmopolitan and noncosmopolitan arguments are due to more fundamental methodological flaws, regarding the place of ideal and non-ideal considerations in normative theories of global justice. The third part reconciles the defence of cosmopolitanism with the defence of the state both at the level of principle and at the level of agency. At the level of principle, it shows how cosmopolitan egalitarian obligations to relieve relative deprivation may be grounded on sufficientarian responsibilities to relieve absolute deprivation. At the level of agency, it argues that those obligations ought to be understood politically - not just morally - and that states constitute the most relevant agents for their realization. Finally, the research clarifies how the transition from principles to agency could be made by local cosmopolitan "avant-gardes", responsible for acting within the state and thinking beyond it.
\end{abstract}




\section{Acknowledgments}

Even though this project was initially intended as a contribution to history of ideas hardly anyone reading the present work would doubt that it is firmly grounded in the tradition of analytical political philosophy. Although such an intellectual journey was not exactly planned from the start, if the transition turned out to be more enjoyable than expected, it is the merit of a number of friends and colleagues. I am particularly indebted to Christian Barry, Clara Brandi, Geoff Brennan, Eamonn Callan, Christine Chwaszcza, John Dryzek, Dimitris Efthimiou, Lina Eriksson, Katrin Flikschuh, Pablo

Gilabert, Bob Goodin, Gerhard Goehler, Patti Lenard, Raffaele Marchetti, Larry May, Sue Mendus, David Miller, Claus Offe, Teresa Pullano, Stefano Petrucciani, Wojciech Sadurski, Kim Scheppele, Nic Southwood, Bo Stråth, Christine Straehle, Tamara Jugov, Laura Valentini, Peter Wagner and Jonathan White, for commenting helpfully on different chapters of the thesis, for discussing ideas with me and for invaluable suggestions on how to improve the work as a whole.

Drafts of different chapters were presented to audiences at the European University Institute, The Australian National University (ANU), Princeton University, The London School of Economics, The Wissenschaftszentrum Berlin (WZB), The Wissenschaftskolleg (WIKO) Berlin, The University of Nottingham, and Essex University; I would like to thank participants at these events for their critical remarks and suggestions. The first draft was completed while holding a six-month fellowship from the Irmgard Coninx Stiftung at the WZB; special thanks go to Ingo and Sabine Richter, Sabine Berking and Leo Von Carlowitz for their friendship and generosity (as well as for indulging my attempts to defend "statist cosmopolitanism" in stilted German). A good part of the thesis was written during two visits to the ANU: I would like to thank the EUI department for sponsoring my travel the first time, and the staff and researchers at the Research School of Social Sciences, especially Bob Goodin, for making my stay incredibly pleasant and productive.

The years spent at the EUI have been the most difficult of my life, and those who know the reasons also know that writing the thesis was the easy part. What they 
may not be fully aware of is how this latter task was only made easy thanks to their efforts and support. There are two friends in particular who, in different ways, at different times, have played the most important role and to whom I am particularly indebted: Bob Goodin and Teresa Pullano. Had it not been for them, and for Jonathan White, this project would have never been brought to completion. I am also particularly grateful to Peter Wagner who, in addition to being an extremely supportive supervisor throughout these years, is perhaps unaware that he saved me from abandoning the doctoral programme halfway through. In addition, I would like to thank Giulia Albanese, Adrian Brisku, Paola Caputo, Renato Caputo, Donatella Della Porta, Brett Goodin, Ross Goodin, Ertol Muzina, Massimo Montelpari, Mario Reale, Paola Rodano, Françoise Thauvin, Ingela Walgrehn, as well as my wonderful friends at the "Collettivo di Villa Mirafiori" of the University of Rome La Sapienza for being on my side in times of great need. And I thank my mother and Lani for always reminding me that “one doesn't have just a thesis to worry about". Finally, I will never find enough words to say how very grateful I am to Jonathan for being there when the whole world seemed to be falling apart. Meeting him at the EUI on my third day there was without doubt the best thing that happened in the last few years.

Parts of Chapter I appear in "Sovereignty, cosmopolitanism and the ethics of European foreign policy", European Journal of Political Theory, vol. 7, (2008), 349364.

Parts of Chapter II appear in "Political membership in the contractarian defence of cosmopolitanism ", The Review of Politics, vol. 70, issue 3 (2008), pp. 442-472.

Parts of Chapter III appear in "Statist cosmopolitanism", The Journal of Political Philosophy, vol. 16, issue 1 (2008), pp. 48-71. 


\section{Contents}

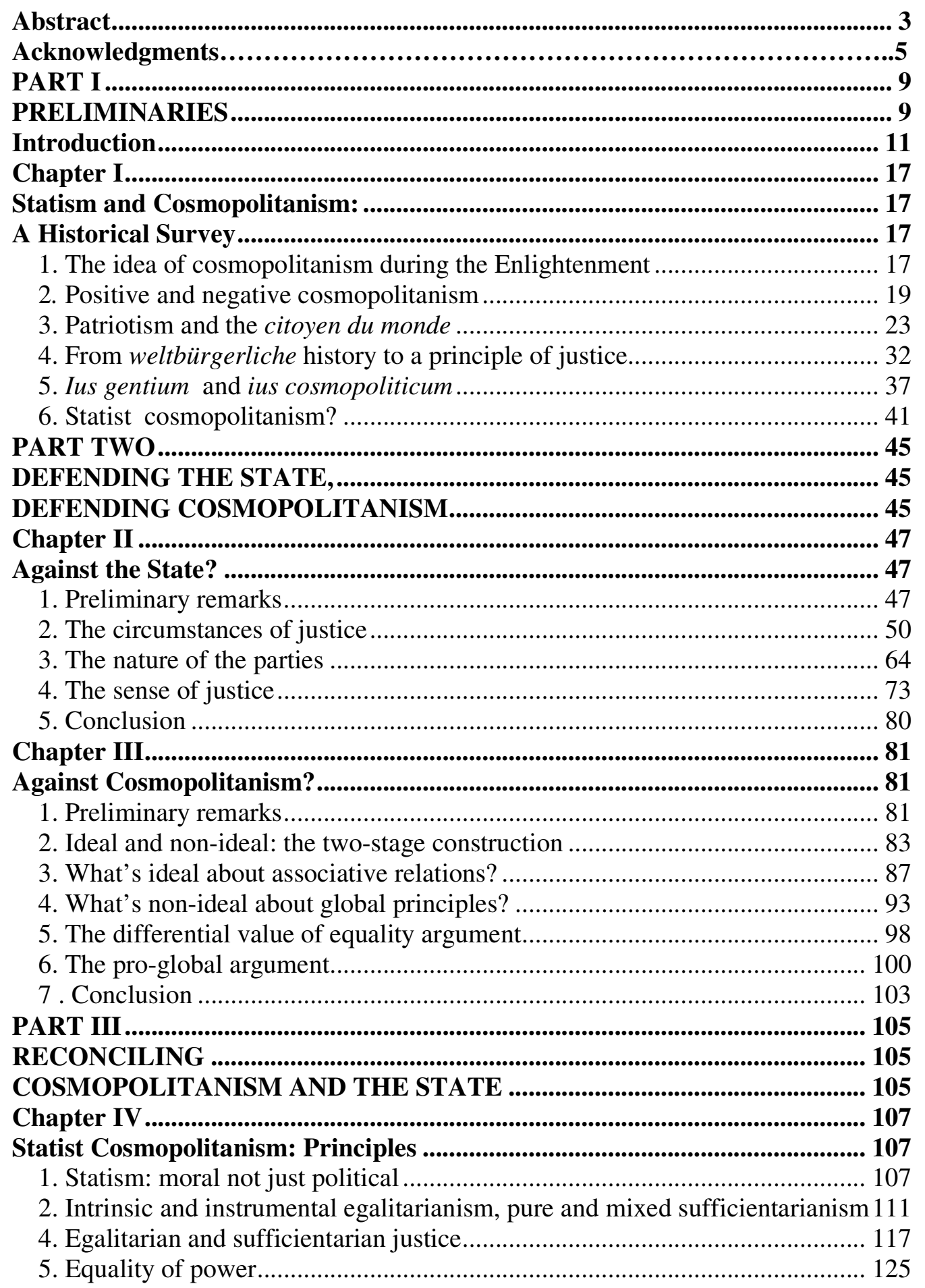




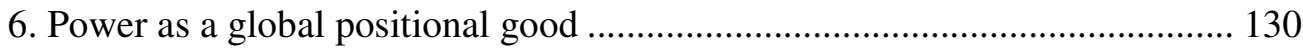

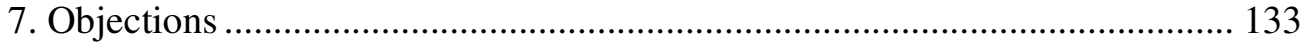

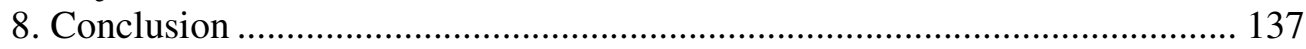

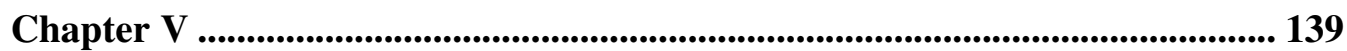

Statist Cosmopolitanism: Agency ........................................................................ 139

1. Cosmopolitanism: political not just moral ................................................ 139

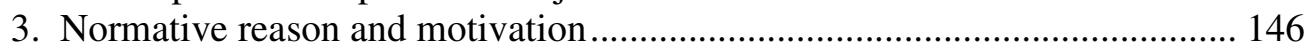

4. An alternative account of the political community ..................................... 151

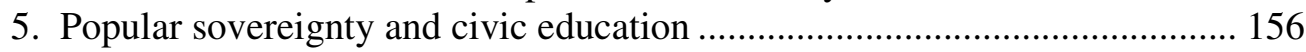

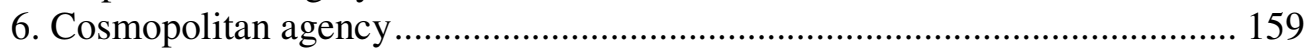

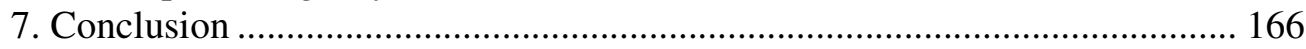

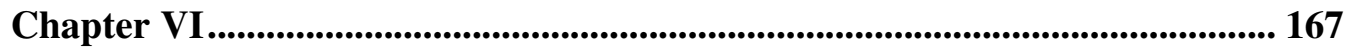

Statist Cosmopolitanism: .............................................................................................. 167

From Principles to Agency ......................................................................... 167

1. Politics as art: the idea of a cosmopolitan avant-garde................................. 167

2. The concept and its development: artistic avant-gardes ............................... 168

3. The analogy between art and politics (I): the public.................................... 175

4. The analogy between art and politics (II): actors....................................... 178

5. The meaning of a "cosmopolitan avant-garde" ......................................... 185

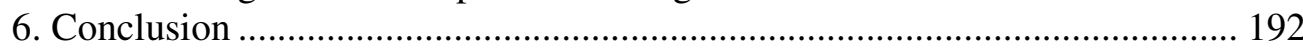

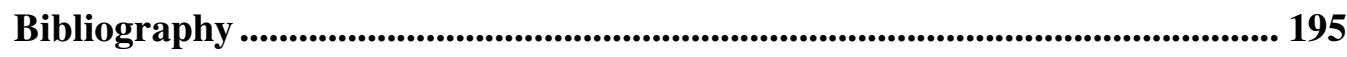




\section{PART I}

\section{PRELIMINARIES}




\section{Introduction}

Cosmopolitans think that states (and the political community underpinning them) hardly matter normatively. Non-cosmopolitans think that states matter so much that they override global distributive equality. Statist cosmopolitanism - the account this research tries to develop - argues that both the state and global distributive equality matter. States matter so much that without them global distributive equality would not be feasible. Global distributive equality matters so much that without it the partitioning of people into states would be morally indefensible.

Normative theory on global justice may be effective if it is able to reconcile moral desirability and political feasibility. This research takes as a point of departure the limits of both cosmopolitans and non-cosmopolitans to theorize effectively about global justice. To understand these limits we need to distinguish between claims of principle and claims of agency. Claims of principle tell us what we should do. Claims of agency tell us how we do what we do. Most cosmopolitan accounts focus on principles and neglect agency. Most non-cosmopolitan accounts focus on agency and derive principles from it. Statist cosmopolitanism attempts to say something about both principles and agency. With regard to principles, it tries to justify global distributive equality. With regard to agency, it tries to illustrate the normative relevance of the state.

An important tradition in political theory starts by taking people as they are and the laws as they can be. Contrary to that tradition, most cosmopolitans start with an ideal of how laws can be and overlook the way people are. Most non-cosmopolitans start with the reality of how people are and overlook how laws can be. Following that tradition, statist cosmopolitanism pays attention to people as they are and to the laws as they can be. It tries to defend a version of cosmopolitanism able to account both for the normative desirability of the cosmopolitan ideal and for its political feasibility and motivational sustainability.

What does "taking people as they are" mean? People vary from each other; they also vary from place to place and from time to time. Some worry only about themselves; some others about their family and friends; some consider only their fellow-nationals; some keep changing their mind. Yet others care about the world at large. I call the latter 
the cosmopolitan "avant-garde". The cosmopolitan avant-garde is both rooted and outward looking. It acts within the state, yet thinks beyond it. It talks to people as they are about how the laws can be.

How should laws be? Laws should protect individuals' life and guarantee the satisfaction of their basic needs. They should make sure that no one falls below a subsistence threshold and that every individual in the world has enough as is necessary for him to lead a minimally decent life. Both cosmopolitan and non-cosmopolitan accounts on global justice agree upon as much. Statist cosmopolitanism argues that if as much is agreed upon then (at the level of principle) much more than non-cosmopolitans are usually keen to grant follows. A concern for the relief of absolute deprivation at the individual level gives rise to a concern for the relief of relative deprivation at the level of states. On matters of principle, even if we start statists we might end up cosmopolitans.

If we take seriously global equality at the level of principle then (at the level of agency) much more than cosmopolitans have been prepared to discuss follows. We need to think about what sorts of obligations to place for relieving relative deprivation and about how such obligations could be feasibly and stably allocated. Statist cosmopolitanism argues that egalitarian obligations should be understood politically and not just morally. It further suggests that for political obligations to be effectively allocated we must acknowledge the primary role of states. On matters of agency, even if we start cosmopolitans we might end up statists.

The defence of statist cosmopolitanism is organized as follows:

Part One introduces some preliminary observations. More specifically:

Chapter I aims to reconstruct the historical roots of the controversy between those in favour of cosmopolitanism and those against it. It focuses in particular on the Enlightenment and illustrates how the tension between cosmopolitanism and statism during much of the $18^{\text {th }}$ century is due to the fact that the term "cosmopolitanism" initially only referred to an individualist moral attitude, that of the citizen of the world. A similar moral attitude was criticized for failing to combine the principle of equal treatment with an adequate conception of agency thereby cultivating citizens' indifference to the common good and leading to political passivity. A discussion of this issue is provided by analysing the writings of Voltaire and Rousseau and their reception 
in the thought of Immanuel Kant. It is only in the writings of Kant, I argue, that the defence of states at the level of agency supplements the defence of cosmopolitanism at the level of principle.

Part Two defends the state and cosmopolitanism. More specifically:

Chapter II takes a critical distance from existing cosmopolitan accounts which, contrary to Kant, try to ground the defence of global distributive equality on a critique of political membership. The chapter's task is brought into sharper focus by assessing the way in which global distributive obligations are usually justified in global contractarian theories. By focusing on the circumstances of global justice, the nature of the parties, the veil of ignorance and the sense of justice, the chapter shows how the cosmopolitan critique of political membership modifies the contractarian premises in a way that is both unwarranted and unnecessary. While failing to establish principles of global distributive justice, existing cosmopolitan adaptations ignoring the relevance of political membership simply weaken the method's justificatory potential.

Chapter III adds to the critique of existing cosmopolitan accounts, a critique of noncosmopolitan accounts. It argues that the limits of both approaches are due to more fundamental methodological flaws, namely, the misplacement of ideal and non-ideal considerations in their analysis of global justice. Non-cosmopolitans approach the nature of states by trying to show how special associative relations ground particular distributive obligations: they take people as they are but not laws as they can be. On the other hand cosmopolitans start with a justification of cosmopolitan principles but overlook the issue of agency: they take laws as they can be, but not people as they are. The chapter suggests that any adequate theory of justice should place ideal and non-ideal constraints at the appropriate level of analysis. It should start with ideal principles grounded on relevant circumstances of justice and from there move to the necessity of non-ideal agents sensitive to the political conditions of their realization.

Part Three reconciles the defence of the state and the defence of cosmopolitanism within an alternative approach to global justice: statist cosmopolitanism. More specifically: 
Chapter IV takes up the issue of principles. It defends an ideal of global distributive equality without endorsing usual cosmopolitan premises on the arbitrariness of political membership. It starts by clarifying the notions of absolute and relative deprivation as well as the conceptions of justice corresponding to each: sufficientarian justice and egalitarian justice. The chapter criticizes the sharp distinction usually drawn between such conceptions and argues that in specific circumstances of global justice both are conducive to principles for an equal distribution of relative shares. It further argues that the satisfaction of sufficientarian principles at the level of individuals gives rise to an egalitarian concern for the distribution of power at the level of states. The rest of the chapter articulates such statist egalitarian account of justice and defends the idea of equality of power against a number of objections.

Chapter $\mathbf{V}$ takes up the issue of agency. It argues that cosmopolitan obligations should be understood politically and not just morally and emphasizes the importance of nonideal associative relations for their allocation. The chapter stresses that cosmopolitan political obligations may be discharged when the institutional transformations they demand are both feasible and stable. Cosmopolitanism becomes a feasible option by taking advantage of political mechanisms that allow citizens to transform collective institutions by putting constraints on each other's actions. It may hope to be stably maintained by appealing to familiar associations, deeper social ties, cultural resources and mutual understandings that further motivate imperfect moral agents. The concepts of popular sovereignty and civic education are introduced to further clarify issues of feasibility and stability in the allocation of political obligations.

Chapter VI considers the link between principles and agency. It analyses more fully the issue of how states could be transformed in a way that promotes imperatives of cosmopolitan justice. It argues that there is no need to make heroic assumptions about what ordinary citizens may or may not be motivated to do when it comes to specific initiatives promoting cosmopolitan justice. It is enough to rely on those civic and political movements that are already morally or politically sensitive to issues of global poverty and power inequalities and argue that they may take the lead in promoting cosmopolitan imperatives. The chapter attempts to clarify this issue by introducing the notion of a "cosmopolitan avant-garde". It goes on to explore how one should understand the concept of an avant-garde movement, who constitutes it and how the civic initiatives 
of a cosmopolitan avant-garde might affect the rest of the citizen body thus gaining support for cosmopolitan transformations. 


\section{Chapter I}

\section{Statism and Cosmopolitanism:}

\section{A Historical Survey}

\section{The idea of cosmopolitanism during the Enlightenment}

"Un cosmopolite n'est pas un bon citoyen" - a cosmopolitan is not a good citizen. This is how in 1762, the fourth edition of the Dictionnaire of the French Academy commented on the concept of cosmopolitanism. In a more moderate, yet hardly unambiguous voice the Encyclopédie of Diderot and D'Alembert also remarked: “on se sert quelquefois de ce nom, en plaisantant, pour signifier un homme qui n'a pas de demeure fixe, ou bien un homme qui n'est étranger nulle part“. ${ }^{1}$ Both definitions provide a clear example of how, contrary to what is frequently assumed, the Enlightenment was as much the age of cosmopolitanism as of the adversity to it. $^{2}$

This chapter explores the historical roots of the controversy between statism and cosmopolitanism during the Enlightenment. ${ }^{3}$ After shortly clarifying the political and

\footnotetext{
1 "We sometimes use this term, in joking, in order to refer to a man who has no fixed residence, that is to say a man who is nowhere are stranger". Both definitions are cited in Georges Pieri, "Raison Et Cosmopolitisme Au XVIIIe Siècle," in L'idea Di Cosmopolitismo. Circolazione E Metamorfosi, ed. Lorenzo Bianchi (Naples: Liguori, 2002), 358.

2 The assumption is frequently made in normative studies emphasizing the roots of the cosmopolitan project in the philosophy of the Enlightenment, particularly the thought of Kant. See, for example, Martha Nussbaum, ed., For Love of One Country? (Boston: Beacon Press, 2002) 7-11, Onora O'Neill, Bounds of Justice (Cambridge: Cambridge University Press, 2000) 136-37, Kok-Chor Tan, Justice without Borders : Cosmopolitanism, Nationalism, and Patriotism (Cambridge: Cambridge University Press, 2004) 33-35, Jeremy Waldron, “What Is Cosmopolitan?,” Journal of Political Philosophy 8, no. 2 (2000): 236 ff. .

${ }^{3}$ For good historical overviews on the Enlightenment idea of cosmopolitanism and its tensions with patriotism, see Lorenzo Bianchi, ed., L'idea Di Cosmopolitismo. Circolazione E Metamorfosi (Naples: Liguori, 2002), Lorenzo Bianchi and Alberto Postigliola, eds., Un "Progetto Filosofico Della Modernità" (Naples: Liguori, 2000), Volker Gerhardt, Rolf-Peter Horstmann, and Ralph Schumacher, eds., Kant Und Die Berliner Aufklaerung. Akten Des IX. Internationalen Kant-Kongresses (Berlin: Walter de Gruyter, 2001), Pauline Kleingeld, "Six Varieties of Cosmopolitanism in Late Eighteenth-Century Germany," Journal of the History of Ideas 60, no. 3 (1999), Nicolao Merker, L'illuminismo in Germania. L'età Di
} 
intellectual context in which the terms "cosmopolite" and "citoyen du monde" started to re-circulate, the tensions between cosmopolitanism and patriotism are assessed. ${ }^{4}$ Focusing on the reflections of some key intellectual figures of the Enlightenment, the chapter argues that their disagreement on the normative justification of cosmopolitanism is due to an under-theorized link between cosmopolitan principles and cosmopolitan agency for most of the $18^{\text {th }}$ century.

In the first part of the chapter, I introduce two different ways of understanding the term "cosmopolitan" which circulated during the Enlightenment. The first is a negative one, associated to the attitude of private individuals who refuse allegiance to any kind of political community. The second is a positive one, associated to the attitude of the "sage" who makes his loyalty to a particular political community conditional upon its realization of a universal ideal of moral equality. The prevalence of either conceptualization produces an oscillation from a sceptic or even hostile evaluation of cosmopolitanism on the side of authors such as Voltaire or Rousseau to the enthusiastic endorsement of it by authors such as Leibniz and Diderot.

The second part of the chapter illustrates why in both the negative and positive understanding of cosmopolitanism the link between principles and agency remains under-theorized. By analysing the development of Rousseau's assessment of cosmopolitanism from the Discourses to The Social Contract, I try to show how cosmopolitanism fails to inspire a proper political project because it is considered either motivationally weak or politically dangerous. Cosmopolitanism represents either the attitude of the moral hero or that of the indifferent citizen; in any case, it is limited to a more or less commendable individual point of view, which fails to inspire a thorough reform of social institutions.

The third part of the chapter shows how the persistence of this problématique leads to a conceptual turn in Kant's political writings. By assessing the role of cosmopolitanism in Kant's philosophy of history and in his theory of right, I try to show how an abstract and ill-defined concept, as cosmopolitanism is by the middle of the $18^{\text {th }}$ century, acquires political prominence and full conceptual dignity. Kant is the first to reconcile patriotism and cosmopolitanism, principles and agency, a cosmopolitan idea of

Lessing (Rome: Editori Riuniti, 1989), Thomas J. Schlereth, The Cosmopolitan Ideal in Enlightenment Thought (Notre Dame: University of Notre Dame Press, 1977).

${ }^{4}$ Throughout this work I use the terms "state", "political community" and "polity" interchangeably. The exact definition of political community is provided in chapter V. By patriotism I mean, roughly, a principled allegiance to the state and to the political community underpinning it. 
equality and the normative standing of the state. Clarifying the historical relevance of Kant's statist-cosmopolitan approach to global justice introduces to the rest of this research where an ideal similar to the Kantian one is further defended from an analytical perspective.

\section{Positive and negative cosmopolitanism}

"When he was asked where he came from he would say: 'I am a citizen of the world'." Antiquity commentators (Greek and Latin) have invariably attributed the term kosmopolitēs to both Socrates and to Diogenes the Cynic. ${ }^{5}$ Yet the spirit in which either (if any of them) would have pronounced the sentence is rather different, and different were also the models they inspired during the Enlightenment.

The essence of Socrates' predicament was to teach people to think for themselves, a maxim that Kant would later transform in one of the founding principles of the Enlightenment. ${ }^{6}$ For Socrates, every human being was equally able of moral rectitude, regardless of where he came from. Cosmopolitanism represented a "positive" commitment, the attitude of a philosopher who believed in the universal force of reason and decided to put it at the service of moral virtue in both citizens and foreigners. Yet such cosmopolitanism did not undermine a firm political allegiance to native political institutions. Socrates was a good citizen (he had even risked his life during the first stage of the Peloponnesian war) and when arrested for not honouring local gods and corrupting young people, he refused to escape and submitted to execution. ${ }^{7}$

In the case of Diogenes the Cynic - a character that Plato allegedly called "Socrates gone mad" cosmopolitanism. Diogenes' assertion to be a citizen of the world expressed no positive commitment; he recognized no attachment to anyone in the world, refused to abide by

\footnotetext{
5 See Eric Brown, "Hellenistic Cosmopolitanism," in A Companion to Ancient Philosophy, ed. Mary Louise Gill; Pierre Pellegrin (Oxford: Blackwell, 2006), 549 , Derek Heater, World Citizenship and Government : Cosmopolitan Ideas in the History of Western Political Thought (New York: St. Martin's Press, 1996) 6-8.

${ }^{6}$ Immanuel Kant, “An Answer to the Question: What Is Enlightenment," in Practical Philosophy, ed. Mary J. Gregor (Cambridge: Cambridge University Press, [1784] 1996), 11.

${ }^{7}$ It must be noted that Socrates commitment to Athens was not unconditional. As Plato often makes clear, Socrates appreciated Athenian democracy and its requisite respect for free speech because he recognized that only where such values were politically realized did his teaching become at all possible. See Grg. 461e1-3; Apology 37c5-e2; Meno 80b4-7, in Plato, The Collected Dialogues of Plato Including the Letters, ed. Huntingon Cairns, Hamilton, Edith (Princeton: Princeton University Press, 1961 ).

${ }^{8}$ Brown, "Hellenistic Cosmopolitanism," 551.
} 
the polity's laws and dismissed conventional politics. Here the loyalty to the world [kosmos] instead of a particular polis was a merely negative statement, it did not correspond to any positive assumption of ethical responsibility extending to the cosmos the civic feelings of the polity. Diogenes considered living in harmony with the laws of nature the sole legitimate moral philosophy but he never attempted to teach a similar doctrine. While rejecting all positive obligations to friends, family or the polity, Diogenes' emphasis on being a "citizen of the world" was merely intended to deride the assumption of any civic responsibility.

Interestingly enough, both understandings of cosmopolitanism - the positive and the negative one - were revived during the Enlightenment. Throughout the $17^{\text {th }}$ and the $18^{\text {th }}$ century, Europe appeared dramatically torn by political conflicts determined by the clashes of particularistic religious, ethnic and political allegiances. A new world had started to emerge from the agony of medieval institutions, which, having lost legitimacy, exploited confessional hostility to ensure a contingent survival. The crisis of the Christian res publica, the emergence of Renaissance ideals and a renewed interest in the study of Greek and Latin texts understandably brought cosmopolitanism to the fore. The Socratic ideal appeared particularly apt for responding to the needs of a new age, promising as it did to maintain universal secularism and subjective autonomy, earthly solidarity and everyday tolerance. Yet, the negative meaning of cosmopolitanism was also employed by selfish and irreverent individuals, who declared to be citizens of the world only as a means of denying responsibility for any kind of political engagement.

Leibniz was among the first to refer implicitly to the Greek "positive" understanding of cosmopolitanism. "Justice", he claimed, is the virtue guiding affection to all human beings, "the Greeks call it philanthropy", it is "a charity of the sage who follows the decrees (dictata) of wisdom and the dictates of reason". 9 The exercise of justice should be considered unbound to national conventions and particular political circumstances because, he clarified, "as long as something of consequence can be done, I am indifferent on whether it is done in Germany or France, I only wish the good of the human race". ${ }^{10}$

\footnotetext{
${ }^{9}$ See his Codex Juris Gentium Diplomaticus (1694) in Gottfried Wilhelm Leibniz, Political Writings, ed. Patrick Riley (Cambridge: Cambridge University Press, 1988) 165-76. For a discussion of these issues, see André Robinet, "G. W. Leibniz: L'esprit Cosmopolitique Jusqu'à La Lettre,” ed. Lorenzo Bianchi (Naples: Liguori, 2002).

${ }^{10}$ Ibid.
} 
Leibniz interpreted this cosmopolitan "sense of justice" as a universal instinct of compassion, a sociable feeling found in every human being that the exercise of reason had the duty to bring into light when obscured by opposing conventions or by selfish inclinations. ${ }^{11}$ Yet he was sadly aware that the philanthropic attitude of single individuals was not enough for cosmopolitan projects to develop worldwide. One had to start from somewhere, seek support from this or that sovereign monarch, and construct relevant alliances. As he confessed to Peter the Great in 1712, while asking him to sponsor the project of an international Academy of Sciences, gathering researchers from all over Europe: "as long as I can find the means and occasions to contribute efficiently to the common good on all these subjects - and here I make no distinction between nations and parties - I would rather see the sciences brought to flourish in Russia than see them cultivated in mediocrity in Germany. The country where this project will go best, will be the one most dear to me, since the entire human race will profit from it and the real treasures will increase". 12

Leibniz's attitude was typical of several other philosophers throughout the Enlightenment. So Denis Diderot wrote to David Hume: "my dear David, you belong to all the nations of the earth and you never ask a man for his place of birth. I flatter myself that I am like you, a citizen of the great city of the world". ${ }^{13}$ Again, in introducing the term "citoyen du monde" in his Encyclopèdie, Diderot approvingly reported the Baron de Montesquieu's saying: "If I know of anything advantageous to my family but not to my country, I should try to forget it. If I knew of anything advantageous to my country which was prejudicial to Europe and to the human race, I should look upon it as a crime". ${ }^{14}$

This positive understanding of cosmopolitanism, which equated philosopher to citoyen $d u$ monde, rejected political chauvinism and praised universalistic patriotism, was by no means the only one to circulate during the Enlightenment. Towards the middle of the $18^{\text {th }}$ century it was being heavily counterweighted by a more negative conception, going back all the way to the model of Diogenes the Cynic and indeed employing the very Greek word with which Diogenes allegedly introduced himself. It is possible to find this second use of the term in the first $18^{\text {th }}$ century text where the term "cosmopolite"

\footnotetext{
${ }^{11}$ Gottfried Wilhelm Leibniz, New Essays on Human Understanding, ed. Peter Remnant and Jonathan Bennett (Cambridge: Cambridge University Press, [1704] 1996) I, 2,§ 4,12.

${ }^{12}$ Cited in Robinet, “G. W. Leibniz: L'esprit Cosmopolitique Jusqu'à La Lettre,” 12.

1322 February 1768, Correspondance, cited in Schlereth, The Cosmopolitan Ideal in Enlightenment Thought 1.

${ }^{14}$ Baron de Montesquieu, Pensées et fragments inédits, vol. 1, cited in Ibid. 47.
} 
explicitly appears for the first time. Indeed Louis-Charles Fougeret de Montbron - one of the lesser-known French men of letters of the $18^{\text {th }}$ century whom Diderot knew and despised - gave a rather unappealing definition of cosmopolitanism. ${ }^{15}$ In his autobiography Le Cosmopolite ou Citoyen du monde, which allegedly inspired Voltaire's Candide, he describes how he travelled everywhere without being committed to anyone because everything was indifferent to him:

Tout les pays me sont égaux pourvu que j'y jouisse en liberté de la clarté des cieux et que je puisse entretenir convenablement mon individu jusqu'à la fin de son terme. Maître absolu de mes volontés et souverainement indépendant, changeant de demeure, d'habitudes, de climat, selon mon caprice, je tiens a tout et ne tiens a rien. ${ }^{16}$

In a somewhat similar tone, Raynal's Histoire des deux Indes has a cosmopolitan merchant declare his intentions:

Périsse mon pays, périsse la contrée ou je commande, périssent les citoyens et l'étranger ... Tout les lieux de l'Univers me sont égaux. Lorsque j'aurais dévasté, sucé, extenué une région, il en restera toujours une autre où je pourrais porter mon or et en jouir en paix. ${ }^{17}$

The examples of Leibniz and Fougeret de Montbron clearly illustrate the double interpretation to which the cosmopolitan idea was subject over the course of the $18^{\text {th }}$ century. On the positive understanding, the concept appears morally strong but politically empty; it presents an admirable declaration of principles yet fails to be integrated by a positive conception of agency. Too weak to inform a concrete political vision, the best version of cosmopolitanism cultivated a mere academic fashion: the fashion of travellers, scientists, or writers whose communion of interests was embodied by that secular ecclesia called "république des lettres".

\footnotetext{
${ }^{15}$ See Gita May, "Le Cosmopolite Ou Le Citoyen Du Monde; La Capitale Des Gaules Ou La Nouvelle Babylone by Louis-Charles Fougeret De Monbron," The French Review 45, no. 3 (1972): 738.

16 "All the countries are the same to me as long as I can enjoy freely the clarity of the skies and comfortably entertain my own person until the end of its days. Absolute master or my will, and sovereign independent, changing place of residence, customs and climate according to my whim, I hold onto everything and hold onto nothing". See Fougeret de Montbron, Le Cosmopolite Ou Citoyen Du Monde, ed. Raymond Trousson (Paris: Ducros, [1750] 1970) 130. My translation.

17 "Let my country perish, let the county where I command perish too, let both citizens and strangers perish...All the places of the universe are the same to me. When I will have devastated, sucked, exhausted one region there will always be another where I could bring my gold and enjoy it in peace", see Guillaume-Thomas Raynal, Histoire Des Deux Indes (Paris: La Découverte, [1781] 1980) 70. My translation.
} 
On the other hand, the negative understanding of cosmopolitanism does not seem without political implications. Cosmopolitanism emerges here in dangerous opposition to any kind of patriotism and challenges individuals' loyalty to the civic body. It threatens an already fragile social bond; it encourages individual anarchy and social hypocrisy. It leads to a sceptic and rather libertine attitude, stressing how the citizen of the world is in fact nothing more than an ironic and dismissive character, swapping homeland institutions and changing country according to his whim.

Under no circumstances would the $18^{\text {th }}$ century philosophes - many of whom had put themselves at the service of enlightened monarchs - wish to be confused with these irreverent characters whose citizenship in the world turned out to be a sort of adventurous vagabondage and anarchical derision of the social order. Far from providing a remedy against selfishness and individualism, cosmopolitanism would in this case merely amplify those instincts. Therefore, if on one hand the potential contribution of moral cosmopolitanism was appreciated, its unqualified opposition to patriotism would rather be suspected. The concept maintained this ambiguity for most of the $18^{\text {th }}$ century until a new combination of principles and agency emerged from opposing considerations.

\section{$\underline{\text { 3. Patriotism and the citoyen du monde }}$}

Although Voltaire does not explicitly mention the term "cosmopolitanism", the concept is introduced in his Dictionnaire philosophique with reference to the entry "patrie" (homeland). As Voltaire defines it:

A homeland is made up of several families; and just as you normally stand by your family out of pride (amour propre), when there is no conflicting interest, because of the same pride, you support your town or your village, which you can call your homeland. ${ }^{18}$

Further down, the same point is made even more clearly:

We all want to be sure of being able to sleep in our own beds without someone else arrogating to himself the right to tell us to sleep elsewhere. Everybody wants to be sure of his wealth and his life. With everyone

18 François Marie Arouet Voltaire, Political Writings, trans. D. Williams (Cambridge: Cambridge University Press, [1752] 1994) 25-26. 
thus having the same desires, it works out that the private interest becomes the general interest: when we express our hopes for our selves, we are expressing them for the Republic. ${ }^{19}$

In sketching this Hobbesian hypothesis on the foundation of the state, Voltaire sounds hardly enthusiastic about the greatness of patriotic feelings. Only a natural instinct of self-protection and the need to preserve their own life, nurtures people's attachment to collectively framed political institutions. Individuals' motivation to support particular political communities is simply due to their amour propre. For Voltaire, as for Hobbes, the need for a socio-political aggregation leading to a civic union does not arise out of a common effort celebrating people's good will. On the contrary, if humans were naturally good they would not need to pay collective security at the price of individual liberty. They would not need a coercive force to suppress their natural instincts. Hence, the origin of political power does not suggest fraternity but potential aggressiveness; common decisions are not due to tolerance but to reciprocal fear; association is not imposed by solidarity but by uncontained egoism. Far from grounding political community on humanitarian values and cosmopolitan feelings, state institutions arise precisely to compensate for their absence.

It is clear that for Voltaire human beings do not transform their character by entering the civic sphere. Subordinating themselves to political institutions does not determine any qualitative transformation in people's natural instincts. They support their homeland in so far as they support themselves and they respect the community's bond in so far as this bond protects them from external threats. Such attitude marks no progress from a purely individualistic and interest-maximising attitude to something more authentic from a collective moral perspective. Not only do human beings never mature deeper social feelings towards their fellows, but also they may even actively harm them, if personal or national security is endangered. In the words of Voltaire:

It is sad that in order to be a good patriot one is very often the enemy of the rest of humankind. The elder Cato, that good citizen, always said when speaking in the senate: "That's what I think, and let Carthage go hang". To be a good patriot is to want one's city to prosper through trade and to be powerful through arms. Clearly, one country cannot win without any other losing, and it cannot conquer without making some people unhappy. ${ }^{20}$

\footnotetext{
${ }^{19}$ Ibid.

${ }^{20}$ Voltaire, Political Writings 25-26.
} 
Hence, individuals do not cure their natural egoism by being citizens of a political community. On the contrary, states might have an amplifying effect on their antagonistic impulses and exploit human ambition to serve their own competitive drive and will for power. "That is the human condition", stresses Voltaire, "to want your own country to be great is to wish your neighbours ill". ${ }^{21}$ The general interest arising by the shared goal of individuals to preserve their security, regains its particularity in serving the aggressive purposes of separate political communities.

Voltaire mentions the cosmopolitan spirit as a unique exception to this familiar trend: "The man who would want his homeland never to be larger, or smaller, or richer or poorer would be a citizen of the world". ${ }^{22}$ Yet he does not develop the issue further and it would be certainly wrong to suggest that Voltaire is here embracing the cosmopolitan viewpoint. The Dictionnaire philosophique does not go beyond a simple mention of the term "citoyen $d u$ monde" and an implicit appreciation for the allencompassing sense of justice that it embodies. This is because, in spite of his critical observations on amour propre as the main cause of rivalry among individuals and (by extension) among political communities, Voltaire did not consider it an obstacle to the enlightened progress of his age. In Voltaire's own interpretation of history, selfishness and the bourgeois search for profit play a positive role in encouraging the expansion of wealth and civilization. For him the age of Louis XIV was one of the most successful stages of human history since what really mattered were not greater freedom and the promotion of social justice, but military strength and the intensification of commerce and the $\operatorname{arts.}^{23}$

The same ambivalent evaluation of cosmopolitanism emerges very clearly in the writings of Rousseau, especially if we compare the use of the term in the Discours sur l'inegalité parmi les hommes and in Du contract social. The point of departure is however radically different from that of Voltaire. While the latter considered amour propre in society to arise out of a natural instinct of self-preservation, for Rousseau the parts are reverted: the egoistic character of bourgeois society generates all human evils and sets a limit to the development of an originally good nature. The role of history is also differently interpreted: in Voltaire the evolution of science and the arts constitute a measure of human progress whereas in Rousseau this very progress ultimately leads to

\footnotetext{
${ }^{21}$ Ibid.

22 Ibid.

${ }^{23}$ See François Marie Arouet Voltaire, Le Siecle De Louis Xiv (Paris Garnier-Flammarion, [1774] 1966).
} 
the triumph of luxury, to the corruption of mores and to what he calls society's "glittering misery". ${ }^{24}$

Voltaire particularly disliked Rousseau and ridiculed his Discourses as "the philosophy of a beggar who wished that the rich be robbed by the poor". ${ }^{25}$ However, it is interesting to notice that cosmopolitanism is mentioned in the Discourses in a context very similar to Voltaire's discussion of patriotism. Here Rousseau argues that even if one accepts that the artifice of the social contract may have temporarily contributed to establish a legal order and save people from the consequences of natural selfishness, contrasts have reappeared when the actors in the political scene ceased to be individuals and were replaced by states.

The Bodies Politic, he claims, thus remaining in the state of Nature among themselves soon experienced the inconveniences that had forced individuals to leave it, and this state became even more fatal among these great Bodies than it had previously been among the individuals who made them up. From it arose the National Wars, Battles, murders, reprisals that make Nature tremble and that shock reason, and all those horrible prejudices that rank among the virtues the horror of spilling human blood [...] more murders were committed in a single day's fighting, and more horrors at the capture of a single town than had been committed in the state of Nature for centuries together over the entire face of earth. ${ }^{26}$

The complaint of Rousseau is obviously on a very different level from Voltaire's. Yet, the context in which he mentions the cosmopolitan virtue of universal love for the entire humanity, as opposed to states' rivalry and will for power is interestingly the same. As Rousseau puts it,

Civil right having thus become the common rule of the Citizens, the Law of Nature no longer obtained except between different Societies where, under the name of Right of nations, it was tempered by a few tacit conventions in order to make commerce possible and to replace natural commiseration which, losing in the relations between one Society and another almost all the force it had in the relations between one man and another, lives on only in a few great Cosmopolitan Souls, who cross the imaginary boundaries

\footnotetext{
24 Jean Jacques Rousseau, The Discourses and Other Early Political Writings, trans. V. Gourevitch (Cambridge: Cambridge University Press, [1775] 1997) 175-80. It is interesting to notice how Kant makes use of the same term in discussing the role of civilization in his essay on universal history, see Immanuel Kant, "Idea for a Universal History with a Cosmopolitan Purpose," in Political Writings, ed. Hans Reiss (Cambridge: Cambridge University Press, [1784] 1991), 49.

${ }^{25}$ Cited in G. R. Havens, "Voltaire's Marginalia on the Pages of Rousseau," Ohio State University Studies 6, no. 15 (1933): 15.

${ }^{26}$ Rousseau, The Discourses and Other Early Political Writings 174.
} 
that separate Peoples and, following the example of the sovereign being that created them, embrace the whole of Mankind in their benevolence. ${ }^{27}$

For Rousseau the main virtue animating cosmopolitan characters is the social expression of a feeling people possess before entering into civil society: compassion. Such a feeling, that we also saw Leibniz mention, is one that:

Hobbes did not notice, and which - having been given to people in order under certain circumstances to soften the ferociousness of his amour propre or of the desire for self-preservation prior to the birth of amour propre - tempers his ardour for well-being with an innate repugnance to see his kind suffer. ${ }^{28}$

This feeling is so natural to human beings and this virtue is so universal and useful that even Mandeville, "'the most extreme detractor of human virtues", was forced to recognize it. Cosmopolitan souls are the only ones to preserve intact such an old natural virtue, threatened by the expanding corruption of human nature in civil society.

One would expect, given such a passionate praise of the moral purity of cosmopolitanism, to find it inspiring a new educative model or at the heart of a future political project aiming to overcome the state of nature among nations. Instead, nothing of this kind happens. Not only do these particular examples of compassionate characters hardly return in the following writings of Rousseau, but also if we insist on investigating the fate of such "great cosmopolitan souls" we will be surprised to notice a radically different approach. In the Geneva manuscript version of the Social contract Rousseau complains that cosmopolitans "boast of loving everyone" (tout le monde) so that "they might have the right to love no one". ${ }^{29}$ In Emile he goes even further, and recommends to "distrust those cosmopolitans who search out remote duties in their books and neglect those who lie nearest". 30

It is important to understand what motivates this shift in the interpretation of cosmopolitanism from the Discours sur l'inégalité parmi les hommes to Rousseau's later writings. If dedication to one's homeland means nothing more than amplified amour propre, why are characters once admired for their capacity to show compassion towards the others now considered some kind of impostors indifferent to any moral constraint?

\footnotetext{
${ }^{27}$ Ibid. 152.

${ }^{28}$ Ibid.

${ }^{29}$ Jean Jacques Rousseau, "Of the Social Contract," in The Social Contract and Other Later Political Writings, ed. Victor Gourevitch (Cambridge: Cambridge University Press, [1762] 1997), 158.

${ }^{30}$ Jean-Jacques Rousseau, Emile, trans. Barbara Foxley (Charleston: Biblio Bazaar, [1762] 2006) 14.
} 
Why has Rousseau decided to make a target of his critique the negative conception of cosmopolitanism rather than maintain the positive one he initially embraced? In order to answer this question, we need to focus on the different function that patriotism plays in Rousseau's successive political writings in light of his new interpretation of the origin and scope of the contractarian device.

In the Discourses on Inequality, the assessment of the state of nature and the critique that Rousseau moves to the social contract serve to condemn the unjust foundation of the civil order. Whatever the historical hypothesis on the origin of the social contract, Rousseau argues - contra Hobbes - that the civil union is unable to restore peace and preserve justice. The emergence of private property seems to constitute an insurmountable obstacle to an overall equal distribution of resources. ${ }^{31}$ The contractual union serves to merely legitimize an arbitrary process of acquisition started by the emergence of private property, and give it the appearance of a rightful action. Here, blind egoism and the unlimited ambitions of human beings cultivate the rule of the strongest and establish the power of some over that of many others. Society and its laws change a "skilful usurpation" into an "irrevocable right" and "for the profit of a few ambitious men" subject "the whole of Mankind to labour, servitude and misery". ${ }^{32}$ The state being grounded on a mere sum of individual interests and distorted by the same vices that amour propre generates, the anarchical dynamic of an egoistic, pre-civil condition can only be expected to escalate.

The question appears deeply transformed in the Social Contract. "Man is born free, and everywhere he is in chains. How did this change happen? I do not know. What can make it legitimate? I believe I can show it". "It is possible to notice, from the initial pages of the book, how the problem of an allegedly unjust initial distribution does not concern Rousseau anymore. Instead, his interest lies in the remedies that could be offered in order to morally justify the civil order. Returning to a state of nature in which human beings enjoyed peace and had infinite resources available does not appear a viable alternative. Civil society, whatever its limits might be, appears as the unique possible framework of coordination; political cooperation is the only means through which human selfishness and greed may be restrained.

\footnotetext{
31 "The first man who, having enclosed a piece of ground, to whom it occurred to say this is mine and found people sufficiently simple to believe him, was the true founder of civil society". Rousseau, The Discourses and Other Early Political Writings 164.

${ }^{32}$ Ibid. 173.

${ }^{33}$ Rousseau, "Of the Social Contract," 40.
} 
In the Social Contract, collective agreement is not analysed in the perspective of a historical hypothesis establishing the legacy of unjust acquisition or marking the origin of institutionalized corruption. It is transformed into a regulative idea concerning the unique social mechanism of which human beings dispose in order to resolve social conflict. The complete alienation of individual freedom leads to a collective exercise of popular sovereignty whereas the mutual obligation of obedience is tempered through civic education. ${ }^{34}$ The social contract does not merely re-propose a sum of singular individual wills (volontè de tous) but qualitatively transforms this common force into a unitary entity capable of serving the impartial good of the community (volonté générale). Society cannot be rescued through the efforts of a single moral agent, who may always, as such, indulge his selfish inclinations. It is the dynamics of the union of all, and the kind of obligation this generates, which establish the possibility of overcoming the particular interests of the pre-political man (of the bourgeois) in a rational determination of interests carried out by the same subject as a citoyen.

Popular sovereignty and civic education confer to the Rousseauean theory of the state a special normative standing. Its ethical strength derives from the collective participation in democratic practices that arise not just because of the common recognition of mutual normative constraints. As Montesquieu had already emphasized, the efficiency of laws and exercise of solidarity is also tightly bound to the uses and mores of a particular political community, to its historical development, major virtues and dominant vices. Rousseau emphasizes this point in one of the most important parts of the Social contract: "morals, customs, and above all opinion" constitute the secret attendance of a great legislator "while he appears to restrict himself to particular regulations which are but the ribs of the arch of which morals, slower to arise, in the end form the immovable Keystone". 35

Rousseau therefore agrees with the Hobbesian account that no individual moral will could ground the social contract, if the latter is understood merely as a historical hypothesis on the origin of political union. This does not imply, however, renouncing the regulative idea that a community of people and their collective effort to uphold a particular civic order may also promote an ethical goal: developing the common good in a disinterested way. Of course, politics does not arise out of morally good intentions but to compensate for their absence. However, if the general will historically succeeds in

\footnotetext{
${ }^{34}$ I will return to both issues in chapter $\mathrm{V}$.

${ }^{35}$ Rousseau, "Of the Social Contract," 81.
} 
limiting the arrogant emergence of particularism, associative political duties may also become a means through which the scope of the polity is further extended.

Similar considerations on the function of the social contract and the relationship between individual and political community, singular and universal, led Rousseau to a different evaluation of cosmopolitanism. It is now easier to understand why, in his later writings, cosmopolitanism is considered only negatively and identified with the attitude of single individuals who dismiss that civic essential bond though which moral obligations are discharged. The model of a non-interested community of moral persons cannot be embodied by the solipsistic attitude of individual human beings and their perhaps sincere but nonetheless contingent feelings of solidarity. Natural compassion cannot substitute political activism. What modern society needs is not promoting compassion but reinforcing justice, and the good faith of single individuals simply does not seem enough when a collective effort addressing the whole political order is required. As long as the citoyen $d u$ monde claims to overcome with his all-encompassing humanistic feelings particular political boundaries, he is essentially placing himself outside the moral and political context where the general will is expressed, at best risking to reduce his active commitment in favour of common political obligations, at worst threatening the fragile constitutive balance of the collective association.

Rousseau's observations invite one to seek a solution to the outburst of injustice and arbitrariness within the power-relations and political-institutional context upon which the general will is grounded. The Social Contract however leaves essentially unanswered the further question of anarchy in the international sphere that Rousseau's Discourses on inequality had raised. This issue becomes extremely relevant if one focuses on Rousseau's theory of the general will and considers the possibility that it may be precisely the collective interest of one particular community to nurture hostility and competition towards individuals belonging to other political groups. Would it be possible to expand the borders of the polity and to encompass every individual considered simply as member of the human community? More specifically, is it possible to reconcile cosmopolitanism and the states' "general will"?

Although Rousseau does not raise these questions in the Social Contract, he comments extensively on them in the following writings, especially the ones concerning the project of perpetual peace of the Abbé de Saint Pierre. If the social order, he claims, 
were really, as it is pretended, the work not of passion but of reason, should we have been so slow to see that, in the shaping of it, either too much, or too little has been done for our happiness? That each one being in the civil state as regards our fellow-citizens but in the state of nature as regards the rest of the world, we have taken all kinds of precautions against private wars only to kindle national wars a thousand times more terrible? And that, in joining a particular group of men, we have declared ourselves enemies of the whole race? ${ }^{36}$

In the following pages of this essay Rousseau seems to support the idea that the only rational alternative to the precarious principle of balance between powers is extending to the international order the principles of civil coexistence present in the nation-state. He defends Saint Pierre's proposal for a European political federation which, although not requiring states to renounce their national sovereignty, aims to preserve their internal security by means of collective agreement on matters of common interest. As Rousseau puts it,

if there is any way of reconciling these dangerous contradictions, it is to be found only in such a form of federal government as shall unite nations by bonds similar to those which already unite their individuals members, and place the one no less than the other under the authority of the law. ${ }^{37}$

One can easily note how - despite the relevance of a federative project for promoting perpetual peace - the constituent parts of this association are not individuals but states. In fact, the creation of a political community capable of overcoming the state of nature between states does not express the general will of individuals as members of an international community but the common interests of their states. However, the realistic tone assumed by the Rousseauean discussion suggests that the project for a future European federation is not guided by moral principles and good intentions but by a purely rational calculation founded on states' utility maximisation. ${ }^{38}$ Here the need to reach an agreement on the organization of international affairs does not undermine the normative standing of particular political communities. On the contrary, precisely

\footnotetext{
36 Jean Jacques Rousseau, "Abstract and Judgement of Saint Pierre's Project of Perpetual Peace," in Rousseau on International Relations, ed. S. Hoffman; D. Fidler (Oxford: Clarendon Press, [1756] 1991), 54.

${ }^{37}$ Ibid.

38 "Everyone can see that what unites any form of society is a community of interests, and what disintegrates it is their conflict", Rousseau claims. This is why "as soon as society is founded, some coercive power must be provided to co-ordinate the actions of its members". Rousseau, "Abstract and Judgement of Saint Pierre's Project of Perpetual Peace," 61.
} 
because they constitute legitimate authorities, embodying peoples' general will, no superior tribunal is allowed to judge the moral legitimacy of their interests.

There are good reasons to remain sceptic of states, judged from this egoistic and interest-based perspective. Yet, as we have seen, there are also good reasons to suspect the cosmopolitan individualist attitude, especially its dangerous oscillation between moral flamboyance and political aridity. Is there a way of combining the positive meaning of cosmopolitanism with the normative relevance of the state? This is the question inspiring the Kantian reflection on global justice.

\section{From weltbürgerliche history to a principle of justice}

It is only in the work of Immanuel Kant that the shift from an individual conception of cosmopolitanism (understood either as a moral utopia or as a dangerous anti-patriotic sentiment) to a principle of global justice becomes fully comprehensible. In order to understand this shift, which seems strongly influenced by Rousseau's analysis of the concept, it is important to consider closely Kant's essay: Idea for a universal history from a cosmopolitan purpose, published in 1784. The very title of the essay, and the fact that cosmopolitanism is linked to a "purpose" (Absicht) orienting the historical interpretation of world-events, already reveals two Kantian innovations in the analytical understanding of the concept. The first one is related to the fact that Kant seems to have isolated the term from its Cynic individualist meaning, in order to make it a category for understanding the collective progress of the human species (Menschengattung). The second innovation points at the inclusion of the antinomy egoism-cosmopolitanism in a theoretical approach that combines politics and morality within a teleological account of history. Let us consider both more in depth.

Like Rousseau, Kant starts from the problematique of the anarchical condition of the international scene and focuses on the regulative function of collectively exercised power. However, Kant does not limit the moral scope of the social contract to particular political boundaries. "What is the use of working for a law-governed civil constitution among individual men, i.e., of planning a commonwealth?" he asks. "The same unsociability which forced men to do so gives rise in turn to a situation whereby each commonwealth, in its external relations (i.e., as a state in relation to other states), is in a position of unrestricted freedom. Each must accordingly expect from any other precisely 
the same evils which formerly oppressed individual men and forced them into a lawgoverned civil state". 39

Kant's theory of history seems to share the early-Rousseauean view that the development of civilization does not necessarily lead to that of morally good intentions. However, his essay on universal history brings forward a teleological conception in which antagonism among human beings is considered a "means" through which the need for a law-governed social order arises. As Kant puts it,

the first true steps are taken from barbarism to culture, which in fact consists in the social worthiness of man. All men's talents are now gradually developed, his taste cultivated, and by a continued process of enlightenment, a beginning is made towards establishing a way of thinking which can with time transform the primitive capacity for moral discrimination into definite practical principles; and thus a pathologically enforced social union is transformed into a moral whole. ${ }^{40}$

Egoistic feelings therefore promote people's disposition to sociability and then to an authentic moral spirit. From an initial stage of antagonism, characterized by the emergence of aggressive instincts of self-protection, a kind of calculating rationality, utilitarian in scope, emerges. According to Kant, one is not entirely free insofar as practical action is oriented by selfish interest. However, decision-making at this stage is also not entirely determined by natural instincts, given that people are still able to calculate their advantages and rationally choose among different options. Such an attitude is distinctive of that historical age of human development in which man is divided between the realm of nature and that of freedom and in which egoism is associated with a capacity of choice unknown to animals, although not fully developed.

Therefore, Kant shares with Voltaire and with the Rousseauean Discourses the idea that the development of antagonism constitutes a crucial moment to understand the passage from nature to civil society. Moreover, he shares the idea of the Social contract whereby the unilateral, interested, egoistic origin of the social union does not preclude its future promotion of morally good intentions, in Rousseauean terms: of the general will. For Kant, as for Rousseau, this can only happen through a common effort to attain "civil society which can administer justice universally". "However, if the revaluation of the antagonistic moment, of this "unsocial sociability" among men seems enormously

\footnotetext{
${ }^{39}$ Kant, "Idea for a Universal History with a Cosmopolitan Purpose," 47.

${ }^{40}$ Ibid., 44.

${ }^{41}$ Ibid., 45.
} 
helpful to understand the exit from the state of nature and the formalisation of the ethical, utilitarian instances, this does not seem to be enough. There is another question emerging as soon as we consider the social contract not as a mere historical hypothesis (in the sense of the Discourses) but as an idea of reason (in the sense of the Social contract).

In the latter case it is important to bear in mind that the development of morally good intentions is not only threatened by individual antagonism but also by the anarchy of international society, by war and by states' expanding ambition for power. Hence, Kant says, until the spirit of mediation and the collective effort in promoting "united power" and "deliberation according to laws of a unified will" will be able to guarantee peace and develop freedom for all human beings, history shall be marked by stages of destruction and progress, with this fragile balance always threatening unconditioned obedience to rational moral imperatives.

Here the Kantian project starts to emerge clearly, developed further in his essay on Perpetual Peace and in the Doctrine of Right. It is related to the planning of a "great political body of the future" which,

although it exists for the present only in the roughest of outlines, nonetheless seems as if feeling to stir in all its members, each of which has an interest in maintaining the whole. And this encourages the hope that, after many revolutions, with all their transforming effects, the highest purpose of nature, a universal cosmopolitan existence, will at last be realised as the matrix within which all the original capacities of the human race may develop. ${ }^{42}$

This is precisely the point in which the cosmopolitan concept, defined in Leibniz, Voltaire and Rousseau as part of an ethical doctrine referring to the attitude of single individuals who think of themselves as citizens of the world, starts changing its original meaning. Cosmopolitanism ceases to be associated to abstract sentiments of love for humanity and a vague sense of justice and requires instead "entering a federation of peoples" in which every state may obtain security "not from its own power or its own legal judgement", but only from "a united power and the law-governed decisions of a united will". 43

Interpreters usually converge on the opinion that in the development of his thought from the Idea for a universal history to the Doctrine of right Kant may have progressively abandoned this original idea of a single political body with coercive

\footnotetext{
${ }^{42}$ Ibid., 51.

${ }^{43}$ Ibid.
} 
powers in favour of a less demanding but pragmatically more appealing project of a voluntary association of states. An ongoing scholarly debate focuses on the reasons motivating Kant's oscillation from the former to the latter thus raising the question of the enforcement capacities of a free league of states. ${ }^{44}$ However, the difference between the 1784 essay and Kant's later political writings may not lie in the modification of the substantive proposal but rather in the systematic role of the principles of cosmopolitanism and in the different conceptualization of the agents required for their promotion. $^{45}$

Indeed, in Idee zu einer allgeimener Geschichte cosmopolitanism constitutes a mere point of view from which to interpret the antagonistic development of human interactions in light of a teleological understanding of universal history. In the writings after the French Revolution, this proposal acquires a specific political meaning whose "objective reality" may be proved by the realization of republican ideals in a "powerful and enlightened people" the constitution of which inevitably promotes the highest political good, i.e. perpetual peace. ${ }^{46}$ In the Doctrine of right the ius cosmopoliticum is distinguished by both the rights of citizens within a state (ius civitatis) and the right of nations (ius gentium) and stands as a separate systematic category regulating the conditions of interaction among citizens of different states or citizens and strangers. ${ }^{47}$

\footnotetext{
${ }^{44}$ For Otfried Hoeffe those are pragmatic reasons, see Otfried Hoeffe, Kant's Cosmopolitan Theory (Cambridge: Cambridge University Press, 2006) 189-203.; Howard Williams, Georg Cavallar and Pauline Kleingeld argue for a kind of dialectic mediation between normative and empirical requirements, see Georg Cavallar, The Rights of Strangers. Theories of International Hospitality, the Global Community and Political Justice since Victoria. (Aldershot: Ashgate, 2002) 323-49, Pauline Kleingeld, "Kant's Cosmopolitan Law: World Citizenship for a Global Order," Kantian Review 2 (1998): 72-90, Howard Williams, Kant's Political Philosophy (Oxford: Blackwell, 1983) 253-60. whereas Katrin Flikschuh considers the problem irresolvable within the normative discourse of Kant's Doctrine of Right, see her Katrin Flikschuh, "Justice or Virtue? Kant's Problem of "International Right"," (2006)., unpublished conference paper.

${ }^{45}$ Otfried Hoeffe and Pauline Kleingeld argue for a much more significant shift, see Otfried Hoeffe, ed., Zum Ewigen Frieden (Berlin: Akademie Verlag, 1995) 109-32. and Pauline Kleingeld, "Kant's Cosmopolitan Patriotism," Kant Studien 94, no. 3 (2003): 301. However, in both his essay on universal history and in the Doctrine of Right Kant uses the Latin term "Foedus Amphictyonum" to refer to the kind of political organization that would be required to exit the anarchical order of the international sphere. Kant rarely uses Latin for arbitrary reasons in his writings. Thus the specific reference to the Amphytionic league - the voluntary association for the preservation of peace among Greek city states - may be an evidence of the fact that the type of political body he has in mind in both the Idea for universal history and his later essays has not changed. See Immanuel Kant, "Idea for a Universal History in Cosmopolitan Perspective," ed. H. B. Nisbet (Cambridge: Cambridge University Press, [1784] 1991), 47, Immanuel Kant, "The Metaphysics of Morals," in Practical Philosophy, ed. Mary Gregor (Cambridge: Cambridge University Press, [1797] 1996), 483.

${ }^{46}$ Immanuel Kant, "Toward Perpetual Peace," in Practical Philosophy, ed. Mary Gregor (Cambridge: Cambridge University Press, [1795] 1996), 327.

${ }^{47}$ Kant, "The Metaphysics of Morals," 489-90.
} 
The evolution of the term's significance becomes clearer if we consider the association cosmopolitanism-philanthropy, as it appears in On the common saying: 'This may be true in theory but it does not apply in practice', in Perpetual peace and in the Doctrine of right. In the first case, Kant understands cosmopolitanism in exactly the same way as Leibniz: a "universally philanthropic attitude" inspiring the regulative idea of a collective political organization upon which to ground the right of nations. However, in Perpetual peace, Kant seems to have abandoned this individualist conception of cosmopolitanism. In striking contrast with Leibniz's view, he argues here: “it is not a question of philanthropy but of right". ${ }^{48}$ Along similar lines, the opening section on cosmopolitanism in the Doctrine of right declares that the rational idea of a "peaceful, even if not friendly, thoroughgoing community of all nations on the earth that can come into relations affecting one another is not a philanthropic (ethical) principle but a principle having to do with rights". 49

The solution to the question of the state of nature in the international domain is investigated here in the spirit of The Social contract where rights, instead of being affirmed through morality, provide the condition of possibility for its further development. By breaking with philanthropy, cosmopolitanism constitutes the regulative ideal of a political project combining principles and agency. This is achieved by proposing a form of statist cosmopolitanism, a project where republican states interact with one another while internally promoting freedom, equality and independence. ${ }^{50}$ The conflict between cosmopolitanism and patriotism is thereby resolved not by opposing the former to the latter but by rendering the cosmopolitan union an internal political end of sovereign states. ${ }^{51}$

\footnotetext{
${ }^{48}$ Kant, "Toward Perpetual Peace," 328.

${ }^{49}$ Kant, "The Metaphysics of Morals," 489.

${ }^{50}$ See Immanuel Kant, "On the Common Saying: That May Be Correct in Theory, but Is of No Use in Practice," in Practical Philosophy, ed. Mary Gregor (Cambridge: Cambridge University Press, [1793] 1996), 291. Interestingly enough in the preparatory notes for the writing, Kant associates the two ideas with the concept of cosmopolitan unity, which presupposes independence without a contract. This issue is discussed in more detail in Howard Williams, Kant's Critique of Hobbes (Cardiff: University of Wales Press, 2003) 129-59., who also clarifies the systematic link between cosmopolitanism and republicanism in light of Kant's theory of political obligation.

${ }^{51}$ See Kant's remarks on patriotism in Kant, "On the Common Saying: That May Be Correct in Theory, but Is of No Use in Practice," 294-5. and Kant, “Toward Perpetual Peace," 322-5.
} 


\section{$\underline{\text { 5. Ius gentium and ius cosmopoliticum }}$}

The reflections above lead precisely to what Rousseau, in his observations on Saint Pierre's project for peace, had failed to provide. Analogously to Rousseau, Kant grounds political obligation on the dialectic between the distributive will of all and the collective general will. However, he does so in a broader perspective whereby the ius cosmopoliticum is systematically derived by both domestic and international public right.

The Metaphysics of morals contributes significantly to clarify the meaning of this passage. In the Doctrine of right the category of "public right" introduces the necessity of a sum of laws regulating the conditions of interaction among human beings both taken as single individuals and as members of constituted political units. Since "they all affect one another", Kant claims here, "a rightful condition under a will uniting them", is needed. ${ }^{52}$

From here it is possible to consider more in detail the necessity and systematic challenges faced by the conceptualization of cosmopolitan right (ius cosmopoliticum) as distinctive from and related to the right of states (ius gentium). Both ius cosmopoliticum and ius gentium appear normatively desirable to put an end to the anarchy of the international sphere where states, "like lawless savages" are in a "non-rightful condition" ${ }^{53}$ However, Kant specifies the limits of the analogy by clarifying the diversity of agents operating in the domestic and in the international sphere. International right involves "not only the relation of one state toward another as a whole, but also the relation of individual persons of one state toward the individuals of another, as well as toward another state as a whole". ${ }^{4}$

The implications of such distinction are clarified in further detail in the section on Cosmopolitan right, immediately following the discussion on the right of nations and the conditions of war and peace between sovereign states. The specificity and allencompassing relevance of cosmopolitan right is deduced by the global extension and reciprocal influence of interactions among people: "all stand originally in a community of land". 55 This is, as Kant clarifies, a "community of possible physical interaction (commercium)" in which each member may offer "to engage in commerce with any other, and each has the right to make this attempt without the other being authorized to

\footnotetext{
${ }^{52}$ Kant, "The Metaphysics of Morals," 455.

${ }^{53}$ Ibid., 482.

${ }^{54}$ Ibid.

${ }^{55}$ Ibid.
} 
behave toward it as an enemy because it has made this attempt". ${ }^{56}$ However, it is important to notice how the only category of right that recognizes the status of individuals, as such, amounts to a mere "attempt to try to establish community with all and, to this end, to visit all regions of the earth". ${ }^{57}$

Cosmopolitanism does not therefore replace statism. It does not cancel the right of states to territorial integrity and autonomous decision-making, even when the goal is to ensure that "crude peoples will become civilized" 58 (or to promote human rights - one would be tempted to say in modern jargon). Cosmopolitanism integrates traditional conceptions of ius gentium with a political duty to facilitate non-exploitative forms of exchange (including trade) between states - a constraint that goes alongside with a powerful critique to colonialism and foreign intervention. ${ }^{59}$ Far from establishing the normative superiority of individuals over states, cosmopolitan right protects organized territorial entities from the violent or manipulative moves of powerful countries. Indeed, Kant claims that even when the goal is that of obtaining consent to sign a contract, such contract should not "take advantage of the ignorance of those inhabitants". ${ }^{60}$ But how could one take seriously cosmopolitan right in the absence of a positive agent realizing its principles, critics ask?

This is where the prospect of a just framework for regulating interactions among sovereign states becomes crucial for the analytical understanding of cosmopolitanism. Kant alludes to it in the very definition of the concept: "this right, since it has to do with the possible union of all nations with a view to certain universal laws for their possible commerce, can be called cosmopolitan right (ius cosmopoliticum). ${ }^{61}$ As it is clear from those passages, although recognizing the intrinsic validity and trans-national sphere of application of individual claims, political agency is linked to the capacity of cooperation and to the collective will of each sovereign state.

\footnotetext{
${ }^{56}$ Ibid. Unfortunately I cannot discuss in more detail the justification of cosmopolitan right derived from the global extension of interactions among individuals but only mention that it may be linked to the broader "relational" requirement of Kant's metaphysics of right. An excellent discussion of this issue is provided in Flikschuh, “Justice or Virtue? Kant's Problem of “International Right”.” Pauline Kleingeld has also focused on the justification of a cosmopolitan right by linking it to Kant's innate right to freedom, see Kleingeld, "Kant's Cosmopolitan Law: World Citizenship for a Global Order,” 78-79.

${ }^{57}$ Kant, "The Metaphysics of Morals," 489.

${ }^{58}$ Ibid., 490.

${ }^{59}$ Ibid. I discuss further the issue of cosmopolitan principles facilitating non-exploitative international trade in chapter IV.

${ }^{60}$ Ibid.

${ }^{61}$ Kant, "The Metaphysics of Morals," 489.
} 
Kant's scepticism towards the creation of a unitary political body with coercive powers is not due to concerns on the empirical feasibility of the project, as it might superficially appear from a hastened reading of The doctrine of right. ${ }^{62}$ Instead, it is consistent with two strong arguments by virtue of which the analogy between individual and state anarchy in the international sphere ultimately collapses.

The first one refers to Kant's remarks on the undesirability of a sovereign enforcer of cosmopolitan justice. In The doctrine of right he emphasizes that a single political body, globally extended and with coercive powers, would be impossible to govern, might soon degenerate into despotism and establish an irreversible anarchy. ${ }^{63}$ In Toward perpetual peace he comments on this issue with an observation which reminds very much of Rousseau's discussion on patriotism in The social contract. Rousseau noticed here that "the more the social bond stretches, the looser it grows" and Kant seems to quote this passage implicitly when he emphasizes that "as the range of government expands laws progressively loose their vigour". ${ }^{4}$ As Rousseau had emphasized, unlimited territorial extension would undermine patriotism by turning citizens into strangers who share nothing but a coercively imposed allegiance to laws. Without popular sovereignty being integrated by civic education, without a substantive ethical bond and laws designed to reflect the spirit of a people, the general will would be corrupted by the emergence of selfish particularism and political institutions would lack motivational stability. For Kant too, the diversity of cultures and religions - even if it may initially give rise to conflict - allows for a "gradual approach of human beings to greater agreement in principles". ${ }^{65}$ Cosmopolitanism is in this case "produced and secured" not merely through the coercive use of forces but "by means of their equilibrium in the liveliest competition". 66

The second argument relates to Kant's explicit emphasis of the difference between the anarchical condition of individuals in the domestic sphere and that of states in the international one. As he clarifies, "such a state of affairs cannot be pronounced completely unjust since it allows each party to act as a judge in its own cause". In fact states, intended in the Rousseauean sense of political communities, do not face the same

\footnotetext{
${ }^{62}$ This "pragmatic" argument is made by Hoeffe, Kant's Cosmopolitan Theory 189-203.

${ }^{63}$ Kant, "The Metaphysics of Morals," 487.

${ }^{64}$ Jean Jacques Rousseau, "Considerations on the Government of Poland," in The Social Contract and Other Later Political Writings, ed. Victor Gourevitch (Cambridge: Cambridge University Press, [1772] 1997), 113. Kant, "The Metaphysics of Morals," 336.

${ }^{65}$ Kant, "Toward Perpetual Peace," 336.

${ }^{66}$ Ibid.
} 
"lawless" condition as that of individuals in the state of nature. For, as to states, Kant claims, "they already have a rightful constitution internally and hence have outgrown the constraint of others to bring them under a more extended law-governed constitution in accordance with their concepts of right". ${ }^{67}$

The superiority of public right over an arbitrary way of accommodating controversies between private individuals produces a shift away from any easy analogy of the international order with the domestic state of nature. For Kant, as for Rousseau, justice is realized through citizens' participation in collective political practices of deliberation, through the exercise of popular sovereignty supplemented by civic education. Ius cosmopoliticum represents a necessary "supplement to the unwritten code of the right of a state and the right of nations", it shows the possibility of a normative articulation of global principles of justice. ${ }^{6}$ It constitutes the condition of development of the ius gentium but it neither leads to an exercise of power with juridical rule - which is always statual or inter-statual - nor does it require a substitution or vertical dispersion of sovereignty. ${ }^{69}$

While replacing the individualistic aspect of cosmopolitanism with a project of global justice which aims to take into account the claims of all affected parties, the moral concern of cosmopolitanism is transformed into a typical Rousseauean political demand, vindicating the need for a collective effort at the level of the general will. However, Kant's ius cosmopoliticum does not abolish the preceding ius gentium; instead, it constitutes its historical-universal condition of development. This seems to be a relevant element to take into account while discussing the link between principles and agency in a theory of global justice. Within the Kantian paradigm, ius cosmopoliticum acts as a regulative principle orienting historical and political initiatives with global inspiration. Realizing such a principle requires however mobilizing political agency within the state

\footnotetext{
${ }^{67}$ Kant, "Toward Perpetual Peace," 327. Katrin Flikschuh rightly emphasizes the limits of the analogy between individuals and states with regard to the question of sovereignty. As she notices the relational metaphysics of Kant's Doctrine of right allows for a distinction between the former and the latter, the ability of individuals to claim rights does not precede but rather follow the existence of a sovereign authority. Unlike states, individuals are not right-enforcers; they may be compelled to enter a civil condition but an attempt to coerce states would result in the dissolution of every relation of right. See Flikschuh, "Justice or Virtue? Kant's Problem of "International Right"," 11 and 24-5.

${ }^{68}$ Kant, "Toward Perpetual Peace," 330-1.

${ }^{69}$ Contrary to what is usually assumed by contemporary cosmopolitans, for example Charles Beitz, "Cosmopolitan Liberalism and the States System," in Political Structuring in Europe, ed. Chris Brown (London: Routledge, 1994), 124-26, O'Neill, Bounds of Justice 171-85, Thomas Pogge, World Poverty and Human Rights (Cambridge: Polity Press, 2002) 182-95. I will return to contemporary perspectives in the next chapter.
} 
because only here the political, social and cultural conditions of reciprocity, required for the allocation of political obligations, may be found.

\section{$\underline{\text { 6. Statist cosmopolitanism? }}$}

Kant's statist cosmopolitanism may appear naif, relying as it does on political communities to provide the most appropriate associative framework for cosmopolitan political agency. One may object that states always seek to promote their own interests and that there is no reason why they should take seriously cosmopolitan political responsibilities, especially if such responsibilities challenge them to relinquish the benefits they presently receive. Kant acknowledges the strength of the objection. "Admittedly", he argues, "if there were no freedom and no moral law based upon it and everything that happens or can happen is instead the mere mechanism of nature, then politics, as the art of making use of this mechanism for governing human beings) would be the whole of practical wisdom" ${ }^{70}$ Interactions between states would rely on selfish interest, and the whole concept of cosmopolitan justice, indeed of justice altogether, would be "an empty thought". ${ }^{71}$

Yet morality does seem to have a role to play within domestic politics, it grounds the general will, and raises the concept of right to "a limiting condition of politics". 72 Since moral considerations are never ruled out domestically, it becomes plausible to assign the role of promoting global justice to "moral politicians", understood as agents who take seriously the principles of prudence but are also able to reconcile them with the requirements of morality. Similar agents, Kant claims, will act within the state in a way that promotes cosmopolitan justice. They will act based on the principle that "once defects that could not have been prevented are found within the constitution of a state, or in the relations of states, it is a duty [...] to be concerned about how they can be improved as soon as possible". ${ }^{73}$ For even though it would be absurd, and indeed contrary to both prudence and morality, to require that "those defects be altered at once and violently", it seems possible (and plausible) to ask moral politicians to "take to heart the maxim that such an alteration is necessary". ${ }^{74}$

\footnotetext{
${ }^{70}$ Kant, "Toward Perpetual Peace," 340.

${ }^{71}$ Ibid.

${ }^{72}$ Ibid.

${ }^{73}$ Ibid.

${ }^{74}$ Ibid.
} 
The last chapter of this work will return to the idea of similar agents (the cosmopolitan avant-garde) who make it their duty to act within the state in conformity with cosmopolitan initiatives. Here it seems important to stress that if enough citizens (Kant would say "moral politicians") were able to mobilize in favour of global justice, there would be nothing to prevent a transformation of states in a cosmopolitan direction. If anything, the associative conditions upon which the general will is founded within the state would provide a firm ground for further expanding its scope in a way that includes the claims of all affected parties.

It seems difficult to circumscribe Kant's contribution to a normative theory of global justice to the explicit formulation of "cosmopolitan" principles, as many authors seem to suggest. ${ }^{75}$ Taken literally, Kant's idea of cosmopolitanism is a rather limited one, restricted to conditions of "universal hospitality" and explicitly ruling out anything that goes beyond that. The real Kantian contribution to the global justice debate is unfortunately the one that has been most neglected. Kant was the only philosopher of the Enlightenment able to go beyond both the moral optimism of his cosmopolitan predecessors and the political pessimism of their anti-cosmopolitan adversaries. He could combine a cosmopolitan view of principles with a statist conception of agency. He did so not merely out of scepticism on the possibility of finding a global political authority able to enforce cosmopolitan justice but on grounds of a deeper critique to the limits of any political theory that detaches moral norms from the associative context in which they become political obligations.

Cosmopolitanism in Kant is not only a product of his theory of right and of the project of perpetual peace but, most importantly, a "regulative idea of history", guiding the progressive introduction of global moral principles in the development of collective democratic practices. The normative recognition of the validity of cosmopolitanism does not suffice to bridge the gap between valid moral imperatives and concrete political initiatives. Only the internal, conflicting development of each political process may lead

\footnotetext{
75 See Seyla Benhabib, Citizens, Residents and Aliens: Aliens, Residents, and Citizens (Cambridge: Cambridge University Press, 2004), Norberto Bobbio, L'età Dei Diritti (Torino: Einaudi, 1990), James Bohmann and Matthias Lutz-Bachmann, eds., Perpetual Peace: Essays on Kant's Cosmopolitan Ideal (Cambridge MA: MIT Press, 1997), Jurgen Habermas, The Inclusion of the Other: Studies in Political Theory (Cambridge Mass.: MIT Press, 1998), Jürgen Habermas, The Postnational Constellation (Cambridge: Polity Press, 2001), Pauline Kleingeld, "Approaching Perpetual Peace: Kant's Defence of a League of States and His Ideal of a World Federation.," European Journal of Philosophy 12 (2004), Kleingeld, "Kant's Cosmopolitan Law: World Citizenship for a Global Order.", Martha C. Nussbaum, "Kant and Stoic Cosmopolitanism," The Journal of Political Philosophy 5, no. 1 (1997). For a more balanced approach see Katrin Flikschuh, Kant and Modern Political Philosophy (Cambridge: Cambridge University Press, 2000).
} 
to a gradual transformation of selfish interests and prudential considerations into common moral ends.

The difficulties of realizing cosmopolitanism cannot be avoided by recurring to an ethics of the categorical imperative in politics. A complete theory of global justice must take into account the relationship between ideal and non-ideal, principles and agency, political theory and political practice: the latte promoting moral ends appropriate to each political stage and the former conferring clarity to these ends by expounding their ethical implications. This chapter has tried to illustrate from a historical perspective how states neither set an arbitrary limit to the principles of global justice (as many contemporary non-cosmopolitans insist) nor may be easily replaced by alternative agents (as their cosmopolitan rivals wishfully think). The task of unfolding such an argument in more analytical detail belongs to the remaining chapters. 


\section{PART TWO}

\section{DEFENDING THE STATE, DEFENDING COSMOPOLITANISM}




\section{Chapter II}

\section{Against the State?}

\section{$\underline{1 .}$ Preliminary remarks}

The present chapter focuses on contemporary cosmopolitan critiques of the state and on their defence of global egalitarianism. ${ }^{1}$ It exposes their flaws in arguing for global egalitarian principles and it ascribes such flaws to the cosmopolitan disregard of the normative relevance of particular political communities. It also introduces an alternative (Kantian-inspired) view of the role of political communities, which, far from weakening the case in favour of global egalitarian justice, lends support to it. ${ }^{2}$

The chapter targets in particular cosmopolitan arguments based on the claim that political communities are arbitrary for the scope of global justice. The argument from arbitrariness is usually invoked both with regard to the justification of principles of global justice (i.e. what kind of shares are global parties rightly entitled to) and with regard to the issue of agency (i.e. what motivates them to support institutions realizing cosmopolitan principles). This chapter tries to illustrate where cosmopolitans go wrong with regard to both issues and to explain why. It also emphasizes that it is unnecessary to criticize the state in order to prove the validity of cosmopolitan distributive principles or to solve the problem of agency in the global sphere. A strong case in favour of global equality could be made even if one conceded the normative relevance of political membership.

Let me start with a few methodological preliminaries. The focus of this chapter is rather narrow. Its critique targets only egalitarian forms of cosmopolitanism, i.e.

\footnotetext{
${ }^{1}$ The terms "global egalitarianism", "global distributive justice" and "global principles of distributive "equality" are here considered synonymous.

${ }^{2}$ Such an alternative is developed in further detail in the third part of this work.
} 
accounts trying to obtain global principles of distributive equality by applying a revised contractarian method of justification to the global sphere. ${ }^{3}$ Such accounts usually represent a "strong" form of cosmopolitanism, advocating demanding principles of global distributive equality rather than the mere satisfaction of basic needs or the recognition of general moral obligations to everyone. ${ }^{4}$

This chapter does not extend its critique to strategies defending weaker forms of cosmopolitanism such as duty-based, right-based, or consequentialist, to mention but the most prominent theories. ${ }^{5}$ Such weaker perspectives provide a less demanding but

\footnotetext{
${ }^{3}$ The defences of global distributive justice upon which I focus in the following pages are typically considered extensions of Rawls's domestic theory of justice to the global sphere. See Arash Abizadeh, "Cooperation, Pervasive Impact, and Coercion: On the Scope (Not Site) of Distributive Justice," Philosophy \& Public Affairs 35, no. 4 (2007), Brian Barry, "International Society from a Cosmopolitan Perspective," in International Society: Diverse Ethical Perspectives, ed. David Mapel; Terry Nardin (1998), Brian Barry, The Liberal Theory of Justice (Oxford: Clarendon Press, 1973) 128-32, Charles Beitz, "Cosmopolitan Ideals and National Sentiments," Journal of philosophy 80, no. 10 (1983): 591600, Charles Beitz, Political Theory and International Relations (Princeton Princeton University Press, 1999) 127-83 and 98-216, Darrel Moellendorf, Cosmopolitan Justice (Boulder, Colo.: Westview Press, 2002) 6-67, Thomas Pogge, Realizing Rawls (Ithaca Cornell University Press, 1989) 211-80, Thomas W. Pogge, "An Egalitarian Law of Peoples," Philosophy and Public Affairs 23, no. 3 (1994), David A. J. Richards, "International Distributive Justice," in Ethics, Economics, and the Law, Nomos Xxiv, ed. J. Roland Pennock and John W. Chapman (New York:: New York University Press, 1982), 275-79. Despite his emphasis on some limits of the argument, Simon Caney is also broadly sympathetic to this approach. See Simon Caney, "International Distributive Justice," Political Studies 49 (2001), Simon Caney, Justice Beyond Borders - a Global Political Theory (Oxford: Oxford University Press, 2005) 107-15, Simon Caney, "Justice, Borders and the Cosmopolitan Ideal: A Reply to Two Critics," Journal of Global Ethics 3 (2007). Some of the claims to which I refer in the following pages, in particular those regarding the distribution of natural resources, are also endorsed by Brian Barry, "Humanity and Justice in Global Perspective," in Contemporary Political Theory. An Anthology, ed. Robert E. Goodin and Philip Pettit (Oxford: Blackwell, 1982), Tim Hayward, "Global Justice and the Distribution of Natural Resources," Political Studies 54, no. 2 (2006). For one cosmopolitan-egalitarian perspective which does not share the premise of the arbitrariness of political membership see Tan, Justice without Borders : Cosmopolitanism, Nationalism, and Patriotism.

4 For the difference between "strong" and "weak" cosmopolitanism see Beitz, Political Theory and International Relations 198-99, David Miller, “The Limits of Cosmopolitan Justice," in In International Society: Diverse Ethical Perspectives, ed. David Mapel; Terry Nardin (Princeton: Princeton University Press, 1998), 166. Along similar lines goes the distinction drawn by Simon Caney between "mild" and "radical" cosmopolitanism and that discussed by Samuel Scheffler between "moderate" and "extreme" cosmopolitanism. See Caney, "International Distributive Justice," 974-77. and Scheffler Samuel Scheffler, Boundaries and Allegiances: Problems of Justice and Responsibility in Liberal Thought (Oxford: Oxford University Press, 2003) 114-16.

${ }^{5}$ For a duty-based approach, see Onora O'Neill, “Agents of Justice," Metaphilosophy 32, no. 1/2 (2001), Onora O'Neill, "The Dark Side of Human Rights," International Affairs 81, no. 427-39 (2005), Onora O'Neill, Bounds of Justice (Cambridge: Cambridge University Press, 2000).. Some prominent consequentialist strategies may be found in Garret Cullity, "International Aid and the Scope of Kindness," Ethics 105, no. 1 (1994), Garrett Cullity, The Moral Demands of Affluence (Oxford: Oxford University Press, 2004), Robert E. Goodin, Protecting the Vulnerable: A Reanalysis of Our Social Responsibilities (Chicago, IL: University of Chicago Press, 1985), Robert E. Goodin, "What Is So Special About Our Fellow Country-Men?," Ethics 98, no. 4 (1988), Martha Nussbaum, Frontiers of Justice (Cambridge (MA): Harvard University Press, 2006), Amartya Sen, Inequality Reexamined (Oxford: Oxford University Press, 1995), Amartya Sen, "Justice Across Borders," in Global Justice and
} 
often also rougher account of the exact distributive form cosmopolitan claims take when applied to existing political institutions. ${ }^{6}$ One objection they have attracted is that it is difficult to see who would not ascribe to the idea that there are duties owed to all human beings, regardless of their race, gender or citizenship, and that such duties may comprise the satisfaction of minimal subsistence claims worldwide. As one prominent critic of cosmopolitanism has put it, "my own position is also cosmopolitan by this criterion, since I have explicitly defended a universal obligation of justice to respect the basic rights of people everywhere". 7 This clarifies why my critique will be limited to strong cosmopolitan accounts: if we can reconcile statism and cosmopolitanism even when more demanding obligations of distributive justice are at stake, extending the argument to weaker forms of cosmopolitanism should be straightforward.

Further, it is also important to emphasize that in defending the role of political communities against global egalitarians using the contractarian device, this chapter does not attempt to restate familiar communitarian or particularist objections to contractarianism as such. It also does not emphasize the non-arbitrary standing of political communities in order to undermine the validity of cosmopolitan principles of distributive justice. Its main claim is more restricted and more constructive. The chapter does not deny the general possibility of using the social contract device to justify global distributive principles; it only argues against present cosmopolitan defences of global egalitarianism that consider political communities arbitrary for that purpose. ${ }^{8}$ It tries to

Transnational Politics, ed. Pablo De Greiff and Ciaran Cronin (Cambridge (MA): Mit Press, 2002), Peter Singer, "Famine, Affluence and Morality," Philosophy \& Public Affairs 1, no. 3 (1972), Peter Singer, One World: The Ethics of Globalization (New Haven Yale University Press, 2002). For a rights-based perspective, see Charles Beitz, "Human Rights as Common Concern," American Political Science Review 95 (2001), Charles Jones, Global Justice : Defending Cosmopolitanism (Oxford: Oxford University Press, 2001), Henry Shue, Basic Rights: Subsistence, Affluence, and U.S. Foreign Policy (Princeton: Princeton University Press, 1996). One of Thomas Pogge's seminal works on global justice, World Poverty and Human Rights, defends global justice from both a contractarian and a rights-based perspective. Pogge's apparently shifting position is due to the attempt to develop what he calls an "ecumenical" case in favour of global justice, which appeals to defenders of different strategies of justification. See the clarification in Thomas Pogge, "Real World Justice," The Journal of Ethics 9 (2005): 36-37. In this chapter I am only concerned with Pogge's arguments for distributive equality.

${ }^{6}$ See for the critique Charles Beitz, "Cosmopolitanism and Global Justice," The Journal of Ethics, no. 9 (2005): 17-18, Tan, Justice without Borders : Cosmopolitanism, Nationalism, and Patriotism 41-55. Some of these strategies may nevertheless be fruitfully employed to advocate more demanding global egalitarian principles. I return to this issue in chapter IV.

7 See David Miller, “Caney's 'International Distributive Justice': A Response," Political Studies 50 (2002): 975.

${ }^{8}$ This is also the main difference between my defence of political membership and that of Rawls in The Law of Peoples. Indeed the original position advocated by Rawls in this latter work starts with 
show that the cosmopolitan normative critique of political communities is both flawed and unnecessary. While failing to establish global distributive principles, a contractarian-styled cosmopolitan critique of political membership simply weakens the method's potential of justification.

In order to illustrate these points I examine a number of contractarian assumptions regarding both the choice situation and the background conditions required to develop principles of distributive justice. More particularly, I focus on some features of the original position concerning: i) the circumstances of justice; ii) the nature of the parties; iii) the use and function of the veil of ignorance. In the following three sections, I endorse the cosmopolitan version of the original position and try to illustrate some of its flaws in arguing for global distributive justice. Exposing some internal inconsistencies of this particular way of applying the contractarian model will serve to refute the argument that political communities are arbitrary for the scope of justice and to illustrate some weaknesses in existent defences of global egalitarianism.

\section{The circumstances of justice}

The fiction of a social contract represents in contemporary political theory a methodological device for investigating on the principles according to which the benefits and burdens of social cooperation ought to be distributed. Most famously associated to Rawls's A Theory of Justice, the contractarian method has recently been deployed by various cosmopolitan scholars trying to extend the findings of Rawls's domestic theory of justice to global political institutions. ${ }^{9}$ The idea of an original

representatives of states (or peoples) but rejects the possibility of justifying global distributive principles, see John Rawls, The Law of Peoples (Cambridge Mass: Harvard University Press, 1999) 118-21. I take Rawls to be right in stressing the relevance of political membership in the global application of the contractarian method but wrong in using this argument to deny the plausibility of global distributive principles. Since I only focus on cosmopolitan applications of contractarianism, I cannot go into the details of Rawls's global theory of justice in this chapter. Instead, I shall discuss some key features of his domestic theory of justice as endorsed by various cosmopolitan egalitarians and emphasize some of the flaws deriving from this endorsement when combined to the cosmopolitan claim for the arbitrariness of political communities. A more detailed discussion of Rawls's global theory of justice and of several arguments in its favour is provided in the next chapter.

${ }^{9}$ Because of its influence on egalitarian defences of cosmopolitanism, this chapter focuses only on the adaptation of Rawls's domestic contractarianism to the circumstances of international society. It does not either consider other versions of it such as David Gauthier's account or attempt to redress Rawls's premises where they do not seem quite compatible with classical contractarian theories such as Rousseau's or Kant's ones. What it tries to do is pointing at the tensions that the attempt to apply 
position in which reasonable contractors discuss a number of competing conceptions of justice and determine by overlapping consent principles for distributing benefits and burdens is extended to global political institutions. ${ }^{10}$

One of the fundamental premises of contractarian theories is to treat the principles of justice as necessitated by a specific choice situation. This situation is characterized by circumstances of justice, understood as background conditions that give rise to the necessity of coordinating the claims of conflicting parties with regard to the distribution of certain primary goods. The domestic theory of justice that contractarian cosmopolitans take as a starting point clarifies these conditions by endorsing specific circumstances of justice whereby certain subjective and objective factors make human cooperation both possible and necessary. ${ }^{11}$ On the one hand, sharing the same geographical territory, scarcity of resources, and human vulnerability to attack, are objective circumstances. The presence of scarcity means that resources are not so abundant to make human cooperation superfluous, yet scarcity is moderate in that it does not destroy all possibilities for a common venture. On the other hand, subjective circumstances refer to the motivational background of parties considered roughly equal in mental and physical powers: there is a complementarity of needs and interests, which makes possible assessing a cooperative venture, and there is a diversity of life plans which gives rise to conflicting claims on the best scheme of distribution. Furthermore, the parties consider their conceptions of the good as worthy of recognition but suffer from several limits, moral and natural, to the full exercise of their human capacities such as knowledge, thought and judgement. ${ }^{12}$

It is important to examine the global circumstances of justice upon which the cosmopolitan original position relies and to assess the role that the abstraction from particular political communities plays at this point of the argument. Let us consider first

Rawls's domestic theory of justice at the international level generates when combined with existing cosmopolitan arguments for the arbitrariness of political communities.

${ }^{10}$ Beitz, Political Theory and International Relations 129, Caney, Justice Beyond Borders - a Global Political Theory 107, Moellendorf, Cosmopolitan Justice 7, Pogge, Realizing Rawls 254, Richards, "International Distributive Justice," 272-82.

11 Rawls's domestic argument features in Charles Beitz, "Justice and International Relations," Philosophy and Public Affairs 4, no. 4 (1975): 366-67, Beitz, Political Theory and International Relations 130-31, Pogge, Realizing Rawls 242-54. The relevance of being in circumstances where resources are scarce and individuals have an interest in jointly framing principles of justice is emphasized also by Moellendorf, Cosmopolitan Justice 20-23.

12 Beitz, Political Theory and International Relations 130-31, John Rawls, A Theory of Justice, Rev. ed. (Cambridge, Mass.: Belknap Press of Harvard University Press, 1999) 110. 
the objective circumstances and start with the requirement that parties interact in a defined geographical territory under conditions of vulnerability and moderate scarcity. Several cosmopolitan scholars have suggested that we understand as territory the whole world and emphasize that the global original position should abstract from political membership. ${ }^{13}$ In similar circumstances of justice, cooperation under conditions of scarcity would be affected by two main factors. Firstly, there are the human and social efforts contributing to economic development and influencing the parties' different endowments of primary goods. Secondly, there is the natural component of human cooperation, those material resources or "utilities derived from any portion of the earth" due to would-be arbitrary features such as the parties' geographical location. ${ }^{14}$

It is precisely on this second element that the cosmopolitan original position relies in order to justify the need for a global principle distributing natural resources. Cosmopolitans argue that since political communities simply happen to find themselves in resource poor or resource rich regions of the earth, political membership is irrelevant for determining what individuals are entitled to in global circumstances of justice. Charles Beitz has considered this claim analogous to Rawls's account of natural talents in the domestic version of the contract and claimed that "citizens of a nation which finds itself on top of a gold mine do not gain a right to the wealth that might be derived from it". ${ }^{15}$ Resources must be present in nature before they are appropriated and "no

\footnotetext{
13 See, for example, Barry, The Liberal Theory of Justice 128-32, Beitz, Political Theory and International Relations 129-36,43-53, Moellendorf, Cosmopolitan Justice 30-40, Pogge, Realizing Rawls $247 \mathrm{ff}$. For a similar critique to Rawls's limitation of the original position to domestic societies see also Thomas M. Scanlon, "Rawls' Theory of Justice," in Reading Rawls. Critical Studies on Rawls' a Theory of Justice, ed. Norman Daniels (New York: Basic Books, 1975), 202-03.

${ }^{14}$ The expression is taken by Sidgwick and appears in Beitz's characterization of the circumstances of justice, see Beitz, Political Theory and International Relations 136-43.See also Beitz, "Justice and International Relations," 366-67.It must be noticed that Beitz presents two versions of the contractarian argument and that in one of them, while discussing the issue of natural resources, he concedes that the addressees of distributive claims may be representatives of states. This however complicates rather than making more straightforward his position. Indeed, the answer to the general question we are interested in - whether political communities are arbitrary for determining individual entitlements to natural resources and Beitz's claim that they are - remains unchanged in both versions. On the difficulty for states to accept a resource distribution principle on the basis of this latter assumption, see Hayward, "Global Justice and the Distribution of Natural Resources," 352-53., otherwise sympathetic to some of Beitz's claims and the critical remarks in David Miller, "Justice and Global Inequality," in Inequality, Globalization, and World Politics, ed. Andrew Hurrel; Ngaire Woods (Oxford: Oxford University Press, 1999), 191-98.

${ }^{15}$.Beitz, "Justice and International Relations," 368-69, Beitz, Political Theory and International Relations 141.
} 
one has a natural prima facie claim to the resources that happen to be under his feet". ${ }^{16}$ Thomas Pogge also emphasizes how "the natural assets in a state's territory are not a reflection of the moral worth of - are not deserved by - either this state or its citizens". ${ }^{17}$ Brian Barry goes on to make a similar claim when he argues that "the economic prospects of a country depend on something for which its inhabitants (present and past) can take absolutely no credit and lay no just claim to its exclusive benefits, namely its natural resources - including in this land, water, minerals and so on". ${ }^{18}$ Since the citizens of particular states have done nothing to deserve the natural resources lying under their soil, the parties in global circumstances of justice are entitled to an equal portion of the earth's natural resources, regardless of their political membership.

This argument is problematic. ${ }^{19}$ In the following pages I try to show how it is both problematic to assume that political communities are arbitrary for the distribution of natural resources and unnecessary to a contractarian-type of argument in favour of cosmopolitan justice. From the point of view of the former, I shall try to clarify what it means for resources to be available in nature and what role political communities might play in the claims of individuals to an equal share of the earth's resources. From the point of view of the latter, I shall argue that focusing on the arbitrariness of political communities for the distribution of natural resources unnecessarily weakens the use of contractarian strategies to justify cosmopolitan distributive principles.

\section{1. Where the arbitrariness-argument goes wrong}

Let us start with the first objection. Let us suppose that particular citizens of particular countries have done nothing to deserve the wealth potentially derived from the gold

\footnotetext{
16 Ibid.

${ }^{17}$ See Pogge, Realizing Rawls 250-51. A similar desert-based argument has led Pogge to justify a global resource dividend, see Pogge, "An Egalitarian Law of Peoples."

${ }^{18}$ Barry, "Humanity and Justice in Global Perspective." 534-5.

${ }^{19}$ Charles Beitz has articulated the argument at greater length. However, my remarks apply not only to Beitz but also to the other authors mentioned above, as well as to those scholars who have endorsed Beitz's claims on natural resources without questioning their coherence and indeed necessity from a contractarian perspective. See, for example, Hayward, "Global Justice and the Distribution of Natural Resources." and Caney, Justice Beyond Borders - a Global Political Theory 107-15. Although Caney does recognize some limitations of the cosmopolitan contractarian argument in delivering a complete theory of global distributive justice, he fails to see the role played by the critique of political membership in determining those limitations and is otherwise sympathetic to Beitz's argument.
} 
mine lying under their feet. Now the example of the gold mine which Beitz provides to illustrate what one finds in nature is already problematic since it is obvious that mines are not usually 'found' but constructed, in which case it may not be entirely arbitrary that those who constructed the mine are also entitled to its product. However I will not comment more on this point but simply assume that the word 'mine' has been wrongly used where one intended to refer to gold 'reserves'. The difficulty even with this latter assumption is that it is not the arbitrary fact of being out there, ready for use, which makes gold reserves amenable to the production of wealth. Gold reserves would not produce any wealth unless those potentially profiting from this wealth knew that it would be possible for it to do so. Whether given resources are needed and for what purpose does not depend on their availability in nature but on the social meaning they acquire and the use that is made of them. Therefore, while it may be true that the simple location of natural resources is arbitrary from a moral point of view, this arbitrariness is also irrelevant. What matters here is not determining whether individuals are justly entitled to an equal share of resources that could produce wealth but whether they are justly entitled to those that do. And in order to answer this latter question one has to establish whether the significance for use and potential value of such resources are everywhere the same regardless of community membership.

In order to understand that they are not, and that community membership constitutionally affects the social meaning of natural objects, consider the following anecdote that Marx tells when explaining the fetish character of commodities:

No divinity was so deadly to the savages as gold, which they believed certainly to be the Fetish of the Spaniards, judging the type of the Spaniards belief according to their own and according to the profound veneration they saw in the Spaniards for this metal. The barbarians of Cuba, knowing that a flotilla from Castille was going to descend on their land, judged that they had better conciliate first to the God of the Spaniards, and then distance it from themselves. They gathered all their gold in a basket. Behold they said the God of these foreigners; let us celebrate a festival in its honour in order to obtain its protection; in this way we will make it depart from our island. They danced and sang according to the way of their religion around the basket, then threw it in the sea. ${ }^{20}$

\footnotetext{
${ }^{20}$ The note appears in an unpublished manuscript of the International Institut für Sozialgeschiche in Amsterdam. Marx seems to have taken the anecdote from the book Du culte des dieux fétiches ou Parallèle de l'ancienne religion de l'Egypte avec la religion actuelle de Nigritie (1760) by the French writer Charles de Brosses. My quote is taken from Kevin Mac Laughlin, Writing in Parts: Imitation and Exchange in Nineteenth-Century Literature (Stanford: Stanford University Press, 1995) 13-14.
} 
The Cubans are thus unaware of the value of gold; they have simply observed that the Spanish adore it and have assumed that it must therefore constitute their god. It is not a natural resource they lack - the Cubans dispose of plenty of gold but they ignore the use that could be made of it. If their understanding and that of the Spanish naturally converged, they would have perhaps hidden the gold, exchanged it for other benefits, or traded it to their own advantage. Instead, interpreting the behaviour of the Spanish according to their specific cultural categories they think it more appropriate to dance and sing around gold, throw it into the sea and hope that this will suffice to expel the Spanish.

It seems clear here that the kind of society to which the Cubans and the Spanish belong is relevant to account for the way in which gold is valued and for the use that is consequently made of it. The difficulty with accepting the cosmopolitan claim on the arbitrariness of political communities resides in its assumption that the value given and, consequently, the use made of primary resources does not depend on their social meaning and on collective efforts to render them valuable. This argument, as one can see, wrongly focuses on individual entitlements in natural circumstances but underestimates the role of collective social and political factors.

Here two possible objections might arise. The first one is to say that even though one might agree that community membership plays a relevant role in shaping the social meaning of natural objects it is not clear why the boundaries of such significance-conferring community ought to be specifically domestic-political. The example above, one might argue, obscures the fact that the interest of Spain for gold was common to all European states at the time, thus inviting us to consider that the boundaries of the significance-conferring community might be wider than those of particular states.

Before we attempt to clarify how specifically domestic political factors might have an important role to play in the valorisation of natural resources, let me emphasize that such an objection does not contribute to strengthening the individualist cosmopolitan case in favour of the arbitrariness of political communities. It does not, in other words, show that it is possible to determine what natural resources individuals are entitled to if we completely abstract from community membership. Indeed the objection 
above grants that community membership matters but asks us to show why it is that domestic political boundaries are more relevant than additional social or cultural ones. Notice however that in so doing such an objection implicitly undermines the cosmopolitan case for an individualist distribution of natural resources with which we started. The objection, that is, does not prove the correctness of the cosmopolitan arbitrariness argument; it does not show that it is possible to determine what individuals are entitled to if they are considered as such. It simply tries to extend the relevance of political communities to take into account additional collective features and requires clarifying the specific role of state institutions in determining different ways of relating to natural resources.

Focusing precisely on the case of Spain in the sixteenth century, I try to show below that even in the presence of a general awareness on the relevance of natural resources (such as that shared by European elites at that time) domestic institutions mattered tremendously for understanding the performance of, say, Spain, France and Holland. Nevertheless, before going into the details of such claim let me emphasize what an objector would have to show in order to both prove the arbitrariness of political communities and strengthen the case for an individualist approach to natural resource distribution. In order to succeed with both tasks, a critic would need to argue for a global overlap in individual judgments with regard to what natural resources ought to be considered valuable. This is precisely what the second objection mentioned above attempts to show.

The second objection grants that social meaning might have mattered in the past in relation to conventionally precious metals. Yet it emphasizes that this does not seem to be the case under current circumstances of injustice, whereby all actors involved seem to know enough about what count as relevant scarce resources. Gold may not have been valuable for Cubans a few centuries ago, just as oil may not have been considered relevant by the citizens of Kuwait when it was first discovered. But when everyone is exposed to the pressure of the same international markets, as in current global economic practices, it seems hard to concede that people will fail to converge on their judgment of what natural resources are deemed to produce wealth.

Notice, however, that this objection only targets the idea that it seems difficult in a globalized world to abstract from community membership as far as epistemic 
considerations on what natural resources are likely to produce wealth are concerned. It does nothing to discredit the thought that those who have tried to transform potential wealth into actual wealth are entitled to the benefits of their work or bear responsibility for its loss. Products are not "found" in the state of nature and individuals do not enrich themselves by bumping into inherently valuable natural resources. Instead, even natural resources must be analysed, extracted, exchanged, traded and so forth. Human labour, scientific and technologic expertise, background infrastructures, societal, cultural and political circumstances are essential elements for the optimization of their exploitation. But how do we move from here to the fact that specifically political boundaries and domestic political factors have a relevant role to play in this process?

Going back to the previous example, precisely the case of Spain and its incredible rise and fall between the sixteenth and seventeenth century might help us illuminate the issue at stake here. Early sixteenth-century Spain was one of the largest political hegemons in Europe, influenced by Erasmian thought and in close contact with the rest of the continent's cultural centres. Ambitious monarchs such as Ferdinand and Isabella of Castile approved the Navigation Acts, invested resources in maritime enterprises following royal standards and together with Charles V seem to have played a major role in determining the success of colonial enterprises, morality of such enterprises aside. All the treasure entering in Europe during the sixteenth century passed through the ports of the country, no other state had access to American mines and the Spanish were the first to perfect amalgamation processes for extracting precious metals such as silver and gold. ${ }^{21}$

Within one century only however - roughly after 1598 - large parts of the population were on the verge of famine, maritime investments had practically ceased and following several naval defeats the Spanish flag allegedly disappeared from the seas. $^{22}$ Historians seem to converge on ascribing the causes of such failure to the Spanish culture of "hidalguia", the dissolute habits of the aristocracy, their avid expenditures on castles and jewellery instead of technological advancement, and the absence of an administrative reform for tax collection. In addition to these factors the persecution of Jews and Moors led to the migration of some of the most industrious and

${ }^{21}$ Earl J. Hamilton, "Imports of American Gold and Silver into Spain , 1503-1660," The Quarterly Journal of Economics 43, no. 3 (1929): 437.

${ }^{22}$ Earl J. Hamilton, “The Decline of Spain,” The Economic History Review 8, no. 2 (1938): 170. 
entrepreneurial workforce in the country whereas the prevalence of catholic bigotry and the consolidation of the Inquisition prevented students from attending foreign universities, impeding any intellectual exchange and rendering scientific and technological innovation improbable. ${ }^{23}$

It is not necessary to focus on further historical details here or to dwell on the morality of the colonial enterprise as a whole. Suppose colonized states did not suffer from violent resource-deprivation but rather agreed to concede the use of their territory for some other benefit, say because the Spanish promised to build schools in return. The point is that the mere availability of resources in nature seems irrelevant for determining how much Spain was able to profit from such availability as opposed to other European countries. Failure to adapt Spanish techniques to the French and Dutch standards of shipbuilding, to update technological expertise and to advance scientific enquiry seem to have been among the primary causes of the decline in standards of extraction and trade determining the eclipse in the country's shipping industry. The exclusive access of gold reserves throughout the century was unable to prevent the economic misery caused by a sinister development in the Spanish political system and by the obtuse choices of narrow-minded leaders. Out of fear from contagion by heretic thought, Spain was unable to compete with its neighbours and keep the pace with the political and cultural reforms that were taking place around Europe thus losing the advantage it initially had on the distribution of natural resources. The causes for the rise and fall of Spain in the sixteenth and early seventeenth century and its inability to compete with the rest of European nation states seem ascribable to domestic factors which differ from country to country: factors including the state's class structure, its particular legal system, specific minority policies, its dominant religious tradition and so forth. ${ }^{24}$

Membership in a particular political community need not entitle citizens to the primary resources that just happen to be territorially available. Yet the same does not

\footnotetext{
${ }^{23}$ John H. Elliott, “The Decline of Spain,” Past and Present 20 (1961): 52-75.

${ }^{24}$ For a different critique to the natural resources argument which also points at the relevance of political membership see David Miller, National Responsibility and Global Justice (Oxford: Oxford University Press, 2007) 58-62. Miller's claims do not prove the impossibility of justifying a global equal opportunity principle but only a specific way of applying the principle which seeks to equalize the position of individuals worldwide. In chapter IV I introduce a different approach to the question, showing how a global opportunity principle might be justified even if one takes into account Miller's critique.
} 
hold for the product of their use once they become accessible through collective human labour. Notice, however, that it is this and only this latter feature that seems relevant for distinguishing from all resources present in nature that could potentially produce wealth those few that are able to do so as a matter of fact. To say it more clearly, the claim that "the citizens of a nation which finds itself on top of a gold mine do not gain a right to the wealth that might be derived from it" is true so long as we are clear that "might be" is very different from "is". But what "might be derived" from natural resources is also irrelevant. Indeed as soon as that abstract possibility becomes a matter of fact those contributing to the actual conversion of natural resources into wealth may, by virtue of their efforts, have a justified claim to that wealth just as they may, by virtue of their misdeeds, be considered responsible for its loss.

Notice that I have explicitly left aside here the empirical discussion on whether access to natural resources is indeed the most important variable determining economic growth, all things considered. This question is controversial and requires much more empirical work to be settled. ${ }^{25}$ Instead, I have tried to show that even if we grant that natural endowments play a primary role in influencing material development, it would be impossible to abstract completely from community membership in determining how various agents value accessibility to natural resources, what use they make of it and consequently who is entitled to what.

That membership in a particular community is indeed essential to determine how one uses particular resources does not mean however that any cosmopolitan attempt to search for global distributive principles is inevitably bound to fail. It only shows that if cosmopolitans choose to pursue contractarian strategies in justifying global distributive principles, such strategy should avoid desert-based claims on political membership.

Now of course one might object here that even if it is impossible to abstract completely from the input of human labour and collective political responsibility in determining who is entitled to what, we might still consider an injustice the result of a specific allocation of natural resources in the presence of equal amounts of effort. Suppose, for example, that both Spain and the Netherlands had a very similar political

${ }^{25}$ See the discussions in Dani Rodrik, ed., In Search of Prosperity: Analytical Narratives on Economic Growth (Princeton: Princeton University Press, 2003). 
system, very similar social conventions and the same population size. If the Netherlands fared worse because of lack of access to natural resources, we might still consider it an injustice that Dutch citizens have to work harder to compensate for not having been blessed by nature in the distribution of natural resources. This objection does not however challenge the relevance of political communities in determining entitlements to the product of collective efforts; it merely shows that political membership is an irrelevant factor in the distribution of initial endowments. Something may be irrelevant without being morally objectionable. But if the defence of political communities is irrelevant (not wrong) for that initial process of endowmentdistribution, so is the cosmopolitan critique that usually accompanies it.

\subsection{Where the arbitrariness-argument becomes unnecessary}

This leads us to the second, even more serious, objection to the cosmopolitancontractarian critique of political communities. As I will attempt to show, not only is such critique misleading but also unnecessary to the cosmopolitan case for global distributive justice. To understand this point it is important to consider how the argument on the arbitrariness of political communities implicitly modifies the assumptions made in contractarian circumstances of justice. Recall that according to the contractarian premises with which we started, all that is required for given circumstances to qualify as objective circumstances of justice is for them to be characterized by a conflict over scarce resources and by a common interest in solving it. The contractarian perspective on the circumstances of justice is agnostic about the roots of this conflict, and does attempt neither to ascribe causal responsibility to any of the parties involved, nor to examine who was or could have been justly entitled to what prior to the conflict in question. The contractarian account is silent on how the parties found themselves in those specific circumstances of justice, and desert-based considerations are alien to the deduction of specific principles of justice.

This point is particularly clear in Rawls's domestic theory of justice which, as it has been pointed out, inspires several cosmopolitan-egalitarian reconstructions of the 
original position. ${ }^{26}$ Indeed, as Rawls puts it, "the principles of justice that regulate the basic structure and specify the duties and obligations of individuals do not mention moral desert, and there is no tendency for distributive shares to correspond to it". ${ }^{27}$ What matters is neither how the conflict came about, nor who is entitled to what, but in what way it continues to affect the parties' life in common and what kind of consequences it has for our fundamental social institutions.

This means that the principles that will eventually guide the re-allocation of scarce resources are not historical or rectificatory principles, trying to identify at which point in time a presumed just process of appropriation was interrupted. They are instead "end-result principles" according to which the justice of a distribution is determined by "how things are distributed (who will get what) as judged by some structural principle(s) of just distribution". ${ }^{28}$ In the contractarian account, the principles determining the pattern according to which resources should be distributed are the pure procedural ones resulting from an agreement among parties in the original position.

How does the cosmopolitan argument on the arbitrariness of political communities implicitly modify the contractarian account on the circumstances of justice? It does so by introducing an entitlement-based conception of justice that shifts focus from the social consequences of a specific distributive process to its initial starting point. ${ }^{29}$ By asserting that membership in a political community is arbitrary as regards what natural resources its citizens deserve to access in the first place,

\footnotetext{
${ }^{26}$ The focus on Rawls's claims here is important since the authors we are considering have no wish to depart from Rawls's contractarian assumptions in A Theory of Justice while reconstructing a cosmopolitan original position,. Charles Beitz for example emphasizes that "if one is inclined to reject Rawls's theory in the domestic case, then the case for a theory of global justice like the one suggested below is correspondingly weakened", see Beitz, Political Theory and International Relations 129. Thomas Pogge argues that his defence of contractarianism "is meant to show that Rawls offers a sound basis for progress in political philosophy as well as for political progress, see Pogge, Realizing Rawls 1. Simon Caney also believes that "Rawls's domestic theory of distributive justice [...] impels us to apply this theory globally", see Caney, Justice Beyond Borders - a Global Political Theory 116.

27 Rawls, A Theory of Justice 275. It is all too unfortunate that Rawls himself appears to have abandoned this important claim in his further discussion of global distribution in The Law of Peoples, where he introduces desert-based claims in assessing the causes of national economic development.

${ }^{28}$ For the distinction between historical and patterned principles of distribution see Robert Nozick, Anarchy, State, and Utopia (Oxford: Blackwell, 1974) 153-54.

${ }^{29}$ Cosmopolitans make precisely this move when they focus on the "entitlements" of individuals and enquire on the causes of the wealth of particular societies. As Simon Caney, recalling Brian Barry, argues: "there is no ground for saying that the member of the prosperous society can claim to be entitled to more" - see Caney, Justice Beyond Borders - a Global Political Theory 112. As I try to show below this statement is fallacious. There may be such grounds but if one consistently embraced the kind of contractarianism that cosmopolitans initially claim to embrace, they would not bear the weight that an entitlement-based perspective assigns them.
} 
cosmopolitans substitute the need for patterned principles of just distribution with a query on historical principles of justice in acquisition. ${ }^{30}$ This however implicitly assumes that the solution to the conflict over resources in given circumstances of justice may be obtained by proceeding backwards and identifying the unjust causes of an initial process of resource allocation. The kind of principles to which such an analysis leads are contained in the Lockean proviso, requiring the parties involved in the original process of acquisition to leave "enough and as good for others". Many cosmopolitans seem to sympathize with this type of analysis and the principles to which it leads. ${ }^{31}$ What they fail to realize is that there may be a tension between such principles and the contractarian premises employed at the start. Let us see why.

Suppose we wanted to show the arbitrariness of political communities in determining entitlements to the wealth produced by natural resources. We would first need to distinguish between human input and raw natural resources and while granting that political communities play a role in the former, we would claim to abstract from them with regard to the latter. We would then presumably identify some kind of rectificatory principles distributing equally natural resources in accordance with the Lockean proviso. It is not clear however, in what way this would contribute to resolving the conflict in existent circumstances of justice with which the contractarian account starts. Even more obscure is how it could justify the selection of "distributive" principles requiring a continuous re-allocation of primary goods, in an egalitarian form. A historical analysis of the circumstances of justice would lead, at best, to rectifying past injustice in acquisition. Following an entitlement-based conception, once the process of rectification is over one is free to ignore the further consequences of specific interactions, however great the inequalities produced by them. ${ }^{32}$ The logic underpinning an attempt to identify the historical patterns of resource acquisition is such that only the original processes of acquisition and transfer matter, not their outcome. This rules out

\footnotetext{
${ }^{30}$ Beitz acknowledges this point when he claims, in response to critics, that his ideas "would lend support to an argument for some global redistribution to compensate for the uneven distribution of natural resources or to rectify past injustices", see Beitz, Political Theory and International Relations 169. He fails to realize however that the kind of principles one obtains starting from these premises are very different from the ones he initially tries to justify on contractarian grounds.

${ }^{31}$ See, for example, Ibid. 139, Hayward, "Global Justice and the Distribution of Natural Resources," 360-61.Thomas Pogge explicitly uses the Lockean argument in justifying a global resource dividend, see his Pogge, "An Egalitarian Law of Peoples," 200-01.

${ }^{32}$ See the justification of this point in Nozick, Anarchy, State, and Utopia 162-63.
} 
the possibility of identifying end-state principles of distributive justice of the kind made necessary every time - for whatever reason - the parties find themselves in specific circumstances of justice.

One could of course argue here that cosmopolitan contractarianism may reconstruct the circumstances of justice in a way that ascribes conflict to an initial injustice in the process of acquisition. Once that conflict is over, cosmopolitan contractarianism might be satisfied with whatever inequalities arise because of successive interactions and ignore the need for further distributions of primary goods. Yet this statement would be incompatible with the cosmopolitan commitment to equality as an important human good, with the idea that everyone is entitled to equally adequate standards of well-being that constitutes the moral core of the theory. Equality in an entitlement-based conception of justice constitutes merely a starting point, not a criterion to satisfy any time a distributive conflict threatens stability in society and material inequalities arise. However, it is precisely the presence of this conflict, whatever its origin, and the amount of inequality to which it leads that seems to preoccupy contemporary cosmopolitan theories.

In short, arguing that political membership is arbitrary for determining the entitlements of individuals to a portion of the earth's natural resources is beside the point as regards resolving the conflicting claims of parties in contractarian circumstances of justice. Showing that the citizens of particular political communities do not deserve the wealth that they dispose is difficult, but it is also irrelevant. For even if those individuals or communities did deserve that wealth (as they indeed may) we would, true to our contractarian premises, assess the circumstances of justice from the point of view of their consequences on fundamental global interactions, not from the point of view of how it came about. And here the argument on the arbitrariness of political communities would become superfluous. Indeed even accepting that political communities are not arbitrary to determine the entitlements of their citizens, one could argue that there are relevant international circumstances of justice such that their consequences worldwide override desert-based claims of both communities and individuals and require us to rethink the principles promoting equality worldwide.

Consider the case of migration or the pressure put by economic globalization. These are only two among the most relevant examples of globally pervasive conflicts: 
they affect any political community in the world and everyone has a reason to accept principles that would allow resolving the tensions they bring about. It is not clear however how desert-based considerations on the arbitrariness of political communities help us identify the principles required. Surely, even if the companies of specific states had a legitimate claim to their wealth we would think it appropriate to tax them for the sake of improving the economic conditions of those negatively affected by their activity. Surely, even if some countries had deserved some additional wealth drawn from the use of natural resources we would think it appropriate to require they sacrifice part of such wealth to accommodate the claims of starving human beings. ${ }^{33}$ But the principles drawn out of desert-based considerations introduced by the argument on the arbitrariness of political communities give us no normative tools for dealing with issues such as these.

For standard contractarians, valid principles of justice in given conflicting circumstances - no matter how they arise - are those that no one could reasonably reject. Yet it is not clear how the argument on the arbitrariness of political communities contributes to their identification. Only the collective impact of the conflict in given circumstances of justice, and the reasons agents might have to solve it, need to be taken into account while reconstructing the contractarian perspective on global justice. ${ }^{34}$ Anything existent cosmopolitan accounts add to this point with regard to the arbitrariness of political membership loads the argument with unnecessary claims turning contractarianism into a weaker justificatory strategy.

\section{The nature of the parties}

Having illustrated some weaknesses in the cosmopolitan reconstruction of the contractarian account from the point of view of the circumstances of justice, I will now examine its critique of political communities by analysing the nature of the parties involved in the original deliberative situation. The previous section emphasized how the cosmopolitan account of the circumstances of justice modifies the contractarian

\footnotetext{
${ }^{33}$ I shall return to this issue in chapter IV.

${ }^{34}$ In chapter IV I show how one could justify global distributive principles starting from circumstances of justice that do not need to abstract from the parties' political membership.
} 
premises in a way that, even if justified, would lead to a different set of principles from the ones originally envisaged. This section tries to show how abstracting from political membership and relying on a cosmopolitan idealized account of the original position is unwarranted and renders those principles unnecessary.

Firstly, the section argues that the cosmopolitan reconstruction of the original position modifies and ultimately weakens the contractarian account of the subjective circumstances of justice. Secondly, it emphasizes that even if one accepts it hypothetically, the degree to which it moralizes the parties is so considerable that it becomes difficult to understand why principles of justice are needed in the first place. Finally, it suggests that a cosmopolitan-contractarian need not ground his case in favour of global distributive justice on dubious assumptions on the arbitrariness of particular political communities. One can instead start with an idea of agents embedded in particular social and political relations and consider political membership an important premise in the argument for global distributive equality.

\subsection{Where the arbitrariness-argument goes wrong}

Let us first clarify the nature of the subjects in cosmopolitan circumstances of justice. Without rejecting Rawls's domestic account on the circumstances of justice, Pogge starts with an idea of the global original position in which the "parties are representatives of persons, never of associations or states". ${ }^{35}$ Other cosmopolitans pursue this argument further. According to David Richards, since "one's membership in one nation as opposed to another and the natural inequality among nations may be as morally fortuitous as any other natural fact" all individuals are entitled to be included in the global original position as such. ${ }^{36}$ For Charles Beitz "if the original position is to represent individuals as equal moral persons for the purpose of choosing principles of institutional or background justice, then the criterion of membership is possession of the two essential powers of moral personality". 37

The cosmopolitan original position however, although claiming to start with a roughly analogous account to the domestic circumstances of justice, over-idealizes the

\footnotetext{
${ }^{35}$ Pogge, Realizing Rawls 247.

${ }^{36}$ See David A. J. Richards, A Theory of Reasons for Action (Oxford Clarendon Press, 1971) 290.

${ }^{37}$ Beitz, "Cosmopolitan Ideals and National Sentiments," 595.
} 
nature of the parties. One simply fails to understand why justice is at all required given everyone is so moral from the start. In standard contractarian theories, the issue appears more complex. Rawls's domestic theory of justice refers to Hume's account of society where parties are engaged in a conflict as well as an identity of interests. Cooperative interactions are due to the interdependence of needs and interests, rough equality of power and the limited natural and intellectual abilities of the parties. As Hume puts it: "By the conjunction of forces our power is augmented: By the partition of employments our ability encreases: By mutual succour we are less expos'd to the fortune of accidents". ${ }^{38}$ The need for principles of justice arises when equally powerful and equally motivated parties are willing to work together to resolve conflicting claims and to identify institutions that fairly distribute societal benefits and burdens. ${ }^{39}$

How does the cosmopolitan original position reframe the subjective circumstances of justice? What role does its critique of political communities play at this point of the argument? The first relevant difference concerns the presupposition of the rough equality of individuals in the global original position. While we can indeed assume that within particular political communities human beings are more or less equal in power due to their development in similar cultural circumstances and to their joint involvement in framing collective social institutions, it is obviously not so if we consider how very different social environments, standards of education and cultural backgrounds shape differential life expectations. The construction of a global original position cannot ignore how particular social, political and linguistic boundaries might exert a deep impact on the claims people make on each other and on the strategies chosen to pursue specific ends. Those differences in cultural, educational or religious backgrounds are so relevant that they might ultimately affect the very possibility of identifying a common set of primary goods subject to distributive requirements.

Consider the following example that a cosmopolitan egalitarian might suggest to show the relevance of global circumstances of justice where the parties coincide with

\footnotetext{
38 David Hume, A Treatise of Human Nature [1739], (Oxford: Oxford University Press 1985), 486. Rawls in A theory of justice underlines how his own account of the subjective circumstances of justice "adds nothing essential" to Hume's "much fuller discussion". As already emphasized, the contractarian cosmopolitans we are considering are also keen to emphasize that their account of the original position is simply an extension of Rawls's domestic contractarian account. For this reason I assume that the relevance of circumstances of justice in constructing a contractarian-type of argument in favour of global distributive justice remains the same.

${ }^{39}$ Rawls, A Theory of Justice 109.
} 
individuals and political membership is irrelevant. Suppose we start with a global original position where, for example, individuals from Papua New Guinea and individuals from Sweden are represented. It would be difficult to see how membership in each may be an arbitrary feature and how cultural, linguistic and educational backgrounds would not affect the bargaining capacity of such individuals. It is absurd to assume that the citizens of Papua have roughly equal needs and interests to the citizens of Sweden and from this conclude that they would also converge on the primary goods to be distributed worldwide. At least in the present stage of human development, the needs and interests contributing to make certain social goods desirable do not arise merely in response to natural motives but are mediated by cultural and historical factors, the organization of labour, standards of education, and so on. As the collective social and political environment that shapes the character of individuals as well as their social preferences, political communities cannot simply be ignored. Reducing membership to an "arbitrary" feature or pretending that one can abstract from it without affecting the way in which the parties will interact to choose specific distributive principles turns contractarianism into a much weaker justificatory device.

Of course, such cultural and educational differences between individuals matter even in domestic subjective circumstances of justice. However sharing a public political culture and being aware of the general facts of social cooperation that influence individuals' position within domestic institutional structures means that the chances of converging on a set of primary goods that individuals would require to be equally distributed are much greater in domestic circumstances. I will return to this point when discussing some aspects concerning the device of the "veil of ignorance" and its extension to issues of political membership. Here it is important to be clear that the argument I have put forward does not target any defence of the very idea of an original position but only those defences of it that believe it possible to ignore political membership.

But now consider the following objection. A critic might say that if the parties in the original position did not know which country they belonged, if they did not know whether the subjects in circumstances of justice were Papuans or Swedish, for example, they would converge on global principles of justice satisfying Papuans and Swedish 
people alike. Such principles would reform the world-political institutions in a way that provided individuals with equal opportunity sets worldwide thus designing a system of international cooperation that would benefit any of them, regardless of the country they ended up in. But if we accepted this suggestion we would encounter the well-known difficulty of identifying what exactly the principles of justice equalizing the position of individuals worldwide might consist of.

This problem goes under the name of the "metric problem". What it emphasizes is the difficulty in a culturally and politically plural world to identify a unique ranking of preferences and a metric of distribution that equally suits every individual in the same way. The issue at stake here is not merely due to an empirical difficulty of finding data that would allow us to compare the positions of individuals worldwide regardless of community membership. It is the difficulty of identifying the meaning of equality of opportunity in a culturally plural world, where social goods may be constructed and evaluated in entirely different ways. As one author points out, "we can only make judgments with any confidence in extreme cases, and in those cases, what seems at first sight to be a concern about inequality may well turn out on closer inspection to be a concern with absolute poverty or deprivation, a concern which suggests a quite different understanding of global justice". ${ }^{40}$ Thus, the difficulty of introducing an arbitrariness claim on political membership in contractarian defences of global justice is that it leads to an unwarranted defence of individual equality of opportunity. If we tried to rescue the argument by recurring to the facts of global poverty and severe deprivation, we might end up losing the specificity of global egalitarian claims.

\subsection{Where the arbitrariness-argument becomes unnecessary}

The cosmopolitan critique of political communities is not only problematic but also unnecessary for a contractarian case in favour of global justice. In order to understand

\footnotetext{
${ }^{40}$ This objection to the cosmopolitan argument on the arbitrariness of political communities has been made by David Miller, see Miller, National Responsibility, and Global Justice 68. Miller is however wrong to think that because it is difficult to identify a metric for equalizing opportunities between individuals this defeats any alternative cosmopolitan argument for global distributive principles. What he fails to realize is that the issue of who is affected by specific distributive principles may be separated from the issue of whether there are global distributive principles at all. Indeed it is possible to solve the metric problem by simply substituting equal opportunity for individuals with equal opportunities for states. I further explore this issue in chapter IV.
} 
this issue it is necessary to examine in further depth how the moral constraints cosmopolitans put on the parties in the global original position over-idealize global circumstances of justice. Consider first the contrast with domestic theories of justice. While embracing a Humean account on the subjective circumstances of justice, Rawls emphasizes two human features that create a special necessity for distributive principles: individual selfishness and moderate generosity. He then goes on to argue that this presumption ensures that the principles of justice do not rely on strong assumptions. Indeed "the original position is meant to incorporate widely shared and yet weak conditions". ${ }^{41}$ Justice constitutes the outcome of a shared agreement on common interests; it is the virtue of practices where "there are competing interests and where persons feel entitled to press their rights on each other". ${ }^{42}$ As Hume also reminds: "encrease to a sufficient degree the benevolence of men, or the bounty of nature, and you render justice useless, by supplying its place with much nobler virtues, and more valuable blessings". ${ }^{43}$ Were moral feelings reliable enough in every human being, justice would become superfluous.

The cosmopolitan original position inadvertently modifies this account of the nature of the parties. The model of international association envisaged in this case does not rely upon "free bargaining" but upon "some values that are genuinely shared". ${ }^{44}$ In the cosmopolitan account, the subjects of the original position represent "moral persons" who assess the rationality of global distributive principles "with reference to a baseline of equality". ${ }^{45}$ Clearly, the subjects involved in this choice situation are quite different from those interacting in Humean circumstances of justice. While in Hume's and, more ambiguously, Rawls' case the parties of the original position are strategic and selfish human beings interested in maximising their interests, in the cosmopolitan one they represent moral subjects, committed to some basic principles of equality and justice.

The difficulty with such an account is that by idealizing the subjects of the original position, cosmopolitanism relies precisely on that for which justice is required. Indeed, what differentiates the global original position from the domestic contractarian

\footnotetext{
${ }^{41}$ Rawls, A Theory of Justice 111.

${ }^{42}$ Ibid. 113.

43 Ibid. 494.

${ }^{44}$ Pogge, Realizing Rawls 227.

${ }^{45}$ Beitz, Political Theory and International Relations 203.
} 
one is that for the latter, the social contract does not constitute the outcome of moral agreement on a specific conception of justice but of the need to coordinate parties interested in framing common rules of interaction. Rawls's contractarianism here echoes Rousseau's enquiry on whether there can be "a legitimate and reliable rule of administration in the civil order taking men as they are and laws as they can be". As Rousseau puts it in the beginning of the Social contract, "I shall try always to reconcile in this research what right permits with what interest prescribes so that justice and utility are not at variance". 46

Far from starting with parties that naturally possess a sense of justice, this type of contractarianism justifies the necessity of external authority precisely in the case of the absence of agreement on general moral principles. Rather than creating ex nihilo a particular political union, one needs to presuppose it. Normative theory starts with a given set of political institutions and enquires on the principles needed for their reform. Rousseau also makes this point very clear while discussing the necessity of a legislator: "in order for an emerging people to appreciate the healthy maxims of politics [...] the effect would have to become the cause; the social spirit, which should be the result of the institution, would have to preside over the founding of the institution itself, and men would have to be prior to laws what they ought to become by means of laws". ${ }^{4}$

Hence, one cannot expect natural moral duties to ground political agreements, since it is precisely because of their unreliability that justice is required. As I tried to show in the first chapter, Kant also insists on the issue while discussing the role of political legislation in promoting human moral progress. Indeed, as he puts it, "it is not the case that a good state constitution is to be expected from inner morality; on the contrary the good moral education of a people is to be expected through a good state constitution". In fact, Kant adds, by relying on morality alone "nothing will be achieved". 48

This understanding of moral capacity not as an original property shared by all individuals but rather as a disposition of "humanity" which needs to be historically developed marks an important, though little noticed, difference with contemporary

\footnotetext{
${ }^{46}$ Rousseau, "Of the Social Contract," 40.

${ }^{47}$ Ibid., 80ff.

${ }^{48}$ Kant, "Toward Perpetual Peace," 336.
} 
cosmopolitan accounts. ${ }^{49}$ Far from raising obstacles to the emergence of moral personality, as in the cosmopolitan theories we are examining, membership in a political community contributes to its full emancipation. As Kant claims in his early essay on universal history, it is only by entering into a civil constitution that "all the germs implanted by nature can be developed fully". ${ }^{50}$ This also explains why, in Kant's theory of international relations, the conflict among different political communities is not quite analogous to the condition of individuals in an anarchical state of nature. Indeed states, unlike individuals, "already have a rightful constitution internally" and a republic is by nature "inclined to perpetual peace". 51 The public recognition of a collective authority limiting individual claims constitutes the first step towards a process of human emancipation by virtue of which political subjects agree to obey the laws that they have given to themselves.

If in this standard contractarian account of justice individuals in the state of nature are interest-maximisers and political communities provide the most relevant associative context in which their moral powers may be fully realized, the opposite occurs in the cosmopolitan account. The two relevant starting points for a cosmopolitan interpretation of the original position are the concept of individuals considered as "free and equal moral persons" and a bargaining situation from which all "morally arbitrary" factors should be excluded. ${ }^{52}$ As with Leibniz's cosmopolitan account, examined in the previous chapter, the parties are here individual moral units whose natural sense of justice leads them to favour specific global distributive principles. ${ }^{53}$ This issue is however controversial: if we could rely on such ideal premises, on individuals' altruism and ability to comply spontaneously with specific moral laws, one would have difficulty explaining how claims of justice might arise.

One response might be that justice is required for reasons of coordination, in order to support the parties' distribution of benefits and burdens and prevent unintended consequences of social interactions. But if this were indeed the case, what is gained by

\footnotetext{
${ }^{49}$ For an excellent analysis of the difference, emphasizing the relational metaphysical requirements of Kant's Doctrine of Right see Flikschuh, Kant and Modern Political Philosophy 185-89.

${ }^{50}$ Kant, "Idea for a Universal History with a Cosmopolitan Purpose," 52.

${ }^{51}$ Kant, "Toward Perpetual Peace," 104.

${ }^{52}$ Beitz, Political Theory and International Relations 203, Caney, Justice Beyond Borders - a Global Political Theory 115, Moellendorf, Cosmopolitan Justice 32-3 and 37-8.

${ }^{53}$ How the individual moral sense of justice arises is a separate issue that $\mathrm{I}$ assess in the following section.
} 
declaring political communities arbitrary from a moral perspective? If anything, they might contribute to a partial resolution of the coordination dispute by making available a set of institutional mechanisms through which the claims of members (at least) are accommodated. This thought, as already emphasized, animates Kant's statist cosmopolitan account of international justice where, far from being arbitrary entities, collective political agents who have internally realized public right subject themselves to external non-coercive agreements serving their interest in just reciprocal relations.

Cosmopolitans need not over-idealize individuals or prove political communities arbitrary in order to reflect on international circumstances of justice. Showing that a conflict between subjects roughly equal in abilities and needs gives rise to specific claims of justice is possible even starting from premises that recognize the relevance of political membership. Following Rousseau and Kant, one might argue that existing tensions among states and an unequal distribution of power in the global sphere threaten to deliver an unfair international system of cooperation and to disadvantage the life-prospects of citizens in each political community.

On this view, rather than assuming the widespread diffusion of naturally moral subjects, we would consider the state a cultivating ground for cosmopolitan morality. Taking part in collective processes of decision-making already limits the arbitrary wants of individuals, teaches them to live in common, and educates them to a sense of the collective. Once individuals have learned to live in a political association, it is easier for them to see the advantages of fair collective deliberation and consider the interactions between them and outsiders from a less narrow-minded perspective. International anarchy would be just as unattractive as the anarchy of the state of nature and having enjoyed the benefits of abandoning the latter they might be more motivated to also exit from the former.

The advantage of such a view is that it need not start from dubious assumptions about the degree of moral awareness individuals in circumstances of justice must already possess. It is sufficient to argue that some members of the international society have reasons to want to avoid the potential harms of a perpetual condition of international anarchy and may jointly contribute to the establishment of a collective and 
cooperative institutional regime. ${ }^{54}$ Of course, one might retort here that considering political membership in this light is as ideal as the assumption of moralized parties in the cosmopolitan contractarian account we are trying to challenge. Some implications of this objection are considered more in detail in the following section.

\section{$\underline{4 . T h e ~ s e n s e ~ o f ~ j u s t i c e ~}$}

To justify the assumption of moralized parties and the shift away from the postulates of mutual disinterest and limited altruism characterizing domestic circumstances of justice cosmopolitans might underline the hypothetical character of the social contract. Such an interpretation would be coherent with an interpretation of the original position as an "idea of reason" that allows us to think of the choice situation in ways "similar to the point of view from which noumenal selves see the world". 55 The idea is operationalized through the device of the veil of ignorance concealing all contingent information on particular characteristics of the parties and facilitating their consequent choice of the principles based on purely rational moral motives. This section examines the demands of the veil of ignorance in the global original position and illustrates some of its shortcomings in bracketing political membership and generating support from a cosmopolitan conception of agency.

In A Theory of Justice, Rawls clarifies that the idea of a veil of ignorance is introduced in order to eliminate the effects of specific contingencies that would tempt people to exploit the choice situation to their own advantage. Thus, "the veil of ignorance deprives the persons in the original position of the knowledge that would enable them to choose heteronymous principles". 56 The parties in the original position are unaware of their class and social status, or do not know their particular natural talents or social skills, and ignore their life-plans as well as their psychological disposition to specific opportunities. ${ }^{57}$ The informational restrictions introduced by the veil of ignorance aim to guarantee bargaining conditions which should lead to fair

\footnotetext{
${ }^{54}$ The English School analysis of international society relies precisely on these assumptions see, for one example, Hedley Bull, The Anarchical Society: A Study of Order in World Politics (London Macmillan, 1977). I will return to the issue of designing a fair system of international cooperation where inequalities of power are reduced in chapter IV.

${ }^{55}$ Rawls, A Theory of Justice 225.

${ }^{56}$ Ibid. 222.

${ }^{57}$ Ibid. 118.
} 
principles of justice endorsed by all contracting parties.

\subsection{Where the arbitrariness-argument goes wrong}

Cosmopolitans suggest that in the global original position, the veil of ignorance should extend to the parties' knowledge of the particular community to which they belong. Beitz has argued that "the parties to the original position cannot be assumed to know that they are members of a particular national society [...]. The veil of ignorance must extend to all matters of national citizenship, and the principles chosen will therefore

apply globally". ${ }^{58}$ Pogge has also emphasized how "nationality is just one further deep contingency (like genetic endowment, race, gender, and social class) one more potential basis for inequalities that are inescapable and present from birth". If one takes seriously the idea of abstracting from all contingent features for the sake of a fair bargaining situation, he claims, "there is no reason to treat this case differently from the others". 59

This argument has been criticized by underlining how such an extended interpretation of the veil of ignorance in the original position would make it difficult to assess which institutions fall under considerations of justice and which ones could be taken for granted. ${ }^{60}$ It is emphasized for example that, if followed rigorously, the cosmopolitan thought experiment might challenge every institution through which individuals organize collectively, not only political communities but also international organizations, civil associations, the market sphere, and even the family. An indiscriminate extension of the veil of ignorance in the global sphere appears to raise the question of the amount of information that the parties would choose to maintain or reject. If the idea of the veil of ignorance were pursued to its logical conclusion, the parties would not only ignore their citizenship but also the generation to which they belong, the economic and political conditions of the international sphere, humanity's level of civilization, and so on. Martha Nussbaum underlines this point by claiming that: "if you do not know that a multinational cooperation exists, you will probably not imagine one as part of an ideal structure of global justice. [I]f you do not know about the Internet, it will not be easy to imagine it; but then you will not be able to address the

\footnotetext{
${ }^{58}$ Beitz, Political Theory and International Relations 151.

${ }^{59}$ Pogge, Realizing Rawls 247.

${ }^{60}$ See, for example, Nussbaum, Frontiers of Justice 264-72.
} 
inequalities created by differential access to it" ${ }^{61}$

This critique however seems to neglect one important feature of the veil of ignorance and risks being misleading. While the thought experiment requires individuals to abstract from contingent personal features in the original choice situation, it does not exclude the knowledge of general facts about society as well as of the basic principles of political organization. One of the most relevant elements characterizing the parties behind the veil of ignorance is that they are taken to know as little as possible when it comes to specific individuals preferences, talents or social status and as much as possible on the general rules of the system of cooperation to which their conception of justice applies. As Rawls clarifies, "there are no limitations on general laws and theories, since conceptions of justice must be adjusted to general systems of social cooperation which they are to regulate, and there is no reason to rule out these facts". 62

The real question raised by the cosmopolitan extension of the veil of ignorance is then not so much absence of clarity about how far the thought experiment can proceed without becoming impracticable. It is, rather, whether the parties' political membership is the kind of knowledge one can afford to ignore without weakening the justification of global distributive principles. Here there are two possibilities to consider. In one version of the cosmopolitan argument, we might imagine individuals abstracting from the existence of any form of collective association and deliberating, in general, whether a global distribution of benefits and burdens should follow territorial lines with a designated authority holding monopoly over the use of force. The parties in the original position, that is, would ignore the existence of states and reflect on whether some kind of state-like form of organization would be appropriate in reforming the basic structure of society. ${ }^{63}$

This argument appears particularly weak however. Egalitarian conceptions of domestic justice applies to society understood as a well-established system of practice and is grounded on assumptions considered to be widely shared. From this perspective,

${ }^{61}$ Ibid. 266.

${ }^{62}$ Rawls, A Theory of Justice 119.

63 This would be the interpretation more in line with Beitz's statement that "it is not the case that we begin with an actually existing basic structure and ask whether it is reasonable for individuals to cooperate in it. Rather, we begin with the idea that some type of basic structure is both required and inevitable [...] and work towards principles the structure should satisfy". Beitz, Political Theory and International Relations 203. For an analogous statement see Pogge, Realizing Rawls 139-41. 
ruling out some kind of general knowledge about the existence of a world divided into bounded political communities seems inappropriate. Indeed, in the domestic case, the parties do not question the existence of certain institutional arrangements such as the constitution, courts of justice or the presence of market interactions. These are all taken for granted as part of society's basic structure. Rather the burden of decision relies on what kind of constitution, what kind of courts and what kind of markets, are required to accommodate the claims of justice. Analogously, in the international sphere the question is not whether political communities ought to exist at all but rather how the distribution of benefits and burdens among a given plurality of them could be conceived.

This leads us to a second potential restriction that the veil of ignorance might introduce regarding the parties' information on their political membership. One might imagine that although knowing about the existence of particular political communities and their characteristics, the subjects of a global original position are deprived of knowledge as to how they relate to each other. For example, each subject in the original position might be aware that China, Zimbabwe, and the United States are part of the world's political map, and they might also have access to the general social facts relevant to those countries, yet simply ignore whether (s)he is Chinese, Zimbabwean, or American. According to this second cosmopolitan interpretation, the only relevant feature to take into account while evaluating claims of justice in the global original position would be whether all parties have "a capacity for an effective sense of justice and a capacity to form, revise, and pursue a conception of the good". ${ }^{64}$

The appeal to the parties "effective sense of justice" is indeed crucial to build a persuasive contractarian case in favour of specific distributive principles. In Rawls's domestic theory the sense of justice motivates the parties to act by the principles chosen in the original position, thus illustrating how justice as fairness emerges as the most stable conception given a plurality of alternatives. As Rawls puts it: "a system in which each person has, and is known by everyone to have, a sense of justice is inherently stable. Other things being equal, the forces making for its stability increase as time

\footnotetext{
${ }^{64}$ See Barry, "International Society from a Cosmopolitan Perspective.", Beitz, "Cosmopolitan Ideals and National Sentiments," 595-96, Richards, A Theory of Reasons for Action 272-82 and 389-93.
} 
passes".65

This emphasis on "time" as a crucial feature for understanding how the sense of justice may develop and strengthen among the subjects of the original position is linked to the moral psychology that A Theory of Justice, inspired by Rousseau's Emile, provides. ${ }^{66}$ The appeal to the moral force of the "purely conscientious act", "the desire to do what is right and just simply because it is right and just" is clearly not enough. ${ }^{67}$ Rousseau was among the first to raise the question of moral motivation in the acceptance of contractarian principles when he claimed that: "it is not by sumptuary laws that luxury can be successfully extirpated; it is from the depth of the heart itself that you must uproot it by impressing men with healthier and nobler tastes". ${ }^{68}$ Here the willingness to act not merely due to coercion but spontaneously according to the principles of justice depends upon practices of cooperation in a particular society. It relates to specific processes of psychological and political emancipation, to the way in which individuals come to form their beliefs, rely upon specific intuitions and discard others, and develop feelings of mutual trust and solidarity. In order for justice as fairness to emerge as the most stable conception in a constructivist procedure of justification, the parties' sense of justice must reflect the public norms of political communication as rooted in the institutional development of a particular society. Indeed, "what justifies a conception of justice is not its being true to an order antecedent to and given to us, but its congruence with our deeper understanding of ourselves and our aspirations, and our realization that given our history and the

\footnotetext{
${ }^{65}$ John Rawls, "The Sense of Justice," The Philosophical Review 72, no. 3 (1963): 293. The question of stability is at the heart of the third part of A Theory of Justice and was considered by Rawls one of the main issues motivating the reassessment of this first major work in Political Liberalism. In the latter, the problem of moral motivation is linked very clearly to the public culture of a particular political association. "Given certain assumptions specifying a reasonable human psychology and the normal conditions of human life, those who grow up under just basic institutions acquire a sense of justice and a reasoned allegiance to those institutions sufficient to render them stable. Expressed another way, citizens' sense of justice, given their traits of character and interests as formed by living under a just basic structure, is strong enough to resist the normal tendencies to injustice. Citizens act willingly so as to give one another justice over time. Stability is secured by sufficient motivation of the appropriate kind acquired under just institution”. See John Rawls, Political Liberalism (New York: Columbia University Press,, 1993) 142. For a more critical appraisal of this question and of the transition from A Theory of Justice to Political liberalism see Brian Barry, "Rawls and the Search for Stability," Ethics 105, no. 4 (1995).

${ }^{66}$ Rawls, "The Sense of Justice," 281.

${ }^{67}$ Rawls, A Theory of Justice 454.

${ }^{68}$ Rousseau, "Considerations on the Government of Poland," 177-260.
} 
traditions embedded in our public life, it is the most reasonable doctrine for us". ${ }^{6}$

\subsection{Where the arbitrariness-argument becomes unnecessary}

It is now easy to see how the cosmopolitan construction of a global original position modifies classic contractarian assumptions on the parties' sense of justice so as to unnecessarily weaken the method's justificatory potential. The cosmopolitan extension of the veil of ignorance to issues of political membership requires precisely that the history, traditions and civic life shaping the social expectations and motivation of different subjects are considered arbitrary features and assumes that they play no role in the parties' forming an "effective sense of justice". While imprudently ignoring the criterion of stability in the justification of global distributive principles and ambiguously returning to an ideal doctrine of the "purely conscientious act", the cosmopolitan-contractarian reconstruction of the global original position encounters an even greater obstacle. It places behind the veil of ignorance features that might be crucial for understanding the basis for public agreement and conceals all the commonsense intuitions that one needs to take into account in weighting alternative views. Ultimately, it fails to examine the background assumptions that might lead to a widely acceptable account of distributive justice.

By bracketing the parties' attachment to a particular set of collective political institutions, the cosmopolitan reconstruction of the global original position is left with a rather obscure view on the parties "effective sense of justice" and an extremely weak analysis of what might motivate them to act in accordance with specific principles. Except for a few moral heroes, an "effective sense of justice" does not arise exclusively out of the subjects' attachment to pure moral motives but may be socially and politically constructed as well as specific to each form of collective political association. To claim that an innate, universal "sense of justice", understood as an unconditional compliance with rationally justified principles, might be very rare or that one needs to take into account the way particular societies inform their members' desire for justice does not mean ruling out that it might be possible to justify distributive

${ }^{69}$ John Rawls, "Kantian Constructivism in Moral Theory," The Journal of Philosophy 77, no. 9 (1980): 519. 
principles on a global scale. What it emphasizes is that extending the veil of ignorance on issues of political membership might not be the most appropriate kind of informational restriction to introduce in the global original position in order to ensure a fair justificatory procedure. The sort of knowledge that one would be brought to ignore in this case might affect what remains of the parties' sense of justice, thus turning the contractarian account into a very weak methodological device.

One might of course object here that the sense of justice amounts to nothing more than the motivation to comply that people internalize by virtue of living under just institutions. If this were indeed so, the veil of ignorance would not conceal any important information: one may emphasize that people behind the veil have a minimal motivation to comply so that whatever sense of justice we assume domestically we can count on internationally too. In a way, it is undeniable that, with regard to some issues at least, people's sense of justice overlaps worldwide, regardless of political membership. Perhaps one does not need to know where he or she comes from to consider torturing babies wrong and the sense of justice on this particular question would be enough strong to support institutions prohibiting such a practice. Whether this kind of thin, reactive, motivation is also enough to support the more demanding global distributive reforms required by cosmopolitan egalitarian justice is a different matter. Domestically at least, the sense of justice is not due merely to people's abstract respect for a public system of rules. It is complemented by other psychological pro-attitudes, developed in the process of growing in a particular political community, of sharing the values of a public culture, of maturing particular attachments to a set of people, of speaking the same language, and of knowing a particular history. But cosmopolitanegalitarians need not consider these features arbitrary or detrimental to their own cause: they may instead approach global political reform by virtue of an internal transformation of political communities compatibly with cosmopolitan goals. ${ }^{70}$ The veil of ignorance on issues of political membership does nothing to consolidate people's motivation to comply with cosmopolitan principles. It merely succeeds in weakening the sense of justice that they might already have thus rendering global political reform even more difficult to achieve.

\footnotetext{
${ }^{70} \mathrm{I}$ further explore such issues in chapters V and VI.
} 


\section{Conclusion}

Assessing existent defences of global distributive justice with a particular emphasis on the cosmopolitan critique of political membership, I have rejected the claim that political membership is arbitrary for the scope of justice. Focusing on the circumstances of justice, the nature of the parties, and the use and function of the veil of ignorance, I have argued that the cosmopolitan attempt to abstract from political membership in justifying global distributive principles is both unwarranted and unnecessary. With regard to the first issue - the circumstances of justice - the cosmopolitan analysis of the role of political communities unnecessarily introduces desert-based claims that, even if justified, would lead to historical principles of justice and not to the distributive ones originally required. With regard to the second issue (the nature of the parties), the cosmopolitan attempt to bracket political membership over-idealizes the contractarian premises and moralizes the subjects of the original position to the point of abolishing all instances of conflict and rendering justice unnecessary. In the third case, I tried to illustrate how the demand to extend the veil of ignorance to issues of political membership limits the parties' sense of justice, negatively affects the quest for stability and fails to indicate which widely shared intuitions might provide a common ground for public deliberation among parties at the global level. Rejecting the normative standing of political communities does not reinforce the case for global distributive principles; it succeeds only in turning contractarianism into a very weak justificatory strategy.

Existing defences of the normative relevance of the state usually couple with a critique of all cosmopolitan arguments in favour of global distributive justice. Here I tried to separate the two questions, and while forcefully rejecting several cosmopolitan arguments concerning the arbitrariness of political communities, I remained agnostic about the possibility of justifying global distributive principles once we admit the role of political communities. The main aim of this chapter has been critical and interpretative. If one takes seriously the need to integrate the moral core of cosmopolitanism with principles regulating the global distribution of benefits and burdens, efforts made to deny the relevance of political membership may be liable to undo the argument. 


\section{Chapter III}

\section{Against Cosmopolitanism?}

\section{Preliminary remarks}

We already emphasized how any reform of social institutions must start with people as they are and reflect on laws as they should be. Normative theory can (and ought to) apply the highest moral standards to its analysis of society - yet it will only deliver sound principles when placing its premises at the appropriate level of abstraction. ${ }^{1}$ The previous chapter tried to show how starting with all too ideal assumptions on the arbitrariness of political membership may end up undermining the very aims of cosmopolitan theories. This chapter targets non-cosmopolitan approaches and argues that their limitation of egalitarian obligations to state-based associative relations will leave us with an objectionable account of global justice. ${ }^{2}$

\footnotetext{
${ }^{1}$ On the role of abstraction in moral theories and the importance of working with non-idealizing yet abstract premises see Onora O'Neill, "Abstraction, Idealization and Ideology in Ethics," in Moral Philosophy and Contemporary Problems, ed. J.D.G. Evans (Cambridge: Cambridge University Press, 1987), Onora O'Neill, Towards Justice and Virtue: A Constructivist Account of Practical Reasoning (Cambridge: Cambridge University Press, 1996) 38-48. For critiques of O'Neill's attempt to distinguish between idealization and abstraction see Robert E. Goodin, "Political Ideals and Political Practice," British Journal of Political Science 25, no. 1 (1995), Lisa H. Schwartzman, “Abstraction, Idealization, and Oppression," Metaphilosophy 37, no. 5 (2006).

${ }^{2}$ Just like the cosmopolitan approaches considered in the previous chapter take inspiration from $A$ Theory of Justice, most of the non-cosmopolitan accounts I consider in the following pages have proliferated after the publication of Rawls, The Law of Peoples. However since there are important departures from Rawls's model and The Law of Peoples is substantially less developed than A Theory of Justice, this chapter will be less textual in its investigation than the previous one. I shall consider arguments offered by authors typically considered critical of cosmopolitanism, even when they do not endorse all of Rawls's premises. See for defences of Rawls's theory of global justice Samuel Freeman, "The Law of Peoples, Social Cooperation, Human Rights, and Distributive Justice" Social Philosophy and Policy 23, no. 01 (2006), Aaron James, "Constructing Justice for Existing Practice: Rawls and the Status Quo " Philosohy and Public Affairs 33, no. 3 (2005), Jon Mandle, Global Justice (Cambridge: Polity Press, 2006), Richard Miller, "Cosmopolitanism and Its Limits," Theoria (2004), David A. Reidy,
} 
Besides criticizing non-cosmopolitan accounts of global justice, this chapter also assesses the role that ideal and non-ideal considerations should play in normative theorizing about global justice more broadly. ${ }^{3}$ It argues that the failure of both cosmopolitans and non-cosmopolitans to combine adequately a reflection on matters of principle with a reflection on matters of agency is due to the inability of both to place ideal and non-ideal constraints at the right level within their theories. Clarifying how cosmopolitans and non-cosmopolitans confuse or misplace ideal and non-ideal considerations should pave the way to understanding the alternative approach to global justice developed in the rest of this work. Once we have explained at which stage of normative theorizing on global justice, cosmopolitan or non-cosmopolitan observations ought to prevail, it may be easier to reconcile the normative defences of both cosmopolitanism and the state.

The chapter proceeds as follows. I start by outlining the ideal vs. non-ideal distinction in political theory and recall how cosmopolitans have been ideal on issues in which non-ideal considerations should prevail whereas their critics are non-ideal where an ideal approach would be more appropriate. To clarify such issues further, I examine a number of arguments non-cosmopolitans have offered to reject global egalitarianism. More specifically, I consider the non-cosmopolitan foundation of distributive equality on state-based associative relations and the issue of what kind of alternative principles

\footnotetext{
"Rawls on International Justice, A. Defense," Political Theory 32, no. 3 (2004). For recent influential variations, see Michael Blake, "Distributive Justice, State Coercion, and Autonomy," Philosophy \& Public Affairs 30, no. 3 (2001), David Miller, "Collective Responsibility and International Equality in the Law of Peoples," in Rawls's Law of Peoples, ed. Rex Martin; David Reidy (Oxford: Blackwell, 2006), Miller, National Responsibility and Global Justice, Thomas Nagel, "The Problem of Global Justice," Philosophy \& Public Affairs 33, no. 2 (2005), Mathias Risse, "Do We Owe the Global Poor Assistance or Rectification?," Ethics \& International Affairs 19, no. 1 (2005), Mathias Risse, "What to Say About the State," Social Theory and Practice 32 (2006), Andrea Sangiovanni, "Global Justice, Reciprocity, and the State " Philosophy \& Public Affairs 35, no. 1 (2007).

${ }^{3}$ For an early paper on the transition from ideal theory to non-ideal considerations see Michael Phillips, "Reflections on the Transition from Ideal to Non-Ideal Theory," Noûs 19 (1985). For recent critiques to much "ideal" theorizing about justice more generally see Colin Farrelly, "Justice in Ideal Theory: A Refutation," Political Studies 55 (2007), Amartya Sen, "What Do We Want from a Theory of Justice?," The journal of philosophy 103, no. 5 (2006). For defences of the role of ideal theory see Gerald A. Cohen, "Facts and Principles," Philosophy \& Public Affairs 31, no. 3 (2003), Andrew Mason, "Just Constraints," British Journal of Political Science 34 (2004), Zofia Stemplowska, "What's Ideal About Ideal Theory?," Social Theory and Practice (2008), Adam Swift, "The Value of Philosophy in NonIdeal Circumstances," Social Theory and Practice (2008). For attempts to distinguish between effective and ineffective ideal theorising see Ingrid Robeyns, "Ideal Theory in Theory and Practice," Social Theory and Practice (2008), Laura Valentini, "On the Apparent Paradox of Ideal Theory," Journal of Political Philosophy (200?). and for a discussion of the role of ideal and non-ideal considerations in global justice debates see Pablo Gilabert, "Global Justice and Poverty Relief in Nonideal Circumstances," Social Theory and Practice (2008).
} 
of justice may substitute a cosmopolitan approach. On the first point, I argue that the non-cosmopolitan defence of the state is ideal when it ought to be non-ideal: it discusses the relevance of special relations from a justificatory perspective instead of considering which conception of human relations supports political transformation in the world as we know it. On the second point, I try to show that the discussion on remedial principles for fighting global poverty is non-ideal, limited to examining the impact of severe material deprivation in unfavourable conditions of domestic poverty. It ought to be ideal: investigating on the ideal principles of justice emerging from global circumstances of injustice.

While discussing both issues (the foundation of distributive equality on statebased associative relations and the priority given to principles of assistance to burdened societies) I also emphasize the failure of existent cosmopolitan counter-arguments to respond at the appropriate level of analysis. Instead of criticizing their rivals for confusing the roles of ideal and non-ideal assumptions, cosmopolitans have endorsed their methodological premises and entered potentially endless substantive controversies on the nature of associative duties and the corresponding principles of distributive justice. Clearing the ground from such methodological confusion on both sides will introduce to a (hopefully) more sophisticated way of combining ideal and non-ideal in discussions of global justice as well as anticipate some of the issues developed in our third part.

\section{Ideal and non-ideal: the two-stage construction}

We tend to think first and foremost of Rawls when differentiating between ideal and non-ideal. But of course the distinction goes back at least to Plato. It emerges most clearly in books five and six of The Republic where Socrates attempts to defend his ideal theory of the polity from one critique of Glaucon that he considers to be the "greatest and heaviest wave" faced so far by his account. Glaucon's initial argument is that every previous reflection Socrates has offered on perfect justice and the ideal polity relies on the assumption of full compliance and citizens' motivation to obey the polity's 
laws. ${ }^{4}$ Yet these considerations seem to deflect the discussion from the real issue Socrates needs yet to address: "is such an order of things possible, and how, if at all"? 5

Glaucon's remarks proceed from a contrast between the hypothetical acceptance of ideal principles of justice ("if only this state of yours were to come into existence we need say no more about them") and the practical feasibility of transforming a polity in a way that conforms to such principles ("assuming then the existence of the State, let us now turn to the question of possibility and ways and means - the rest may be left"). ${ }^{6}$ Yet, Socrates rejects such strong distinction between the normative and empirical level of analysis and attempts to illustrate their mutual implication. He does so firstly by clarifying the regulative role of an "ideal" of justice when reflecting on the highest virtues of the polity; and secondly by focusing more specifically on the agents and transformations that would bring about a social order if such ideals were realized in practice.

The first point concerns the nature of the relationship between the hypothetical possibility of the principles of justice and their exhibited reality. That relationship can be one of merely of approximation rather than one of perfect compatibility. Ideals embody the abstract representation of a polity run by perfectly just principles principles that everyone would have a reason to endorse if their judgments were impartial. $^{7}$ The assumption of perfect compliance is intrinsic to those being normative ideals rather than descriptive accounts. Firstly we need to assume that the polity's citizens will be equally motivated to promote ideal justice, only afterwards we can go on to consider what non-ideal institutional arrangements could offer the best scheme for its realization.

\footnotetext{
4 "I will add, what you have omitted, that your citizens will be the bravest of warriors, and will never leave their ranks, for they will all know one another, and each will call the other father, brother, son; and if you suppose the women to join their armies, whether in the same rank or in the rear, either as a terror to the enemy, or as auxiliaries in case of need, I know that they will then be absolutely invincible; and there are many domestic advantages which might also be mentioned and which I also fully acknowledge". See The Republic 471d, in Plato, The Collected Dialogues of Plato Including the Letters.. ${ }^{5}$ Ibid., 471e.

${ }^{6}$ Ibid.

${ }^{7}$ If we enquire into the "the nature of absolute justice and into the character of the perfectly just, and into injustice and the perfectly unjust", Socrates claims, then "we might have an ideal". At the hypothetical stage of the analysis ideals only perform a regulative function, "we were to look at these in order that we might judge of our own happiness and unhappiness according to the standard which they exhibited and the degree in which we resembled them”. See, The Republic, 472.
} 
The second point, regarding the feasibility of an "ideal" polity in non-ideal circumstances, concerns the issue of political organization in attempting to realize the ideal principles of justice. To say that ideal principles constitute a standard for evaluating the polity's degree of justice in non-ideal circumstances, and to require that the latter (circumstances) are progressively modified so that they reflect the former (principles), raises the question of "by whom" and "how" this change is going to take place. Approximation clearly does not imply that "the actual State will in every respect coincide with the ideal", i.e., the realization of the principles of justice does not assume perfect compliance. As Socrates says in reply to the request for a "feasibility proof" of how legislators and political mechanisms might progressively conform to the ideal: "if we are only able to discover how a city may be governed nearly as we proposed, you will admit that we have discovered the possibility which you demand; and will be contented". 8

The feasibility of politics paying this mediating role in shaping the social conditions under which the ideal principles of justice are progressively realized in practice need not depend on the perfect compliance of all citizens. In The Republic Socrates suggests that it suffices that a special class of subjects, those who appear less corruptible and more likely to pursue the idea of justice for its own sake, are assigned responsibility for being political guides and civic educators. Socrates was here referring to philosophers but we do not need to enquire further on either the significance of this proposal or its adaptation to modern conditions and the interesting substitution of the category with what Rousseau would have later called the "legislators" and Kant the "moral politicians". 9 We need merely note instead the two-stage construction of a coherent theory of justice: firstly, focus on the ideal principles according to which a polity's institutions ought to be shaped under conditions of perfect compliance; secondly, assign responsibility for the project's practical realization to the most adequate agents of change in non-ideal circumstances.

Several theories of justice, both domestic and international, adopt a formally analogous approach. The usual modus operandi most familiarly associated nowadays with Rawls is to divide the theory into two parts: the first, "ideal", part defines a

\footnotetext{
${ }^{8}$ Ibid. Emphasis added.

${ }^{9}$ We already noticed this issue in Chapter I. I will return to it in the final chapter.
} 
standard of social interaction worked out in favourable conditions of cooperation and perfect compliance. Once the principles according to which all affected parties decide to shape their common social institutions are established, the question of how to deal with cases of non-compliance, lack of motivation or historical failures to realize such an ideal is assigned to the non-ideal part of the theory of justice. ${ }^{10}$

Yet the combination of ideal principles with non-ideal presuppositions, existing background institutions and particular associative relations in global theories of justice is far from clear. Cosmopolitan accounts, as we pointed out in the previous chapter, are typically more or less always ideal. They over-moralize parties in the global original position or they fail to account for how ordinary agents might be motivated to promote cosmopolitan political initiatives. ${ }^{11}$ Even those authors underlining the need to take seriously non-ideal circumstances end up admitting that "even if it is unlikely that the ideal would be fully realized it is implausible to insist that no necessary steps towards that ideal should be taken". ${ }^{12}$ But this response is clearly insufficient. Positively identifying the agents and circumstances under which the benefits and burdens demanded by ideal principles of justice could be distributed is a necessary requirement for any politically sensitive global theory of justice.

On the other hand, non-cosmopolitans take seriously political circumstances and defend the relevance of existing associative relations in determining the scope of distributive equality. Their approach to global justice is, more or less, non-ideal: the point, they claim, is not so much to establish how the world should look like if its basic social institutions were redesigned from scratch but how we could justify their existence to people affected by them. Yet non-cosmopolitans are often criticized for simply endorsing the global status quo when they emphasize how equality requires

\footnotetext{
${ }^{10}$ John Rawls's A Theory of justice contains several clear statements of the ideal/non-ideal distinction, some of which are very much in line with the Platonic conception of ideas as regulative principles guiding the transformation of social reality. Consider the following "The intuitive idea is to split the theory of justice into two parts. The first, or ideal part assumes strict compliance and works out the principles that characterize a well-ordered society under favourable circumstances. (...) Nonideal theory, the second part, is worked out after an ideal conception of justice has been chosen; only then do the parties ask which principles to adopt under less happy conditions”. See Rawls 1999a, p. 216.

${ }^{11}$ For the motivational critique see Andrew Dobson, "Thick Cosmopolitanism," Political Studies 54, no. 1 (2006), Toni Erskine, "Embedded Cosmopolitanism and the Case of War: Restraint, Discrimination and Overlapping Communities," Global Society 14, no. 4 (2000), Lukas Meyer, "Liberal Cosmopolitanism and Moral Motivation," Global Society 14, no. 4 (2000), David Miller, On Nationality (Oxford: Oxford University Press, 1997) 53-65. I return to this critique in chapters V and VI.

${ }^{12}$ Simon Caney, "Cosmopolitan Justice and Institutional Design: An Egalitarian Liberal Conception of Global Justice," Social Theory and Practice 32, no. 4 (2006): 752.
} 
sovereignty as a "general enabling condition"13 or when they deploy unwarranted empirical arguments to avoid scrutinizing the global economic order from the point of view of ideal justice. ${ }^{14}$

Some problems with such an account and with the cosmopolitan response to it are examined more in detail in the following two sections.

\section{What's ideal about associative relations?}

The first point of controversy between cosmopolitan and non-cosmopolitan approaches to global justice concerns the grounds of distributive equality. Non-cosmopolitan accounts consider distributive obligations grounded on special associative relations. These associative relations are usually understood either in a cultural or in a political way. As far as cultural relations are concerned, it is often claimed that distributive justice requires a bounded political community where social goods are equally valued and in which citizens share "common sympathies" motivating them to comply with reciprocal distributive obligations. ${ }^{15}$ As far as political relations are concerned, it is emphasized that the cooperative or coercive nature of state institutions places on those institutions higher burdens of justification with regard to the relative well-being of the people they represent. ${ }^{16}$

Cosmopolitans emphasize that, on both points, non-cosmopolitan accounts rely on controversial empirical assumptions concerning the reasons for which distributive equality is a justified worry only within particular political communities. Against the first, cultural, argument the normative relevance of states is criticized for romanticizing the national community and for not taking into account that "common sympathies" may

\footnotetext{
${ }^{13}$ Nagel, "The Problem of Global Justice," 116.

${ }^{14}$ Indeed, Rawls and those who agree with his argument in The Law of Peoples, consider the issue of poverty in the world a typical instance of "non-ideal" theory, concerned with our duties of assistance to particular burdened societies. See Rawls, The Law of Peoples 23-25 and Miller, "Collective Responsibility and International Equality in the Law of Peoples."

15 See David Miller, “Against Global Egalitarianism," The Journal of Ethics 9 (2005): 55-79, Miller, National Responsibility and Global Justice 23-50, Miller, On Nationality 49-80, Michael Walzer, Spheres of Justice: A Defence of Pluralism and Equality (Oxford Robertson, 1983) ch. II.. The "common sympathies" premise is introduced by Rawls, see Rawls, The Law of Peoples 23-25. Rawls takes it from John Stuart Mill, Considerations on Representative Government, ed. Geraint Williams (London: Everyman, [1861] 1993) 391.

${ }^{16}$ For the political-associativist argument see especially Blake, "Distributive Justice, State Coercion, and Autonomy.", Nagel, "The Problem of Global Justice.", Risse, "What to Say About the State.", Sangiovanni, "Global Justice, Reciprocity, and the State”.
} 
be lacking in culturally heterogeneous societies or may not follow territorial lines but rather ideological or group-based ones. ${ }^{17}$ Against the second, political, argument it is often emphasized how instances of coercion and cooperation may be found even in international institutions affecting individuals' life globally. Hence, critics claim, there are no good reasons for grounding distributive equality on special relations within existing state boundaries. ${ }^{18}$

But of course non-cosmopolitan accounts following Rawls intend their theory of global justice to be ideal. The point - they argue in response to the first question - is not so much verifying whether any existing collection of individuals really exhibits all the relational properties associated with the normatively relevant features for grounding distributive obligations. No one, certainly not liberal theorists, would deny the existence of fundamental disagreement on comprehensive doctrines among citizens of modern societies or build consent on a substantive account of the common good. ${ }^{19}$ But an ideal theory of global justice does not need to imply that any existing society actually fulfils the criteria non-cosmopolitans ascribe to it. The relevant question is instead whether the notion of "common sympathies" constitutes a sufficiently desirable form of human social organization to serve as the basic unit of the global society, not whether it realistically describes any actually existing state. ${ }^{20}$ Hence, cosmopolitans use non-ideal arguments to discredit a theory that their rivals intended to be ideal, as if one wished to have apples and was told that oranges are bad for his health.

Suppose however, that non-cosmopolitans convinced cosmopolitans about the normative relevance of the ideal argument in favour of culturally homogenous entities. Cosmopolitans would still want to know why such entities should differ along

\footnotetext{
${ }^{17}$ See Charles Beitz, "Rawls's Law of Peoples," Ethics 110, no. 4 (2000). and Nussbaum, Frontiers of Justice 245.

${ }^{18}$ For such critiques see Abizadeh, "Cooperation, Pervasive Impact, and Coercion: On the Scope (Not Site) of Distributive Justice.", Joshua Cohen and Charles Sabel, "Extra Rempublicam Nulla Justitia?," Philosophy \& Public Affairs 34, no. 2 (2006), A. J. Julius, "Nagel's Atlas," Philosophy \& Public Affairs 34, no. 2 (2006), Ryan Pevnick, "Political Coercion and the Scope of Distributive Justice," Political Studies 56 (2008).

${ }^{19}$ In Political liberalism and in The Law of Peoples, Rawls is clearly aware of this point. Indeed he clarifies that if the sharing of "common sympathies" depended on language, history and political culture, "this feature would rarely, if ever, be fully satisfied". Nevertheless, "the Law of Peoples starts with the need for common sympathies, no matter what their source may be" for "if we begin in this simplified way, we can work out political principles that will, in due course enable us to deal with more difficult cases where all the citizens are not united by a common language and shared historical memories". See Rawls, The Law of Peoples 25.

${ }^{20}$ Ibid.
} 
territorial lines. If we are merely interested in ideal possibilities, cosmopolitans might plausibly insist, then gender, religion or social class - to give only few examples - are more relevant units of aggregation around common sympathies than the noncosmopolitan assumption of bounded political communities. ${ }^{21}$

The second line of defence of special associative relations tries to provide an answer to this objection. It does so by setting aside special cultural relations, and focusing instead on special institutional ones. Contra cosmopolitans, their critics emphasize justice's specifically "political" character. They argue that the priority of states (and not individuals or other groups) as grounds for distributive equality does not rely on individualist principles of justice or on a moral comprehensive doctrine. Instead, it relates to the presupposition of a particular kind of associative relation that justice requires in order to be exercised. Principles assessing the justice of particular institutions should reflect the nature of that institution and do not apply uniformly to all kinds of entities, including individual choices. ${ }^{22}$ In the non-cosmopolitan version of this last argument, principles of distributive justice presuppose the existence of a collective body that mutually acknowledges, cooperatively enacts and coercively imposes a particular institutional framework reflecting the political ideal of reciprocity and enjoying the legitimacy of its members. ${ }^{23}$

This argument is problematic. The fact that justice requires state-based political institutions to be exercised does not mean that its principles may only be considered valid within states' domestic jurisdiction. The non-cosmopolitan argument rests on a

\footnotetext{
${ }^{21}$ Allen Buchanan, "Rawls's Law of Peoples: Rules for a Vanished Westphalian World," Ethics 110, no. 4 (2000), Simon Caney, "Cosmopolitanism and the Law of Peoples," Journal of Political Philosophy 10 , no. 1 (2002), Andrew Kuper, "Rawlsian Global Justice: Beyond the Law of Peoples to a Cosmopolitan Law of Persons," Political Theory 28, no. 5 (2000).

${ }^{22}$ This idea comes from Rawls, see in particular Rawls, "Kantian Constructivism in Moral Theory." For a recent restatement see Andrea Sangiovanni, "Justice and the Priority of Politics to Morality," The Journal of Political Philosophy 16, no. 2 (2008).. For a defence of the opposite claim that the principles of justice should be fact independent see Cohen, "Facts and Principles."

23 A response similar to the one just sketched, seems to characterise several recent attempts to move beyond communitarian or Law of peoples-type of arguments. See for the coercion-based argument Blake, "Distributive Justice, State Coercion, and Autonomy." For the cooperation-based argument, see Freeman, "The Law of Peoples, Social Cooperation, Human Rights, and Distributive Justice ". and, more ambiguously, Nagel, "The Problem of Global Justice." For the reciprocity - based argument see Sangiovanni, "Global Justice, Reciprocity, and the State". The "feasibility" criterion is literally central to Rawls's justification of a peoples-based global original position. As he puts it there: "historically speaking, all principles and standards proposed for the law of peoples must, to be feasible, prove acceptable to the considered and reflective public opinion of people and their governments" Rawls, The Law of Peoples 49.
} 
confusion between legitimacy as a criterion of feasibility with agreement as a criterion of moral justification. It seems to rely on a shift away from the question of what kind of relations ground valid distributive claims and should be included in the normative assessment of the principles of justice (Socrates' ideal of the polity) to what kind of relations would need to be in place for such an ideal to become a feasible one (Glaucon's concern with non-ideal circumstances). From the point of view of the former justice is interested in the conditions of possibility of fair distribution, rectification or commutation among all affected parties (or all parties finding themselves in specific circumstances of justice). This is a matter of principle. ${ }^{24}$ From the point of view of the latter, justice shows the way in which particular institutions create special sets of obligations, the fulfilment of which is not a matter of individual good-will but rather of collective constraint among members of specific associative schemes. This is a matter of agency.

Issues of principle and issues of agency must not be confused, but they should also not be isolated from each other. We could conceive of them as part of the same theory, but simply characterizing each of its two stages. In the first stage, the ideal part of the theory, the principles regulating interactions among different subjects would only have to take into account their relations within specific circumstances of global (in)justice. In the second, non-ideal, stage, we would be concerned with the transformation of existing political institutions and the criteria constraining collective initiatives ought to be politically sensitive: feasibility, legitimacy, stability.

Notice that in tracing such a distinction between principles and agency we need not abstract from the political membership of subjects in specific circumstances of justice, as we have seen several cosmopolitans do in the previous chapter. We may even grant that there will be special sympathies or special political relations between some people and not others. Saying that such issues need to be taken into account already in the first stage is not the same as saying that when they are taken into account they necessarily undermine the global scope of distributive equality. What we need to emphasize is that where such associative relations obtain particular significance is the

\footnotetext{
24 "All affected parties" may not coincide with those parties that contingently find themselves in the same territory or share a set of common political institutions for it is possible to conceive of subjects of justice which suffer the consequences of decisions taken in political spheres that they are unable to control. For a deeper analysis of the challenges that this poses see Robert E. Goodin, "Enfranchising All Affected Interests, and Its Alternatives" Philosophy and Public Affairs 35, no. 1 (2007).
} 
second stage of the theory, when the issue of agency for the realization of cosmopolitan claims is discussed. Indeed all the arguments usually brought by non-cosmopolitans to defend the normative standing of states become relevant at this second (non-ideal) stage. For example, coercion is necessary to guarantee feasibility, reciprocity is necessary to guarantee legitimacy, cooperation is necessary to guarantee stability. But it would be as wrong to prioritize such criteria already at the level of principle in order to constrain the scope of equality, as to ignore them altogether.

Prioritizing special associative obligations at the level of principle runs the risk of arbitrarily excluding people who might be affected by the economic policies of powerful states in just the same way their citizens are. If associativist arguments obtained, non-citizens would cease to be a target of distributive claims - all other things being equal - simply because they lived on the other side of the border. We have ruled out in the previous chapter that political membership may be considered arbitrary. But this is not the same as saying that it should have distributive priority, or that it should have any kind of priority in the ideal stage of the theory. Accepting the noncosmopolitan prioritization of the state at an ideal level runs the risk of promoting an unduly exclusionary conception of distributive justice. Such an account fails to take into account how citizens and non-citizens alike might cooperate in producing specific goods and be equally affected by structural economic injustices. Why not start with a more inclusive conception of relevant relations among citizens of different states and consider whether particular distributive claims follow from there?

There may be an objection here. A cosmopolitan could argue that it is impossible to even get started with the analysis of global distributive principles if one does not abstract from political membership. Otherwise cosmopolitan principles might be rejected (even at the ideal level) from citizens of states who do not share values often associated with liberal cultures such as autonomy, impartiality or fairness. ${ }^{25}$ The argument however seems to rely on the assumption that only parties educated in liberal societies are able to engage in a certain kind of deliberation in specific circumstances of justice. But the history of thinking about justice is longer than the history of liberalism and, if anything, the latter represents only one possible model for solving distributive

25 This seems to be one of the main worries lying behind Rawls's constructivist approach to global justice, particularly his rejection of distributive principles, see Rawls, The Law of Peoples 66. 
conflicts in an institutional way (and not necessarily the most successful one). In the situation I have just sketched, we do not expect subjects in circumstances of justice to share the same political model of organization since this question is left to the initiative of non-ideal agents. Instead, we make the much less demanding argument that they will probably discuss, confront and share specific distributive concerns and even though these may arise from a plurality of ethical systems such systems do not need to be incommunicable. ${ }^{26}$

Having introduced a distinction between issues of principle and issues of agency (the first kind of query belonging to the ideal part of the theory and the second to its non-ideal part), it seems easier to see where recent approaches to global justice go wrong. Most cosmopolitan accounts focus on the ideal part of the theory, on the claims of principle, and seem to undermine the question of agency in transforming social and political institutions by ignoring questions of compliance and motivation. Issues of feasibility are, to be sure, occasionally raised. But even when they are, it is difficult to know precisely what kind of agents are supposed to take initiatives for reforming which particular institutions, where the locus of political decision-making is supposed to be in the global sphere and how decent arrangements reflecting the principles of justice are supposed to emerge given cosmopolitan's scepticism towards state-based agency. ${ }^{27}$ Taking seriously into account non-ideal agency, for example the coercive power of states, the associative conditions under which ideal principles of justice become feasible and agents might be motivated to promote cosmopolitan initiatives would immensely benefit the political allocation of distributive cosmopolitan obligations.

Non-cosmopolitan theories, on the other hand, do seem to pay attention to the relevance of states in the global sphere. But they confuse issues of agency with issues of principle: they limit egalitarian concerns to particular political boundaries yet lack a normative account of how one ought to deal with cases where the circumstances of

\footnotetext{
${ }^{26}$ For further analysis of this issue see Henry Shue, "Thickening Convergence: Human Rights and Cultural Diversity," in The Ethics of Assistance: Morality and the Distant Needy, ed. Deen K. Chatterjee (Cambridge: Cambridge University Press, 2004), 221-33.

${ }^{27}$ Onora O'Neill and Thomas Pogge for example, discuss the question of agency in the international order only to undermine the role of states and argue for the need to replace them with other international actors, i.e. NGOs, multinational corporations, regional or trans-national bodies which could perform analogous functions. See O'Neill, Bounds of Justice 181-85, Pogge, World Poverty and Human Rights 186-95. Their arguments do not however go beyond a statement of intentions. Indeed, it is difficult to see how, having acknowledged the role of states as the main actors of the international society as they do, one can proceed to reform the global order ignoring the role of states.
} 
justice do not necessarily coincide with specific state boundaries. This is particularly evident if we consider the case of global poverty, one other source of controversy between non-cosmopolitans and cosmopolitan approaches to global justice where the consequences of the ideal/non-ideal confusion emerge clearly again. The following section considers some shortcomings of non-cosmopolitan arguments with regard to the principles required to fight global poverty and introduces an alternative way of exploring the circumstances of global justice.

\section{What's non-ideal about global principles?}

In the previous section, I underlined the mistaken application of ideal and non-ideal categories in recent accounts of global justice with regard to the relations necessary to ground claims of distributive equality. More specifically, I emphasized that all arguments either for or against the centrality of states were played at the "ideal" level (discussing the role of state-based relations in grounding distributive equality) when they should have been "non-ideal" (raising the issue of feasibility and stability in the application of the principles of global justice). This suggests that, in order to complete the two-stage construction of a global theory of justice, rather than discussing the role of states' from an ideal perspective, one should focus on the political agency they make available in non-ideal circumstances. This means placing at the heart of normative theory an analysis of the way through which political agents distribute power, impose certain moral constraints on the members of a political association and make feasible specific principles of justice under conditions of imperfect compliance.

I shall return to this issue in the following chapters. For now, it is important to assess non-cosmopolitan arguments also from the point of view of their favourite principles of global justice. Contrary to the discussion on states (which as I tried to show was driven by ideal arguments when it should have focused on non-ideal issues of agency, feasibility and motivation) the opposite occurs with the analysis of principles. The non-cosmopolitan discussion on principles is non-ideal (focusing on contingent cases of unfavourable domestic conditions) when it should be ideal, i.e. addressing the issue of what kind of distributive principles are necessary in global circumstances of justice after scrutinizing international socio-economic practices. 
Let me clarify better what I mean by "ideal" in this context. Ideal principles of global justice are the ones that would emerge from a critical scrutiny of the international order at the appropriately fundamental level. The thought is here that one should not be limited to noticing the "facts" of global poverty and propose remedial principles that fail to address the issue of why there is poverty in the first place. This argument is analogous to Marx's critique of those socialists who emphasized the need to improve the conditions of workers without engaging with the forces and relations of production that led to such miserable living conditions. As Marx emphasized, "any distribution whatever of the means of consumption is only a consequence of the distribution of the conditions (or means) of production themselves". ${ }^{28}$ This point is not merely one of efficiency; i.e. Marx did not simply claim that policies addressing the problem of misdistribution at the level of production would be more successful than those tackling it at the level of consumption. Rather, as G. A. Cohen emphasized, the critique plays at a more fundamental, ideal, level: "it is a confusion to direct censure against the predictable and regular consequences of a cause which is not itself subjected to criticism". ${ }^{29}$

This means that, while arguing about ideal principles of global justice we need to consider the causes of global injustice at the appropriately fundamental level. This requires introducing in the global theory of justice a number of inferences different from the ones usually made by both cosmopolitans and non-cosmopolitans. As already pointed out, the need for specific principles of justice arises in specific circumstances of injustice, and such principles may have global scope if those circumstances are considered as being globally extended. Hence, the ideal discussion of the principles required to redress severe poverty at a global level requires justifying several claims on the injustice of global distribution in existing socio-economic practices. Such theoretical claims should be grounded on an assessment of current international practices sensitive to the relationship between absolute individual deprivation and the relative deprivation of states representing them. What we need to show, therefore, is: a) that individual absolute deprivation is linked to the relative deprivation of states

\footnotetext{
${ }^{28}$ K. Marx and F. Engels, Selected Works in Two Volumes (Vol. II, Moscow 1962) 25.

${ }^{29}$ G. A. Cohen, "Freedom, Justice and Capitalism," New Left Review 126 (1981): 13-14. See also G. A. Cohen, History, Labour, and Freedom. Themes from Marx (Oxford: Oxford University Press, 1989) 299300 .
} 
protecting them; b) that the relative deprivation of states is in turn due to an uneven distribution of power at the global level and; c) that it is impossible to abstract from such unequal distribution of power in establishing the right principles of justice in a globalized world.

The next chapter tries to show how the failure to satisfy absolute deprivation at the individual level relates to states' unequal access to power in the global sphere. It also argues that we cannot worry about absolute poverty at the individual level without worrying about relative inequality at the level of states. However, it seems that the misapplication of ideal and non-ideal categories in the analysis of global justice renders existing theoretical approaches ill equipped to develop further such an investigation. Let me first explain why.

Non-cosmopolitan accounts of a Rawlsian type consider the question of extreme poverty and resource deprivation part of the "non-ideal" theory of global justice. They claim that the lack of resources in what Rawls calls "burdened societies" does not need to preoccupy global justice theorists as such and does not therefore require principles of a distributive kind to be redressed. Rather, we have only a duty to assist societies facing unfavourable domestic conditions limiting their participation as members in a good standing to the global society of states. The difference between a sufficientarian principle of assistance and one involving an equal distribution is that while the latter has no target and cut-off point, obligations of assistance may be allocated only until burdened societies have enough as is necessary to create or preserve just political institutions. ${ }^{30}$

This justification of a duty of assistance instead of global distributive principles has both empirical and normative aspects. The former relates to a specific interpretation of the global causes of poverty and material deprivation, as well as a number of prescriptive claims as to how these could be most efficiently eradicated. The latter rests on two interdependent arguments: firstly the defence of the relevance of states and the attribution of collective responsibilities to their members and secondly a statement of the role of equality in global theories of justice. More specifically, non-cosmopolitans argue that the causes of wealth and poverty in burdened societies lie in their public

\footnotetext{
${ }^{30}$ Nagel, “The Problem of Global Justice," 119, Rawls, The Law of Peoples 76-77. I shall return to the conceptual distinction between sufficientarian and egalitarian obligations in the next chapter.
} 
political culture or in the specific religious, cultural and societal traditions that support certain background political and legal institutions, for the development of which members bear specific responsibility. Distributive principles would therefore represent an inadequate alternative since the question of global poverty is not resolved by transferring wealth from rich to poor countries without a target point but rather involves improving the political and cultural conditions that would allow burdened societies to stand up on their own. ${ }^{31}$

Cosmopolitans normally react to the empirical claim by showing how it fails to consider the impact of globalization processes on poor countries; to the normative one by emphasizing how responsibility-based arguments also weaken domestic distributive principles. On the first point, they argue that the non-cosmopolitan argument would be valid only under conditions of political and economic autarchy but not, as it happens, in the presence of trans-national economic interdependence and globalization processes under way. ${ }^{32}$ On the second point, they argue that the two combined notions of collective responsibility and respect for the autonomy of specific associative forms might also apply to families or groups in domestic societies, thus prohibiting any domestic institutional distribution of primary goods as the principles of distributive equality prescribe. ${ }^{33}$

Both points however expose cosmopolitanism to a number of potential counterarguments. Their critics could for example respond to the first (empirical) claim by saying that even if one accepts that there may be a certain degree of interference by global factors in the domestic distribution of resources this does not mean that such interference affects burdened societies negatively. One could instead argue, as libertarians usually do, that the extension of market economy contributes to the liberalization of specific forms of life, promotes a certain wealthy individualism in

\footnotetext{
${ }^{31}$ See most especially Miller, National Responsibility and Global Justice 111-62, Rawls, The Law of Peoples 118-21, Mathias Risse, "How Does the Global Order Harm the Poor?," Philosophy and Public Affairs 33, no. 4 (2005).

${ }^{32}$ See especially Pogge, World Poverty and Human Rights, Pogge, "An Egalitarian Law of Peoples."

${ }^{33}$ See Thomas Pogge, "Do Rawls's Two Theories of Justice Fit Together?," in Rawls's Law of Peoples, ed. Rex Martin and David Reidy (Oxford: Blackwell, 2006), Peter Singer, "Outsiders, Our Obligations to Those Beyond Our Borders," in The Ethics of Assistance: Morality and the Distance Needy, ed. Deen K. Chatterjee (Cambridge: Cambridge University Press, 2004).Although ultimately rejecting cosmopolitanism, Leif Wenar also notices that if Rawls had taken seriously the principle of responsibility in domestic societies he would have ended up endorsing a typical Nozickian argument, see Leif Wenar, "The Legitimacy of Peoples," in Global Justice and Transnational Politics, ed. Pablo De Greiff and Ciaran Cronin (Cambridge (MA): Mit Press, 2002), 53-76.
} 
hierarchical societies, and enhances the values of toleration thus bringing non-liberal states culturally closer to liberal ones and promoting global stability. ${ }^{34}$ Call this the "pro-global argument".

On the second (normative) claim, instead of being embarrassed by the analogous application of the autonomy and responsibility constraints to domestic societies, non-cosmopolitans could respond by emphasizing the different value of equality in domestic and global theories of justice. ${ }^{35}$ In other words, following Rawls, they might stress that relative inequalities matter more in domestic societies because of the need to preserve just institutions by guaranteeing citizens a fair treatment and equal access to public opportunities as required by the criterion of political reciprocity. ${ }^{36}$ Their alternative theory of justice is not interested in the cross-national comparison of the positions of individual subjects since the target of a duty of assistance is defined by societies' ability to sustain decent institutions. Once that goal is reached obligations of assistance cease to apply. ${ }^{37}$ Call this the "differential value of equality argument".

Assessing these two counter-arguments forces us to consider the issue of global poverty from the standpoint of ideal justice. Here it may be useful to recall a finding from the previous section: the non-cosmopolitan account is justified only on a strictly political interpretation of states as non-ideal agents of global justice. Once it has been proved: a) that from an ideal point of view there are reasons to consider other parties as relevant sources of valid claims of justice, all we need to show in addition is b) that these parties have an interest in framing certain distributive principles of justice because of the global circumstances of injustice in which they find themselves. I will further use (a) to reject the "differential value of equality argument" and elaborate more on (b) to reject the "pro-global argument".

\footnotetext{
${ }^{34}$ Friedrich August Hayek:, Law, Legislation and Liberty, the Mirage of Social Justice, vol. 2 (London: Routledge and Kegan 1976) 62-106, Jan Narveson, "Is World Poverty a Moral Problem for the Wealthy?," Journal of ethics 8, no. 4 (2005), Jan Narveson, "Welfare and Wealth, Poverty and Justice in Today's World," Journal of ethics 8, no. 4 (2005).

${ }^{35}$ One counter-argument might of course be that this is a good reason to weaken even domestic theories of justice but this is not commonly found among the kind of non-cosmopolitans we are considering who are usually keen to emphasize the relevance of domestic egalitarianism.

${ }^{36}$ Rawls, The Law of Peoples 114-16, Sangiovanni, "Global Justice, Reciprocity, and the State".

${ }^{37}$ In addition to Rawls's Law of Peoples see on this issue Freeman Freeman, "The Law of Peoples, Social Cooperation, Human Rights, and Distributive Justice ”, Nagel, "The Problem of Global Justice."
} 


\section{The differential value of equality argument}

The understanding of what justice as a virtue of social institutions requires usually marks the difference between cosmopolitan and non-cosmopolitan approaches to global poverty. Cosmopolitans are interested in the relative comparison of the position of parties across boundaries; their critics believe that the political institutions by which they are represented filter the wealth of individuals and the obligations owed to them. ${ }^{38}$ For cosmopolitans severe inequalities among individuals constitute a problem as such and equality is a value to pursue for its own sake; for non-cosmopolitans the extent of inequalities across borders is irrelevant insofar as people are able to frame and preserve decent domestic institutions. Justice, the latter argue, prescribes different things at different levels, according to the characteristics of the basic structure that constitutes a target of its principles. In domestic societies, distributive principles are rendered necessary by the background circumstances in which individuals share the benefits and burdens of social interaction; at the global level, those individuals are collectively represented by their states, which alone shape the rules of international political cooperation. Hence, the only principle of justice owed to burdened societies is a sufficientarian duty of assistance, aiming to improve not the direct living conditions of their members but the level of decency of those political institutions to which the wellbeing of individuals is owed.

Such considerations relate to the non-cosmopolitan emphasis on how distributive justice is not an allocation problem but requires designing a fair basic system of cooperation: at the domestic as well as at the global level. ${ }^{39}$ Yet it is not clear how - even accepting the non-allocative nature of distributive principles - equality between states ceases to be a concern at the international level. This is because the noncosmopolitan argument does admit a large level of cross-national interdependence, which requires designing a fair global basic structure. But this claim is in turn incompatible with a diagnosis of economic development that relies exclusively on domestic factors. If one agrees that interdependence and cooperation characterize the

\footnotetext{
${ }^{38}$ For the most articulate versions of the argument see Miller, National Responsibility and Global Justice 51-80, Nagel, “The Problem of Global Justice,” 138, Rawls, The Law of Peoples 106-18.

${ }^{39}$ This point is clarified in Freeman, "The Law of Peoples, Social Cooperation, Human Rights, and Distributive Justice ": 62-67.
} 
distribution of benefits and burdens in the global as well as the domestic sphere, we see that the analogy between the two basic structures is greater than it was initially admitted. In this case non-cosmopolitans must either grant that even the domestic distribution of benefits and burdens should be limited to the domestic analogous of a duty of assistance, or concede for the global arena something more demanding.

It is worth however considering a little more in detail the demands of justice in the domestic and global basic structure, given that it is precisely their would-be disanalogy which confers normative strength to the "differential value of equality" argument. It seems that here non-cosmopolitans fail to consider again how considerations of principle and considerations of agency interplay when assessing reciprocal obligations in global circumstances of justice. To clarify the point we should begin by asking ourselves: is it from an ideal perspective that we assess the value of an equal distribution of goods in the international sphere or is it from a non-ideal concern for the circumstances of its feasibility?

The thesis of the dis-analogy seems grounded on an assessment of the institutional mechanisms that make certain political obligations feasible and stable in the domestic sphere and on the absence of such circumstances in the global one. But recall Socrates' two stage construction of his theory of the ideal polity. Issues of feasibility and compliance become relevant only after principles of justice have been assessed from a more general relational perspective, when we ask ourselves how such principles could obtain political agency. The different way non-ideal agents operate in the domestic and global sphere could be an argument for diversifying political routes in realizing ideal principles of justice. Yet claims about principles are different from claims about how agents should act. This means that the political practice of non-ideal agents is a wholly different question from the ideal assessment of principles by subjects in circumstances of justice. Therefore, one does not change the value of equality by arguing for a change in the circumstances of its feasibility. Different circumstances will lead to different institutional routes of realizing specific principles of justice but they do not necessarily require that such principles be different.

The "differential value of equality" argument is then a typical case of would-be ideal reasoning based on a confusion between the political circumstances in which justice is realized, demanding feasibility and compliance, and the conflicting 
circumstances in which the necessity for specific principles arises. For the "differential value of equality" argument to succeed in both stages of a theory of justice noncosmopolitans must prove the relevance of the domestic and global dis-analogy not only from a non-ideal point of view, emphasizing the different political circumstances in which justice is realized but also from an ideal perspective in which the need for its principles arises.

One possible attempt to prove the domestic-global dis-analogy even from the point of view of the circumstances of justice is by emphasizing the "pro-global" argument that I introduced above. Non-cosmopolitans might insist that the distribution of goods at the global level is not subject to claims of justice because of the absence of relevant circumstances of injustice which are both globally extended and irreducible to domestic factors. The next section sketches one possible response to such an argument, further explored in the following chapter.

\section{$\underline{\text { 6. The pro-global argument }}$}

The cosmopolitan defence of global distributive principles usually starts with an intuitive appeal to the principle of equal opportunity and to the natural duty of justice to relieve human suffering. Its evidence of the extension and pervasiveness of global inequalities is often a range of facts on how many children starve every hour around the globe or how little effort it would take to cure devastating diseases in the Third world. Thomas Pogge, for example, mounts his attack against the present state of affairs by reminding us that:

the annual death toll from poverty-related causes is around 18 million, or one-third of all human deaths, which adds up to approximately 270 million deaths since the end of the Cold War.1 This problem is hardly unsolvable, in spite of its magnitude. Though constituting 44 percent of the world's population, the 2,735 million people the World Bank counts as living below its more generous \$2 per day international poverty line consume only 1.3 percent of the global product, and would need just 1 percent more to escape poverty so defined. The high-income countries, with 955 million citizens, by contrast, have about 81 percent of the global product. With our average per capita income nearly 180 times greater 
than that of the poor (at market exchange rates), we could eradicate severe poverty worldwide if we chose to try-in fact, we could have eradicated it decades ago. ${ }^{40}$

Shocking as they may be, these facts will hardly move the pro-globalist. Simply registering the moral abomination of severe material poverty around the world does not prove that his domestic account of the causes of poverty, and the non-cosmopolitan theory of justice that follows from it, are wrong. What it proves is that every individual in the world may have moral obligations to relieve absolute poverty as far as it is in his power yet such obligations need not be of a kind that requires more than sufficientarian assistance to burdened societies. The reason is not as in the previous argument that there are no agents capable of enforcing the claims of justice in a politically relevant sense, but that there are no global circumstances of injustice in a morally relevant sense. To argue this point the pro-globalist does not need to deny the presence of a global order, including political agents and institutions which go beyond domestic ones. For he can simply try to show that all the harm that cosmopolitans usually attribute to global factors can be reduced to the impact of local ones, and insofar as the current global order may be ascribed any role on poverty-related matters it will be that of historically contributing to their progressive improvement. ${ }^{41}$

What do we need to reject the pro-globalist thesis? To prove that there are relevant claims of justice - and not simply humanity - we must show that there are relevant circumstances of injustice. Call this "the test of circumstances". To prove that the kind of principles to which the claims of justice lead are principles of a distributive kind we need to show that what makes those circumstances unjust is the way in which goods are globally distributed under conditions of moderate scarcity. Call this "the test of global principles". To prove that this unjust way of distribution is globally extended we must be able to show that the circumstances of injustice escape the possibility of control of particular agents (both human and artificial ones) and constitute the outcome of spontaneous interactions and of the rules of resource allocation in a globalized market society. Call this "the test of global pervasiveness".

\footnotetext{
${ }^{40}$ Pogge, "Real World Justice," 1.

${ }^{41}$ Risse, "Do We Owe the Global Poor Assistance or Rectification?.", Mathias Risse, "What We Owe to the Global Poor," Journal of Ethics 9 (2005).
} 
In the next chapter I shall consider these issues together. I will try to show how in order to respond to the pro-globalist challenge we must establish a clear link between individual absolute deprivation at the domestic level and the relative position of their states in the global sphere. The negative impact of interactions in the global basic structure over the prospects of individual parties may be proved by showing how in global circumstances of justice access to a certain good by a specific agent or plurality of agents modifies the relative position of others. This means that cosmopolitanism will be able to make a stronger case in favour of global distributive principles if it can show how global interactions are characterized by unequal access to certain positional goods the absolute value of which depends on the relative standing of their possessors compared to each other. ${ }^{42}$ If we can identify at least one kind of primary good in the international sphere which cannot be provided through sufficientarian principles of assistance but requires an ongoing distribution we would have responded to the proglobal argument. Positional goods are relevant here since their fair distribution can only be obtained through principles of an egalitarian kind. Emphasizing the unequal distribution of positional goods in the international sphere justifies egalitarian requirements.

Now consider how the alternative approach sketched above might contribute passing the three tests mentioned: circumstances, principles and global pervasiveness. Firstly, the circumstances of injustice would be defined as the conditions under which unequal access to positional goods renders some of the agents (states) engaged in international bargaining worse-off than they would have been under an alternative arrangement. Secondly, the kind of principles required in this case would need to be principles of an egalitarian kind since an agent could only be made better off by equalizing his access to positional goods in comparison with others (even by levelling down). Thirdly, access to global positional goods does not depend on internal domestic factors: however much a state does to advance its domestic prospects, it remains vulnerable to improvement in the relative position of others. This means that any

\footnotetext{
${ }^{42}$ I shall return to the issue of positional goods and to what might constitute a positional good in the global sphere in the next chapter. The more articulate discussion of positional goods may be found in Fred Hirsch, Social Limits to Growth (Cambridge MA: Harvard University Press, 1976)., for normative explorations see Harry Brighouse and Adam Swift, "Equality, Priority, and Positional Goods," Ethics 116 (2006), Martin Hollis, "Positional Goods," Philosophy 18 (1984), Judith Lichtenberg, "Consuming Because Others Consume," Social Theory and Practice 22 (1996).
} 
attempt to introduce regulations and enforce the territorial control of single political agents is insufficient to revolve a process that is structurally dependent on what others do as well.

What cosmopolitanism needs to reject the pro-globalist argument is then to establish a link between absolute deprivation at the individual level (domestically) and relative deprivation at the level of states (globally). A similar analysis of the background circumstances under which global political interactions occur would lead to a new way of conceptualizing the principles of global justice. Non-cosmopolitan theories consider the issue of absolute material deprivation and extreme material poverty simply as an unfortunate exception in the otherwise well-ordered global society of states, not as the product of a systematic failure to assess from the point of view of distributive justice the rules of distribution of positional goods in its basic structure. Yet, as I tried to show, analysing the issue of the principles of global justice from an ideal point of view requires starting with global circumstances of injustice in production and distribution and assessing it from the point of view of all affected parties. I shall return to this new way of conceptualizing the link between poverty and inequality in the next chapter.

\section{Conclusion}

Ideal and non-ideal categories each have their place in political theory. Principles ought to be ideal, agents realistically non-ideal. The nature of states ought to be approached from a non-ideal perspective (raising the question of what kind of agents and political arrangements are necessary and available to realize the claims of justice) rather than, as with non-cosmopolitans, from an ideal perspective (treating associative relations as grounding equality-related claims). An assessment of global circumstances of justice should provide the ideal grounds of distributive equality whereas state-based associative relations are essential for making distributive obligations feasible in the non-ideal world. Once this much is clear, the controversy between cosmopolitans and non-cosmopolitans dissolves in the two-stage construction of a global theory of justice accommodating the claims of both: the need for ideal principles to consider the issue of 
global inequalities and the necessity of non-ideal agents sensitive to the political conditions of their realization.

As we already clarified, the non-cosmopolitan analysis of the principles redressing global poverty is non-ideal (restricted to cases of unfavourable domestic conditions) when it should have been ideal (raising the question of what kind of principles would emerge when assessing the circumstance of justice at the appropriately fundamental level of analysis). I have argued against sufficientarian principles of assistance, of the type non-cosmopolitans envisage, and emphasized the need for cosmopolitans to integrate in their theories a link between absolute deprivation at the individual level and relative deprivation at the level of states.

My discussion of what specific ideal cosmopolitan principles might inspire the reform of the global order and of how non-ideal agents should operate to make those principles feasible and stable was, admittedly, short. A deeper exploration of such issues is the task of the last part of this work. The aim of this second part was to illustrate the use of ideal and non-ideal categories in several discussions on global justice and open to the possibility of an alternative way of considering the ethical aims and political applications of the two-stage construction. As it now stands the global justice debate forces us to choose between the realism of statists on matters of principle and the utopianism of cosmopolitans on matters of agency. That is not a happy choice.

It is also not the right way of combining ideal and non-ideal considerations in normative theories of global justice. We should be just the opposite: cosmopolitans in matters of moral principle and statists in matters of political agency. 


\section{PART III \\ RECONCILING \\ COSMOPOLITANISM AND THE STATE}




\section{Chapter IV}

\section{Statist Cosmopolitanism: Principles}

\section{Statism: moral not just political}

This part of the thesis defends statist cosmopolitanism. I try to show how it is possible to combine the idealism of cosmopolitans in matters of principle with the realism of statists in matters of agency. In particular, this chapter defends a cosmopolitan approach to the principles of global justice. It argues that the acknowledgment of noncosmopolitan obligations to relieve absolute poverty supports a cosmopolitan conception of global distributive equality.

Let me start with an example taken from the real world. On Friday $2^{\text {nd }}$ November 2007, Adonis Musati, a former police officer from the region of Chimanimani in eastern Zimbabwe, starved to death in Cape Town while queuing at the offices of South Africa's home affairs refugee centre. ${ }^{1}$ Fellow Zimbabweans told the BBC news service that Adonis had crossed into South Africa to escape the economic crisis in Zimbabwe and was trying to obtain a temporary work permit in Cape Town. He was reported to have spent two weeks sleeping in a cardboard box, with nothing to eat, while repeatedly enquiring at the refugees' centre about the fate of his work permit. Adonis' death was discovered by his twin brother Adbell by reading news on the internet. Neither the Zimbabwean consulate nor the South African government appear to have informed the family about the event.

As the previous chapter illustrated, both cosmopolitans and non-cosmopolitans agree that letting people starve to death is wrong. The controversy arises on how to make sure that similar events do not reoccur. Adonis' case is striking in many ways. In

\footnotetext{
${ }^{1}$ See "Zimbabwean dies queuing for visa" on http://news.bbc.co.uk/go/pr/fr/-/2/hi/africa/7090730.stm, published on 2007/11/12 13:30:30.
} 
this chapter I shall explore only two crucial issues it raises. The first involves the distinction between absolute and relative deprivation and the conceptions of justice related to each of them. In the example above, absolute deprivation ultimately leads to starvation. Remedying it requires giving agents enough to have basic subsistence claims satisfied. Call this the sufficientarian conception of justice.

The above case also presents an instance of relative deprivation. Adonis has been denied a relative share in the distribution of social goods enjoyed by citizens of South Africa; he has been denied an equal opportunity to work in Cape Town. Remedying relative deprivation requires distributing to agents in the relevant position as much as that enjoyed by others. Call this the egalitarian conception of justice.

The second issue this chapter raises is that of justice to non-citizens. What (if either) of those conceptions of justice should we adopt when reflecting on the relations between citizens and strangers? On the cosmopolitan interpretation, Adonis may legitimately claim equal access to a relative share of the social means provided to the citizens or legal residents of Cape Town. On the non-cosmopolitan interpretation, Adonis may be legitimately denied an equal share of them. For cosmopolitans the relevant conception of justice to adopt when reflecting on justice to non-citizens is egalitarian. For non-cosmopolitans the relevant conception of justice to adopt when reflecting on relations between non-citizens is sufficientarian. ${ }^{2}$

As we saw in the previous chapters, both the cosmopolitan and the noncosmopolitan interpretation have been subjected to significant criticism. At the level of principle, cosmopolitans are criticized for failing to explain why citizens ought to give strangers more than "enough". Non-cosmopolitans are criticized for failing to explain why (all other things being equal) strangers ought to receive from citizens less than "as much as". At the level of agency, cosmopolitans often ask how the world's political institutions would look like if they were redesigned from scratch. To some this sounds utopian. Non-cosmopolitans ask how we could justify the institutions that we have to all affected parties. ${ }^{3}$ To others this sounds conservative.

\footnotetext{
${ }^{2}$ As already clarified in chapter II, not all cosmopolitans need to be egalitarians. However in this work I am only concerned with egalitarian versions of cosmopolitanism. If cosmopolitan principles can be reconciled with the defence of states when demanding egalitarian obligations are called into question, dealing with more moderate cosmopolitan positions should be easier.

3 Michael Blake traces a similar distinction with reference to non-institutional and institutional approaches to the analysis of global justice, see Blake, "Distributive Justice, State Coercion, and
} 
This chapter approaches these issues from an alternative perspective. It tries to defend the account of global justice that I have called statist cosmopolitanism. Statist cosmopolitanism supports the global scope of distributive equality without endorsing the usual cosmopolitan premises. It avoids starting with arguments on the moral arbitrariness of one's place of birth or with queries into how the world's political institutions would look like if they were redesigned from scratch. It articulates an alternative defence of global egalitarianism, which follows from the acknowledgment of the global scope of sufficientarian principles. It tries to show how, in global circumstances of justice, the relief of absolute deprivation at the individual level relates to the relief of relative deprivation between states. ${ }^{4}$ The realization of sufficientarian justice at the individual level demands an egalitarian distribution at the level of states.

What equality specifically requires at the global level depends of course on the aspects of relative deprivation that matter globally. I take up this issue in the second half of the chapter. I argue that the aspect of relative deprivation that matters globally is the distribution of power between states. Notice that claiming that the unequal distribution of power between states represents an important aspect of relative deprivation at the global level, is not the same as saying that the distribution of power between states is the only aspect of relative deprivation that globally matters. Fullblooded cosmopolitans might insist that the position of individuals rather than states should be equalized or that the position of individuals should be equalized in addition to that states. I am neutral on such issues. My claim about equality of power between states does not try to substitute the cosmopolitan viewpoint. I offer it as an alternative way of thinking about global justice in the absence of decisive evidence against several objections that existing cosmopolitan accounts have attracted. ${ }^{5}$

The conclusion about the need to equalize power between states is reached by means of an analogy between those positional goods that individuals in specific circumstances of justice need in equal amounts to ensure fair terms of interaction with each other, and the kind of positional good states might need in the international sphere

Autonomy," 262-66. Even though his distinction does not map onto the cosmopolitan vs. noncosmopolitan one, his own (institutionalist) approach endorses several of the non-cosmopolitan conclusions I criticize below.

${ }^{4}$ For the definition of global circumstances of justice see my chapter II.

${ }^{5}$ Some of these objections are assessed in section 4, below. I already anticipated a few of them in chapter II, sections 2 and 3 . 
in order to (also) fairly interact with each other. Positional goods are often defined as goods the absolute value of which is determined by their relative possession. ${ }^{6}$ They are comparative-relational by virtue of their very nature. How much of a positional good an agent absolutely enjoys, depends on how he fares compared to others. The argument of this chapter is that just as equal access to certain positional goods is necessary for individuals to ensure fair terms of interaction, states in the international sphere need equal power.

In global circumstances of justice, power represents a positional good. One of the features of the international order, as we know it, is that it constitutes a kind of cooperative-conflicting environment in which agents interact with each other in the absence of a hegemonic centre. States can only protect themselves from nondomination if they enjoy equal power over the making of reciprocal rules of cooperation. ${ }^{7}$ When power plays the role of a positional good, possessing it in minimally sufficient amounts requires sharing it in equal amounts. In global circumstances of justice, the only way for an agent to possess a "sufficient" amount of power is having access to "as much as" others. ${ }^{8}$ The power of an agent increases or decreases according to the relative position of others. Therefore, when dealing with power in global circumstances of justice, the only way to guarantee a threshold of sufficiency is have in place egalitarian distributive principles. ${ }^{9}$

The chapter proceeds as follows. It starts with some methodological preliminaries and definitional issues. It then clarifies the notions of absolute and

${ }^{6}$ For the definition of positional good see Hirsch, Social Limits to Growth. On egalitarianism and positional goods see especially Brighouse and Swift, "Equality, Priority, and Positional Goods."

${ }^{7}$ On the relationship between power and freedom as non-domination see Philip Pettit, Republicanism: A Theory of Freedom and Government (Oxford: Oxford University Press, 1999) 69-79.

${ }^{8}$ Emphasizing "global circumstances of justice" serves as a reminder of the conditions under which an unequal distribution of power is unjustified. In other environments hierarchies of power might be justified and indeed required. This issue will be discussed more clearly in section 5, below.

${ }^{9}$ This is a familiar intuition to any student of international relations. The issue of equality between states in IR would be framed as a question of "balance" of power. In the course of this chapter, I shall have little to say on more technical problems engaging scholars in that field, such as how we measure power, whether we consider only the distribution of "hard" power (i.e. military and economic - as in the old realist fashion) or also "soft" power (i.e. information, scientific knowledge or cultural influence - as recently argued by liberal theorists of international interdependence). For the classical realist approach see Hans Morgenthau, Politics among Nations: The Struggle for Power and Peace, 2nd ed. (New York Alfred Knopf, 1959). For a recent powerful restatement of realism see Robert Gilpin, Global Political Economy. Understanding the International Economic Order. (Princeton: Princeton University Press, 2001). For the liberal discussion on "hard" and "soft" power see Jr. Joseph S. Nye, "The Changing Nature of World Power," Political Science Quarterly 105, no. 2 (1990), Robert Keohane and Joseph S. Nye, Power and Interdependence (Boston: Little, Brown, 1977). 
relative deprivation as well as the conceptions of justice corresponding to each: sufficientarian justice and egalitarian justice. I criticize the sharp distinction usually drawn between such conceptions and argue that under certain circumstances of justice the satisfaction of sufficientarian claims requires an egalitarian distribution of relative shares. I further investigate the case of global justice and clarify that the satisfaction of sufficientarian principles at the level of individuals gives rise to an egalitarian concern at the level of states. This is because in global circumstances of justice power represents a positional good in need of being equally distributed. The rest of the chapter further articulates this statist cosmopolitan account of justice and defends equality of power between states against a number of objections.

\section{Intrinsic and instrumental egalitarianism, pure and mixed sufficientarianism}

Let me start with some methodological preliminaries. In the following pages I argue that in global circumstances of justice the claim for sufficiency at the level of individuals triggers a claim for distributive equality at the level of states. I reach this conclusion by showing how there is a special class of goods, positional goods, with regard to which equality and sufficiency cannot be kept apart. I argue that the kind of positional good that needs to be equalized in global circumstances of justice is power. Power is the "currency" of international justice.

Notice that the defence of this statist version of global egalitarianism does not necessarily lead to endorsing simple equality as a distributive ideal or as the only ideal of justice. One may claim that the possession of certain goods by relevant agents should be rendered as equal as possible along some dimension specified. This is a strong equalisandum claim, with regard to which I argue that in circumstances of global justice the relevant agents are states and that the positional good in need of being equally distributed is power. However equality of power between states can be defended compatibly with limitations imposed by other important values. In the case of global justice one such limitation may arise from the requirement that the exercise of power be legitimate, by which I mean not simply that the state is formally authorized to 
act in the name of its citizens but that it also stands up to critical scrutiny in fulfilling this task. This is a weak equalisandum claim that I also endorse in the chapter. ${ }^{10}$

Other important consequences follow from endorsing a weak equalisandum claim from a cosmopolitan perspective. The cosmopolitan position I am interested in this work defends the global scope of egalitarianism. But within egalitarianism it is common to draw a distinction between intrinsic and instrumental versions of the theory. ${ }^{11}$ An intrinsic egalitarian believes that inequality is bad in itself. An instrumental egalitarian believes that inequality is bad when it produces detrimental consequences (for example when it harms the absolutely worse-off). Now for a cosmopolitan to endorse a weak equalisandum claim will mean to embrace an instrumental version of egalitarianism. As I will try to show in what follows, noncosmopolitans who are usually keen to emphasize only the global scope of sufficientarianism should also embrace the same instrumental version of cosmopolitan egalitarianism.

Within sufficientarian views, we might distinguish between pure and mixed sufficientarianism. A pure sufficientarian will think that only sufficiency matters and that egalitarianism does not. A mixed sufficientarian will think that equality also matters when it improves the conditions of the absolutely worse-off. Mixed sufficientarianism is not so far away from instrumental egalitarianism. It is therefore surprising to see how most non-cosmopolitans have endorsed mixed sufficientarianism at home and pure sufficientarianism abroad. More specifically, they have argued that equality of relative shares matters in domestic societies but does not matter in the global sphere. As Michael Blake puts it, "only the relationship of common citizenship is a relationship potentially justifiable through a concern for equality in distributive shares". ${ }^{12}$ Or as Thomas Nagel emphasizes, "egalitarian justice is a requirement on the

\footnotetext{
${ }^{10}$ For the distinction between weak and strong equalisandum claims see Gerald A. Cohen, "On the Currency of Egalitarian Justice,” Ethics 99, no. 4 (1989): 908.

${ }^{11}$ Or as Parfit puts it between a telic and deontic versions, see Derek Parfit, "Equality and Priority," Ratio X (1997): 204-06.

12 Blake, "Distributive Justice, State Coercion, and Autonomy," 265. And also "a concern for domestic economic equality and international economic sufficiency reflects [...] a consistent and thoroughgoing concern for the liberal principle of autonomy", Blake, "Distributive Justice, State Coercion, and Autonomy," 295. Andrea Sangiovanni has also recently tried to show that "moral equality only generates a demand for social equality when we share membership in a state" and that "equality is a demand of justice only among citizens (and, indeed, residents) of a state." See Sangiovanni, "Global Justice, Reciprocity, and the State ": 3,38. A precursor argument may be found, in slightly different words in
} 
internal political, economic, and social structure of nation-states and cannot be extrapolated to different contexts, which require different standards. [W]hatever standards of equal rights or equal opportunity apply domestically; the question is whether consistency requires that they also apply globally". ${ }^{13}$

Cosmopolitans have answered this question in the positive by claiming that whatever equality requires domestically, it also requires it in the global sphere. This has led to a number of controversies on the domestic-international analogy that it is possible to avoid by simply asking a different question. That question does not involve taking a stand on the inference from domestic equality to global equality. This chapter does not try to defend the argument that if equality is justified domestically, it should also be justified globally. ${ }^{14}$ What it tries to show instead is that if sufficiency is justified globally, equality cannot be domestically restricted. To put it in different words, the kind of pure sufficientarianism endorsed so far by non-cosmopolitans is indefensible.

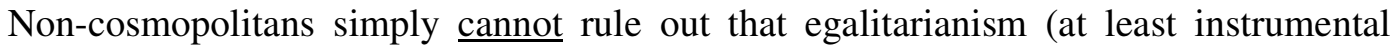
egalitarianism) has global scope. These issues are explained more in detail below.

\section{Absolute and relative deprivation}

Let us consider first the definitions of absolute and relative deprivation and the differences between them. One way to clarify such differences is by reference to those basic material goods that allow agents to pursue a functioning moral life wherever they are. An instance of absolute deprivation is nicely summarized by Pirate Jenny in Bertold Brecht's second final of The Threepenny Opera when she claims the following: "Now all you gentlemen who wish to lead us / Who teach us to desist from mortal sin / Your prior obligation is to feed us / When we've had lunch your preaching can begin". ${ }^{15}$ Jenny's comment that "Erst kommt das Fressen, dann kommt die Moral"16 suggests that in order to be able to exercise moral agency, people must, at least, be given a chance to survive. Absolute deprivation usually refers to an impediment in the

Rawls's Law of Peoples, when he discusses the difference between a (sufficientarian) duty of assistance and global difference principle, see Rawls, The Law of Peoples 115-16.

${ }^{13}$ Nagel, "The Problem of Global Justice," 114-15.

${ }^{14}$ This issue was already assessed in the previous chapter and I shall not return to it here.

${ }_{16}^{15}$ Bertolt Brecht, The Threepenny Opera, trans. Desmond Vesey (New York: Grove Press, 1964) 66.

${ }^{16}$ Literally translated: eating (gobbling) comes first, morality follows. 
satisfaction of certain basic claims - such as meeting nutritional requirements, sleeping or being in minimally good health - without satisfying which an agent could not function.

Claims for the relief of absolute deprivation arise from natural vulnerabilities easily distinguished from subjective preferences, social requirements and arbitrary desires to any good whatsoever. For example, the demands for calories, shelter, and minimal health-care constitute claims to the fulfilment of basic requirements upon which every individual has a legitimate claim in order to lead a minimally adequate and morally meaningful life. ${ }^{17}$

Claims for the relief of absolute deprivation are non-comparative. A claim is non-comparative when the nature of the claim suffices by itself to determine what is due to the claimant without concern for any other relational fact. By relational facts I mean facts regarding the position of others vis-à-vis the claimant. ${ }^{18}$ To know whether an agent has been absolutely deprived of access to such necessities we do not need to consider whether other agents with who he interacts have also been deprived of the same. We assess the situation in its own merit according to an objectively valid criterion of well-being that we employ in order to make moral judgments. ${ }^{19}$

How do we reach such an objectively valid criterion of well-being? How do we justify the validity of claims for the relief of absolute deprivation? We could say that a claim is justified a) when it is necessary, b) when it is generalizable and c) when it is necessary and generalizable by virtue of its intrinsic properties alone. Roughly speaking, a necessary claim is one the absent satisfaction of which prevents any other claim from being made. A generalizable claim is one that everyone has a reason to endorse. A claim is necessary and generalizable by virtue of its intrinsic properties alone when its necessity and generality do not depend on the validity of another claim being made.

It seems that by virtue of their intrinsic properties alone, claims for the relief of absolute deprivation are both necessary and generalizable. Claims for the relief of

\footnotetext{
${ }^{17}$ For arguments to this effect see Robert E. Goodin, Reasons for Welfare. The Political Theory of the Welfare State. (Princeton: Princeton University Press, 1988), Thomas Scanlon, "Preference and Urgency," The Journal of Philosophy 72, no. 19 (1975), Shue, Basic Rights: Subsistence, Affluence, and U.S. Foreign Policy..

${ }^{18}$ See Joel Feinberg, "Noncomparative Justice," The Philosophical Review 83, no. 3 (1974).

${ }^{19}$ Scanlon, "Preference and Urgency," 658..
} 
absolute deprivation are necessary because they constitute sine qua non claims, in other words claims whose absent satisfaction prevents any other claim (including moral claims) from being made. They are also generalizable because everyone has a reason to endorse them: i.e. everyone has a reason to want subsistence claims satisfied. ${ }^{20}$

The non-comparative nature of subsistence claims introduces us to the differences between absolute and relative deprivation. Like absolute deprivation, relative deprivation arises from a failure to access certain goods. In this case the goods in question are comparative and the relational. One's reasons for having a claim to such goods is related to the way in which other agents presently enjoy them. The claims for the relief of relative deprivation are related to the claimant's position vis-à-vis the rest of others in society and to certain features of society itself. An agent's claim over specific goods depends on the existence of a particular legal, political, cultural and economic framework, on what other agents posses and on how they interact within such framework. But what do we exactly understand by "relative" deprivation in such cases?

"Relative" deprivation may have two different meanings. On the first one "relative" indicates the relativity of a desired specific good. One example of a relative desired good might be what Adam Smith defined commodities that "the custom of the country renders it indecent for creditable people, even in the lowest order, to be without". One of Smith's examples clearly introduces us to the difference between relative and absolute deprivation as far as specific goods are concerned. A linen shirt, he argues, is, "strictly speaking", "not a necessary of life". In ancient Greece or Rome (and perhaps still in certain tribal societies) people used no linen shirts, and the lack of one would not have constituted an instance of deprivation at all. Yet he emphasizes, "in the present times, through the greater part of Europe, a creditable day-labourer would be ashamed to appear in public without a linen shirt". ${ }^{21}$ Here, being deprived of those goods would put one in a disadvantageous position vis-à-vis the rest of society. One's relative deprivation is determined by the lack of access to a share of specific social goods enjoyed by the rest of the group. But one's being deprived of those goods is relative: certainly it would be absurd to assume that one cannot survive without linen

\footnotetext{
${ }^{20}$ Arguably, even someone who is on a voluntary hunger strike for some ideological or religious reason is endorsing the validity of claims for the relief of absolute deprivation, although not his own but the claims of those whose cause his hunger strike serves.

${ }^{21}$ Adam Smith, The Wealth of Nations: Iv-V, ed. Andrew Skinner (London: Penguin, [1776-1783] 1999) 465 .
} 
shirts or that everyone in the world is entitled to an equal share of them independently of where they live.

The second, more important, way of understanding "relative" in "relative deprivation" may indicate the relativity of the means through which a desired good is acquired. In competitive environments political power, trade opportunities, educational resources, employment availability, returns for exchanging what one owns, legal guarantees on property, are means that determine an agent's ability to access specific goods. An agent's need for such means arises not simply because of what he does taken singularly but also because of how other agents relate to one another within a specific institutional framework. In a market economy for example where the improved conditions of life of one group of people determine an increased demand for some particular good and a consequent rise in its price, access to such good will be precluded to those whose wages are not regulated to match market fluctuations. ${ }^{22}$ The agent suffering from a reduction of his purchasing power will therefore be deprived of the means through which this particular good could be acquired. Yet this deprivation is only relative. It would not arise in a planned economy where, say, prices are determined by state institutions or in a subsistence economy where people consume what they find in nature, neither would it arise independently of how other agents act within a particular institutional framework. I will return to this point when assessing what kind of means allow us to conceptualize relative deprivation globally understood.

In the most general terms the notion of relative deprivation has been defined as a situation "where people possess less of some desired attribute, be it income, favourable employment conditions or power, than do others". ${ }^{23}$ Relative deprivation is determined by the lack of access of some to a relative share enjoyed by others. The satisfaction of claims for the relief of relative deprivation depends on the relations that the claimant entertains with other agents and on the circumstances in which they interact. This is also why such claims are often associated to citizenship entitlements. If everyone else in a particular society enjoys certain benefits, the claimant would be disadvantaged by being arbitrarily deprived of a relative share of such benefits.

\footnotetext{
${ }^{22}$ See, for empirical evidence Amartya Sen, Poverty and Famines: An Essay on Entitlement and Deprivation (Oxford: Oxford University Press, 1983).

${ }^{23}$ Peter Townsend, Poverty in the United Kingdom: A Survey of Household Resources and Standards of Living (Berkeley: University of California Press, 1979) 31-89.
} 
Contrary to the non-comparative claims corresponding to absolute deprivation, claims arising from relative deprivation are comparative. Such claims refer to an impediment of a member of a certain group to access goods and opportunities shared by the rest of it.

\section{$\underline{4 .}$ Egalitarian and sufficientarian justice}

Absolute and relative deprivation are often thought to involve two different conceptions of justice, conducive to different kinds of principles. Remedying absolute deprivation leads to a conception of justice that we have called sufficientarian. Sufficientarian justice requires guaranteeing individuals' the satisfaction of their justified claims for the relief of absolute deprivation. Sufficientarian justice appears to be non-comparative in form: for example, in order to decide how much is enough to save a hungry man from starvation we do not need to consider the position of other agents, for example how much food other people consume in the same time. ${ }^{24}$

The relief of absolute deprivation requires the fulfilment of basic subsistence claims. It gives rise to an obligation to provide agents with "enough" as is necessary for them to function. Sufficientarian justice involves non-comparative principles. In order to determine how much is enough for you to avoid being absolutely deprived, it is not necessary to consider how much others have. It also seems to involve non-relational responsibilities: if you lack $\mathrm{O}$ and $\mathrm{O}$ is necessary for you to survive, there are prima facie obligations to provide you with $\mathrm{O}$ regardless of the relationship you entertain with the agent in a position to help. It is hardly surprising that a consensus has emerged on the universal validity of obligations to relieve absolute deprivation, regardless of the associative relationship in people we stand to each other. Such non-relational obligations are generated by the intrinsic validity of the claims for the relief of absolute deprivation that we emphasized above. ${ }^{25}$

\footnotetext{
${ }^{24}$ The cases in which this is not so, i.e. when positional goods are involved, will be examined shortly.

${ }^{25}$ For a justification of non-relational duties to relieve absolute deprivation following different strategies (rights-based, need-based, consequentialist, contractarian) see Goodin, Protecting the Vulnerable: A Reanalysis of Our Social Responsibilities, Jones, Global Justice : Defending Cosmopolitanism, Miller, National Responsibility and Global Justice, Rawls, The Law of Peoples, Shue, Basic Rights: Subsistence, Affluence, and U.S. Foreign Policy.
} 
On the other hand, remedial principles for relative deprivation lead to a more complex conception of justice: egalitarian justice. According to this second conception, what deserves to be called just or unjust is the way in which goods are divided. Plato defined it as that "which distributes to each what is proper according to this principle of [rational] proportions" and called it "political justice". ${ }^{26}$ In Aristotle, egalitarian justice is "that which is shown in the distribution of honour and money or such other assets as they are divisible among members of a community". ${ }^{27}$ The idea of agents related to each other in the modes of accessing or enjoying certain goods is analytically contained in the claim for a proportional distribution of relative shares. In order to know how much to distribute of what, we must have some idea of who are the relevant parties concerned as well as where a specific distribution ought to occur. I shall return to this issue when examining what egalitarian justice requires in a global world. For now, notice the different form that claims for the relief of relative deprivation assume. If agent $\mathrm{A}$ lacks $\mathrm{O}$, and A's modes of accession or enjoyment of $\mathrm{O}$ partly depend on another agent's (call it $\mathrm{B}$ ) modes of accession or enjoyment of $\mathrm{O}$, then we will need to settle a way for regulating access to $\mathrm{O}$. We shall do so by recurring to some criteria for the distribution of benefits and burdens between A and B taking into account of the equal demands of both agents in circumstances of justice. Thus, egalitarian justice is comparative in form and the responsibilities it generates are relational: they hold among agents reciprocally dependent on the relative position of one another.

How do egalitarian justice and sufficientarian justice relate to each other? One view holds that they are logically independent: sufficientarian justice is a matter of having "enough" whereas egalitarian justice is a matter of having "as much as". ${ }^{28}$ Being absolutely deprived is a matter of poverty. Being relatively deprived is a matter of inequality. Sufficientarian justice and egalitarian justice may therefore be analysed independently from each other. They generate different kinds of principles: non-

\footnotetext{
${ }^{26}$ This account of justice as equality of proportions is proposed by Plato both in Republic (Rep 433b) and in Gorgias (508a, see also 465b/c), see Plato, The Collected Dialogues of Plato Including the Letters. ${ }^{27}$ Aristotle, Nicomachean Ethics, trans. J. A. K. Thomson (London: Penguin, [unknown] 2004) 118.

${ }^{28}$ Harry Frankfurt, "Equality as a Moral Ideal," Ethics 98, no. 1 (1987).. For a recent restatement of the doctrine of sufficiency see Roger Crisp, "Equality, Priority, and Compassion," Ethics 113 (2003).. I focus here only on some aspects of these accounts, for a powerful recent critique and an attempt to defend a mixed version of the doctrine of sufficiency see Paula Casal, "Why Sufficiency Is Not Enough," Ethics 117 (2007).
} 
comparative principles in the first case and comparative principles in the second one. ${ }^{29}$ Moreover, as we have seen, they are often thought to trigger different kind of responsibilities: non-relational responsibilities in the sufficientarian case, relational responsibilities in the egalitarian one. ${ }^{30}$

But let us consider more carefully whether the principles required to relieve absolute deprivation and the principles required to relieve relative deprivation are always as different as they initially appear. This is the same as asking whether sufficientarian justice and egalitarian justice do indeed rest on wholly separate grounds. Consider the following. One typical case of absolute deprivation is the lack of food leading to starvation. One typical case of relative deprivation is the absence of an equal opportunity to benefit from access to specific goods: say an equal opportunity to work, equal enjoyment of certain social benefits or an equal chance to access the means through which this good is obtained more generally speaking. When discussing justice to non-citizens, those who argue for maintaining the separateness of the remedial principles corresponding to each, usually emphasize that absolute deprivation may be relieved via sufficientarian principles securing access to "enough" basic subsistence goods. Yet they also emphasize that this does not imply satisfying relative claims via distributive principles of equality. ${ }^{31}$

There are circumstances however, in which the attempt to distinguish between sufficientarian principles and egalitarian principles appears ill considered. Taking seriously sufficientarian justice is often likely to require the application of egalitarian principles. Consider one typical case of absolute deprivation: that of starvation. Starvation occurs when people do not have enough to eat. One obvious solution to the problem might therefore appear recurring to non-comparative principles increasing food supply to agents in need. This is clearly also what sufficientarian justice, with its emphasis on giving people enough as is necessary to raise their well-being above a minimum threshold, would require.

However, starvation may not always occur because of a shortage in food. There may be plenty of food available but particular groups in society may not have access to

\footnotetext{
${ }^{29}$ Parfit, "Equality and Priority," 206-07.

${ }^{30}$ See especially David Miller, "Holding Nations Responsible" Ethics 114, no. 2 (2004).

31 Blake, "Distributive Justice, State Coercion, and Autonomy.", Miller, National Responsibility and Global Justice, Nagel, “The Problem of Global Justice.”, Rawls, The Law of Peoples. The next section explains why some non-cosmopolitans reject the global scope of egalitarian principles.
} 
the means necessary to acquire food: be those means employment, educational opportunities required to access certain market benefits or simply purchasing power. What is even more interesting; the worsening in the social position of such groups may relate to the material advancement of others. Absolute dispossession is linked to relative deprivation, and poverty may result from larger social inequalities. In this case, the use of non-comparative principles to realize sufficientarian justice will be out of place. What is required in all those cases is equalize access to the means through which a sufficient amount of end-use goods (i.e. food) could be obtained.

This view of the link between absolute and relative deprivation seems confirmed by the analysis of some of the greatest famines of the past century. ${ }^{32}$ In all those cases, what led particular groups of people to starvation was not a shortage in food availability but rather their being left behind while other groups advanced economically in new political circumstances. In the case of the 1943 Bengali famine, for example, difficulties arose not as a result of shortage in rice (harvest was relatively similar to that of previous years) but due to modifications in exchange entitlements and the emergence of groups relatively deprived of the means through which food was acquired. More particularly general inflationary pressure and a shortfall in the food release due to war-panic combined with an unequal increase of incomes and purchasing power of people engaged in war-related activities. Those employed in the military and civil defence sector could earn more, exerting strong demands on food and leading to an increase in its price which others employed in less-profitable activities were unable to match. ${ }^{33}$ People starved because they were absolutely poor, yet they became absolutely poor due to the emergence of relative inequalities.

The Bengali famine case is by no means an unfortunate exception. Furthermore, the conclusions drawn from it do not lend themselves to easy generalizations on the domestic nature of the link between absolute and relative deprivation - as those defending a purely sufficientarian approach to global justice often imply. ${ }^{34}$ Very

\footnotetext{
${ }^{32}$ Sen, Poverty and Famines.

${ }^{33}$ Ibid. 76-77.

${ }^{34}$ See especially Rawls's use of the Bengali famine example in Rawls, The Law of Peoples 106-18. and those who endorse Rawls's sufficientarian approach to global justice, e.g. Blake, "Distributive Justice, State Coercion, and Autonomy," 271, 94, Freeman, "The Law of Peoples, Social Cooperation, Human Rights, and Distributive Justice ": 50-52, Miller, "Collective Responsibility and International Equality in the Law of Peoples.", Nagel, "The Problem of Global Justice," 119, Reidy, "Rawls on International Justice, A. Defense," 311.
} 
recently (April 2008), the United Nations Food and Agricultural Organization reported a $70 \%$ increase in world food prices within one year only. It also lamented its detrimental contribution to growing political instability, constant impoverishment of vulnerable sectors of society and violent hunger riots all over the world: from South Asia (Bangladesh or Philippines) to West Africa (Ivory Coast, Cameroon, Senegal); from Eastern Europe (Ukraine and Russia) to South America (Haiti, Argentina, Mexico). ${ }^{35}$ Here, just as in the famine case mentioned above, the increase in prices was not determined by a shortage in food availability. On the contrary, the total cereal crop in 2007 has been 1.66 billion tonnes, the largest witnessed ever, and some $89 \mathrm{~m}$ tonnes bigger than the harvest of the previous year, which already was a record. ${ }^{36}$ As one of the World Food Programme's executive directors declared to the press: "we are seeing more urban hunger than ever before [...] we are seeing food on the shelves but people being unable to afford it". 37

Here, again, the problem at the root is not absolute lack of access to food but growing relative inequalities. Take the following example. One of the reasons for which people in poor countries cannot afford bread, is that people in richer countries are eating more meat. Indeed, one of the major causes for the recent increase in global food prices is reported to be the dietary shift that has recently occurred among growing urban middle classes in the largest rice and wheat exporting countries such as China and India. ${ }^{38}$ The fact that people in these countries can now afford to buy meat and other dairy products means that farmers keep more animals than they previously did and feed larger amounts of cereals to them, significantly contributing to an increase in the demand for cereals and therefore to a consequent increase of price. This affects not just the domestic poor which, one might plausibly argue, can always be assisted through domestic distributive schemes and other public policies). It affects also the

\footnotetext{
35 For some of the evidence, see "Asian states feel rice pinch" on http://news.bbc.co.uk/go/pr/fr//2/hi/south asia/7324596.stm, published on 2008/04/03; "Riots prompt Ivory Coast tax cuts" on http://news.bbc.co.uk/go/pr/fr/-/2/hi/africa/7325733.stm, published on 2008/04/02; "Rice prices hit Philippines poor" on http://news.bbc.co.uk/go/pr/fr/-/2/hi/business/7330168.stm, published on 2008/04/06; "Egyptians hit by rising food prices" on http://news.bbc.co.uk/go/pr/fr//2/hi/middle_east/7288196.stm, published on 2008/03/11.

${ }^{\mathrm{S}}$ The data are drawn from The Economist, see "Cheap no more", published on Dec 6th 2007.

${ }^{37}$ Reported in "Riots prompt Ivory Coast tax cuts", cit. above.

${ }^{38}$ Reported in "Cheap no more", The Economist, cited. The problem are not just India and China though, but also the levels of meat consumption in developed countries, see George Monbiot, "Credit crunch? The real crisis is global hunger. And if you care, eat less meat", in: http://www.guardian.co.uk/commentisfree/2008/apr/15/food.biofuels/print
} 
poor in other parts of the world, where food accounts for at least half of the consumerprice index and whose states rely on trade with those major exporting powers to obtain necessities such as rice, grain and wheat. In a global market economy, the relative improvement in material conditions for some has significant consequences not only for domestic members of vulnerable social classes but also for the citizens of some of the poorest states. States such as Bangladesh (reportedly facing its major food crisis since the 1974 famine), Nepal, Benin or Niger, which depend on India or China for their food supply, are the first to suffer the consequences of fluctuations in the domestic markets of those countries.

Consider another frequently cited reason for the increase of food prices: ethanol consumption. It is often remarked how the use of ethanol to produce biofuel diverts farmer investments from basic agricultural products to maize (used to produce ethanol), rendering those products scarcer and more expensive resources. ${ }^{39}$ Here again the modification of relative life standards in one part of the world has significant consequences for the poor in other parts of the world. The increase in demand for ethanol as fuel for cars in places like the United States, modifies the patterns of agricultural production and trade. Thus, relatively affluent countries where cars constitute the favourite means of transport may condition the levels of food consumption and threaten the subsistence threshold of poor citizens in the poorest states.

Empirically, it is clear that the effects of such modifications in societal style and environmental standards cannot be tackled through domestic measures, which are unable to prevent globally determined inequalities. But the issue at root is deeper. These examples show that claims for the relief of absolute deprivation are related to the non-fulfilment of claims for the relief of relative deprivation. Poverty and inequality appear closely intertwined. The non-cosmopolitan distinction between the scope of sufficientarianism and the scope of egalitarianism does not capture those cases. Pure sufficientarianism merely requires that we make sure that people have "enough", it does not tell us anything about the need for some to obtain "as much as" others: in fact it explicitly rules this out by saying that distributive equality is only justified within the

39 See "IMF head gives food price warning", published on http://news.bbc.co.uk/go/pr/fr//2/hi/business/7344892.stm, published on 2008/04/13. 
state. It also does not consider that some may not be able to obtain "enough" precisely because they have not had "as much as" others. Yet, as the cases above show, sufficientarian principles should be integrated with egalitarian ones. In global circumstances of justice, a number of claims for the relief of absolute deprivation would not arise if claims for the relief of relative deprivation were satisfied.

This thought sheds a different light on the distinction between remedial principles for absolute deprivation and remedial principles for relative deprivation with regard to the scope of justice. It shows that one cannot restrict egalitarian principles to domestic circumstances and advocate pure sufficientarian principles for the global sphere. It also invites a different type of analysis of the links between sufficientarianism and egalitarianism. On this alternative analysis, claims for the relief of absolute deprivation are closely related to claims for the relief of relative deprivation. There may still be a conceptual difference between them. But the difference emerges only if we analyse the problem from the point of view of the "urgency" of the demands they generate, not from the point of view of which conception of justice is more global than the other. ${ }^{40}$ If we consider the issue of absolute deprivation purely in terms of what people ought to receive in order to lead a minimally decent life, it is clear that claims for the relief of absolute deprivation constitute the most pressing types of demands and pure sufficientarianism appears as a generally adequate account of justice. However, if we consider the distinction between "absolute" and "relative" deprivation, "comparative" and "non-comparative" principles from the point of view of what generates absolute destitution in global circumstances of justice the answer appears more complex.

Maintaining a strong distinction between poverty and inequality in all these cases seems question begging in various respects. If absolute poverty is linked to the emergence of relative inequalities it would of course not be very efficient to try and address the former yet leave the latter unchallenged. Some sufficientarians recognize this point when they claim that equality might prove to be "the most feasible approach

\footnotetext{
${ }^{40}$ See for arguments trying to emphasize the distinction between the two and stressing the moral priority of urgent claims Barry, "Humanity and Justice in Global Perspective.", T. D. Campbell, "Humanity before Justice," British Journal of Political Science 4, no. 1 (1974)..
} 
to the achievement of sufficiency". ${ }^{41}$ But the main point is not one of efficiency or feasibility. The main point is one of moral rigour. We would not be taking really seriously claims for the relief of absolute deprivation if we ignored the kind of relative social inequalities that might in turn produce absolute deprivation. The greatest failure of pure sufficientarianism advocated at the global level is that it places exclusive moral weight on non-comparative principles. Non-cosmopolitans restrict the scope of comparative principles to domestic circumstances of justice and advocate noncomparative ones at the global scale. This restriction, as I tried to show, is unjustified. Non-comparative principles do not allow taking into account the links between absolute and relative deprivation and issues such as the relative advancement of certain groups in society vis-à-vis others or the relative position of certain dependent states compared to ones that are more powerful.

I shall return to this last point in the next section. For now let me stress again that by maintaining a strong distinction between sufficientarian and egalitarian justice we would not simply be acting in the least efficient way possible. We would also be acting in a morally deficient way. We would worry about the morally objectionable nature of absolute deprivation but fail to consider the morally objectionable nature of the social, political and distributional mechanisms that lie at its heart. What is problematic here is not the feasibility or efficiency of pure sufficientarianism. What is problematic is that its lack of theoretical sophistication cultivates moral hypocrisy.

Sufficientarian principles cannot be considered a completely separate issue (with an entirely different domain of application) from egalitarian ones. A different kind of moral assessment is required. One ought to engage more seriously with the structural roots of absolute deprivation and address the distributive impact of economical and political mechanisms through which subsistence claims arise, the way they relate to each other, assume a determinate status within given social standards and follow patterns of relative social inequality and political injustice, both domestic and international. Highlighting the ways in egalitarianism should integrate sufficientarianism demands making a choice between two different ways of

${ }^{41}$ Frankfurt, "Equality as a Moral Ideal," 22. It should be pointed out however that those who apply sufficientarian principles to global relations explicitly rule out even this weaker point; they simply consider sufficientarian and egalitarian justice to apply to different realms of justification, as the quotes above show. 
conceptualizing the links between absolute and relative deprivation, poverty and inequality.

The first one considers absolute deprivation and the principles generated by sufficientarian justice as non-comparative principles of assistance to people in extreme need. It confers global scope to sufficientarianism yet insists on the domestic scope of egalitarianism. The second one, which I am trying to suggest, considers claims for the relief of absolute deprivation linked to claims for the relief of relative deprivation. In the first case, the analysis of poverty occurs within a framework which ignores the background structure in which global inequalities to arise. In the second case, remedying absolute deprivation requires tackling relative deprivation and addressing social inequalities: inequalities in income and means of accessing basic material resources but also inequalities of power and opportunities for political participation more broadly conceived. From the perspective of the former, absolute and relative deprivation, sufficientarianism and egalitarianism are radically distinguished and have different domains of application. From the perspective of the latter, they differ in the relative urgency of their claims but they ought to generate related remedial principles. It follows from this relatedness that if sufficientarianism has global scope, egalitarianism ought also to have global scope.

\section{$\underline{5 . \text { Equality of power }}$}

We seem to have succeeded in showing that in circumstances where agents cooperate and compete to access the means for obtaining certain goods, sufficientarian justice requires principles of an egalitarian kind. The case of people living in different states, who - through their states - interact with one another in a global market society provides a concrete example of such circumstances. ${ }^{42}$ Arguing that in this case global sufficientarianism requires global egalitarianism supports an alternative defence of cosmopolitanism, which need not rely on assumptions about the moral arbitrariness of one's place of birth or on an attempt to imagine how the world's political institutions

\footnotetext{
42 I emphasize "at least in some cases" because it is possible to imagine abstract situations in which equality and sufficiency conflict. I do not focus on these cases however. Given the instrumental version of my defence of equality, which grants the moral importance of sufficiency-related claims, it should be clear that the usual objections to those who defend equality as intrinsically valuable do not apply.
} 
would look like if they were redesigned from scratch. ${ }^{43}$ But what does global egalitarianism require in positive terms?

Our attempt to link sufficientarian justice to egalitarian requirements relies on the assertion of a clear relationship between absolute and relative deprivation. As we emphasized, the claims of absolute deprivation generate non-comparative principles whereas those of relative deprivation generate comparative principles. Linking noncomparative principles of sufficiency to comparative principles of equality raises a number of questions regarding the ways in which comparative principles operate, what they distribute or fail to distribute and among whom. Since egalitarian principles are grounded on a comparative conception of justice and require an equal distribution of relative shares, they can only be further articulated in positive by specifying what "equal" distribution amounts to within a group of agents reciprocally involved in a joint enterprise of the kind we specified.

On closer inspection, it may seem that the relationships of individuals across the world are simply not such that they allow us to specify "what" concretely each of them is relatively deprived of, how well they fare compared to one another and especially how to account for what should be globally equalized. ${ }^{44}$ Once we go beyond the most obvious absolute levels of deprivation, identifying what exactly remedying relative deprivation requires in a culturally and politically plural world becomes problematic. Indeed what counts as relative deprivation for individuals in one place, may not be that relevant in another. Relative deprivation, remember, triggers distributive obligations when some members of a group are unable to access benefits enjoyed by the rest of them, thus ending up in a disadvantaged position in society. But how do we make sense of this claim in the global sphere, where what counts as relative - as opposed to absolute - deprivation of individuals across countries is much more difficult (if not impossible) to specify ? $^{45}$

\footnotetext{
${ }^{43}$ For another attempt to justify global egalitarianism without endorsing similar premises see Charles R. Beitz, "Does Global Inequality Matter?," Metaphilosophy 32, no. 1\&2 (2001). Beitz's account however focuses on substantive equality of opportunity between individuals worldwide and is therefore unable to avoid the objections considered below.

${ }^{44}$ See Miller, National Responsibility and Global Justice.

${ }^{45}$ One might object here that this is what the capability metric developed by Sen, Alkire, Robeyns and others aims to capture. Notice however that the capabilities' metric is used to measure poverty, not inequality. In other words, the capabilities approach is helpful to discover whether people in different countries have fallen below a threshold under which they are unable to function. In fact Sen emphasizes that establishing such threshold must take into account community variations, see Amartya Sen, "A
} 
The objection above was already introduced in the second chapter under the name of "metric objection". ${ }^{46}$ One way to answer it might be to emphasize that, instead of attempting to equalize specific goods that all individuals in the world should enjoy we should focus instead on their ability to make use of whatever goods allow them to be functioning moral agents, wherever they are. As one advocate of cosmopolitanism puts it, "global equality of opportunity requires that persons (of equal ability and motivation) have equal opportunities to attain a number of positions commensurate to an adequate standard of living". ${ }^{47}$ One might still complain here that the expression "commensurate to an adequate standard of living" is too vague to respond to the global metric of equality objection. ${ }^{48}$ Yet that is not the basic problem. The basic problem, more constructively, is that by emphasizing the "adequacy" of living standards we have still left unanswered the question of why an egalitarian rather than sufficientarian type of principle is globally required. We have failed to explained why it is always important for people in one place not merely to have "enough" for themselves but also "as much as" people in another. In other words, the risk with such an answer is that it expresses nothing distinctive about the egalitarian agenda. Even more seriously, it undermines the purported link between absolute and relative deprivation that we are trying to justify.

Is there a way out of this dilemma? I think there is. It requires however bracketing the attempt to substantively equalize the position of individuals across the world and concentrate on the relations between the states representing them.. ${ }^{49}$ That is to say, that the only way for us to compare the position of individuals across the world

Sociological Approach to the Measurement of Poverty: A Reply to Professor Peter Townsend," Oxford Economic Papers 37, no. 4 (1985). But the metric objection applies to the issue of inequality rather than simple poverty: it requires us to identify a currency for measuring relative goods in need of being equalized rather than asking how it is possible to establish a global poverty line. Individualist defences of global egalitarianism appear particularly vulnerable here, Beitz for example in his instrumental defence of egalitarianism that I mentioned above acknowledges the relevance of the critique, see Beitz, "Does Global Inequality Matter?," 102.

${ }^{46}$ Miller, National Responsibility and Global Justice $56 \mathrm{ff}$.

47 Simon Caney, "Cosmopolitan Justice and Equalizing Opportunities," Metaphilosophy 32, no. (1/2) (2001): 130 .

${ }^{48}$ For this critique Miller, National Responsibility and Global Justice 64. See also Gillian Brock, "Egalitarianism, Ideals and Cosmopolitan Justice," Philosophical Forum 36 (2005): 16-19.

${ }^{49}$ Kok-Chor Tan has a similar argument but addressed to equality between nations rather than states. See Tan, Justice without Borders : Cosmopolitanism, Nationalism, and Patriotism 107-34. However Tan's defence is grounded on the value of self-determination, mine on the necessity of equalizing certain positional goods (such as power) in global circumstances of justice. Moreover, Tan believes in the possibility of equalizing relative shares between individuals worldwide, a premise that cannot escape the metric of equality objection stated above. 
is to see them as citizens of specific states, then in turn compare those states to one another and raise the further question of what can and ought to be equalized between states. We would then have answered the metric objection.

Consider the argument against global egalitarianism that $\mathrm{I}$ have just summarized. The first premise in the objection - as its stands - notes that distributive equality requires comparing relative shares of individuals across the world. The second premise denies that such comparison is ever possible given the influence domestic institutions and particular cultures exercise on how individuals value goods across boundaries and on the use that is made of them. Hence, one might quickly conclude, distributive justice can only have domestic scope. Equality only makes sense when it is possible to identify a way of distributing goods that are equally valued, equally desirable for all affected parties in the world, and equally in need of being shared.

Now if in the argument above we consider the position of states rather than individuals, the case in favour of global egalitarian justice becomes more plausible. Moreover, we are able to respond to the 'metric of equality' objection. Indeed once we shift focus from the comparison of the relative position of individuals across countries to the comparison of the position of states we discover an analogous concept to domestic individual opportunity in the international sphere: state power. If individuals need equal opportunities in the domestic sphere in order to interact fairly with each other, states in the international sphere need equal power. In global circumstances of justice power represents a positional good, relative access to which requires to be equalized if the conditions of the absolutely deprived are to be improved.

It is important to emphasize that we are discussing power in "global circumstances of justice". In fact it is possible that in other kinds of environments hierarchies of power would be justified. In certain contexts (universities, businesses and so on) we would not think the unequal distribution of power between professors and students or between managers and secretaries problematic. In those latter examples there would be a clear hierarchy serving the purpose of a specific collective activity for the functioning of which an uneven distribution of power is required. Interactions between states in the global sphere are different. An unequal or hierarchical distribution of power would here lead to the domination of some by others and would therefore 
undermine the goal of a society of states, as an association of free and equal agents. Let us consider why.

Let us start with a general definition of power. First, power is a dispositional concept; it refers to a capacity to yield certain outcomes. Locke's early definition of power conveys this idea: to have "power", he writes, "is to be able to make, or receive" (and one could add resist) "any changes". ${ }^{50}$ Power therefore consists in the ability to do certain things, independently of whether the agent chooses to actually exercise it or not. ${ }^{51}$ Second, power is a relational concept. An agent's successful capacity to exercise power depends on there being other agents upon which such power is exercised. An agent's impediment to exercise power depends on there being some other agents able to resist the change. In the widely accepted definition of Dahl, power refers to "subsets of relations among social units such that the behaviours of one or more units (the responsive units, $\mathrm{R}$ ) depend in some circumstances on the behaviour of other units (the controlling units, C)" ${ }^{52}$ Third, power is a comparative ability: an agent is powerful or powerless according to how he fares compared to another with more or less abilities. Lemuel Gulliver, for example, is powerful in the island of Lilliput, yet powerless in that of Brobdingnag not because anything in him has changed but because of how he fares compared to the natives of those countries.

This last point is perhaps the most important for purposes of our discussion. Hobbes makes it very clear in Leviathan when he emphasizes that what motivates the struggle to obtain more power in the international sphere is not "that a man hopes for a more intensive delight than he has already attained to, or that he cannot be content with a moderate power". ${ }^{53}$ Rather, he argues, it is because "he cannot assure the power and means to live well, which he hath present, without the acquisition of more". 54

In global circumstances of justice, states compete with each other through global market structures but also cooperate to establish certain rules of global

\footnotetext{
${ }^{50}$ John Locke, The Second Treatise on Civil Government and A Letter concerning Toleration, ed. J. W. Gough (Oxford: Blackwell, 1946), 111. For the "resistance" addition see Steven Lukes, Power : A Radical View, 2nd ed ed. (Houndmills, Basingstoke, Hampshire : New York: Palgrave Macmillan, 2005) 69.

${ }^{51}$ Ibid. 70.

${ }^{52}$ Robert Dahl, "Power as the Control of Behavior," in Power, ed. Steven Lukes (New York: New York University Press, 1986).

${ }^{53}$ Thomas Hobbes, The Leviathan, R. Tuck ed. (New York: Cambridge University Press, 1991) ch. XI.

${ }^{54}$ Ibid.
} 
interaction. In such circumstances, power represents a positional good. The only way to enjoy sufficient power is possess it in equal amounts. The relative distribution of power is more basic than its absolute possession or lack of possession, indeed the relative distribution of power is the only thing that matters. "Enough" can only be secured by enabling agents to have "as much as" (analytically and not just empirically speaking).

To understand what it means for power to be a positional good in a competitive environment consider the following example. In Sicily, both the state and Mafia exercise power over people's life. Clearly there is a sense in which the state exercises some power, the police is able to put fines on drivers if they fail to respect traffic laws, people can bring each other into court and so on. Yet the state is not "as powerful as" the Mafia, indeed the existence of a police apparatus does not withhold the owners of shops from paying part of their monthly returns to the Mafia simply because they have been asked to do so. For the state, having a "sufficient" amount of power when it comes to how that sufficient amount is comparatively exercised does not matter that much. Only how the power of state and that of Mafia fare in relation to one-another determines the absolute value of each. In the case of a positional good such as power, "enough" is not enough without it being equal.

\section{Power as a global positional good}

Why is "power" a global positional good? Let me press further the analogy with individual positional goods. In competitive environments between individuals, positional goods represent means the possession of which enables an agent to access other desired things. What determines the absolute value of positional goods is how much one has compared to others. So for example, in the case of a typical positional good such as education, the value of, say, a master degree in the job market depends on whether other people have PhDs. In the case of resources for legal representation in court, the value of one's defence depends on the merits of the counter-part. ${ }^{55}$ In the cases of positional goods, equalizing the position of parties (even by leveling down) appears unobjectionable if it is designed to ensure a fair competition. Equality of positional goods is necessary to ensure that the rich and privileged do not accumulate

\footnotetext{
55 These examples are taken from Brighouse and Swift, "Equality, Priority, and Positional Goods," 475.
} 
benefits at the expense of the poor, and that trade-offs do not occur at the expense of vulnerable agents. In the case of positional goods the only way to have enough and fairly interact with others, is to have as much as them. Absolute deprivation can only be avoided if agents are not made relatively worse-off.

Notice that power in the international sphere represents a kind of positional goods that all states have reason to want equalized. Power represents a mean through which certain outcomes are obtained. It gives states the ability to interact with each in the international society of states. Power is the kind of positional good that all states regardless of their political culture - need in equal amounts to establish fair international regimes from which their position partly depends. In global circumstances of justice, where political decision-making is essentially based on states bargaining with each other, equal distribution of power is a necessary feature in order to obtain agreements fairly arrived at. The establishment of just terms of trade benefiting not just safely rich countries but also more poor and vulnerable ones, the ability to coordinate in the exercise of state's coercive capacity, the capacity to sign international conventions on non-proliferation, crucially depend on there not being power inequalities which would otherwise bias the solutions emerging from international rounds of negotiation.

One should be careful not to understand the claim for equalizing state power in a merely formal guise. Clearly formal guarantees - principles such as "pacta sunt servanda" as well as other founding principles of international law - matter enormously. But consider again the analogy with domestic litigation and the positional goods (i.e. legal representation) involved in that case. In the domestic case it is important that individuals do not merely enjoy certain formal legal opportunities but have access to an equal share of resources (i.e. equally good lawyers) in order to be able to take advantage of such opportunities and interact in fair terms with each other. So too in the international case, the formal guarantees of international law (nonintervention, respect of state-sovereignty, recognition of international treaties, conventions and agreements) would be meaningless unless they were backed up by a substantive equal empowerment of states, allowing them to make effective use of such guarantees. 
Consider, for example, the impact of power inequalities in the establishment of agricultural trade agreements and tariff barriers for poor countries. Agriculture in developing countries counts for the 40 per cent of the GDP, 35 per cent of exports and 70 per cent of employment and, as we have seen, is one of the most sectors that renders them most vulnerable to trade liberalization. ${ }^{56}$ However, evidence from all the recent GATT/WTO negotiation rounds shows that powerful states have been able to shape the agricultural trade agenda in ways that increased subsidies and protective barriers when this served the interests of domestic farmers and agricultural industries, while ignoring persistent requests from developing countries to reduce tariffs for products in which they had comparative advantages. Even when the need for "Special and Differential Treatment" for developing countries was formally recognized (as in the Doha Declaration) this led to no concrete practical measure (other than longer implementation periods) and the only changes were rhetorical. ${ }^{57}$

Powerful countries deploy various strategies to shape the WTO trade agenda at their own advantage. They play developing states against each other by promising to some bilateral or regional negotiations and benefits that they deny to others. They combine material resources and informational advantage in negotiation and litigation meetings that only few representatives from developing countries can afford to attend. They bribe or threaten vulnerable states to obtain their support when challenged on specific issue-areas. They take advantage of diplomatic networks or expensive legal resources to bring poor states in legal court. They form partnerships with large multinational corporations to prevail in settlement negotiations over trade disputes. They use financial coercion and liberalization discourses to elide development-related issues; or they deploy extra-legal tools that developing countries do not dispose in order to find convenient ways of interpreting WTO rules and exemptions. ${ }^{58}$

\footnotetext{
${ }^{56}$ Joseph Stiglitz and Andrew Charleton, Fair Trade for All (Oxford: Oxford University Press, 2005) 120.

${ }^{57}$ Ibid. pp. 59-65.

58 See John Braithwaite and Peter Drahos, Global Business Regulation (New York: Cambridge University Press, 2000), Gregory Shaffer, "Power, Governance and the Wto: A Comparative Institutional Approach," in Power in Global Governance, ed. Michael Barnett and Raymond Duvall (Cambridge: Cambridge University Press, 2005), Richard H. Steinberg, "In the Shadow of Law or Power? ConsensusBased Bargaining and Outcomes in the Gatt/Wto," International Organization 2, no. 56 (2002), Joseph E. Stiglitz, Globalization and Its Discontents (London: Penguin, 2002).
} 
Without a substantive effort to equalize the position of all states, power asymmetries generated by relative inequalities will always condemn poor and vulnerable states to a position of subordination. They will always be subtly constrained to endorse whatever more powerful actors determine on their behalf, even if they receive "enough" generous assistance from them, as sufficientarian justice would require, or rather precisely because of that. Instead of empowering in equal measure all affected parties, instead of requiring that every agent in the democratic society of states have access to as much of the means required to equally perform their role vis-à-vis their citizens and vis-à-vis each other, sufficientarian justice creates dependence and cultivates deference. It preserves a hierarchy of donors and recipients; it does nothing to narrow the gap between powerful states and powerless ones. The first progress in relative terms, dictate the rules of the game and make decisions on how much ought to be given to everyone else; the latter keep at a respectful distance and should gratefully look forward to whatever goods they will be supplied with, if they have been compliant.

Earlier we saw that a pure sufficientarian approach to global justice displays a lack of theoretical sophistication when it undertakes to eradicate absolute dispossession yet refuses to consider its relationship with relative inequalities. Whilst avoiding to look beyond non-comparative principles, that lack of sophistication - we emphasized could easily lead to moral hypocrisy. But as we can now see, that lack of theoretical sophistication also threatens to legitimize an international order in which the relatively weak are taken advantage of from the safely rich, it runs the risk of having nothing distinctive to say against an international regime made of coercive offers, egoistic promises and implicit threats. Ultimately, that lack of theoretical sophistication threatens to absolve the subtlest forms of international oppression.

\section{$\underline{\text { 7. Objections }}$}

Relative deprivation can only be countered by means of egalitarian principles. In the global sphere, egalitarian principles demand that all states be equally empowered. Power, we stressed, constitutes the currency of egalitarian justice at the global level. But what does equal empowerment of states amount to? I shall limit myself to mentioning two different ways through which we can further articulate the notion of 
equality between states, two dimensions along which all states have reasons to want to be "empowered", independently of their respective political and social cultures. These hardly constitute an exhaustive list of potential articulations of the concept of state power. I point them out merely by way of countering the weight of arguments from political and cultural diversity, which seek to undermine the case for global egalitarianism by stressing the complexity of equality and its apparent irreducibility to a single set of goods considered valuable across communities.

All states, as I have mentioned above, have equal reason to want to be empowered, notwithstanding their diversity in life style, historical development, political traditions, and so on. Just like individuals, states are concerned with freedom as non-domination. Just like individuals, they can be secure from domination if they enjoy equal power. And just like in the individual case equal access to positional goods is necessary not to be dominated, in the case of states equal power plays an analogous role. Military power is what enables states to do just that, offer territorial protection to all their members and guarantee that they do not become an easy target of unjustified foreign intervention. Needles to say, inequalities in the distribution of military power constitute the greatest obstacle to the establishment of a just peace in times of war, and to the preservation of peace when this has finally been achieved. But the presence of great military potentials may also implicitly threaten countries who might be tempted to resist the will of powerful states or refuse to be manipulated in international bargaining situations. As the ambassador of a small, developing country chairing a WTO negotiating group, declared to the press, after having passionately defended US interests against challengers: "they have options that smaller countries do not have...my god look at what the US did in Iraq". 59

There seems to be plausible prima facie reasons in favour of the equalization of military capacity, perhaps proportional to territorial extension and population size and ideally accomplished by levelling down. ${ }^{60}$ But being secure from external threat is usually not all there is for individuals. It is also not all there is for states. We think that

\footnotetext{
${ }^{59}$ Cited in Shaffer, "Power, Governance and the Wto: A Comparative Institutional Approach," 135.

${ }^{60}$ Notice that an attempt to equalize military capacity for the sake of international peace is precisely what was spontaneously undertaken by the major superpowers during the Cold War (although in that case containment was achieved - somewhat contradictorily - through a race to the top). This however confirms the impression that in practice, independently from the differences in political culture, all states have a reason to seek equal military power.
} 
individuals are unable to take advantage from the formal rights available to them if they cannot access the positional goods allowing them to exercise those rights effectively. Notice that the same occurs with states. The formal recognition of international legal standing for states means little in the absence of the material conditions allowing them to exercise sovereignty effectively. Hence, we come to the second dimension along which the notion of state power can be articulated in the international arena: economic power. The case for the economic empowerment of vulnerable, underdeveloped states is all too clear if one considers the recent history of international economic and financial agreements. As I already pointed out, significant evidence from the last round of WTO negotiations suggests that in all relevant areas, from agricultural subsidies to industrial tariffs, from the regulation of migratory fluxes to the distribution of property rights, powerful states have been able to shape the agenda, dictate economic priorities and secure themselves a number of trade privileges at the expense of the worse-off. ${ }^{61}$ Here again, the case for equalizing economic power, by setting up institutional schemes for an equal distribution of wealth between powerful and powerless states would seem straightforward.

There may be objections to this proposal. The first is almost certainly bound to remind us that states might abuse their power. By asking to distribute an equal amount of wealth or military capacity to each of them, we might end up strengthening all sorts of dictatorial regimes, contribute to human right violations and so on. Remember however that at the beginning of this paper I endorsed a weak equalisandum claim. I argued that equality is one value among many and that it should be promoted compatibly with those others. I also argued that equalizing the power of weak states is necessary in order to integrate rather than replace other important principles of international law (non-proliferation, respect for international treaties and conventions, compliance with human right conventions). Egalitarian justice does not conflict with these principles, if anything it guarantees that they are applied fairly and not just when it serves the interests of powerful states as it now happens all too often. To reject egalitarian principles in the global sphere because there is a chance that some states misbehave, is analogous to arguing against domestic distribution on grounds that some citizens might end up being criminals. Surely, the answer to that threat in the domestic

${ }^{61}$ Stiglitz and Charleton, Fair Trade for All, Stiglitz, Globalization and Its Discontents. 
sphere is not to dismantle distributive regimes, the answer is that those are different issues and should be addressed following different kinds of principles. Statist cosmopolitanism does not object to that, neither does it require equality to be the only principle to promote while discussing relations between states. ${ }^{62}$

Another objection might be to say that the position of weak states in the international arena is not constrained by the relative power of others. One could plausibly argue that domestic features such as population growth, social employment policies, cultural and religious values, affect seriously the way in which different countries develop and the relative wealth they accumulate. However, critics of global egalitarianism who defend global sufficientarian principles tend to overemphasize those domestic features at the expense of theoretical sophistication. Examples of isolated societies living in autarchy and reaching specific societal standards thanks to their autonomously developed political culture, are elegantly deployed either to undermine claims for an egalitarian distribution of relative shares across borders. Alternatively, they recur to emphasize how all countries deserve their respective relative wealth and remind us that there is no obligation to share it equally with others beyond sufficientarian levels. ${ }^{63}$

I do not mean to dismiss the illustrative value of those examples. Yet, one must be wary of the dangers of over-simplification, because autarchic-society-examples lead to an unwarranted partition of the moral world which says that one ought to recognize the global scope of sufficientarian principles but is unwilling to grant how egalitarian ones might follow from that acknowledgment. I do not mean to deny the relevance of domestic factors or arguments on national responsibility and collective desert. The point I am making is a different one and one could raise it independently. Where groups of people are related to one another through patterns of exchange and trade, where the advancement of some societies modifies the relative ability to access certain goods of others, there seem to be plausible, independent, reasons for wanting to establish a fair system of political cooperation placing distributive constrains on the economic development of powerful countries, even when it is well deserved. To return to

${ }^{62}$ Since the aim of this work is to defend cosmopolitan egalitarianism, exploring these alternative principles would fall outside its scope. For a good additional discussion of the principles of cosmopolitan political justice see Caney, Justice Beyond Borders - a Global Political Theory.

${ }^{63}$ See the use of such examples in Blake, "Distributive Justice, State Coercion, and Autonomy," 290-92, Miller, National Responsibility and Global Justice 68-75, Rawls, The Law of Peoples 117-18. 
simplifying examples: if Rich prevents Poor from being able to access bread at prices Poor could previously afford, it seems that Poor can press a claim for an equal share of the means through which bread is accessed without further need to enquire about whether Rich deserves to be Rich and whether he acquired his wealth through inheritance, theft, winning the lottery or honest work. Likewise, it seems that Rich is under an obligation to equally share such means with Poor without need for Poor to explain him which gods he worships, what he does in his leisure time and whether he is thinking of having another child rather than put his savings in an investment bank . (Of course Poor has all the more reason to demand equal means of accessing bread if Rich has promised that under no circumstance would he let Poor starve but I will not press that point again). ${ }^{64}$ The important issue to bear in mind is that when the equality of certain positional goods (or power, in the case of states) is required to ensure fair terms of interaction between agents who would otherwise exploit relative inequalities to take unfair advantage of each other, a number of additional discussions on desert, responsibility, choice and luck could be safely reserved for another time.

\section{Conclusion}

In this chapter, I investigated the link between absolute and relative deprivation with regard to the issue of global justice. I argued that global responsibilities to avoid absolute deprivation trigger global responsibilities to remedy relative deprivation. I emphasized that taking seriously sufficientarian justice at the level of individuals requires the application of egalitarian principles at the level of states (at least). I further articulated this claim by defending the idea of power as the currency of global egalitarian justice and by demanding that state power be globally equalized.

The principles of statist cosmopolitanism I have outlined do not exhaust the range of topics one should consider when assessing global justice. This chapter did not attempt to settle questions related to the legitimacy of external interference in the case of domestic political injustice. It did not address issues related to compensation for past violations of human rights, decolonization or some such. It also did not ask how the

${ }^{64}$ Rich and Poor here are individuals but even if we took them to be collective agents, i.e. states, the point would remain the same. 
world would look like if there were no states at all, or where individuals would like to live if they could speak from behind the veil of ignorance. Statist cosmopolitanism reflects on the impact of relative power inequalities on the protection that weak states are able to offer their own citizens and considers the issue one that can be raised in its own right. A society where agents interact on the basis of exploitative offers, implicit threats and false promises, and which endorses an overarching conception of justice likely to cultivate moral hypocrisy and political servility is not a just society. This chapter has shown that the validity of that judgment does not depend on where the boundaries of such society lie. 


\section{Chapter V}

\section{Statist Cosmopolitanism: Agency}

\section{Cosmopolitanism: political not just moral}

We seem to have established the moral desirability of cosmopolitan principles at the ideal level. Whether such principles are also feasible in non-ideal circumstances remains to be seen. The moral claims of cosmopolitanism are such that they require the transformation of political institutions. The present chapter defends the normative relevance of the state for a cosmopolitan transformation of political institutions. ${ }^{65}$ It tries to show how states provide the unique associative sphere in which cosmopolitan principles obtain political agency, may be legitimately enforced and cohesively maintained.

Broadly speaking, political agency obtains when it is both feasible, i.e. relevant political, legal and social mechanisms are in place to operate the necessary changes in the system, and when the outcome of political action is stable, i.e. it has a good chance to survive without disrupting existing social ties and it generates a sense of the collective that is likely to endure throughout time. Politics is an essential element for both requirements. In the first case politics should be understood in a more institutional sense, as the sum of processes and agents through which specific goals affecting citizens' public interactions are achieved. In the second case, politics should be understood in a more civic sense: stability may be secured only if the relationship between citizens on matters of common concern is one of constant participation rather than mutual exclusion and if the development of collective institutions accomplishes individual emancipation.

${ }^{65}$ Throughout the chapter I will use the terms of state and political community interchangeably. An exact definition of "political community" is provided in section IV. 
The following pages explore the background circumstances under which political agency with a cosmopolitan scope could be considered successful. By background circumstances, I understand those societal (both cultural and political/legal) conditions under which political agency is feasible, and the outcome of political action is stable. ${ }^{66}$ There are three ways of conceptualizing the background associative circumstances in which political obligations could be allocated. The first account, what I shall call the "civil society model of the political community," is characterized by both ethical and political universalism. It claims that there are universal moral constraints bearing equally on individuals worldwide (ethical universalism) and that all sets of institutions are equivalent in their desirability (political universalism). ${ }^{67}$ No special normative importance is attached to particular associative schemes either from an ethical perspective, regarding what individuals rightly owe to each other, or from a political one, determining what kinds of agents are most suited to uphold the universal claims of justice. The civil society model understands the polity as a set of collective institutions and practices instrumentally relevant for regulating conflicting interests in accordance with certain principles of justice considered valid for everyone. If those institutions failed to perform their designated social role, they could easily be replaced by alternative sets, enabling new ways of cooperating in view of reciprocal advantage.

By contrast, the second account, what I will call "the political community as a large family," is characterized by both ethical and political particularism. It emphasizes that a shared language, history and public political culture confer unique values upon particular associative relations and ground special obligations among members that do not exist between them and outsiders. ${ }^{68}$ Its ethical particularism resides in the claim that the fundamental principles of ethics do not derive from abstract considerations about human nature or individual dignity, but are limited by particular relational facts

\footnotetext{
${ }^{66}$ By effective I mean that the institutions enabling their allocation are stable and likely to be supported by citizens. Throughout the chapter I use the terms "effective" and "stable" interchangeably.

${ }^{67}$ Thomas Pogge's analysis on cosmopolitanism and sovereignty contains some clear statements of both types of claims. See Thomas W. Pogge, "Cosmopolitanism and Sovereignty," Ethics 103, no. 1 (1992). Similar arguments are also made by O'Neill, Bounds of Justice 174-85. and Beitz, "Cosmopolitan Liberalism and the States System," 124-6.

${ }^{68}$ Statements of this view may be found in Thomas Hurka, "The Justification of National Partiality," ed. Robert McKim and Jeff McMahan (New York: Oxford University Press, 1997), Alasdair Macintyre, Is Patriotism a Virtue?, Lindley Lecture (Lawrence: University of Kansas, 1984) 9-12, Miller, On Nationality 49-80, Margaret Moore, The Ethics of Nationalism (Oxford: Oxford University Press, 2001) 25-51, Walzer, Spheres of Justice: A Defence of Pluralism and Equality ch 2.
} 
characterizing social life. ${ }^{69}$ Different types of human relations trigger different types of obligations so that what we owe to, say, members of our family, colleagues or fellowcitizens, is different, at the basic level, from what we owe to people with whom we do not stand in any particular relation. Similarly, the political particularism of the family model resides in the claim that the value of institutions embodying particular relations cannot be reduced to what instrumentally serves the aggregative interests of individual members. Rather, by taking part in the establishment and historical development of specific social institutions members create collective goods rendering those institutions unique and worthy of preservation. ${ }^{70}$

Both models of the polity are familiarly flawed. The civil society model is generally derided for its political universalism, ignoring the peculiarity of different forms of political association, failing to engage its members' disinterested concern for the collective and giving rise to social instability and "political disaffection". ${ }^{71}$ The family model is derided for its ethical particularism, blind to whatever claims of outsiders demand political transformation, neglecting the distinctiveness of individuals with its emphasis on social identification and leading to potentially exclusionary practices. Building on the strengths of the two models whilst avoiding those familiar weaknesses in them, I shall here argue for a third, alternative, conceptualization of the polity.

My model will be characterized by ethical universalism and political particularism. Emphasizing the relevance of specific historical circumstances for the allocation of cosmopolitan obligations, I shall firstly distinguish between universal

\footnotetext{
${ }^{69}$ A similar definition of ethical particularism is provided by Miller, On Nationality 50. The way in which ethical particularism is defined by the authors mentioned above is somewhat different from the one referred to in certain areas of moral philosophy and associated with scholars such as Jonathan Dancy and John McDowell. The latter form of ethical particularism denies the existence of moral principles altogether and argues that moral judgment does not consist in the application of principles to cases. See for example Jonathan Dancy, "Ethical Particularism and Morally Relevant Properties," Mind 92 (1983). Miller, Macintyre and Walzer, however, would disagree with this scepticism on the existence of moral principles. Their question would not so much be whether there are moral principles at all, but rather how we determine their content - i.e. whether we start with an abstract account of individual human beings or with some more particular features of human association. Here I am only concerned with the first type of ethical particularism.

${ }^{70}$ For a more elaborate statement of this view, see Michael Walzer, "The Moral Standing of States: A Response to Four Critiques," Philosophy and Public Affairs 9, no. 3 (1980).

71 On "political disaffection" as symptomatic of this model of society see most recently Claus Offe, "Political Disaffection as an Outcome of Institutional Practices? Some Post-Tocquevillean Speculations," in Political Disaffection in Contemporary Democracies. Social Capital, Institutions and Politics., ed. T. Mariano and G. R. Montero (London: Routledge, 2006).
} 
normative reasons and particular motivational sets. Then I shall try to justify the role of particular political communities in making cosmopolitanism both feasible and stable. Two features of political cooperation appear very relevant in this respect: mechanisms that allow the imposition of mutual political constraints upon members; and a basis for mutual agreement which progressively leads citizens to sympathize with cosmopolitan goals. By focusing on the relevance of the political for the associative conditions in which cosmopolitan obligations obtain agency, I shall illustrate how each of the previous accounts overemphasises an element entirely absent in the other - the possibility of a shared collective end in the civil society model and dynamics of political agonism and social transformation in the family one. Thus, the conditions in which political agency may be feasible and stable are lacking in both of them. Instead they are substituted by two kinds of orthodoxy: the orthodoxy of law in the civil society model, and the orthodoxy of cultural identity in the family one.

The third way of conceptualizing public associative interactions combines features of the civil society and family models and clarifies conditions under which political agency would be feasible, and the outcome of political actions would be stable. These features emphasize key requirements of the democratic tradition in political theory: popular sovereignty and civic education. As I try to show, in the absence of the first one - legitimate decision-making mechanisms - any political initiative would be unfeasible. Yet, in the absence of the second - a historically developed willingness to comply - any achieved outcome would be unstable. Popular sovereignty, on the one hand, allows cosmopolitan obligations to enter a collective deliberative process enabling the transformation of political institutions in accordance with cosmopolitan goals. Civic education, on the other hand, complements this process by progressively familiarizing citizens with cosmopolitan virtues embodied in cultural and historical practices that are, for the most part, understood and shared. Both, I suggest, are indispensable conditions if we want social justice to be more than a cosmopolitan manifesto: popular sovereignty for cosmopolitanism to become feasible in the first place and civic education for it to be maintained. These ideas are explored in the following sections. 


\section{Civil society or large family?}

The civil society and family models of political community seem to rest normatively on mutually exclusive premises. The civil society model is often understood as an atomistic one. Its subjects are mutually indifferent and self-contained units, each with a multiplicity of needs and wants and an independent plan on the best way to promote their satisfaction. Interactions are based on enlightened self-interest, the mode of cooperation relies on calculations of mutual benefit and membership in the association is partly, or entirely, voluntary. The worth of the association can be instrumentally reduced to the sum of the advantages derived by its members. Collective institutions are supposed to exercise their functions within the limits of the technical purpose they serve, letting citizens promote their own good in their own way.

The large family model adopts a holistic approach in order to clarify the background associative circumstances in which an altruistic concern for the common good - missing in the civil-society model - is thought to be present. A family is a selfcontained unit, whose members identify with it not for instrumental reasons, such as taking advantages from the benefits it provides, but because participating in its organic life is constitutive of their own identity. Where membership in the civil society model is a quasi-arbitrary feature, sharing a set of collective cultural and historical practices is in the family account a source of internal gratification, something through which individuals are fully realized. Members in the family model recognize each other as both the authoritative source and the subjects of collective institutions, consider the unique mode of their interactions to constitute a common good and are jointly engaged in cooperative practices aiming to promote, not only the welfare of existing members, but also that of future generations.

Traditionally the civil society model has been criticised for its atomistic features, failing to engage its members' disinterested concern for the collective and leaving the public sphere open to potential risks of corruption, accumulation of power and the degeneration of political institutions in specific historical circumstances. Benjamin Constant was among the first to voice such a critique. The danger, he emphasized, is that "absorbed in the enjoyment of our private independence and in the pursuit of our particular interests we shall surrender too easily our right of participation 
in political power". For this reason he claimed, "the work of the legislator is not complete when he has simply brought peace to people. Even when people are content, there is still much to do. Institutions must achieve their moral education". ${ }^{72}$

Many cosmopolitans implicitly adopt the civil society model of political association while insisting for a radical reform of existing political institutions to make them compatible with principles of global justice. Typically, they argue for the need to create supra-state or trans-national bodies able to mediate between the conflicting requirements of sovereign states and realize the principles of cosmopolitan justice. ${ }^{73}$ However, the issue of how such institutions could, once established by legislative means, be historically maintained - i.e., the question of what motivates people to comply with duties assigned to them - is seldom raised. But as Rousseau once reminded, "no constitution will ever be good and solid unless the law rules the citizens' hearts. So long as the legislative force does not reach that deep, the laws will invariably be evaded". ${ }^{74}$

But "how can men's hearts be reached?",75 The civil society model of political association is able to engage their interests, their reciprocal respect - at best their moral imperatives. Institutions maintain strength and stability as long as they promote justice, and justice is promoted as long as everyone does his fair share in the cooperative scheme. However, justice, "even of the utmost integrity," is not enough to motivate everyone's disinterested concern for the collective, because "justice, like health, is a good which one enjoys without feeling it, which inspires no enthusiasm, and the value of which one feels only once it has been lost."76 The real difficulty, Rousseau thought, is not so much creating institutional responsibilities, but rather to fix them in a way that limits the possibility of defection and preserves whatever achievements emerge as a result of cultural and political practices with which members progressively identify.

\footnotetext{
72 Benjamin Constant, "The Liberty of the Ancients Compared with That of the Moderns," in Political Writings, ed. Biancamaria Fontana (Cambridge: Cambridge University Press, 1988 (1819)), 327-8.

${ }^{73}$ See, for example, Caney, "Cosmopolitan Justice and Institutional Design: An Egalitarian Liberal Conception of Global Justice.", Richard Falk, Law in an Emerging Global Village: A Post-Westphalian Perspective (Ardsley: Transnational Publishers, 1998), David Held, Democracy and the Global Order: From the Modern State to Cosmopolitan Governance (Stanford: Stanford University Press, 1995), Raffaele Marchetti, Global Democracy: For and Against. Ethical, Institutional, and Social Perspectives on Political Inclusion (London: Routledge, 2008), Pogge, World Poverty and Human Rights 169-95.

${ }^{74}$ Rousseau, "Considerations on the Government of Poland," 179.

75 Ibid.

${ }^{76}$ Ibid.
} 
Hence the importance attributed to civic education and to social participation, as well as the emphasis placed on the members' mutual recognition in their collective enterprise.

The family-model of political association takes these objections to the civil society model seriously by combining them in an alternative account of the nature of political association. It starts with assuming a set of specific associative circumstances in which members develop social habits that make them more willingly comply with communal obligations. By emphasizing the collective source of mutual obligations, the family model minimizes the possibility of defection not by threatening to punish, but by appealing to deeper feelings of associative loyalty, historical ties to a particular sphere and reciprocal solidarity. Loyalty is here understood as a widespread sense of commitment to the well-being of the community. It is a commitment independent of the respective benefits to individual members in specific historical situations and does not merely arise out of concern for possible sanctions. The collective goods produced by community life, its traditions, culture and distinctive institutions provide a source for mutual recognition, significantly shape the identity of members and constitute a stable basis for social cooperation that citizens would want to defend even in the presence of an external threat.

Consider the case of Poland which, as Rousseau reminds, would have been overwhelmed by its Russian neighbours at various historical moments if feelings of associative loyalty and the prevalence of collective attachments over individual interests had not led its citizens to rise, even to the point of sacrificing their lives, in defence of the distinctiveness of their communal form of life. As Rousseau puts it: "it is national institutions which form the genius, the character, and the morals of a people, which make it be itself and not another, which inspire in it the ardent love of fatherland founded in habits impossible to uproot, which cause it to die of boredom among other people in the midst of delights of which it is deprived of its own."

One might of course object that the family model of political association overstates the extent to which people are, as a matter of fact, motivated by communal attachments of a Rousseauean kind. Yet, just from a causal inspection of newspapers, it seems that the number of people willing to make significant sacrifices for preserving their community's self-determination is large enough to justify the claim that patriotism

\footnotetext{
${ }^{77}$ Rousseau, "Considerations on the Government of Poland," 183.
} 
is not simply the product of an old-fashioned, nostalgic mind. But this attitude does not seem to prevail towards trans-national institutions, however well designed or deeply integrated. As one author puts it: despite being subject to similar globalizing forces, "citizens of Western democracies are able to respond to these forces in their own distinctive ways, reflective of their 'domestic politics and cultures'. And most citizens continue to cherish this ability to deliberate and act as a national collectivity, on the basis of their own national solidarities and priorities." 78

\section{Normative reason and motivation}

The family model of political association seems then to provide a thicker account of moral motivation than the civil society one. It speaks to the majority of people's hearts, as Rousseau would have put it, and appeals to the principles of moral psychology in explaining how specific associative circumstances develop important ties of fellow feeling and reciprocal solidarity that institutions need in order to obtain stability. However, even the family model is not without problems. Its shortcomings emerge more clearly if we consider the moral theory that it derives from a set of empirical observations on the circumstances of motivation - ethical particularism.

Ethical particularists insist that universalism relies on an inadequate account of moral motivation. By grounding obligations on a universal view that requires people to abstract from particular sentimental ties or special inclinations, a cosmopolitan, universalistic view of morality makes particularly demanding claims with which fallible individuals may not be able to cope. More specifically, particularists emphasize that most people find it difficult to abstract from their social relationships and comply with universal principles only because it is their duty to do so. As one author puts it: "it seems unlikely that rational conviction can carry the weight required of it, except perhaps in the case of a small number of heroic individuals...For the mass of mankind, ethical life must be a social institution whose principles must accommodate natural sentiments towards relatives, colleagues, and so forth, and which must rely on a

\footnotetext{
${ }^{78}$ See the discussions on empirical reactions to the European Union or NAFTA in Will Kymlicka, Politics in the Vernacular - Nationalism, Multiculturalism, and Citizenship (Oxford: Oxford University Press, 2001) $320 \mathrm{ff}$.
} 
complex set of motives to get people to comply with its requirements - motives such as love, pride, and shame as well as purely rational conviction."79

Ethical particularism thus emerges as an alternative view of morality which considers obligations embedded in particular social institutions, customs and a given political culture. It claims to offer a more appropriate account of moral motivation and attempts to reconcile ethical principles with community habits that members develop by taking part in specific associative practices. But one needs here to distinguish carefully between two systematically separate questions. The first is related to the source of ethical obligations. The second goes back to the circumstances of their performance. The fact that in certain circumstances I am happier to comply with a particular duty than in others does not make those circumstances or my happiness a guiding principle for justifying my obligations, as an ethical particularist would claim. This is because the reasons for which I ought to perform a certain way are a wholly separate question from the way in which I happen to perform today. Put in a different way: how you do something is not the same as what you ought to do. One can easily agree with particularists that, apart from a few moral heroes, it matters to a great number of people whether duties can be combined with natural and social inclinations, and whether discharging obligations can be done in a way that also brings satisfaction. This does not mean, however, that satisfaction is the source of moral agency, just as it does not mean that feelings of love, mutual sympathy or consideration for some particular agents are the only reasons for which we act in an ethically justified way. If we only focus on existing social inclinations that motivate imperfect moral agents to ground all our obligations, we might end up marginalizing those with whom we do not share any strong associative bond and run the risk of basing the state on deeply exclusionary practices.

Having traced a distinction between the source of obligations and the way of executing them, it seems perfectly possible i) to accept that particular associative ties are essential for developing compliant attitudes in people, and at the same time ii) to reject the need for an alternative theory to the universalist cosmopolitan one. One can share with cosmopolitanism the concern for universal obligations and still insist that we need particular communities to get a motivational grip on people by activating their

\footnotetext{
${ }^{79}$ See Miller, On Nationality $57-58$.
} 
shared understandings. Similarly, one can concede to particularists that many people are more easily motivated by feelings of love, sympathy or mutual trust than by respect for universal laws without also conceding that this is the only, or indeed the most appropriate, foundation of moral duties.

The fact that empirically, in given circumstances, people undertake their obligations more willingly is very important. But the fact that it is important does not mean that it is always right. Of course, it also does not mean that those circumstances are arbitrary and one can change them at will, as some cosmopolitans might emphasize. Instead, empirical observation tells us that, if we are interested in the efficient allocation of certain duties, we should realize that imperfect moral agents will discharge their obligations differently, in different associative circumstances. Hence, we end up with a view that justifies a universalistic ethics with regard to the source of our obligations but makes concessions to particularism as far as one's circumstances of moral motivation are concerned. This is also the view I advance in the next section while arguing for the conditions in which political agency succeeds. For now, let me consider some objections to the idea that I have just expressed, i.e. that one can distinguish between normative reason and motivational sets to overcome the flaws of the civil society and family models of political association and still make sense of some relevant intuitions underpinning each of them.

One possible objection to this idea is that distinguishing between normative reason and motivation leads to a sort of "moral schizophrenia" introducing incoherence, fragmentation and disharmony in the structure of our ethical judgments. ${ }^{80}$ Consider the following case. The ethical universalist knows that the worth of his actions is due to his adherence to universalistic moral laws. Yet, he realizes that pure moral virtue might not be common or reliable enough in ordinary people and that feelings of love, friendship and mutual solidarity are more likely to motivate imperfect moral agents than the mere obligation to comply. Critics have pointed out that the ethical universalist is here likely to face the following dilemma. Either he should recognize that his own moral view is distorted or incomplete because it does not make space for social inclinations, which might contribute to increasing the value of moral actions, or allow such social

\footnotetext{
${ }^{80}$ For one such objection to ethical theories emphasizing the distinction between normative reasons and motivation, see Michael Stocker, "The Schizophrenia of Modern Ethical Theories," The Journal of Philosophy 73, no. 14 (1976).
} 
inclinations to enter the process of moral deliberation thus corrupting the universalist's pure initial motives.

Is there a way out of such dilemma? Interestingly, Kant once emphasized the distinction between normative reason and motivation in response to Schiller's similar objection that his account of moral obligation involved a "monastic frame of mind" which left out people's dispositions and natural tempers entirely. Writing during the Terror of the French Revolution, Schiller had argued in several papers that abstract moral imperatives needed to be reconciled with natural inclinations and social habits if morality were to realize itself in the empirical world. This would help man avoid being either a "savage", with his feelings ruling over the principles, or a "barbarian", with his principles destroying his feelings. ${ }^{81}$ With these ideas, he intended to criticize Kant's account of morality, which seemed to exclude the possibility of morally cultivating inclinations because of the risk of corrupting the purity of categorical imperatives. Kant's surprising answer was that there was no principled disagreement between him and Schiller on this point. Indeed, he denied the possibility of an irremediable conflict between duty and motivation by tracing an implicit distinction between the source of obligations and the manner of their execution. As Kant put it, "I am unable to associate gracefulness with the concept of duty, by reason of its very dignity." However, when it comes to the duty's "temperament" and the way in which a moral subject develops his resolve, "a slavish frame of mind can never occur without a hidden hatred for the law" whereas only in the presence of a "joyous frame of mind" one can also gain a love for virtue and definitely acquire it. ${ }^{82}$

Thus, it seems perfectly possible to defend ethical universalism without conceding that a rightful action, if complemented by a positive motivation other than that of acting from duty, would lead to a moral failure. After all, insisting that an action has moral worth when it is performed from the motive of duty alone is not the same as saying that such an action suddenly becomes worthless if it is also supported by other positive motives. Therefore, an ethical universalist can still maintain that an action holds moral worth when determined by the motive of duty. This does not necessarily

\footnotetext{
${ }^{81}$ Friedrich Von Schiller, Letters Upon the Aesthetic Education of Man (Montana: Kessinger Publishers, [1795] 2004) 7-10.

${ }^{82}$ Immanuel Kant, Religion within the Boundaries of Mere Reason and Other Writings (Cambridge: Cambridge University Press, [1793] 1998) 39-40.
} 
commit him to the claim that a similar state of affairs is preferable to another where cooperative inclinations are present as well. ${ }^{83}$ But if, as particularists suggest, we ground all our obligations on feelings of love, friendship and solidarity, how could we cope with states of affairs marked by the absence of cooperative inclinations yet in need of moral rectification? The burden of proof in this case is with the ethical particularist. While the presence of an additional positive motive to that of acting from duty does not badly affect a given state of affairs, the same could not be said about the absence of the motive of duty in the presence of contrary inclinations. The ethical universalist may thus agree that particular affective ties and social inclinations positively complement our duties and increase an agent's pleasure in fulfilling them, but reject the particularist's claim that these inclinations could by themselves determine the worth of a moral action.

This leads to a second objection which questions the legitimacy of institutions and practices brought about to encourage moral virtue and promote acting from duty and in conformity with cosmopolitan principles of justice. On the one hand, educating fellow citizens to adopt similar attitudes, inculcating them with a cosmopolitan sense of the collective and helping them surpass particularist limitations seems necessary in order to overcome the shortcomings of the civil society model of political association. Indeed, a society in which individuals fail to spontaneously do their share and simply comply with the laws out of fear for being punished is likely to face the stability problems discussed above. On the other hand, one might argue that encouraging a universalistic morality and promoting cosmopolitan virtues among imperfect moral agents runs the risk of corrupting their own capacity for good-will. Is it really possible to continue emphasizing the value of autonomy and yet advocate the necessity of moral education to cultivate people's capacities for certain types of decision-making?

The alternative account of political association introduced in the following sections attempts to tackle this objection by emphasizing the political features that keep together the collective body. It articulates a political notion of autonomy which, far from constituting a limit to individuals' capacities to set moral ends acts, as a condition

\footnotetext{
${ }^{83}$ See for a similar response to Stocker's charge of "moral schizophrenia" in the context of a discussion on Kantian ethics Richard Henson, "What Kant Might Have Said: Moral Worth and the Overdetermination of Dutiful Action," The Philosophical Review, no. 88 (1979). and Barbara Herman, "On the Value of Acting from the Motive of Duty," The Philosophical Review 90, no. 3 (1981).
} 
for morality's further development. It focuses on two central features of democratic theory: popular sovereignty and civic education. The former guarantees the legitimate allocation of political obligations and thus makes cosmopolitan agency feasible; the latter motivates citizens to a voluntary concern for cosmopolitan goals and consequently makes the political association stable.

\section{An alternative account of the political community}

The two accounts of the background associative circumstances characterizing the spheres of allocation of cosmopolitan obligations that I have sketched in the previous sections seem to rest normatively on mutually exclusive premises. Each model lacks some essential features found in the other and fails to satisfy the requirements of feasibility and stability that are necessary in order for cosmopolitan obligations to be allocated successfully. So, for example, the civil society model accounts for how to create political institutions but not how to maintain them stable, while the extended family model accounts for how to maintain them but not how to include within their scope the claims of non-members. The former can thus provide feasibility but not stability in the political association; the latter provides stability but with no margins of transformation. In both cases, politics as a specific process in which the role and composition of the collective body is historically and progressively shaped and reshaped appears neglected.

An alternative way of considering the background associative circumstances in which political agency with a cosmopolitan scope can succeed is by starting with a historical analysis of the political community. This account, rather than providing a fixed set of ontological attributes that inhere to the substance of a political community, aims to capture the relevant relational properties that qualify it as a unique social entity in dynamic development. What drives this evolution is politics, broadly understood in terms of a distinctive set of practices and institutions through which individuals recognize each other as joint authors of the same system of rules and are legitimately entitled to put constraints on each other's actions. But it is also politics understood in a more civic sense, as a process in which citizens actively participate in public 
deliberative processes and develop a historical sense of justice that supports the stability of political association.

Being concerned with the historical conditions in which political agency is feasible and the outcome of political action stable, such an account of the political community is non-ideal in all relevant senses. This does not mean that it is also nonnormative. Even a non-ideal account of the political community is, after all, a type of entity, a theoretical approximation rather than a faithful reconstruction able to encompass in a comprehensive list the descriptive features of all existent political communities. So, although a critic may still object that there are existing political practices that do not entirely reflect the relational properties of this non-ideal type, the hope is that my own account is familiar enough to sound plausible and plausible enough to be persuasive.

Forms of collective political organization exist everywhere in the world and their concrete historical development seems to have played a major role in the way abstract principles of social justice have given life to different political, legal and even cultural institutions. The history of modern ideologies with a universal inspiration such as liberalism and socialism cannot be traced without understanding the different, more or less peaceful, application of their principles to specific political and cultural practices, following different patterns of social change. ${ }^{84}$ So, the important point to bear in mind while assessing this alternative account is that I analyse the political community as it is and its practices as they have historically developed through longterm collective processes of economic, social and cultural transformation that help maintain stability in the political association.

Some might consider this development a great fortune, others a regrettable obstacle. I try not to start with an abstract definition of society or with an ideal of human interactions - either atomistic as in the civil society case or holistic as in the family one - but rather consider the way in which political communities and particular institutions have embodied the coexistence, conflict and often maturing of both paradigms throughout history. It is precisely this historical non-arbitrariness of the

\footnotetext{
${ }^{84}$ So, for example, one does not need to know much about the history of socialism to realize that the same principles of social equality and collective responsibility were understood and applied in quite different ways in Yugoslavia, the Soviet Union and China, just like the way in which liberalism is interpreted in the United States might turn out to be quite different from Germany or France.
} 
political sphere, I suggest, that makes its background associative circumstances distinctive and the patterns of interaction among its members unique. And it is precisely because of this distinctiveness and uniqueness that it also emerges as the most relevant context for the allocation of cosmopolitan political obligations.

But what is the "political community"? In one of its most widely accepted definitions, it is described as a collective, historically situated, non-voluntaristic association of people that occupy a defined territory and stand in particular economic, institutional and cultural relations with each other. ${ }^{85}$ As in the civil society model, such relations exemplify a complex system of interdependent needs and interests, which require - in order to be satisfied - collective interactions, including the division of labour among community members and the acknowledgment of certain collective institutions assigning specific duties and responsibilities. As in the large family model, its members recognize each other as both the authoritative source and the subjects of these institutions, consider associative ties to constitute a common source of emancipation and are collectively engaged in developing their human capacities to promote not only the welfare of existing members but also that of future generations.

The fact that members are engaged in mutual practices of constructing collective institutions with a long-term perspective does not always qualify their interactions as "cooperative". The interdependence of needs and interests does not imply that they also constitute a homogeneous whole where each member, by furthering his own good, promotes that of his fellow citizens. Neither does the mutual recognition of a shared public good mean that this is a substantive good shared by everyone at the same time. Specific mechanisms of production or the popular impact of certain ideologies could be such that, in particular historical circumstances, the political community appears profoundly divided and new institutional and legislative measures have to be enacted in order to preserve its unity. But one could assume that the shared history and the distinctiveness of a public political culture are able to support even radical social changes without the interactions of members resulting in irremediable hatred and civil conflict.

${ }^{85}$ See, for example, Max Weber, Economy and Society: An Outline of Interpretive Sociology (Berkeley: University of California Press, [1914] 1978) 901-40. 
So, on the one hand, we do not have to agree on the possibility of harmonizing different needs and interests by simply engaging in cooperative activities; neither do we have to rely too much on the organic unity among members of the same community and no one else. We only have to acknowledge that interdependent needs and interests require reciprocity in various social activities, and that all parties, for various reasons, converge on some principles of coordination and methods of enforcement. Without such convergence, society would be in a condition of perpetual anarchy and violence, and even minimal societal arrangements would be impossible to establish. We also have to acknowledge that, by participating in the political life of the community and being constantly involved in matters of public concern, the members of a community develop a genuine interest for the collective good and a sincere attachment to the collective institutions that they have shaped through their common history. Hence, over time, a political community comes to embody both instrumental mechanisms for accommodating conflicting interests and institutions that members appreciate in their own right, as unique communal bases of emancipation.

The fact that interactions among members are not voluntary does not mean that citizens have no individual identity and no possibility of exit and of being accepted in a new political community, should they wish to migrate. What it means is that exit and entry are not arbitrary; they are neither a priori denied or a priori accepted but rather organized in a way that is compatible with and accountable to the collective political body. This requires that issues regarding the administration of emigration and/or the treatment of newcomers be considered political ones, subject to public deliberative (and potentially agonistic) processes in which members are ready to acknowledge the existence of a plurality of intuitions on the institutional interpretation of certain moral claims. Thus, membership being a non-arbitrary feature does not exclude the possibility of its constant re-negotiation, provided that the reasons for such re-negotiation can be rationally justified to all citizens in light of a specific political culture or a reinterpretation thereof.

So unlike the civil society model, specific political principles may not be adopted simply because they constitute the outcome of a rational agreement of all relevant subjects. This is because although members may agree on the moral desirability of a certain goal, they may disagree on the role specific institutions should 
be assigned in order to realize it; or they may have differing motivations to comply with what those institutional arrangements prescribe. This division does not arise for trivial reasons, it may reflect profound convictions rooted in various comprehensive doctrines that should necessarily emerge and be confronted. Unlike the civil-society model, my own account of the political community does not assume a clear distinction between the public and the private sphere. It is only in the political processes of public deliberation, negotiation, bargaining and eventually protest that this confrontation takes place and the different members of the political community create alliances, make coalitions and try to influence each others' actions.

I emphasize "eventually" because these conflicts of interpretation can be more or less severe and more or less latent according to the different historical stage in which a political community finds itself. There is no need to suppose that cooperation always prevails on insurrection and one can only reasonably assume that an established system of legal rules, a consolidated political tradition and the existence of a public culture will play an important role overtime in facilitating the transformation of power-relations. But it is only in light of the political development of collective social practices that members may publicly confront their comprehensive views on the role that institutions should play to realize specific ends.

This is where my alternative account of the political community is closer to the family model. It relies on the general principles of moral psychology to explain how people prefer complex to more simple forms of goal fulfilment and develop associative loyalties which need not always be based on the satisfaction of personal preferences but rather on a development of particularist attachments. ${ }^{86}$ It emphasizes how, over time, individuals internalize social norms and cooperate on a more stable basis. In this way, relations of friendship, mutual trust or solidarity are created and feelings of guilt or shame tend to emerge when members of a joined associative scheme fail to do their

\footnotetext{
${ }^{86}$ This discussion draws on John Rawls's analysis of the general principles of moral psychology and the development of associative loyalties, see Rawls, A Theory of Justice 409-14, 56-64. Admittedly, Rawls does not use the vocabulary of patriotism to discuss the morality of the association. However, it would be difficult to deny that such a process of moral learning is not linked to the development of particularist loyalties. As Eamonn Callan notices, "the only alternative interpretation is to suppose that in the morality of association individuals become attached to just schemes of cooperation in general and to all who might conceivably participate in them. But that is as absurd as supposing that within the morality of authority children become attached to loving parents in general, as opposed to the particular ones who love them". See Eamonn Callan, Creating Citizens: Political Education and Liberal Democracy (Oxford: Oxford University Press, 1997) 93.
} 
part. As generations replace one another, a shared system of meanings and consolidated ways of knowing and behaving constitute sources of collective flourishing and taking part in those particular activities becomes a form of reciprocal fulfilment. Members come to realize that only partaking in a political associative scheme educates their defective inclinations, moderates their passions, tempers their interests, and fully develops their moral powers. Members tend to protect their common language or languages, consider unique their shared cultural practices, take pride in past scientific and artistic achievements, criticize moral and political failures and perceive collective institutions as a symbol of joint historical progress in social emancipation. These elements contribute to the maintenance of a stable social system of cooperation and ground what is often referred to as the public sense of justice. But clearly, however strong the existence of a public sense of justice, as well as its foundation on shared cultural understandings, does not guarantee that interactions among members will always be peaceful or easy to maintain stable. What this peculiar form of social cooperation does provide is a basis for mutual agreement and the reference to a common good that, although political and not moral, members consider worthy of preservation.

\section{$\underline{\text { 5. Popular sovereignty and civic education }}$}

In conceptualizing how political and institutional development occurs in similar associative circumstances, democratic theorists have traditionally drawn attention to two important features of modern societies: popular sovereignty and civic education. Popular sovereignty provides an account of the criteria that a political decision must meet in order to be considered legitimate. It explains under what conditions citizens are entitled to place coercive constraints on each other's actions and distribute political obligations. According to this view, the only political decisions that citizens may be coerced to comply with are those that they have freely and collectively consented to.

"Freely consented to" may be subject to two interpretations. First, one may understand that what a collective "freely consents to" is the content of specific decisions. A decision is then freely consented to by members of the collective when it is unanimously endorsed, i.e. every single member of the collective agrees with the 
content of every single decision. But there might be difficulties in securing this type of agreement: the size of the collective, the number of options on the table and the disparity of views are likely to render it a remote prospect. A second-best interpretation of "freely consented to" might therefore be developed in response. In the context of a plurality of reasonable but possibly incompatible options what a collective "freely consents to" is a procedure for selecting decisions. Here "freely consents to" implies that if you freely agree with the procedure of selection of a certain decision, then you also commit yourself to endorse its outcome whatever this might turn out to be. In this case unanimity is only required once, namely in establishing the procedure of decisionselection; it is not required for any subsequent, specific decisions. ${ }^{87}$

Following this second interpretation, popular sovereignty lays out the external conditions for a meaningful exercise of one's moral capacities within a plurality of modes of cooperation. ${ }^{88}$ In the absence of freely agreed upon procedures of decisionselection and the collective recognition of what Rousseau and Kant called "the general will", there would be no possible mechanism of coordinating a multiplicity of ends and means. Popular sovereignty expresses politically the notion of moral autonomy. To be morally autonomous means to obey the moral laws that you have given to yourself. To be politically autonomous means to obey the political laws that you have contributed to establishing as a member of the collective. Political autonomy constitutes the external condition of possibility under which moral autonomy can develop. Popular sovereignty grounds political autonomy by establishing that the authors of laws ought also to be subject to them and contains the criterion by which political obligations can be legitimately endorsed. Yet, whilst contributing to making those political obligations feasible, popular sovereignty does not guarantee, by itself, that people will also maintain stable terms of cooperation. Once a decision is adopted following a method to which people have freely consented, what is to stop them furthering their own interests by some other means?

This is where the second feature of democratic theory - civic education acquires a primary role. Civic education is the process by which citizens are taught the virtues of political participation, the centrality of engaging in public discussion, the

\footnotetext{
${ }^{87}$ Hence Rousseau's emphasis that "il n'y a qu'une seule loi qui par sa nature exige un consentement unanime "; see Rousseau, "Of the Social Contract," ch. 2.

${ }^{88}$ See Kant, "The Metaphysics of Morals," 409.
} 
need to show mutual understanding, and the relevance of community life. If citizens' comprehensive doctrines must be confronted every time a political decision comes to the fore, then their critical capacities need to be cultivated, their sensitivity to the nuances of different political positions ought to be sharpened and the discursive resources ensuring their meaningful participation in deliberative processes must be provided. ${ }^{89}$

Civic education consists in the collective activity of distributing the abilities required for an effective exercise of popular sovereignty. Typically, it takes place in public schools, but schools need not be the only public spaces in which civic education occurs. Civil associations, the media and the workplace, for instance, might be just as plausible candidates for civic education. Schools, however, seem to have a primary role. This is not simply because of the compulsory nature of the service they offer or because of the educative function they are institutionally designed to perform. Schools, together with families, are arguably the most important associative environments for the development of one's character. Schools familiarize children with the notion of authority, help them improve social skills, cultivate specific civic virtues and introduce children to past and present aspects of communal life, strengthening social bonds and creating an ethos of solidarity. ${ }^{90}$

This process is particularist at the start. It would be absurd to try and implant on children a universal sense of justice by lecturing them on individual dignity or the concept of freedom and the categorical imperative, or by training them to calculate moral harms and benefits. One usually starts with concrete examples, familiar episodes and stories of emotional identification with those who speak the same language or share similar traditions. Then progressively one builds towards more abstract narratives,

\footnotetext{
${ }^{89}$ There is an ongoing debate between scholars on whether the role of civic education is merely to train citizens to engage with public institutions regardless of their basic moral principles (the legitimacy-based view of education) or whether it must also provide them with critical knowledge, values and the ability to evaluate competing points of view in a way that is conducive to a specific perspective on justice (the autonomy-promoting view of education). What I say on civic education follows the latter position. However, I do not have space here to engage with a detailed critique of the former. For a defence of the legitimacy-based view of education see Harry Brighouse, "Civic Education and Liberal Legitimacy," Ethics 108 (1998). For a defence of the autonomy-promoting view of education see Amy Gutmann, Democratic Education (Princeton: Princeton University Press, 1987). and Eamonn Callan, "Liberal Legitimacy, Justice, and Civic Education,” Ethics, no. 111 (2000).

${ }^{90}$ For an excellent analysis of the role of schools in civic education and a more elaborate discussion of the controversies surrounding them in multicultural democracies see Harry Brighouse, On Education (London: Routledge, 2006).and Callan, Creating Citizens: Political Education and Liberal Democracy 46-62.
} 
refining children's critical capacities. Educational curricula fulfil precisely this role: they expose future citizens to a pool of knowledge on their communal history, literature, cultural practices and political institutions, and thus establish a basis for meaningful social communication. It is often said that this process is likely to be effective only if it espouses a type of patriotism that emphasizes glorious achievements in the interactions among community members and marginalizes episodes of oppression, exclusion or intolerance towards others. ${ }^{91}$ But this need not be the case. Indeed, if civic education promoted patriotic dogmas rather than self-critical historical reflection it would only encourage social hypocrisy and create citizens unwilling to engage with the reasons of others. This would hardly contribute to a stable allocation of political obligations. ${ }^{92}$

\section{Cosmopolitan agency}

Having examined the extent to which conflict and a basis for mutual agreement are present in most political communities, we may characterize the practices of interaction in them as synagonist. ${ }^{93}$ Synagonism emphasizes the conflicting-cooperative character of the relationships existing among members of a political community. Citizens struggle (agon) together (syn) to realize political projects benefiting the entire collective body - being divided in the specific, historical understandings of how collective institutions ought to assign responsibilities, but united in the recognition of their noninstrumental value and in the necessity of preserving their autonomy. In the absence of a shared understanding of the collective end of historical institutions that citizens have

91 See William Galston, Liberal Purposes: Goods, Virtues, and Diversity in the Liberal State (Cambridge: Cambridge University Press, 1991) 244.

92 For a futher discussion of this issue see Kymlicka, Politics in the Vernacular - Nationalism, Multiculturalism, and Citizenship 303-20.

${ }^{93}$ Here I take the term and its etymological interpretation from Nathalie Karagiannis and Peter Wagner who use it to characterize both the type of interactions among members of a political community and a theory of their conceptualization. See Nathalie Karagiannis and Peter Wagner, "Towards a Theory of Synagonism," The Journal of Political Philosophy 13, no. 3 (2005). Their account shares many features with the historical description of the political community I have developed in the previous pages, not the least the fact that the theory of synagonism tries to combine descriptive and normative elements in emphasizing the importance of the political for amending interactions among members. However, as the authors acknowledge, their theory does not cover issues of inter-polity relations. By emphasizing the political features of the sphere of allocation of cosmopolitan duties, this chapter integrates that debate with a discussion of the ways in which obligations to those with whom one does not stand in direct political relations can be understood. This is important modify the impact of globalization processes that separate the locus of a certain decision from the site in which it has an effect. 
progressively created, political alternatives cannot be evaluated and no shifts in courses of action ever occur. However, this very collective end is also subject to continuous revision and expansion in light of emerging political projects and ideals of social transformation.

Cosmopolitanism is itself an emerging political project, questioning the moral standing of states when they fail to cope with the fact that millions of people live in conditions of severe material deprivation and with the realities of global inequalities. However, whether states are more or less able to cope with the negative externalities of, say, a global free-market economy or with the existence of huge power inequalities among them, is not a natural fact, it is a question of political will. Political will requires allocating political obligations. And for political obligations to be allocated, political agency has to be both feasible and stable.

Political communities then play an important, perhaps the most important, role in allocating cosmopolitan obligations. This is not because each exhibits an exclusive understanding of a substantive collective good, impossible as such to be shared with strangers, much less negotiated. Instead, political communities constitute spheres of interaction and dependence in which the problems of living in common can be institutionally addressed, in which members recognize each other as mutually responsible for the outcomes of their collective enterprises, and in which conflicting claims may enter the public arena with a clear reference to what values are called into question. Background historical institutions and a public sense of justice are in this case important not for some kind of intrinsic capacity to accommodate all possible controversies, but for offering the associative frame within which citizens recognize each other's well-being as a condition of their own development, thus influencing their motivation to comply and strengthening their concern for the wealth of the collective body. Far from excluding the possibility that states evolve, enlarge or even fundamentally transform their character (including in a cosmopolitan sense), it is important to emphasize that such changes would still have to occur from within a set of common practices referring to historical institutions, legal texts and a public political culture that members regard as meaningful and worthy of preservation. ${ }^{94}$

94 This account might be thought to resemble Michael Walzer, Interpretation and Social Criticism (Cambridge, Mass.: Harvard University Press, 1987) 21-23. Whilst sharing Walzer's view that social 
We are now in a position to link more straightforwardly the requirements of feasibility and stability for cosmopolitan political agency, to the features of political communities emphasized above, namely, popular sovereignty and civic education. Popular sovereignty is a condition of possibility for the institutional realization of cosmopolitan obligations. It allows enforcing a specific interpretation of the role of political institutions that has gained the consent of the collective body. Civic education guarantees, in the long run, the possibility that everyone, even those particular agents that initially oppose or find it difficult to comply with cosmopolitan-oriented laws as a matter of external coercion, progressively learn to live with them because they reflect the transformation of collective institutions that members consider valuable.

Let us examine both features more in depth. If we agree, as cosmopolitans do, that pluralism with respect to substantive conceptions of the good is an irreducible feature of modern societies, we would have a hard time trying to have all citizens endorse the same view on the role of political institutions roughly in the same time. Take cosmopolitan political obligations to reduce power inequalities. Typically, they will require a transformation of domestic institutions and systems of production and distribution that are coercively imposed on all members of the political association in a way that also benefits non-members. Although agreeing with the broader moral concern, a libertarian will perhaps object that the distribution of material resources to needy populations should be a private matter, a nationalist will argue that levelling down on military power will undermine collective security and so on.

The point of the institution of popular sovereignty is, however, that the authority of political communities is due to legal and political arrangements reflecting the consent - although perhaps not unanimous agreement - of all subjects to political decisions that may not correspond to everyone's interpretation in a particular historical stage. Political membership is not an arbitrary feature. Recognition of the basic principles that regulate common life authorizes fellow-citizens to put constraints on each other's actions following decisions collectively consented to. Thus, reluctant

criticism is much more efficacious when it engages seriously with particular social practices, I do not agree with his scepticism on the very possibility of grounding such criticism on an impartial, universalist account of morality. As I have tried to show in the previous pages, starting the process of moral learning with well-consolidated intuitions and views embedded in particular traditions does not necessarily preclude questioning them from a moral perspective that is ultimately universal in its reach. For a more elaborate critique to Walzer's account along similar lines, see Brian Barry, "Social Criticism and Political Philosophy," Philosophy and Public Affairs 19, no. 4 (1990): 368 ff. 
citizens may object to certain principles or refuse to participate in their making (for example by not voting), but they cannot avoid complying with them once they have been collectively enforced.

One might of course object here that, even if members value non-instrumentally their membership to a political community, they will not necessarily also endorse whatever decision happens to emerge from its internal political processes. On the contrary, precisely because, say, libertarians or nationalists might care for the well being of fellow-citizens, they are more likely to engage in actions of civil disobedience trying to resist what they consider as objectionable policies. But notice that acts of civil disobedience are usually justified when the state ceases to be representative of all its citizens, when there are no further grounds for believing that it reflects norms of fairness in its distribution of social roles and when popular sovereignty is thought to have failed at guaranteeing legitimate conditions for public deliberation. The kind of injustices that justify civil disobedience are usually deep-going, severe and determined by the exclusion of particular political or ethnic groups from the public sphere or by profound violations of human rights within or outside the state's borders. ${ }^{95}$ This would not seem to be the case with cosmopolitan oriented goals. Reasonable people would not consider the principle of equal distribution following from the global scope of sufficientarian justice as an insult to human dignity. The problem, as pointed out by critics, is one of motivating people to discharge cosmopolitan obligations, or indeed even to recognize them as obligations that domestic institutions ought impose. Such motivational weakness might have different sources: people might think that it is not their job to take initiatives to support other states, they might prefer to devote their energies to family and friends, or they might judge it a useless activity unless everyone did the same everywhere in the world. These are precisely the concerns to which the emphasis on the legitimate exercise of popular sovereignty attempts to address.

Popular sovereignty allows the legitimate enforcement of certain principles, thus making cosmopolitan political obligations feasible. But popular sovereignty only explains how it is possible to reach and exercise power legitimately, not how power is maintained and equalized. If citizens do not progressively identify with the laws, if

\footnotetext{
${ }^{95}$ For a discussion of the conditions of legitimacy of civil disobedience see Rawls, A Theory of Justice 319-46.and Michael Walzer, Obligations: Essays on Disobedience, War, and Citizenship (Cambridge MA: Harvard University Press, 1970) 3-76.
} 
cosmopolitanism as a political project fails to foster cross-border solidarity and get a motivational grip on people, besides requiring them to comply, it is not likely to have a very long life. Political agency needs civic education in order to be effective, but civic education does not develop in a vacuum. Neither can it be implemented purely legislatively. This would mean recreating the problem it is trying to resolve. Political obligations are likely to be effective only if they are preceded, and followed, by an attempt to establish cultural as well as a political hegemony. However, this attempt to hegemonize the public sphere is necessarily linked to a historical sense of the collective, to the self-understanding of citizens as members of a community of fate, to justified ways of reasoning and debating, to a national literature, to dominant religious books, legal traditions and historical institutions. Far from ignoring comprehensive doctrines as a private issue that should be kept separate from the public sphere, civic education requires appealing to them every time a political project needs to be assessed, if this very project also hopes to be continuously endorsed.

Various authors have explored ways of realizing a cosmopolitan civic education within particular political communities. We need not go into the details of their proposals here. ${ }^{96}$ It is enough to mention some of the institutions through which cosmopolitan civic education processes could take place: the role of schools in offering educational curricula where a plurality of cultural and political perspectives emerge and are confronted, the role of the media in documenting pressing economic and social questions even outside one country's borders, and the role of local civil and political movements in directing their efforts to issues of global social justice. One might object that a similar cosmopolitan civic education distracts attention from community life and would "rob" people from their "concreteness" and "immediacy". 97 This need not be the case, especially if we consider that even within particular political communities national culture, traditions and patriotic allegiances are not the symbol of an eternally harmonious life in common, but of the politically mediated effort to create unity out of a variety of different, often incompatible, perspectives. The exposure of modern

\footnotetext{
${ }^{96}$ For a good overview on the controversies surrounding this issue see Kevin McDonough, and Walter Feinberg, Citizenship and Education in Liberal-Democratic Societies - Teaching for Cosmopolitan Values and Collective Identities (Oxford: Oxford University Press, 2003). For an excellent defence of cosmopolitan civic education see Martha C. Nussbaum, Cultivating Humanity: A Classical Defense of Reform in Liberal Education (Cambridge: Harvard University Press, 1997).

97 See Benjamin Barber's essay on "Constitutional faith" in Nussbaum, ed., For Love of One Country? 36.
} 
societies to the possibility of cross-cultural tensions, especially with regards to the integration of migrants, might motivate initiatives for a more cosmopolitan civic education, preparing citizens to reflect upon relations between countries and cultures from a critical global perspective. But if this is so, why not try "any" political route to cosmopolitanism? Why insist on statist agency?

Machiavelli wrote "he who desires or wants to reform the State of a City, and wishes that it may be accepted and capable of maintaining itself to everyone's satisfaction should at least retain the shadow of ancient forms". For he added, often "the general mass of men are satisfied with appearances, as if it exists, and many times are moved by the things which appear to be rather than by the things that are. This ought to be observed by all those who want to abolish an ancient (system of) living in a City and bring it to a new and more liberal one." And, "as new things disturb the minds of men, you ought to endeavour that these changes retain as much as possible of the ancient (forms) ... only he who wants to establish an absolute power, which by authors is called a Tyranny, ought to change everything."

Cosmopolitan political agency can succeed only by taking into account the background associative circumstances of particular political communities. Cosmopolitanism becomes a feasible option by taking advantage of the legislative and political mechanisms that allow citizens to transform collective institutions through constraining each other's actions. It may hope to be stably maintained only by appealing to familiar institutions, deeper social ties, cultural resources and mutual understandings that motivate imperfect moral agents. Moral imperatives would in this case not appear over-demanding and citizens would not comply simply out of fear from coercive mechanisms but out of a sincere attachment with political institutions that they have contributed to develop.

Now, this analysis of political obligations from the internal perspective of particular political communities leaves entirely out of its scope the further question of how the principles regulating interactions among political communities in the international sphere should be conceived. Cosmopolitanism is ultimately a theory concerning the transcendence of particular political boundaries. Even though it should rely on existing background associative circumstances to realize political obligations, it

\footnotetext{
${ }^{98}$ See Niccolo Machiavelli, Discourses on Livy (Chicago: Chicago University Press, [1517] 1996) 60.
} 
cannot be content until social justice has been globally realized. But how can cosmopolitan political obligations be enforced in the first place? If it is right to say that ordinary people are more likely to take seriously particularistic commitments than duties to fellow human beings, why hope that there will be enough of them interested in issues of global justice and equal empowerment to lead cosmopolitan political campaigns? If certain political processes are successful in one particular sphere, what guarantees that the same will occur in another one?

The following chapter explores some of these issues in further detail. However, it might be worth spending a few words on one general objection looming above all of them. The objection runs as follows. Either it is reasonable to assume that ordinary moral agents can be motivated by cosmopolitan obligations or it is not. If the answer is yes, the particularist route to cosmopolitanism seems unnecessary since the standard cosmopolitan accounts (i.e. political universalism) suffice for the stable allocation of cosmopolitan political obligations. If the answer is no, then the particularist route appears irrelevant since it ends up being as utopian on the feasibility of cosmopolitan obligations as the alternatives it tries to challenge.

This objection would be a plausible one if politics were a matter of "either or." In most cases, historically at least, the allocation of political obligations seems to have been a question of how much, when, where and how. Several political projects may have ringed utopian in a certain place at a particular time, and yet prove perfectly feasible in different associative circumstances at a later point; that is, they may have been received with hostility in an initial phase only to become a collective identity marker in a successive one. Two hundred years after a progressive philosopher's invective against human rights even the most repressive government would be embarrassed to publicly declare those rights "nonsense upon stilts." 99 So we might think about cosmopolitan principles now. They motivate some agents, some they leave indifferent and others might object to them. The important issue to focus on is: in what associative circumstances cosmopolitan political agency is most likely to prove successful?

\footnotetext{
${ }^{99}$ See Bentham 's discussion of human rights in Jeremy Waldron, ed., Nonsense Upon Stilts': Bentham, Burke, and Marx on the Rights of Man (London: Methuen, 1987).
} 
The previous pages have tried to answer this question by emphasizing two important features of particular political communities or states as we know them: popular sovereignty and civic education. Popular sovereignty clarified how cosmopolitan agency might become a feasible option. Civic education clarified how cosmopolitan projects within the polity could be stably promoted. In many countries there seem to be enough egalitarian political actors motivated to transform their own states, but there are probably not enough capable of doing it on a global scale. Within particular political communities, once certain cosmopolitan goals are brought into particular public spheres, they can be made reciprocally acceptable to members by employing legitimate mechanisms of institutional transformation. And once the enforcement of political duties is achieved, newly shaped institutions operating within a shared public culture may develop practices of voluntary constraint among members. Here the statist route to cosmopolitanism seems far from superfluous.

\section{Conclusion}

This chapter tried to develop an account of the associative conditions under which cosmopolitan agency would obtain feasibility and stability. It tried to suggest that the kind of obligations flowing from cosmopolitan principles, should be allocated politically and not just morally. When enforcing political obligations, citizens can legitimately constrain the activities of fellow-members and act collectively to reform particular political institutions so as to align them with cosmopolitan goals. Where this kind of political action has been successful, a polity can continuously support cosmopolitanism and maintain stable a political association by relying on historical and cultural practices developed among community members. There is no guarantee that political agents will succeed in enforcing demanding cosmopolitan principles of the kind discussed in the previous chapter. But it is possible to think of a model according to which a similar transformation might occur. Illustrating this model is the task of the following chapter. 


\section{Chapter VI}

\section{Statist Cosmopolitanism:}

\section{From Principles to Agency}

\section{Politics as art: the idea of a cosmopolitan avant-garde}

The previous chapter defended a non-ideal account of the background associative conditions under which the political realization of cosmopolitan goals could be considered a feasible and a stable option. It tried to show, on the one hand, how political obligations with a cosmopolitan scope may be realistically allocated where the members of a specific associative scheme are able to use legitimate decision-making mechanisms to constrain reciprocal public interactions. On the other hand, it emphasized that where political institutions have historically acquired the collective support of the citizen body, institutional schemes leading to the fulfilment of cosmopolitan obligations are more likely to be stably maintained throughout time.

The present chapter builds on the centrality of political communities for the scope of global justice. It enquires into the question of what specific agents could most efficiently undertake cosmopolitan political transformations. As we have seen in the previous chapters, one of the most common criticisms against existent cosmopolitan proposals in favour of global equality emphasizes their weak motivational force and the over-demanding nature of their claims in the absence of a global ethos of solidarity. The strength of conceiving the allocation of cosmopolitan obligations as a political and not just moral issue is that such analysis does not need to make heroic assumptions about what ordinary citizens will or will not be motivated to do when it comes to specific initiatives promoting cosmopolitan justice. It is enough to rely on those 
individuals, civil movements and political forces which are already morally or socially sensitive to issues of poverty and oppression and argue that these may be assigned responsibility for leading political actions transforming the state in a cosmopolitan direction.

This chapter attempts to clarify this issue by introducing the notion of a "cosmopolitan avant-garde" in order to refer to those individuals, civil associations and political agents responsible for promoting global justice initiatives within particular states. It starts by exploring how one should understand the concept of "avant-garde" movement, its relevance in art and the analogies between avant-garde movements in art and politics in using available resources in tradition in order to promote emancipatory visions of society. It then discusses who might constitute an avant-garde "cosmopolitan" movement and how its civic and political action might affect the rest of the citizen body thus gaining support for cosmopolitan transformations. I try to emphasize the role of grass-root organizations and trans-national advocacy networks in educating local publics to cross-border solidarity and from there proceed to show their potential influence on the rules of interaction in the international sphere. The implicit assumption is that political transformations, including those cosmopolitically inspired, do not occur in a vacuum but are influenced by specific economic, social and political factors and develop within the background of a public culture and historical events shaping the way in which citizens mobilize. Below I argue that the attempt to realize global justice should be considered in continuity with the democratic struggle for the progressive expansion of political accountability in the public sphere. A cosmopolitan avant-garde would transform society in ways similar to those of artistic and political innovators in critical historical stages - taking the lead in developing an emancipatory social project, which contrasts the unequal distribution of power in the global sphere.

\section{The concept and its development: artistic avant-gardes}

The notion of an "avant-garde" movement is of course not new. According to the Oxford English Dictionary, the term originally appeared in the $15^{\text {th }}$ century to denote 
"the foremost part of an army advancing into battle (also called the vanguard)". ${ }^{1}$ Later on it has been used both in art and in politics to emphasize the leading role of particular individuals and social forces in transforming existing cultural and political practices in light of new projects for the emancipation of society. Apparently the first use of the term in this second sense is owed to Claude Henri de Saint Simon's Literary, Philosophical and Industrial Opinions, published for the first time in 1825. In this last work Saint Simon emphasizes the power of art in using imagination to appeal to people's feelings in order to facilitate society's transition toward a more progressive and civilized age. In the course of a dialogue between the scientist and the artist on the role of each for the project of human emancipation, he has the latter declare in a somewhat superior tone:

Let us unite. We, the artists, will serve as the avant-garde: for amongst all the arms at our disposal, the power of the Arts is the swiftest and most expeditious. When we wish to spread new ideas amongst men, we use in turn the lyre, ode or song, story or novel; we inscribe those ideas on marble or canvas[...] We aim for the heart and imagination, and hence our effect is the most vivid and the most decisive. ${ }^{2}$

And further:

What a most beautiful destiny for the arts, that of exercising over society a positive power, a true priestly function, and of marching forcefully in the van of all the intellectual faculties, in the epoch of their greatest development! ${ }^{3}$

By reserving to the artists a crucial role in promoting human emancipation, Saint Simon intended to confer a more straightforward political meaning to the Enlightenment ideal of art as a means for conveying socially useful projects. Already in the French Encyclopédie (1751) of Diderot and D'Alembert the entry on "Beaux Arts" (believed to have been written by Diderot himself) exhorted the men of Academia to visit the ateliers (qu'il descende dans les ateliers), and produce works that determined

\footnotetext{
1 "avant-garde" A Dictionary of Twentieth-Century Art. Ian Chilvers. Oxford University Press, 1998. Oxford Reference Online. Oxford University Press. European University Institute Library. 16 May 2007 http://0www.oxfordreference.com.bibliosun.iue.it:80/views/ENTRY.html?subview=Main\&entry=t 5.e187. Accessed $17^{\text {th }}$ May 2007.

${ }^{2}$ Henri de Saint Simon, Selected Writings on Science, Industry and Social Organization, trans. Keith Taylor (London: Croom Helm, [1825] 1975) 281.

${ }^{3}$ Ibid.
} 
"the artists to read, the philosophers to think usefully and the powerful to make a useful (utile) exercise of their authority and recompenses" - a call that would have been literally taken up later by the avant-garde movement of the Bauhaus. ${ }^{4}$ Saint Simon's idea of artist-leaders placed the latter at the centre of a trial administrative elite composed of scientists and industrialists/artisans and assigned them a crucial role in communicating to the masses through didactic means whatever science achieved through solid demonstrations.

It comes at no surprise then that in the earliest stages of their development, artistic avant-gardes were characterized by their political commitment to social justice and by the attempt to use aesthetic means to influence a particular mass culture. ${ }^{5}$ Inspired by the ideas of Saint Simon, Proudhon, Fourier and later Marx - as well as deeply influenced by the events leading to the Paris Commune - avant-garde painters, writers and musicians perceived their role in society as a break with conventional aesthetic canons and made revolutionary use of artistic techniques to raise public awareness on burning social issues. The most interesting feature that the movement exhibited was that in most cases, theory and artistic product coincided. The aim was appealing to familiar expressive means but in a way that conveyed a radically different message on the role of art and its relation to mass culture. As one critic has put it, the avant-garde could only make sense "if it remained dialectically related to that for which it serves as the vanguard - speaking narrowly to the older modes of artistic expression,

\footnotetext{
4 “Qu'il sorte du sein des Académies quelqu'Homme qui descende dans les ateliers, qui y recueille les phénomènes des Arts, \& qui nous les expose dans un ouvrage qui détermine les Artistes à lire, les Philosophes à penser utilement, \& les Grands à faire enfin un usage utile de leur autorité \& de leurs récompenses", see Denis Diderot and Jean Le Rond D'Alembert, Encyclopédie, Ou Dictionnaire Raisonné Des Sciences, Des Arts Et Des Métiers, 28 vols. (Geneve; Paris; Neufchatel: Briasson and others, [1754-1772]) 713.

${ }^{5} \mathrm{My}$ analysis of artistic avant-gardes is quite selective and has a merely illustrative function. I focus only on some significant representatives of the so-called "historical avant-gardes", a term used to denote those movements operating between the end of the $19^{\text {th }}$ century and the beginning of the $20^{\text {th }}$ century. I do not consider the neo-avant-gardes of the late twentieth century (for example Pop Art, Coneptual Art, Fluxus etc.). This is not only because the aesthetic nature and artistic intentions of neo-avant-gardes are very different from those of historical ones but also because their production is explicitly politically disengaged. Where the historical avant-gardes tried to reinterpret the role of art in light of important changes in society (starting from the events of the 1848 Paris commune), neo-avant-gardes merely repeated the strategies of their predecessors but abandoned social struggle. For one pioneering analysis of this issue see Peter Buerger, Theory of the Avant-Garde (Manchester: Manchester University Press, 1984). For an interesting discussion of the death of avant-gardes in the $20^{\text {th }}$ century and the relationship between art and politics see Eric Hobsbawm, Behind the Times: The Decline and Fall of the TwentiethCentury Avant-Gardes (New York: Thames and Hudson, 1999).
} 
speaking broadly to the life of the masses which Saint Simon's avant-garde scientists, engineers and artists were to lead". 6

Gustave Courbet, arguably one of the pioneers of the historical avant-garde movement and a committed social activist, explicitly adopted this point of view in works judged by critics as "a pursuit of ugliness" because of their rebellious realism and poignant representation of the workers' conditions in industrial societies. When his now famous painting "Burial at Ornans" (1849) was rejected by an official international jury in Paris because of its "brutal" realism in representing manual labourers as heroic characters, Courbet reacted by opening his own exhibition space called "Le Réalisme". The event was relevant not simply because it created a precedent for the representation of works refused by official exhibitions, a habit that was to become later one of the identifying features of historical avant-gardes. ${ }^{7}$ Courbet conceived his work above all as a means to increase the public's awareness about social conditions in industrial societies, as well as a protest toward the allegedly "idealistic" and "elitist" canons of official aesthetics. "An object abstract, invisible, nonexistent", he claimed, "is not in the domain of painting". 8

It would be difficult to explain the origin and development of historical avantgardes in art without considering how their aesthetic innovations were shaped by, and aimed to account for, the profound political transformations in which their protagonists took active part. The originality and interest of early avant-garde works lies precisely in their attempt to combine art criticism and social engagement in a way that both speaks to tradition and progressively abandons it by pointing at new routes of development. In the second generation of the movement, for example, this issue was explicitly theorized by impressionists with socialist and anarchist sympathies such as Camille Pissarro, Paul Signac and later Pablo Picasso and affected not just the content of their works but also

\footnotetext{
${ }^{6}$ Andreas Huyssen, After the Great Divide : Modernism, Mass Culture, Postmodernism (Bloomington: Indiana University Press, 1986) 5-6.

7 This is but one of the elements distinguishing historical avant-gardes from those neo-avant-gardes whose integration in the media and desire for official recognition has contributed to undermine their artistic credibility. Andy Warhol was arguably the first to operate the transition from the historical to the new conception, actively seeking media representation and involvement in the official art industry. For a further discussion of this issue see Sven Lütticken, "Secrecy and Publicity. Reactivating the AvantGarde," New Left Review 17 (2002). and Hobsbawm, Behind the Times : The Decline and Fall of the Twentieth-Century Avant-Gardes.

${ }^{8}$ Cited in Donald D. Egbert, "The Idea Of "Avant-Garde" In Art and Politics," The American Historical Review 78, no. 2 (1967): 341.
} 
their painting techniques. So for example Paul Signac thought that the pointillist style of painting represented the artists testimonial of "the great social process which pits the workers against Capital" and that revolution "will be found much stronger and more eloquent in pure aesthetics... applied to subjects like working-class housing"9.

The call for taking the lead in promoting human emancipation through artistic innovation became most inspiring for several avant-gardes in the decades going roughly from the October Revolution to the affirmation of Nazism in Germany and Stalinism in the Soviet Union. In literature, for example, the Surrealist movement supported by important intellectuals and activists such as André Breton, Louis Aragon, Paul Eluard and Jacques Prévert theorized the "mechanic style of writing" as a means of liberating thought from the commodified conventions of bourgeois society and establishing a new cultural hegemony. Spontaneously recording the dreams, visions and utopias of the artist intended to overcome the illusionary coherence of bourgeois every day life with its rooted habits, stylized expressive means and concealed mechanisms of repression in order to release new ways of exploring experience and sharing future visions of society. "We make no claim to change the mores of mankind", declared the Surrealist manifesto of 1925, "but we intend to show the fragility of thought, and on what shifting foundations [...] we have built our trembling houses". ${ }^{10}$ If this was still too abstract, the movement made its intentions more clear in the early 1930s by changing the name of its official journal from "Révolution surréaliste" to "Le surréalisme au service de la révolution". 11 The time had come for poets, Eluard declared, "to affirm their right and duty to be deeply immersed in the life of other human beings, in ordinary life [...] Real poetry is included in anything that does not conform to ordinary morality, a morality

\footnotetext{
${ }^{9}$ Cited in Charles Harrison and Paul Wood, eds., Art in Theory 1815-1900: An Anthology of Changing Ideas (Oxford: Blackwell, 1998) 797.

${ }^{10}$ Cited in Maurice Nadeau, The History of Surrealism (Cambridge MA: Belknap Press, 1989) 240-41.

${ }^{11}$ The first page of its first issue published a telegram sent to the International Office for Revolutionary Literature in Moscow, where the surrealists declared to submit to the directives of the II International. For an analysis of this issue see Mario De Micheli, Le Avanguardie Artistiche Del Novecento (Milan: Feltrinelli, 1988) 178. The socialist movement was not always at ease with artistic avant-gardes, however. Rosa Luxembourg, for example, had to justify herself for preferring more traditional literature and even Leon Trotsky, usually attentive to new forms of art allegedly disapproved of the extreme subjectivism of avant-gardes. For a discussion of this issue see Eric J. Hobsbawm, "Socialism and the Avantgarde in the Period of the Second International," Le Mouvement Social, no. 111 (1980): 195-8.
} 
that can only preserve the constituted order by building banks, garrisons, prisons and churches". ${ }^{12}$

Participating with enthusiasm in the affirmation of the October revolution, Russian avant-gardes went even further in advocating the relevance of artists as "social engineers" involved in the production of work which had to be both functional and accessible even to the uncultivated public. Ranging from a variety of styles and themes, from Malevich's and Lissitzky's suprematism to Rodchenko's constructivism, the goal of avant-garde movements was hermeneutical, critical and didactic in the same time. It aimed, on the one hand, to put an end to the commonsense understanding of art as an activity that could only interest cultural elites. On the other had, and more didactically, it tried to familiarize the masses with abstract thinking and the use of creative associations. It is for this reason that for example, Lissitzky's experimental art developed into work in typography, exhibition design, and architecture and that Malevich defended his abstract paintings as showing the progressive liberation of people from the domination of work and constituting the true expression of their newly acquired freedom. ${ }^{13}$

The most persuasive avant-garde attempts to introduce innovations in art and society were those who tried to subvert specific traditions from within, while continuing to act as their critical voice. This point becomes particularly clear if we contrast the scarce success among the broader public of Futurist and Dadaist attempts, aiming to destroy centuries of historical accumulation, with the popularity of emergent forms of art such as cinema and later Jazz, which combined traditional ways of enjoying aesthetic products with their extrapolation from the realm of high culture. ${ }^{14}$ More generally, the most interesting and promising avant-garde productions seemed to be those who were perceived by their authors in continuity with the classic works that inspired them. Picasso for example, spent several years analysing and absorbing the style of authors such as El Greco, Rubens, Velasquez and Titian before advancing into new territory. Even then, some of the most brilliant paintings represented variations on

\footnotetext{
${ }^{12}$ Cited in Micheli, Le Avanguardie Artistiche Del Novecento 178. My translation.

${ }^{13}$ See Alan C. Birnholz, "The Russian Avant-Garde and the Russian Tradition," Art Journal 32, no. 2 (1973): 146-9.

${ }^{14}$ It should be pointed out that the first experiments trying to render music accessible to the mass-public had already started in $19^{\text {th }}$ century opera, in the works of Wagner or Mascagni. For more on this issue Eric Hobsbawm, The Age of Empire (London: Weidenfeld and Nicolson, 1987) 220-24.
} 
classical work, as testified by the many reinterpretations of Velazquez's "Las Meninas" or of Courbet's "Demoiselles de la Seine". In a similar way, Brecht's "epic theatre", far from mounting a radical attack to art as an institution, tried to appropriate tradition in order to change its function and cultivate critical distancing in the public. Aristotle's Poetics and its focus on feelings remained a constant reference point for Brecht's articulation of the concept of "estrangement" (Verfremdung), a concept denoting the attitude of a public which did not emotionally identify with the characters of a drama (as in the Aristotelian tradition) but rationally adopted a politically fruitful critical perspective.

The effort to act as "the creative conscience of a usable tradition" constituted the main concern of several avant-garde movements and represented a much more arduous and subtle task than that of rejecting all existing institutions and tastes. ${ }^{15}$ Indeed, as one critic puts it, "tradition already had its official guardians, who, armed with an elaborate system of sanctions, were determined to resist any change that required them to reconsider the precious inheritance in their charge". Instead, "a constant reconsideration and revaluation of the past is precisely what the master artists of the avant-garde were forcing upon the official guardians of taste, and doing so not out of any conscious determination to 'subvert' tradition but, on the contrary, to rescue it from moribund conventions and redefine it in the most vital terms - terms that spoke directly to the sensibility of the age". ${ }^{16}$

Avant-garde art did not initially constitute simply one aesthetic fashion among others - as it occurs all too often in our days - but represented the first major attempt to radically reinterpret the role of artists in society. By challenging the traditional division of labour between history, art, philosophy and politics it tried to construct a more transparent relation between socially engaged artists and the broader public to which their call for a different, more just society was addressed. Whether it was in music, literature, architecture or visual arts, the link that avant-garde movements established between existing cultural practices, innovations in aesthetic canons and political initiative acted both as a critique of present cultural and social institutions and as a concrete instance of their social emancipation. The means through which historical

\footnotetext{
${ }^{15}$ Hilton Kramer, "The Age of the Avant-Garde," Journal of Aesthetic Education 7, no. 2 (1973): 43.

16 Ibid. On the relationship between avant-gardes (including artistic ones) and tradition see also Göran Therborn, "Entangled Modernities," European Journal of Social Theory 6 (2003): 296.
} 
avant-gardes pursued their goals might have been different, and more or less successful, but the attempt to appropriate centuries of artistic legacy, reinterpret it and put it at the service of a larger social project was shared by many.

It was when such fruitful relationship with tradition waned, or was deliberately rejected by its protagonists, that the historical avant-garde became most vulnerable to attack. ${ }^{17}$ It was when references to tradition disappeared from the project altogether (both consciously and unconsciously) that historical avant-gardes died. ${ }^{18}$ As we shall shortly see, similar risks threaten political avant-gardes and similar opportunities present themselves. As Brecht put it "a vanguard can lead the way along a retreat or into an abyss. It can march so far ahead that the main army cannot follow it, because it is lost from sight and so on". ${ }^{19}$ Political avant-gardes, just like artistic avant-gardes, can avoid either leading backwards or losing their way, only if they are able to adequately combine a global vision of society with local commitments, only if they are able to innovate in a way that also communicates with tradition. Cosmopolitanism, by its very nature, is all the more subject to similar risks. It can either be rooted in the state, to start with, or fly so high that one easily loses sight of it.

\section{The analogy between art and politics (I): the public}

Interesting similarities between the spheres of art and politics emerge very clearly if we focus on the analogy of aesthetic and political judgment from both the point of view of the actors involved as well as that of the public. Drawing on Kant's Critique of the power of judgment, we may start to clarify the latter by illustrating how the maxims orienting claims of taste are analogous to those evaluating the importance of political events. ${ }^{20}$ In discussing the status of aesthetic judgment, Kant underlines how even

\footnotetext{
${ }^{17}$ This was the reason for which Georg Lukàcs, for example, always preferred the realism of Balzac and Tolstoj and criticized literary avant-gardes for reflecting bourgeois decadence and for their inability to be politically constructive. Unfortunately I cannot explore more in depth the controversy that this issue generated between defenders of the avant-gardes such as Adorno, Bloch and more ambiguously Brecht, on the one hand, and Lukàsc, on the other. For some of the important exchanges see Perry Anderson, ed., Aesthetics and Politics (London: Verso, 1977).

${ }^{18}$ See Hobsbawm, The Age of Empire 220-32, Hobsbawm, Behind the Times : The Decline and Fall of the Twentieth-Century Avant-Gardes.

${ }^{19}$ Bertolt Brecht, “Against Georg Lukàsc," New Left Review 84 (1974): 41.

${ }^{20}$ The following comments have a great deal in common with Hannah Arendt's interpretation of Kant's Critique of judgment, see Hannah Arendt, Lectures on Kant's Political Philosophy, ed. Ronald Beiner
} 
though the claims of taste are always rooted in a particular experience of the subject and do not rely upon an ideal concept of what counts as beautiful in art, they nevertheless aim to be generally valid. Unlike private sensations and feelings, aesthetic judgments are not merely assertions of subjective preferences but require to be shared by a broader public. And rightly so: for Kant claims of taste are grounded on the presupposition of a kind of communal sense (sensus communis) which brings all discursive participants to abstract from contingent circumstances and private interests and hypothetically take into account the representations of everybody else. Because aesthetic judgments are autonomous, impartial and public, the kind of relation that they aim to establish between the perception of a beautiful product of art or nature and its assessment in a particular claim of taste is thought to be universally extensible. ${ }^{21}$

According to Kant it is possible to illustrate the status of aesthetic judgments and the reasons for which those who perform them expect a general agreement by enlisting three maxims upon which the presupposition of a communal sense is grounded. These are: 1) to think for oneself; 2) to think in the position of everyone else; 3 ) always to think in accord with oneself. ${ }^{22}$ In the first case, every time a product of nature or art is described as beautiful we make use of "unprejudiced" thought since we do not assess the object considering its utility for us or a private interest involved but only its pure aesthetic value. In the second case we recur to "broad-minded" thought because we assume the product of art would produce the same disinterested feeling of pleasure on any other impartial observer. In the third case we deploy "consistent" thought because we coherently combine the first two and formulate a judgment that we believe to be exemplarily valid.

Now it is interesting to notice how the first two maxims that Kant thought could illustrate some of the fundamental features of his critique of taste are reminiscent of the

(Brighton: Harvester, 1982 ). However my emphasis on the analogy between aesthetic and political judgment is grounded on a reading of Kant's three "maxims" of taste and their analogous function in Kant's political philosophy whereas Arendt's remarks are based on the discussion of the status of aesthetic judgments as "exemplarily valid". I believe that focusing on the "maxims" guiding the claims of taste rather than on the formal structure of aesthetic judgment allows emphasizing the analogies between art and politics without neglecting Kant's practical and political philosophy. This is important because it avoids one of the most common objections that Arendt's interpretation of the third Critique has attracted (i.e. underestimating Kant's moral theory).

21 Immanuel Kant, Critique of the Power of Judgment, ed. Paul Guyer (Cambridge: Cambridge University Press, [1786] 2000) 173-6.

22 Ibid, 174. 
principles that ought to guide enlightened citizens in their assessment of political institutions. The first idea, that of autonomous and unprejudiced thought, promotes emancipation from the errors of superstition and the dogmatic acceptance of any given authority, preparing citizens to be active members of a self-legislating collective. This enlightened disposition, which Kant defines as "the emergence of men from their selfincurred minority" ${ }^{, 2}$, together with the imperative of only obeying the laws that one has autonomously prescribed to himself are necessary preconditions for that critical exercise of public reason upon which the idea of political legitimacy rests. ${ }^{24}$ Here Kant insists that although acting within a particular political sphere, citizens should always be able to look beyond it and assess political institutions from a cosmopolitan perspective. As he puts it, the unprejudiced use of public reason constitutes an essential demand for an agent who is both required to obey the laws in his capacity of citizen, but who also "regards himself as a member of a whole commonwealth, even of the society of citizens of the world". ${ }^{25}$

The ability to make use of "enlarged thought" while reflecting on a beautiful product of art, is also the same displayed by the members of an enlightened public in their evaluation of transformative political events. Indeed, the capacity of external observers to participate in a disinterested, yet passionate, manner in the affirmation of the French revolution was perceived by Kant as a sign of moral progress in history. Judging political issues from an enlarged perspective, which requires the spectator to put himself in the place of everybody else, even sacrificing one's own self-interest, reveals an important disposition. As Kant puts it, this disposition constitutes a revolution in the "mode of thinking" whereby the public manifests "universal yet disinterested sympathy" to the deeds of those who are brought to sacrifice their own life

${ }^{23}$ Kant, “An Answer to the Question: What Is Enlightenment," 17.

${ }^{24}$ See also Kant, "On the Common Saying: That May Be Correct in Theory, but Is of No Use in Practice.".

${ }^{25}$ Kant, "An Answer to the Question: What Is Enlightenment," 18. Interestingly, Kant refers to the concept of 'enlightenment' also in the passage of the Critique of judgment in which he clarifies the maxims of the judgment of taste. "Liberation from superstition is called enlightenment, since, although this designation is also applied to liberation from prejudices in general, it is superstition above all (in sensu eminenti) that deserves to be called a prejudice, since the blindness to which superstition leads [...] is what makes most evident the need to be led by others, hence the condition of a passive reason". Kant, Critique of the Power of Judgment 175. 
for the realization of justice. ${ }^{26}$ Just as a person feels elevated and moved by the lyrics of a poem, the music of an opera or the characters of a painting because the "beautiful" is perceived as a "symbol" of the morally good, the general admiration and unselfish enthusiasm with which the public assists at the unfolding of progressive political events constitutes a "sign" of the possibility of moral emancipation. ${ }^{27}$

The analogy between aesthetic and political judgment illustrates the capacity of individuals to act following "enlightened", "enlarged" and "consecutive" maxims. Ordinary citizens are perfectly able to participate in the transformation of their polity even against their selfish individual interests, provided background conditions for political mobilization are available. What is the role of avant-gardes in the making of such conditions? To understand this issue we need to consider another type of similarity between art and politics.

\section{The analogy between art and politics (II): actors}

The first explicit shift in the use of the term "avant-garde" from the sphere of art to that of politics occurred when Lenin in his famous 1902 essay "What is to be done?" referred to the communist party as the "vanguard of the revolutionary forces in our time". ${ }^{28}$ The transformative activity of particular political agents was here perceived in analogy with that of innovative artistic movements, creatively invoking a new vision of the good polity and progressively removing obstacles to the realization of social justice.

The image of politics as a special kind of creative activity; the art of governing the polity goes back at least to Aristotle. Rousseau, in the social contract also emphasizes how "the constitution of a man is the work of nature, that of the State is the work of art". ${ }^{29}$ The interesting addition coming from the notion of "avant-garde"

\footnotetext{
${ }^{26}$ Immanuel Kant, "The Contest of Faculties," in Political Writings, ed. Hans Reiss (Cambridge: Cambridge University Press, [1798] 1991), 182. For further analysis of this issue in Kant see Larry Krassnof, "The Fact of Politics: History and Teleology in Kant," European Journal of Philosophy no. 2 (1994): $32 \mathrm{ff}$.

${ }^{27}$ It is possible to find some interesting thoughts on the beautiful as a symbol of the morally good in Kant, Critique of the Power of Judgment 226-7. This idea of the beautiful as related to the morally good is an aspect of Kant's third Critique that interpreters emphasizing the difference between Kant's conception of the autonomy of art and the reaction of avant-gardes to such an ideal often undermine, see for example Buerger, Theory of the Avant-Garde 42-46.

${ }^{28}$ Vladimir I. Lenin, What Is to Be Done? (New York: International Publishers, [1902] 1929) 85.

${ }^{29}$ Rousseau, "Of the Social Contract," 109.
} 
political agency is its focus on critical circumstances in which existing institutional and discursive resources appear exhausted or insufficient to resolve society's political impasse. The products of avant-garde movements are there to symbolize that the ends of reason do not belong to an abstract realm of the hypothetically possible but may be promoted (and in fact are) in real world circumstances.

In a way similar to artists, avant-garde political agents must use imagination and invest creative energies in giving concrete shape to an abstract vision of the good polity. Both kind of movements aim at transforming society by introducing new discourses which solicit a particular public sphere to become aware of its own limits and opportunities. Both constitute teleological activities whose strategies of mobilization rely on the ability to link the past - what has already been achieved - with a vision of the future - what remains to be done - and of persuading the public that their project is a meaningful one. And in both cases subjective participation plays a crucial role: the whole project may succeed or fail according to the ability of leaders and activists to subordinate tradition to the goals of a superior intellectual and political reform: a reform desperately needed, if not yet fully conceptualized.

This complex relationship between tradition and innovation with regard to avant-garde political agency is illuminatingly introduced by Antonio Gramsci's with a metaphor emphasizing the analogies between art and politics. As Gramsci puts it:

The active politician is a creator, an initiator; but he neither creates from nothing nor does he move in the turbid void of his own desires and dreams. He bases himself on effective reality, but what is this effective reality? Is it something static and immobile, or is it not rather a relation of forces in continuous motion and shift of equilibrium? If one applies one's will to the creation of a new equilibrium among the forces which really exist and are operative - basing oneself on the particular force which one believes to be progressive and strengthening it to help it to victory — one still moves on the terrain of effective reality, but does so in order to dominate and transcend it (or to contribute to this). What "ought to be" is therefore concrete; indeed it is the only realistic and historicist interpretation of reality, it alone is history in the making and philosophy in the making, it alone is politics. ${ }^{30}$

As modern substitutes for the role played in history by talented and perceptive leaders, avant-garde political agents are assigned the duty to awaken and develop a

\footnotetext{
${ }^{30}$ Antonio Gramsci, Selections from the Prison Notebooks, ed. Quintin Hoare and Geoffrey Nowell Smith (London: International Publishers, 1971) 163.
} 
"national collective will" by introducing and adapting progressive universal ideas of justice to particular cultural and political circumstances. ${ }^{31}$ In his Philosophy of history Hegel had already emphasized the importance of particularly "clear-sighted" characters - what he called "world-historical individuals" - in understanding the needs of their time and taking initiatives to enact the political transformations they required. ${ }^{32}$ Those "thinking men" - Hegel stressed - had a special insight into what was "ripe for development"; they reflected it through their actions and words and contributed to dissolve the dilemmas of theoretical analysis in the practical immediacy of concrete political action. Gramsci - and Marx before him - considered however reductive analyzing the motion of leading social forces in history through a record of the actions of single individuals. Thus they proceeded to substitute it with an account of avantgarde agents which were abstract, collective and institutionally mediated (the workingclass, the party, organic intellectuals, civic associations) and which attempted to exercise political as well as cultural hegemony.

This conception of the avant-garde agent as a "modern prince" able to understand the motion of progressive social forces, organize them and invent strategies of political mobilization could be better understood in light of the analogy between artistic production and political activity and the emphasis placed on the "creative" moment of the process. The role of "avant-garde" agents is not exhausted in the application of a political program that promises to fulfil the needs of particular strata of society in a given historical situation. What is at stake is not merely providing a political platform that is supported by the greatest number of people and can claim to operate the necessary political changes. "Numbers", as Gramsci underlined, are "simply an instrumental value, giving a measure and a relation and nothing more". The difficult task is intervening at the level of that which is measured: "the effectiveness, and the expansive and persuasive capacity, of the opinions of a few individuals, the active minorities, the elites, the avant-gardes - i.e. their rationality, historicity or concrete functionality". 33

\footnotetext{
31 Ibid.

${ }^{32}$ See Georg Wilhelm Friedrich Hegel, The Philosophy of History (New York: Dover, 1956)., especially at (2) What means spirit uses to realize its Idea, section 35.

${ }^{33}$ Gramsci, Selections from the Prison Notebooks..
} 
The work of avant-garde political agents begins with the process of discovering the ideational centre of production of specific discourses on political agency, subjecting it to critical scrutiny and providing alternative visions on how interactions in the polity should be conceived. Avant-garde movements challenge the common-sense view that "all individual opinions have "exactly" equal weight" and argue that ideas and opinions do not spontaneously arise out of isolated cognitive processes but are rooted in specific social practices, which determine their political shape and must also be subjected to critical investigation. The institutional operationalization of ideas, "the counting of votes" is only "the final ceremony of a long process, in which it is precisely those who devote their best energies to the State and the nation (when such they are) who carry the greatest weight". 34

Considered from a broadly historical perspective the relevance of avant-garde political movements has consisted precisely in their ability to occupy the empty space between the critique of existing institutional practices and universal ideals on social justice with a concrete project for the emancipation of society. In a way similar to artistic avant-gardes, political ones have both acted as the critical conscience of a particular political tradition and made use of the cultural resources that it provided in order to bring into the public arena issues previously excluded from the agenda of institutional actors. Their political initiatives and discursive emphasis on the contrast between the formal recognition of universal principles of freedom and justice and the practical oppression of particular groups could be considered among the main artifices of expansion of the democratic public sphere. Due to the activity of political avantgardes what initially appeared odd or unacceptable to consolidated elites or was considered over-demanding by existent institutional standards progressively matured into a persistent popular request for modifying the scope and franchise of democratic citizenship.

Consider, for example, the way in which the formal recognition of the universal dignity of all human beings in the 1789 Declaration of the Rights of Man could go hand in hand with the exclusion of women or workers from participating in political decision-making. Or how one of the most fundamental assumptions of natural rights theory, the idea that "every man is born free", coexisted for almost three centuries with

\footnotetext{
${ }^{34}$ Ibid.
} 
the institution and practice of slavery. Few people today would question the right of women to vote or defend the legitimacy of holding slaves; few would have doubts condemning apartheid or racial discrimination. There tends to be universal agreement on the validity of certain moral standards. Yet not so long ago several of these issues were subject to heated debate even on the side of an educated public. Several universal principles of justice, now standard reference in international human rights circles, were introduced through difficult processes of domestic change. They only reached the global sphere in a second stage, once there were enough states to have recognized and implemented them. The merit of political avant-gardes consisted in their taking the lead to initiate a process of confrontation which made possible the introduction such principles within the domestic public. Only in a successive moment did international institutionalization start taking place.

Domestic structures have an essential role to play in the initial stages of protest campaigns, when people are familiarized with new repertoires of collective action and ideological innovation is introduced. Ordinary citizens must be able to understand the issues on the table, connect to them through local experiences, feel the need for political transformation. They ought to have a clear awareness of the limits of existent political practices in order to be eventually persuaded that alternative strategies are available and that things could go otherwise.

Consider for example the way in which women's movements initiated with claims for domestic changes within a small number of countries before such claims entered the international domain. Despite the existence of several suffrage organizations in the nineteenth century in several countries, a real international campaign was initiated only in 1904, when the International Women's Suffrage Association (IWSA) was founded. Between 1890 and 1930, the struggle had been only domestic, with several groups fighting within various states and national governments making concessions only on the face of strong pressure. Neither did such pressure emerge by itself. Political avant-garde movements led by characters such as Elizabeth Cady Stanton and Susan B. Anthony in the United States or Millicent Garrett Fawcett and Emmeline Pankhurst in England constantly engaged in domestic campaigns of "moral proselytism" trying to persuade other women 
about the importance of participating in public life and shift opinion in favour of their own cause. ${ }^{35}$

To make their voice heard, suffragettes engaged in several acts of civil disobedience: they chained themselves to fences, resorted to hunger strike, broke public buildings and refused to contribute their taxes. Only after such political avantgardes succeeded having key states modify their electoral laws, did norm modification reach a threshold point. Then a "cascade" effect would occur and allow for easier subsequent transformations in a greater number of states. In the case of women's suffrage, that threshold was reached in 1930 when twenty states (roughly one third of the total states system) had endorsed the claims of the movement. Once a number of key actors accepted such normative modifications, it was easier for domestic actors in other places to exercise pressure on their respective governments and introduce similar changes. Thus, while it took eighty years to the first twenty states to adopt women's suffrage, in the twenty years that followed forty-eight countries had adopted the norm. ${ }^{36}$

A similar dynamic has been observed with regard to some of the greatest movements for social reform during both the $19^{\text {th }}$ century (anti-slavery movement, workers' movement) and the $20^{\text {th }}$ century (anti-apartheid or anti-colonization movement). ${ }^{37}$ In all those cases the leading role for both raising consciousness on the exclusionary nature of specific political practices and creating political occasions for protesting and modifying them was played by domestic "avant-garde" movements: groups of committed intellectuals, social activists and enlightened political reformers without whom the democratic transformations we are all familiar with would have never occurred. The means through which these groups tried to exercise influence in the public, ranging from publishing political newspapers, to

\footnotetext{
${ }^{35}$ See Martha Finnemore and Kathryn Sikkink, "International Norm Dynamics and Political Change," International Organization 52, no. 4 (1998): 897.

${ }^{36}$ See Francisco O. Ramirez, Yasemin Soysal, and Suzanne Shanahan, "The Changing Logic of Political Citizenship: Cross-National Acquisition of Women's Suffrage Rights, 1890 to 1990," American Sociological Review 62, no. 5 (1997). A recent example of such "cascade" effect taking place is the ban on landmines. By May 1997 the number of states supporting the ban on anti-personnel land mines had reached 60, or approximately one-third of the total states in the system. After that, a "cascade occurred, and 124 states ratified the Ottawa land mine treaty within only 7 months. See Finnemore and Sikkink, "International Norm Dynamics and Political Change," 901.

37 See Neta C. Crawford, Argument and Change in World Politics : Ethics, Decolonization, and Humanitarian Intervention (Cambridge: Cambridge University Press, 2002).
} 
spreading pamphlets, to public protest or strike, to institutional pressures, might have differed as much as in the case of artistic avant-gardes, but the goal pursued by all was a similar one: progressively improving on the quality of the democratic sphere by increasing the accountability of political institutions.

Analogous processes may still be observed with regard to the internalization of human right norms in several authoritarian states, for example in Africa and Asia. $^{38}$ The most effective campaigns here have been those able to address domestic publics in a way that persuaded them about the moral relevance of civil and social rights. The process has witnessed various phases: in a first stage both domestic and non-governmental actors, linked through transnational advocacy networks, tried to exercise pressures on governments without the legitimacy of their claims being yet recognized. This is also the stage in which the ability of avant-gardes to connect to a domestic public seems to have been most crucial. It was necessary to mobilize as many resources as possible in order to signal governments internal dissatisfaction and denounce their lack of moral standards, however traditional channels of representation were missing. In the absence of conventional institutional resources, avant-garde actors could only recur to rational argumentation, persuasion and symbolic campaigns linking their narratives to familiar historical episodes of social protest in order to convince fellow-citizens about the importance of certain moral principles.

Where these campaigns were successful and obtained enough local support, governments started making rhetorical concessions. This opened the discursive space for further challenge on the side of critics thereby increasing the means available for putting more pressure. Questioned about their responsibility in rights' violations, governments responded by either denying its occurrence or by rejecting the charge that they represented a systematic phenomenon. At this point, however, the confrontation had become more detailed and parties recognized each other as valid interlocutors. This paved the way towards the definite internalization of human rights norms. Finally, once that process was over, specific states not only acted

\footnotetext{
${ }^{38}$ My discussion here is indebted to the discussions in Thomas Risse, "International Norms and Domestic Change: Arguing and Communicative Behavior in the Human Rights Area," Politics \& Society 27, no. 4 (1999), Thomas Risse, Stephen C. Ropp, and Kathryn Sikkink, eds., The Power of Human Rights: International Norms \& Domestic Change (Cambridge: Cambridge University Press, 1999).
} 
following principles they would have initially rejected but even perceived themselves as pioneers in the region, trying to persuade other states to follow their route and listen to the claims of domestic activists. In all those cases the behavior of states could not have been easily predicted at the outset without taking into account the way in which local avant-gardes intervened to modify their goals and selfperception.

\section{The meaning of a "cosmopolitan avant-garde"}

The struggle for inclusion in the polity of cosmopolitan imperatives should be considered in continuity with such historical efforts. Cosmopolitan discourses on global distributive equality could in fact be interpreted as one more political cause of expansion of the aims and scope of the polity, rendering it more sensitive to the concerns of subjects affected by deliberative processes from which they are territorially excluded and more responsive to ideals of global solidarity (rather than narrow selfinterest) within the international sphere. ${ }^{39}$ Applied to the cosmopolitan discourse, the concept of an "avant-garde movement" could be used to denote those political agents for whom the role of the state should not be limited to the protection of those who happen to share particular political boundaries, but ought to include in its franchise the interests of all those affected by its own policies or by the global policies that it contributes enforcing.

Local cosmopolitan avant-gardes could be involved in the processes of influencing decision-formation and jointly transforming the collective institutions to which the citizens of particular states owe the possibility of a fair coordination of their public activities. They would campaign for substantive equality between states in the international sphere and activate themselves to reform their respective legislative and judiciary systems. They would also try to change the various international institutions in charge of regulating global processes of production and distribution of goods (eg. the market), the modalities of knowledge sharing and transfer (eg. educational schemes, the protection of sciences, arts and culture), military cooperation, and so on.

\footnotetext{
${ }^{39}$ See Iris Marion Young, Inclusion and Democracy (Oxford Oxford University Press, 2002) 236-76. For one discussion on cosmopolitanism as inclusion see Max Pensky, "Two Cheers for Cosmopolitanism: Cosmopolitan Solidarity as Second-Order Inclusion," Journal of Social Philosophy 38, no. 1 (2007).
} 
A local cosmopolitan avant-garde could comprise both institutional political actors as well as those individuals, social movements or civil associations constituting what one we might call the sphere of "civil society". ${ }^{40}$ Among the former it is possible to list public officials, government representatives, various state agencies, political parties, and so on. To illustrate the latter one could to refer to the various associations and networks committed to particular civil or political causes such as the protection of the environment, migrants' organizations and workers' movements, the rights of minority-groups, anti-poverty campaigns or campaigns in favour of military disarmament. Through this broad characterization, we would capture both formal procedures of decision-making and decision enforcing and the more spontaneous forms of action in the public sphere that try to influence or reshape state-agenda in a way that reflects new democratic political imperatives.

The cosmopolitan avant-garde would be committed to a universal view of social justice, to promoting inclusion and solidarity with foreigners in the domestic sphere and to establishing non-aggressive and non-exploitative international political institutions based on ideas of cooperative sovereignty. It would perceive domestic and international issues as interdependent on both moral and pragmatic grounds. As far as the former is concerned, it would argue that no state could claim to be just and democratic if it discriminates among citizens and strangers in the distribution of protection and social benefits, if it promotes egoistic foreign policies or if it unilaterally abuses its bargaining power in the international sphere. From the perspective of the latter, it would maintain that the policies a particular government promotes or endorses at the international level, the way it responds to various global political and economic challenges have important consequences for the well-being of its own citizens, just as the kind of decisions authorized by the latter by means of elections or other mechanisms of accountability matter enormously to those who are territorially excluded by a particular deliberative sphere.

\footnotetext{
${ }^{40}$ For definitions and discussions on civil society, see Jean Cohen and Andrew Arato, Civil Society and Political Theory (Cambridge, MA: MIT Press, 1992), John S. Dryzek, Deliberative Democracy and Beyond - Liberals, Critics, Contestations (Oxford: Oxford University Press, 2002), John Keane, Global Civil Society? (Cambridge: Cambridge University Press, 2003).On the difficulty of including in a definition of civil society both social movements and civic associations see Sidney Tarrow, "Transnational Politics: Contention and Institutions in International Politics," Annual Review of Political Science 4, no. 1 (2001).
} 
Who might constitute the "cosmopolitan avant-garde"? A growing number of authors in recent years have documented the emergence and consolidation of various political groups and social movements aiming to raise public awareness and build transnational networks of protest against the negative externalities of neo-liberal globalization processes and in favour of more just and accountable international political institutions. ${ }^{41}$ Typically such networks include formal organizations (for example socialist, social-democratic and green political parties as well as trade unions) informal associations (groups campaigning on gender issues, religious or indigenous movements, land-workers and peasants' organizations) as well as various branches of international non-governmental associations (such as Oxfam, Amnesty International, Emergency and so on). ${ }^{42}$ Some of these organizations are not new, they have emerged during previous mobilization campaigns (for example during the 1968 students' and workers' protests or in support of decolonization movements in the Third world) and survived their temporary decline only to re-emerge and readapt their agenda to new political circumstances. ${ }^{43}$ Others constitute recently created groups targeting neo-liberal global economic institutions and advocating trans-national control over markets and a fair global distribution of resources. It is, for one example, the case of the French association ATTAC, now present in several European countries as well as North Africa, Latin America and Canada, founded in 1997 with the aim of promoting control over global economic transactions (ATTAC stands for Action for a Tobin Tax to Aid Citizens). ${ }^{44}$

Within the model of political association outlined in the previous chapter the role of the cosmopolitan avant-garde in transforming the polity in a way that reflects principles of international solidarity and global inclusion would appear to be crucial. On the one hand emphasizing its very existence already responds to the critique that cosmopolitan imperatives are unable to mobilize the citizens of a particular society on

\footnotetext{
41 See Donatella Della Porta, Hanspeter Kriesi, and Dieter Rucht, eds., Social Movements in a Globalizing World (London: MacMillan, 1999), Dryzek, Deliberative Democracy and Beyond - Liberals, Critics, Contestations, Margret Keck and Kathleen Sikkink, Activists Beyond Borders: Advocacy Networks in International Politics (Ithaca: Cornell University Press, 1998), Young, Inclusion and Democracy.

${ }^{42}$ See Keck and Sikkink, Activists Beyond Borders: Advocacy Networks in International Politics.

${ }^{43}$ Donatella Della Porta and Mario Diani, Social Movements: An Introduction (Oxford: Blackwell, 1999) 253.

${ }^{44}$ See Donatella Della Porta, Globalization from Below : Transnational Activists and Protest Networks (Minneapolis: University of Minnesota Press, 2006) 33.
} 
issues that elude their direct interests and immediate spheres of concern. It allows to show, for one, that the citizens of Italy, Germany or the US may, and in fact do, participate in mass mobilizations against, for example, neo-liberal and exploitative policies promoted by international financial institutions in Africa and Asia or against, say, forced intervention in the Middle East.

On the other hand, by focusing on the role of the cosmopolitan avant-garde in taking the lead to challenge the establishment of unfair rules of international interaction it is possible to respond to a second critique usually made to cosmopolitanism. This critique underlines its inadequate reliance on limited individual actions to bring about large-scale global political transformations and points out at the weaknesses of this perspective in resolving consequent collective action problems. ${ }^{45}$ Our emphasis on the cosmopolitan avant-garde shifts attention away from the charitable initiatives of individual citizens and focuses on the activity of collective political agents - both civil society and institutional ones - which act as intermediaries between ordinary citizens on the one hand and domestic and international structures on the other. Similarly to historical avant-gardes mobilizing for inclusion in the democratic sphere, their purpose is twofold: on the one hand to make the former (citizens) progressively more sensitive to public campaigns raising awareness on pressing global issues, and on the other to make the latter (institutions) more responsive to political claims that require a shift in the international policies of the state.

Consider, for example, the recent call from activists in Europe and the United States to boycott the products of multinational companies which make profits by employing cheap labour force - in some cases child labour - in particular areas of the Third World. Several campaigns of mobilization including the organization of public debates and sit-ins, propaganda and information campaigns, activist demonstrations at the outlets of Nike, Levis, Gap etc., have tried to raise public awareness on the labour

\footnotetext{
45 These are the kind of critiques typically attracted by beneficence-based approaches to global justice (for example Cullity, "International Aid and the Scope of Kindness.", Cullity, The Moral Demands of Affluence, Singer, "Famine, Affluence and Morality.", Singer, One World: The Ethics of Globalization, Peter Unger, Living High and Letting Die: Our Illusion of Innocence (Oxford: Oxford University Press, 1996).) For discussions, see the essays in William Aiken and Hugh LaFollette, eds., World Hunger and Moral Obligations (Englewood Cliffs: Prentice Hall, 1977), Peter Brown and Henry Shue, eds., Food Policy: The Responsibility of the United States in Life and Death Choices (New York: Free Press, 1977). See also Andrew Kuper, "Global Poverty Relief More Than Charity: Cosmopolitan Alternatives to The "Singer Solution"," Ethics and International Affairs 16, no. 1 (2002), Liam Murphy, "The Demands of Beneficence," Philosophy and Public Affairs 22, no. 4 (1993).
} 
policies of such multinational corporations abroad. In many US universities, student associations have organized rallies and educative events, occupied campus buildings, and threatened hunger strikes, in trying to put pressure on their university administrations to end contracts with sportswear companies responsible for paying manufactured workers abroad salaries which did not cover even minimal subsistence needs. ${ }^{46}$ These activities urged fellow-citizens to think about the ethical consequences of their preferences as consumers and to take their share of political responsibility in opposing exploitative practices promoted by multinational corporations. ${ }^{47}$

Consider, for another example, the pro-migrant campaigns of international networks of associations active in countries with restrictive immigration and asylum policies such as the members of the European Union, the United States or Australia. Building alliances between unionized workers, immigrants, refugees and simple militants these associations have organized international border blockades, planned actions of civil disobedience in check-points and coordinated information seminars on non-violent resistance to protest against the deportation of migrants, denounce the miserable conditions of detention camps and promote the extension of citizenship rights. The goal of such activist campaigns is not simply to target the institutions responsible for the unjust treatment of migrants at the border but also raise public awareness among fellow-citizens about the limits of a globalization, which only applies to the free movement of capital and goods but increases barriers among people.

These initiatives may of course attract criticism for being merely facade activities, unable to modify the structural conditions from which unjust globalization processes depend. It is certainly true that without the kind of structural institutional adjustments that only states can provide civil society actors would have limited options of change and perhaps obtain merely symbolic rewards. The activity of civic cosmopolitan agents relies on institutional guarantees for security, the provision of public goods and the creation of conditions under which oppositional groups may grow, develop and exercise pressures on institutions. In several South American countries, for example, global justice activists literally risk their life on a daily basis and alarming

\footnotetext{
${ }^{46}$ For several empirical discussions of trans-national protest-campaigns with national targets see Della Porta, Kriesi, and Rucht, eds., Social Movements in a Globalizing World. especially the paper by Doug Imig and Sidney Tarrow, at pp. 112-132.

${ }^{47}$ Iris Marion Young, "Responsibility and Global Labour Justice," The Journal of Political Philosophy 12 , no. 4 (2004).
} 
reports continue to arrive on trade union members, peasants or members of civic groups being killed or falling victim of paramilitary violence. ${ }^{48}$ In all these situations, the political empowerment of oppositional groups and a share of institutional representation in state decision-making would appear to be crucial. Connecting local struggles to trans-national networks of advocacy on global issues has proved to be one of the most successful strategies of mobilisation with this regard.

The environmental movement, whose agenda in the 1950s was entirely unknown, offers one example of effective avant-garde work linking global issues to local activism. By the end of the 1990s the movement had managed to establish itself as one of the most important trans-national networks and environmental issues are now firmly part of any electoral agenda in democratic states. One of the main factors contributing to its growth was the capacity to connect successfully an issue with potentially global impact such as the environment to the local struggles of several indigenous communities and peasant unions in South America and Asia. The high point in its mobilization campaigns was reached when Washington activists made contact with rubber tapper organizers and indigenous communities from Acre (Brazil) who had been fighting since 1975 to ensure land use rights and improve living conditions in the Amazonian rainforest. The former helped indigenous communities gain visibility for their struggles in the international domain by supplying them important information and access to international decision-making arenas, whereas the latter helped to show the Western public that tropical deforestation was more than a set of technical or biological issues and affected the living conditions of depredated peasants. Despite the subsequent assassination of Chico Mendes, the movement's leader, indigenous communities and international activists succeeded in exercising joint pressure on the Brazilian government and on World Bank representatives and obtained important results, later institutionalized through the newly created environmentalist Worker's Party Government of Acre. ${ }^{49}$

It is undeniable that in many countries, especially Western democracies, cosmopolitan avant-garde movements need more political cohesion, more clarity of purpose, more transparent mechanisms of accountability and greater ideological

\footnotetext{
${ }^{48}$ See on some of these issues Tom Mertes, "Grass-Roots Globalism," New Left Review 17 (2002), Emir Sader, "Beyond Civil Society," New Left Review 17 (2002).

${ }^{49}$ Keck and Sikkink, Activists Beyond Borders: Advocacy Networks in International Politics 128-49.
} 
awareness in order to be politically effective. They also need to be able to mobilize the larger public, in particular the working class and petty-bourgeoisie, which are likely to suffer more from the negative externalities of globalization processes but seem to react by either manifesting symptoms of political "disaffection" reactionary, populist and xenophobic policies. ${ }^{51}$ Here the need to come up with innovative projects linking the older modes of political participation, a reinvented role for the state as the major promoter of global reform and new discourses of global inclusion and solidarity would appear most urgent. Important examples of jointinitiatives from trade-union activists operating across borders, such as the long-standing cooperation between IG Metal in Germany and the Brazilian Metalworkers affiliated with CUT (Central Unica dos Trabalhadores), show that the use of global contacts to strengthen pressure on local governments and corporate organizations may be an effective strategy of combining the global and the local.

Clarifying how local civic and institutional agents should interact with each other and within trans-national networks, what degree of inclusion in the state cosmopolitan social movements should seek in order to make their claims more effective, and to what extent political parties should try to influence civic actors or involve them in electoral processes is a complex issue. An adequate answer to this puzzle would require a more case-by-case analysis taking into account the specificities of each political community, its tradition of social mobilization, its institutional past and prospects of reform and the ways its public culture has historically developed. ${ }^{52}$ The emergence of a 'cosmopolitan avant-garde' seeking to introduce global issues in the agenda of states and include global justice imperatives in the moral commitments of ordinary citizens is after all a recent phenomenon. The movement still needs to consolidate; the political and cultural features of its various components are to emerge more clearly, before avant-garde cosmopolitan principles are transformed into a fully

\footnotetext{
${ }^{50}$ See Offe, "Political Disaffection as an Outcome of Institutional Practices? Some Post-Tocquevillean Speculations.".

${ }^{51}$ Peter Mair, "Ruling the Void? The Hollowing of Western Democracy," New Left Review 42 (2006).

${ }^{52}$ This remark seems to be confirmed by the various strategies the global justice movement has chosen to pursue in different countries, with agents in the South of the world seeking active inclusion in state structures and introducing cosmopolitan political innovations by means of institutional reform (think of India, South Africa and several Latin American countries) and those in the global North recurring to more civil initiatives.
} 
coherent political alternative. At this stage of the process it would seem that the real interest of cosmopolitan avant-garde initiatives all over the world lies not so much in what the movement achieves but in what kind of alternative discourses on political responsibility it manages to create; not in what problems it resolves but in what issues it problematises. Without a widespread public awareness on the relevance of a more inclusive democratic sphere, without a massive assumption of political responsibility on the side of the citizens' of both affluent and poor states even those structural and institutional processes required to fight unjust globalization processes would lack the popular support needed to be established in the first place. It is the long-term issue of mass-political motivation rather than that of making concrete proposals in favour of cosmopolitan political structures (a question which relies on political practice as much as on normative argument) that our analysis of the role of the cosmopolitan avant-garde has mainly tried to address.

\section{Conclusion}

In this chapter, I have tried to explore the concept of an "avant-garde" movement in order to illustrate how the political community might be transformed in a way that reflects global justice imperatives. The idea of relying on existing civic and political agents who are already morally and politically sensitive to the cosmopolitan cause is meant to provide a response to critiques focusing on the absent motivational strength of cosmopolitanism and the possibility of constructing cosmopolitan initiatives in the absence of a global ethos of solidarity. Within the model of political association that I have outlined in the previous chapter the role of a cosmopolitan avant-garde in both educating the masses to alternative discourses of political agency in response to neoliberal globalization processes and in taking the lead to collectively enforce the political transformations required would appear to be crucial.

Indeed, the cosmopolitan avant-garde is rooted in a particular public sphere but it is also outward looking. One of its major assets is thus the ability to address political concerns in a way that makes sense to every participant of a shared political culture and use existing political structures and coercive mechanisms in a way that progressively seeks to expand the mechanisms of democratic accountability beyond those nationally 
available. It concentrates political efforts in both trying to increase citizens' awareness on pressing global issues and gather their consent in order to modify the imperatives guiding state-behaviour in the international sphere.

Of course the modes of action, the degree and type of involvement of the representatives of the "cosmopolitan avant-garde" might vary across places and according to the specific development of political campaigns for the promotion of cosmopolitan justice. They might also vary according to the specific features of the polity in which such attempts are taking place. One could expect the nature of protest campaigns in the United States to be quite different from that of India or Brazil, precisely because of the different historical development of public political interactions in each of these countries, and of the different degree of involvement and influence of these states in the international sphere. As a matter of political organization the cosmopolitan avant-garde has still a long way to go in homogenizing its objectives, building transparent international networks of coordination, sorting out the degree of inclusion and developing coherent proposals on which set of political structures would best accommodate the claims of global justice. However, the existence of groups of people committed to the cosmopolitan cause and putting pressures on their own states all over the world in order to modify their rules of cooperation proves that the realization of global justice is not just a pious wish; it is a reality in motion.

Justifying global cosmopolitanism from an ideal perspective is not enough to guarantee the feasibility of that project in non-ideal circumstances. Without a collective subject animating the general will in each particular community, without historically reflected goals, "cosmopolitan" ideals appear unhelpfully detached from local reality. At worse they end up nurturing political elitism, at best they construct moral utopias. Even a broadly shared moral consent on the necessity of global justice might not be able to substitute the political and cultural mechanisms of adaptation grounded on a particular collective self-understanding. It is as important to start a theory of global justice with ideal principles, as it is to conclude it with at least some idea on how to cope with the non-ideal dimension of politics. Worrying about the normative justification of global equality matters as much as thinking about concrete political processes of hegemony-construction, popular participation and power exercise which serve to realize abstract principles of distributive justice. Without cosmopolitanism at 
the level of principle, statist agency is morally indefensible. Without statism at the level of agency, cosmopolitan principles are politically unsustainable. The aim of this work has been to defend a statist cosmopolitan approach to global justice able to account for both principles and agency. 


\section{Bibliography}

Abizadeh, Arash. "Cooperation, Pervasive Impact, and Coercion: On the Scope (Not Site) of Distributive Justice." Philosophy \& Public Affairs 35, no. 4 (2007): 318-58.

Aiken, William, and Hugh LaFollette, eds. World Hunger and Moral Obligations. Englewood Cliffs: Prentice Hall, 1977.

Anderson, Perry, ed. Aesthetics and Politics. London: Verso, 1977.

Arendt, Hannah. Lectures on Kant's Political Philosophy. Edited by Ronald Beiner. Brighton: Harvester, 1982

Aristotle. Nicomachean Ethics. Translated by J. A. K. Thomson. London: Penguin, [unknown] 2004.

Barry, Brian. "Humanity and Justice in Global Perspective." In Contemporary Political Theory. An Anthology, edited by Robert E. Goodin and Philip Pettit, 52540. Oxford: Blackwell, 1982.

- "International Society from a Cosmopolitan Perspective." In International Society: Diverse Ethical Perspectives, edited by David Mapel; Terry Nardin, 14463, 1998.

—. The Liberal Theory of Justice. Oxford: Clarendon Press, 1973.

—_. "Rawls and the Search for Stability." Ethics 105, no. 4 (1995): 874-915.

- "Social Criticism and Political Philosophy." Philosophy and Public Affairs 19, no. 4 (1990): 360-73.

Beitz, Charles. "Cosmopolitan Ideals and National Sentiments." Journal of philosophy 80, no. 10 (1983): 591-600.

"Cosmopolitan Liberalism and the States System." In Political Structuring in Europe, edited by Chris Brown. London: Routledge, 1994.

_. "Cosmopolitanism and Global Justice." The Journal of Ethics, no. 9 (2005): $11-27$. 
- "Human Rights as Common Concern." American Political Science Review 95 (2001): 269-82.

- "Justice and International Relations." Philosophy and Public Affairs 4, no. 4 (1975): 360-89.

- Political Theory and International Relations. Princeton Princeton University Press, 1999.

—. "Rawls's Law of Peoples." Ethics 110, no. 4 (2000): 669-96.

Beitz, Charles R. "Does Global Inequality Matter?” Metaphilosophy 32, no. 1\&2 (2001): 95-112.

Benhabib, Seyla. Citizens, Residents and Aliens: Aliens, Residents, and Citizens. Cambridge: Cambridge University Press, 2004.

Bianchi, Lorenzo, ed. L'idea Di Cosmopolitismo. Circolazione E Metamorfosi. Naples: Liguori, 2002.

Bianchi, Lorenzo, and Alberto Postigliola, eds. Un "Progetto Filosofico Della Modernità". Naples: Liguori, 2000.

Birnholz, Alan C. "The Russian Avant-Garde and the Russian Tradition." Art Journal 32, no. 2 (1973): 146-49.

Blake, Michael. "Distributive Justice, State Coercion, and Autonomy." Philosophy \& Public Affairs 30, no. 3 (2001): 257-96.

Bobbio, Norberto. L'età Dei Diritti. Torino: Einaudi, 1990.

Bohmann, James, and Matthias Lutz-Bachmann, eds. Perpetual Peace: Essays on Kant's Cosmopolitan Ideal. Cambridge MA: MIT Press, 1997.

Braithwaite, John, and Peter Drahos. Global Business Regulation. New York: Cambridge University Press, 2000.

Brecht, Bertolt. “Against Georg Lukàsc.” New Left Review 84 (1974): 39-53.

- The Threepenny Opera. Translated by Desmond Vesey. New York: Grove Press, 1964.

Brighouse, Harry. “Civic Education and Liberal Legitimacy.” Ethics 108 (1998): 719-45.

. On Education. London: Routledge, 2006.

Brighouse, Harry, and Adam Swift. "Equality, Priority, and Positional Goods." Ethics 116 (2006): 471-97. 
Brock, Gillian. "Egalitarianism, Ideals and Cosmopolitan Justice." Philosophical Forum 36 (2005): 1-30.

Brown, Eric. "Hellenistic Cosmopolitanism." In A Companion to Ancient Philosophy, edited by Mary Louise Gill; Pierre Pellegrin, 549-58. Oxford: Blackwell, 2006.

Brown, Peter, and Henry Shue, eds. Food Policy: The Responsibility of the United States in Life and Death Choices. New York: Free Press, 1977.

Buchanan, Allen. "Rawls's Law of Peoples: Rules for a Vanished Westphalian World.” Ethics 110, no. 4 (2000): 697-721.

Buerger, Peter. Theory of the Avant-Garde. Manchester: Manchester University Press, 1984.

Bull, Hedley. The Anarchical Society: A Study of Order in World Politics. London Macmillan, 1977.

Callan, Eamonn. Creating Citizens: Political Education and Liberal Democracy. Oxford: Oxford University Press, 1997.

—_. "Liberal Legitimacy, Justice, and Civic Education." Ethics, no. 111 (2000): $141-55$.

Campbell, T. D. "Humanity before Justice." British Journal of Political Science 4, no. 1 (1974): 1-16.

Caney, Simon. "Cosmopolitan Justice and Equalizing Opportunities." Metaphilosophy 32, no. (1/2) (2001): 113-34.

"Cosmopolitan Justice and Institutional Design: An Egalitarian Liberal Conception of Global Justice.” Social Theory and Practice 32, no. 4 (2006): 725-56.

"Cosmopolitanism and the Law of Peoples." Journal of Political

Philosophy 10, no. 1 (2002): 95-123.

__. “International Distributive Justice.” Political Studies 49 (2001): 974-77.

- Justice Beyond Borders - a Global Political Theory. Oxford: Oxford University Press, 2005.

"Justice, Borders and the Cosmopolitan Ideal: A Reply to Two Critics." Journal of Global Ethics 3 (2007): 269-76.

Casal, Paula. "Why Sufficiency Is Not Enough.” Ethics 117 (2007): 296-326. 
Cavallar, Georg. The Rights of Strangers. Theories of International Hospitality, the Global Community and Political Justice since Victoria. . Aldershot: Ashgate, 2002.

Cohen, G. A. "Freedom, Justice and Capitalism." New Left Review 126 (1981): 3 16.

History, Labour, and Freedom. Themes from Marx. Oxford: Oxford University Press, 1989.

Cohen, Gerald A. "Facts and Principles." Philosophy \& Public Affairs 31, no. 3 (2003): 211-45.

—. "On the Currency of Egalitarian Justice." Ethics 99, no. 4 (1989): 906-44. Cohen, Jean, and Andrew Arato. Civil Society and Political Theory Cambridge, MA: MIT Press, 1992.

Cohen, Joshua, and Charles Sabel. "Extra Rempublicam Nulla Justitia?” Philosophy \& Public Affairs 34, no. 2 (2006): 147-75.

Constant, Benjamin. "The Liberty of the Ancients Compared with That of the Moderns." In Political Writings, edited by Biancamaria Fontana, 308-28.

Cambridge: Cambridge University Press, 1988 (1819).

Crawford, Neta C. Argument and Change in World Politics : Ethics, Decolonization, and Humanitarian Intervention. Cambridge: Cambridge University Press, 2002.

Crisp, Roger. "Equality, Priority, and Compassion.” Ethics 113 (2003): 745-63.

Cullity, Garret. "International Aid and the Scope of Kindness." Ethics 105, no. 1 (1994): $99-127$.

Cullity, Garrett. The Moral Demands of Affluence. Oxford: Oxford University Press, 2004.

Dahl, Robert. "Power as the Control of Behavior." In Power, edited by Steven Lukes, 94-143. New York: New York University Press, 1986.

Dancy, Jonathan. "Ethical Particularism and Morally Relevant Properties." Mind 92 (1983): 530-47.

Della Porta, Donatella. Globalization from Below : Transnational Activists and Protest Networks. Minneapolis: University of Minnesota Press, 2006.

Della Porta, Donatella, and Mario Diani. Social Movements : An Introduction. Oxford: Blackwell, 1999. 
Della Porta, Donatella, Hanspeter Kriesi, and Dieter Rucht, eds. Social Movements in a Globalizing World. London: MacMillan, 1999.

Diderot, Denis, and Jean Le Rond D'Alembert. Encyclopédie, Ou Dictionnaire Raisonné Des Sciences, Des Arts Et Des Métiers. 28 vols. Geneve; Paris; Neufchatel: Briasson and others, [1754-1772].

Dobson, Andrew. "Thick Cosmopolitanism.” Political Studies 54, no. 1 (2006): 165-84.

Dryzek, John S. Deliberative Democracy and Beyond - Liberals, Critics, Contestations. Oxford: Oxford University Press, 2002.

Egbert, Donald D. "The Idea Of "Avant-Garde" In Art and Politics.” The American Historical Review 78, no. 2 (1967): 339-66.

Elliott, John H. “The Decline of Spain.” Past and Present 20 (1961): 52-75.

Erskine, Toni. "Embedded Cosmopolitanism and the Case of War: Restraint, Discrimination and Overlapping Communities." Global Society 14, no. 4 (2000): 569-90.

Falk, Richard. Law in an Emerging Global Village: A Post-Westphalian Perspective. Ardsley: Transnational Publishers, 1998.

Farrelly, Colin. "Justice in Ideal Theory: A Refutation.” Political Studies 55 (2007): 844-64.

Feinberg, Joel. "Noncomparative Justice.” The Philosophical Review 83, no. 3 (1974): 297-338.

Finnemore, Martha, and Kathryn Sikkink. "International Norm Dynamics and Political Change.” International Organization 52, no. 4 (1998): 887-917.

Flikschuh, Katrin. "Justice or Virtue? Kant's Problem of "International Right"." 2006.

Kant and Modern Political Philosophy. Cambridge: Cambridge University Press, 2000.

Frankfurt, Harry. "Equality as a Moral Ideal.” Ethics 98, no. 1 (1987): 21-43.

Freeman, Samuel. "The Law of Peoples, Social Cooperation, Human Rights, and Distributive Justice" Social Philosophy and Policy 23, no. 01 (2006): 29-68.

Galston, William. Liberal Purposes: Goods, Virtues, and Diversity in the Liberal State. Cambridge: Cambridge University Press, 1991. 
Gerhardt, Volker, Rolf-Peter Horstmann, and Ralph Schumacher, eds. Kant Und Die Berliner Aufklaerung. Akten Des Ix. Internationalen Kant-Kongresses. Berlin:

Walter de Gruyter, 2001.

Gilabert, Pablo. "Global Justice and Poverty Relief in Nonideal Circumstances." Social Theory and Practice (2008): forthcoming.

Gilpin, Robert. Global Political Economy. Understanding the International Economic Order. Princeton: Princeton University Press, 2001.

Goodin, Robert E. "Enfranchising All Affected Interests, and Its Alternatives " Philosophy and Public Affairs 35, no. 1 (2007): 40-68.

_. "Political Ideals and Political Practice." British Journal of Political Science 25, no. 1 (1995): 37-56.

Protecting the Vulnerable: A Reanalysis of Our Social Responsibilities. Chicago, IL: University of Chicago Press, 1985.

Reasons for Welfare. The Political Theory of the Welfare State. Princeton: Princeton University Press, 1988.

_. "What Is So Special About Our Fellow Country-Men?" Ethics 98, no. 4 (1988): 666-83.

Gramsci, Antonio. Selections from the Prison Notebooks. Edited by Quintin Hoare and Geoffrey Nowell Smith. London: International Publishers, 1971.

Gutmann, Amy. Democratic Education. Princeton: Princeton University Press, 1987.

Habermas, Jurgen. The Inclusion of the Other: Studies in Political Theory Cambridge Mass.: MIT Press, 1998.

Habermas, Jürgen. The Postnational Constellation. Cambridge: Polity Press, 2001.

Hamilton, Earl J. “The Decline of Spain.” The Economic History Review 8, no. 2 (1938): 168-79.

—. "Imports of American Gold and Silver into Spain , 1503-1660." The Quarterly Journal of Economics 43, no. 3 (1929): 436-72.

Harrison, Charles, and Paul Wood, eds. Art in Theory 1815-1900: An Anthology of Changing Ideas. Oxford: Blackwell, 1998.

Havens, G. R. "Voltaire's Marginalia on the Pages of Rousseau." Ohio State University Studies 6, no. 15 (1933). 
Hayek:, Friedrich August. Law, Legislation and Liberty, the Mirage of Social Justice. Vol. 2. London: Routledge and Kegan 1976.

Hayward, Tim. "Global Justice and the Distribution of Natural Resources." Political Studies 54, no. 2 (2006): 349-69.

Heater, Derek. World Citizenship and Government : Cosmopolitan Ideas in the History of Western Political Thought. New York: St. Martin's Press, 1996.

Hegel, Georg Wilhelm Friedrich. The Philosophy of History. New York: Dover, 1956.

Held, David. Democracy and the Global Order: From the Modern State to Cosmopolitan Governance. Stanford: Stanford University Press, 1995.

Henson, Richard. "What Kant Might Have Said: Moral Worth and the Overdetermination of Dutiful Action." The Philosophical Review, no. 88 (1979): 3954.

Herman, Barbara. "On the Value of Acting from the Motive of Duty." The Philosophical Review 90, no. 3 (1981): 359-82.

Hirsch, Fred. Social Limits to Growth. Cambridge MA: Harvard University Press, 1976.

Hobbes, Thomas. The Leviathan. R. Tuck ed. New York: Cambridge University Press, 1991.

Hobsbawm, Eric. The Age of Empire. London: Weidenfeld and Nicolson, 1987.

- Behind the Times : The Decline and Fall of the Twentieth-Century AvantGardes. New York: Thames and Hudson, 1999.

Hobsbawm, Eric J. "Socialism and the Avantgarde in the Period of the Second International." Le Mouvement Social, no. 111 (1980): 189-99.

Hoeffe, Otfried. Kant's Cosmopolitan Theory. Cambridge: Cambridge University Press, 2006.

—

Hollis, Martin. "Positional Goods.” Philosophy 18 (1984): 97-110.

Hurka, Thomas. "The Justification of National Partiality." edited by Robert McKim and Jeff McMahan, 139-57. New York: Oxford University Press, 1997.

Huyssen, Andreas. After the Great Divide : Modernism, Mass Culture, Postmodernism. Bloomington: Indiana University Press, 1986. 
James, Aaron. "Constructing Justice for Existing Practice: Rawls and the Status Quo

" Philosohy and Public Affairs 33, no. 3 (2005): 281-316.

Jones, Charles. Global Justice : Defending Cosmopolitanism. Oxford: Oxford University Press, 2001.

Joseph S. Nye, Jr. “The Changing Nature of World Power." Political Science Quarterly 105, no. 2 (1990): 177-92.

Julius, A. J. “Nagel's Atlas.” Philosophy \& Public Affairs 34, no. 2 (2006): 176-92.

Kant, Immanuel. "An Answer to the Question: What Is Enlightenment." In Practical Philosophy, edited by Mary J. Gregor, 11-22. Cambridge: Cambridge University Press, [1784] 1996.

- "The Contest of Faculties." In Political Writings, edited by Hans Reiss, 176-90. Cambridge: Cambridge University Press, [1798] 1991.

. Critique of the Power of Judgment. Edited by Paul Guyer. Cambridge: Cambridge University Press, [1786] 2000.

—. "Idea for a Universal History in Cosmopolitan Perspective." edited by H. B. Nisbet. Cambridge: Cambridge University Press, [1784] 1991.

- "Idea for a Universal History with a Cosmopolitan Purpose." In Political Writings, edited by Hans Reiss, 41-53. Cambridge: Cambridge University Press, [1784] 1991.

- "The Metaphysics of Morals." In Practical Philosophy, edited by Mary Gregor, 353-604. Cambridge: Cambridge University Press, [1797] 1996.

— . "On the Common Saying: That May Be Correct in Theory, but Is of No Use in Practice." In Practical Philosophy, edited by Mary Gregor. Cambridge: Cambridge University Press, [1793] 1996.

- Religion within the Boundaries of Mere Reason and Other Writings. Cambridge: Cambridge University Press, [1793] 1998.

—. "Toward Perpetual Peace." In Practical Philosophy, edited by Mary Gregor, 311-52. Cambridge: Cambridge University Press, [1795] 1996.

Karagiannis, Nathalie, and Peter Wagner. "Towards a Theory of Synagonism." The Journal of Political Philosophy 13, no. 3 (2005): 235-62.

Keane, John. Global Civil Society? Cambridge: Cambridge University Press, 2003.

Keck, Margret, and Kathleen Sikkink. Activists Beyond Borders: Advocacy Networks in International Politics. Ithaca: Cornell University Press, 1998. 
Keohane, Robert, and Joseph S. Nye. Power and Interdependence. Boston: Little, Brown, 1977.

Kleingeld, Pauline. “Approaching Perpetual Peace: Kant's Defence of a League of States and His Ideal of a World Federation." European Journal of Philosophy 12 (2004): 304-25.

- "Kant's Cosmopolitan Law: World Citizenship for a Global Order." Kantian Review 2 (1998): 72-90.

—_. "Kant's Cosmopolitan Patriotism.” Kant Studien 94, no. 3 (2003): 299-316.

- "Six Varieties of Cosmopolitanism in Late Eighteenth-Century Germany." Journal of the History of Ideas 60, no. 3 (1999): 505-24.

Kramer, Hilton. "The Age of the Avant-Garde." Journal of Aesthetic Education 7, no. 2 (1973): 35-51.

Krassnof, Larry. "The Fact of Politics: History and Teleology in Kant." European Journal of Philosophy no. 2 (1994): 22-40.

Kuper, Andrew. "Global Poverty Relief More Than Charity: Cosmopolitan Alternatives to The "Singer Solution"." Ethics and International Affairs 16, no. 1 (2002): 107-20.

_. "Rawlsian Global Justice: Beyond the Law of Peoples to a Cosmopolitan Law of Persons." Political Theory 28, no. 5 (2000): 640-74.

Kymlicka, Will. Politics in the Vernacular - Nationalism, Multiculturalism, and Citizenship. Oxford: Oxford University Press, 2001.

Laughlin, Kevin Mac. Writing in Parts: Imitation and Exchange in NineteenthCentury Literature. Stanford: Stanford University Press, 1995.

Leibniz, Gottfried Wilhelm. New Essays on Human Understanding. Edited by Peter Remnant and Jonathan Bennett. Cambridge: Cambridge University Press, [1704] 1996.

Political Writings. Edited by Patrick Riley. Cambridge: Cambridge University Press, 1988.

Lenin, Vladimir I. What Is to Be Done? New York: International Publishers, [1902] 1929.

Lichtenberg, Judith. "Consuming Because Others Consume." Social Theory and Practice 22 (1996): 273-97. 
Lukes, Steven. Power : A Radical View. 2nd ed ed. Houndmills, Basingstoke, Hampshire : New York: Palgrave Macmillan, 2005.

Lütticken, Sven. "Secrecy and Publicity. Reactivating the Avant-Garde." New Left Review 17 (2002): 129-48.

Machiavelli, Niccolo. Discourses on Livy. Chicago: Chicago University Press, [1517] 1996.

Macintyre, Alasdair. Is Patriotism a Virtue?, Lindley Lecture. Lawrence: University of Kansas, 1984.

Mair, Peter. "Ruling the Void? The Hollowing of Western Democracy." New Left Review 42 (2006): 25-51.

Mandle, Jon. Global Justice. Cambridge: Polity Press, 2006.

Marchetti, Raffaele. Global Democracy: For and Against. Ethical, Institutional, and Social Perspectives on Political Inclusion. London: Routledge, 2008.

Mason, Andrew. "Just Constraints.” British Journal of Political Science 34 (2004): 251-68.

May, Gita. "Le Cosmopolite Ou Le Citoyen Du Monde; La Capitale Des Gaules Ou La Nouvelle Babylone by Louis-Charles Fougeret De Monbron." The French Review 45, no. 3 (1972): 737-38.

McDonough, Kevin, and Walter Feinberg. Citizenship and Education in LiberalDemocratic Societies - Teaching for Cosmopolitan Values and Collective Identities. Oxford: Oxford University Press, 2003.

Merker, Nicolao. L'illuminismo in Germania. L'età Di Lessing. Rome: Editori Riuniti, 1989.

Mertes, Tom. “Grass-Roots Globalism.” New Left Review 17 (2002): 101-10. Meyer, Lukas. "Liberal Cosmopolitanism and Moral Motivation." Global Society 14, no. 4 (2000): 631-47.

Micheli, Mario De. Le Avanguardie Artistiche Del Novecento. Milan: Feltrinelli, 1988.

Mill, John Stuart. Considerations on Representative Government. Edited by Geraint Williams. London: Everyman, [1861] 1993.

Miller, David. “Against Global Egalitarianism.” The Journal of Ethics 9 (2005): 5579. 
_. "Caney's 'International Distributive Justice': A Response.” Political Studies 50 (2002): 974-77.

. "Collective Responsibility and International Equality in the Law of Peoples." In Rawls's Law of Peoples, edited by Rex Martin; David Reidy, 191-205. Oxford: Blackwell, 2006.

—. "Holding Nations Responsible" Ethics 114, no. 2 (2004): 240-68.

- "Justice and Global Inequality." In Inequality, Globalization, and World Politics, edited by Andrew Hurrel; Ngaire Woods, 187-210. Oxford: Oxford University Press, 1999.

- "The Limits of Cosmopolitan Justice." In In International Society: Diverse Ethical Perspectives, edited by David Mapel; Terry Nardin. Princeton: Princeton University Press, 1998.

Press, 2007.

National Responsibility and Global Justice. Oxford: Oxford University . On Nationality. Oxford: Oxford University Press, 1997. Miller, Richard. "Cosmopolitanism and Its Limits." Theoria (2004).

Moellendorf, Darrel. Cosmopolitan Justice Boulder, Colo.: Westview Press, 2002.

Montbron, Fougeret de. Le Cosmopolite Ou Citoyen Du Monde. Edited by Raymond Trousson. Paris: Ducros, [1750] 1970.

Moore, Margaret. The Ethics of Nationalism Oxford: Oxford University Press, 2001.

Morgenthau, Hans. Politics among Nations: The Struggle for Power and Peace. 2nd ed. New York Alfred Knopf, 1959.

Murphy, Liam. "The Demands of Beneficence.” Philosohy and Public Affairs 22, no. 4 (1993): 267-92.

Nadeau, Maurice. The History of Surrealism. Cambridge MA: Belknap Press, 1989.

Nagel, Thomas. "The Problem of Global Justice." Philosophy \& Public Affairs 33, no. 2 (2005): 113-47.

Narveson, Jan. "Is World Poverty a Moral Problem for the Wealthy?" Journal of ethics 8, no. 4 (2005): 397-408.

—. "Welfare and Wealth, Poverty and Justice in Today's World." Journal of ethics 8, no. 4 (2005): 305-48. 
Nozick, Robert. Anarchy, State, and Utopia. Oxford: Blackwell, 1974.

Nussbaum, Martha. Frontiers of Justice. Cambridge (MA): Harvard University Press, 2006.

, ed. For Love of One Country? Boston: Beacon Press, 2002.

Nussbaum, Martha C. Cultivating Humanity: A Classical Defense of Reform in Liberal Education. Cambridge: Harvard University Press, 1997.

_. "Kant and Stoic Cosmopolitanism." The Journal of Political Philosophy 5, no. 1 (1997): 1-25.

O'Neill, Onora. "Abstraction, Idealization and Ideology in Ethics." In Moral Philosophy and Contemporary Problems, edited by J.D.G. Evans, 55-69. Cambridge: Cambridge University Press, 1987.

—_. "Agents of Justice." Metaphilosophy 32, no. 1/2 (2001): 180-95.

—. Bounds of Justice. Cambridge: Cambridge University Press, 2000.

—_. "The Dark Side of Human Rights." International Affairs 81, no. 427-39 (2005).

- Towards Justice and Virtue: A Constructivist Account of Practical Reasoning. Cambridge: Cambridge University Press, 1996.

O’Neill, Onora. Bounds of Justice. Cambridge: Cambridge University Press, 2000.

Offe, Claus. "Political Disaffection as an Outcome of Institutional Practices? Some Post-Tocquevillean Speculations." In Political Disaffection in Contemporary

Democracies. Social Capital, Institutions and Politics., edited by T. Mariano and G. R. Montero, 23-45. London: Routledge, 2006.

Parfit, Derek. "Equality and Priority.” Ratio X (1997): 202-21.

Pensky, Max. "Two Cheers for Cosmopolitanism: Cosmopolitan Solidarity as Second-Order Inclusion.” Journal of social philosophy 38, no. 1 (2007): 165-84.

Pettit, Philip. Republicanism: A Theory of Freedom and Government Oxford: Oxford University Press, 1999.

Pevnick, Ryan. "Political Coercion and the Scope of Distributive Justice." Political Studies 56 (2008): 399-413.

Phillips, Michael. "Reflections on the Transition from Ideal to Non-Ideal Theory." Noûs 19 (1985): 551-70. 
Pieri, Georges. "Raison Et Cosmopolitisme Au Xviiie Siècle." In L'idea Di Cosmopolitismo. Circolazione E Metamorfosi, edited by Lorenzo Bianchi, 357-64. Naples: Liguori, 2002.

Plato. The Collected Dialogues of Plato Including the Letters. Edited by Huntingon Cairns, Hamilton, Edith. Princeton: Princeton University Press, 1961

Pogge, Thomas. "Do Rawls's Two Theories of Justice Fit Together?” In Rawls's Law of Peoples, edited by Rex Martin and David Reidy. Oxford: Blackwell, 2006.

—_. "Real World Justice." The Journal of Ethics 9 (2005): 25-53.

—. Realizing Rawls. Ithaca Cornell University Press, 1989.

—. World Poverty and Human Rights. Cambridge: Polity Press, 2002.

Pogge, Thomas W. “Cosmopolitanism and Sovereignty.” Ethics 103, no. 1 (1992): 48-75.

—. "An Egalitarian Law of Peoples." Philosophy and Public Affairs 23, no. 3 (1994): 155-224.

Ramirez, Francisco O., Yasemin Soysal, and Suzanne Shanahan. "The Changing Logic of Political Citizenship: Cross-National Acquisition of Women's Suffrage Rights, 1890 to 1990." American Sociological Review 62, no. 5 (1997): 735-45.

Rawls, John. "Kantian Constructivism in Moral Theory." The Journal of Philosophy 77, no. 9 (1980): 515-72.

—. The Law of Peoples. Cambridge Mass: Harvard University Press, 1999.

_. Political Liberalism. New York: Columbia University Press,, 1993.

—. "The Sense of Justice." The Philosophical Review 72, no. 3 (1963): 281305.

A Theory of Justice. Rev. ed. Cambridge, Mass.: Belknap Press of Harvard University Press, 1999.

Raynal, Guillaume-Thomas. Histoire Des Deux Indes. Paris: La Découverte, [1781] 1980.

Reidy, David A. "Rawls on International Justice, A. Defense.” Political Theory 32, no. 3 (2004): 291-319.

Richards, David A. J. "International Distributive Justice." In Ethics, Economics, and the Law, Nomos Xxiv, edited by J. Roland Pennock and John W. Chapman, 275-99. New York:: New York University Press, 1982. 
—. A Theory of Reasons for Action. Oxford Clarendon Press, 1971.

Risse, Mathias. "Do We Owe the Global Poor Assistance or Rectification?" Ethics \& International Affairs 19, no. 1 (2005): 9-18.

" "How Does the Global Order Harm the Poor? ." Philosophy and Public Affairs 33, no. 4 (2005): 349-76.

98.

."What to Say About the State." Social Theory and Practice 32 (2006): 671-

. "What We Owe to the Global Poor." Journal of Ethics 9 (2005): 81-117.

Risse, Thomas. "International Norms and Domestic Change: Arguing and Communicative Behavior in the Human Rights Area." Politics \& Society 27, no. 4 (1999): 529-59.

Risse, Thomas, Stephen C. Ropp, and Kathryn Sikkink, eds. The Power of Human Rights: International Norms \& Domestic Change. Cambridge: Cambridge University Press, 1999.

Robeyns, Ingrid. "Ideal Theory in Theory and Practice." Social Theory and Practice (2008): forthcoming.

Robinet, André. “G. W. Leibniz: L'esprit Cosmopolitique Jusqu'à La Lettre.” edited by Lorenzo Bianchi, 5-26. Naples: Liguori, 2002.

Rodrik, Dani, ed. In Search of Prosperity: Analytical Narratives on Economic Growth. Princeton: Princeton University Press, 2003.

Rousseau, Jean-Jacques. Emile. Translated by Barbara Foxley. Charleston: Biblio Bazaar, [1762] 2006.

Rousseau, Jean Jacques. "Considerations on the Government of Poland." In The Social Contract and Other Later Political Writings, edited by Victor Gourevitch, 177-260. Cambridge: Cambridge University Press, [1772] 1997.

The Discourses and Other Early Political Writings. Translated by V. Gourevitch. Cambridge: Cambridge University Press, [1775] 1997.

_ . "Of the Social Contract." In The Social Contract and Other Later Political Writings, edited by Victor Gourevitch, 39-161. Cambridge: Cambridge University Press, [1762] 1997.

Rousseau, Jean Jacques “Abstract and Judgement of Saint Pierre's Project of Perpetual Peace.” In Rousseau on International Relations, edited by S. Hoffman; D. Fidler. Oxford: Clarendon Press, [1756] 1991. 
Sader, Emir. "Beyond Civil Society.” New Left Review 17 (2002): 87-99.

Sangiovanni, Andrea. "Global Justice, Reciprocity, and the State" Philosophy \& Public Affairs 35, no. 1 (2007): 3-39.

- "Justice and the Priority of Politics to Morality." The Journal of Political Philosophy 16, no. 2 (2008): 137-64.

Scanlon, Thomas. "Preference and Urgency." The Journal of Philosophy 72, no. 19 (1975): 655-69.

Scanlon, Thomas M. "Rawls' Theory of Justice." In Reading Rawls. Critical Studies on Rawls' a Theory of Justice, edited by Norman Daniels, 169-205. New York:

Basic Books, 1975.

Scheffler, Samuel. Boundaries and Allegiances: Problems of Justice and Responsibility in Liberal Thought. Oxford: Oxford University Press, 2003.

Schiller, Friedrich Von. Letters Upon the Aesthetic Education of Man. Montana: Kessinger Publishers, [1795] 2004.

Schlereth, Thomas J. The Cosmopolitan Ideal in Enlightenment Thought. Notre Dame: University of Notre Dame Press, 1977.

Schwartzman, Lisa H. "Abstraction, Idealization, and Oppression." Metaphilosophy 37, no. 5 (2006): 565-88.

Sen, Amartya. Inequality Reexamined. Oxford: Oxford University Press, 1995.

—. "Justice Accross Borders." In Global Justice and Transnational Politics, edited by Pablo De Greiff and Ciaran Cronin, 35-37. Cambridge (MA): Mit Press, 2002.

- Poverty and Famines: An Essay on Entitlement and Deprivation. Oxford: Oxford University Press, 1983.

—. "A Sociological Approach to the Measurement of Poverty: A Reply to Professor Peter Townsend." Oxford Economic Papers 37, no. 4 (1985): 669-76.

- "What Do We Want from a Theory of Justice?" The journal of philosophy 103, no. 5 (2006): 215-38.

Shaffer, Gregory. "Power, Governance and the Wto: A Comparative Institutional Approach." In Power in Global Governance, edited by Michael Barnett and Raymond Duvall, 130-61. Cambridge: Cambridge University Press, 2005.

Shue, Henry. Basic Rights: Subsistence, Affluence, and U.S. Foreign Policy. Princeton: Princeton University Press, 1996. 
—. "Thickening Convergence: Human Rights and Cultural Diversity." In The Ethics of Assistance: Morality and the Distant Needy, edited by Deen K. Chatterjee. Cambridge: Cambridge University Press, 2004.

Simon, Henri de Saint. Selected Writings on Science, Industry and Social

Organization. Translated by Keith Taylor. London: Croom Helm, [1825] 1975.

Singer, Peter. "Famine, Affluence and Morality." Philosophy \& Public Affairs 1, no. 3 (1972): 229-43.

One World: The Ethics of Globalization. New Haven Yale University Press, 2002.

— . "Outsiders, Our Obligations to Those Beyond Our Borders." In The Ethics of Assistance: Morality and the Distance Needy, edited by Deen K. Chatterjee, 1132. Cambridge: Cambridge University Press, 2004.

Smith, Adam. The Wealth of Nations: Iv-V. Edited by Andrew Skinner. London: Penguin, [1776-1783] 1999.

Steinberg, Richard H. "In the Shadow of Law or Power? Consensus-Based Bargaining and Outcomes in the Gatt/Wto." International Organization 2, no. 56 (2002): 339-74.

Stemplowska, Zofia. "What's Ideal About Ideal Theory?" Social Theory and Practice (2008): forthcoming.

Stiglitz, Joseph, and Andrew Charleton. Fair Trade for All. Oxford: Oxford University Press, 2005.

Stiglitz, Joseph E. Globalization and Its Discontents. London: Penguin, 2002. Stocker, Michael. "The Schizophrenia of Modern Ethical Theories." The Journal of Philosophy 73, no. 14 (1976): 453-66.

Swift, Adam. "The Value of Philosophy in Non-Ideal Circumstances." Social Theory and Practice (2008): forthcoming.

Tan, Kok-Chor. Justice without Borders : Cosmopolitanism, Nationalism, and Patriotism. Cambridge: Cambridge University Press, 2004.

Tarrow, Sidney. "Transnational Politics: Contention and Institutions in International Politics." Annual Review of Political Science 4, no. 1 (2001): 1-20.

Therborn, Göran. "Entangled Modernities." European Journal of Social Theory 6 (2003): 293-305.

Townsend, Peter. Poverty in the United Kingdom: A Survey of Household Resources and Standards of Living. Berkeley: University of California Press, 1979. 
Unger, Peter. Living High and Letting Die: Our Illusion of Innocence. Oxford: Oxford University Press, 1996.

Valentini, Laura. "On the Apparent Paradox of Ideal Theory." Journal of Political Philosophy (200?): forthcoming.

Voltaire, François Marie Arouet. Le Siecle De Louis Xiv. Paris Garnier-Flammarion, [1774] 1966.

- Political Writings. Translated by D. Williams. Cambridge: Cambridge University Press, [1752] 1994.

Waldron, Jeremy. "What Is Cosmopolitan?" Journal of Political Philosophy 8, no. 2 (2000): 227-43.

- ed. Nonsense Upon Stilts': Bentham, Burke, and Marx on the Rights of Man. London: Methuen, 1987.

Walzer, Michael. Interpretation and Social Criticism. Cambridge, Mass.: Harvard University Press, 1987.

_. "The Moral Standing of States: A Response to Four Critiques." Philosophy and Public Affairs 9, no. 3 (1980): 209-29.

. Obligations: Essays on Disobedience, War, and Citizenship. Cambridge MA: Harvard University Press, 1970.

- Spheres of Justice: A Defence of Pluralism and Equality. Oxford Robertson, 1983.

Weber, Max. Economy and Society: An Outline of Interpretive Sociology. Berkeley: University of California Press, [1914] 1978.

Wenar, Leif. “The Legitimacy of Peoples.” In Global Justice and Transnational Politics, edited by Pablo De Greiff and Ciaran Cronin, 37-52. Cambridge (MA): Mit Press, 2002.

Williams, Howard. Kant's Critique of Hobbes. Cardiff: University of Wales Press, 2003.

—. Kant's Political Philosophy. Oxford: Blackwell, 1983.

Young, Iris Marion. Inclusion and Democracy. Oxford Oxford University Press, 2002.

- "Responsibility and Global Labour Justice." The Journal of Political Philosophy 12, no. 4 (2004): 365-88. 
